\title{
Fracture propagation and reservoir permeability in limestone-marl alternations of the Jurassic Blue Lias Formation (Bristol Channel Basin, UK)
}

\author{
Dissertation \\ zur Erlangung des mathematisch-naturwissenschaftlichen Doktorgrades \\ "Doctor rerum naturalium" \\ der Georg-August-Universität Göttingen \\ im Promotionsprogramm Geowissenschaften \\ der Georg-August University School of Science (GAUSS)
}

vorgelegt von

Filiz Afșar

aus Vorwerk

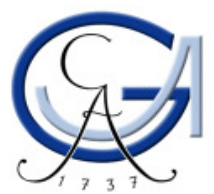

Göttingen 2014 


\section{Betreuungsausschuss}

Prof. Dr. Sonja L. Philipp

Abteilung Strukturgeologie und Geodynamik

Geowissenschaftliches Zentrum der Georg-August-Universität Göttingen

Prof. Dr. Hildegard Westphal

Abteilung Biogeochemie und Geologie

Leibniz-Zentrum für Marine Tropenökologie

\section{Mitglieder der Prüfungskommission}

Referentin:

Prof. Dr. Sonja L. Philipp

Abteilung Strukturgeologie und Geodynamik

Geowissenschaftliches Zentrum der Georg-August-Universität Göttingen

Korreferentin:

Prof. Dr. Hildegard Westphal

Abteilung Biogeochemie und Geologie

Leibniz-Zentrum für Marine Tropenökologie

\section{Weitere Mitglieder der Prüfungskommission}

Prof. Dr. Jonas Kley

Abteilung Strukturgeologie und Geodynamik

Geowissenschaftliches Zentrum der Georg-August-Universität Göttingen

PD Frank Wiese

Abteilung Geobiologie

Geowissenschaftliches Zentrum der Georg-August-Universität Göttingen

Dr. David Hindle

Abteilung Strukturgeologie und Geodynamik

Geowissenschaftliches Zentrum der Georg-August-Universität Göttingen

Dr. Elco Luijendijk

Abteilung Strukturgeologie und Geodynamik

Geowissenschaftliches Zentrum der Georg-August-Universität Göttingen

\section{Tag der mündlichen Prüfung}

12.01 .2015 
'Progress is impossible without change, and those who cannot change their minds cannot change anything'.

Georg Bernard Shaw (1856-1950) 
In memory of our dear friend and colleague Johannes "Yo" Lindtke (10.04.1978 - 28.04.2011) who left us much too early. His great humanity, optimism, enthusiasm and passion for geology has always been inspiring, motivating and supporting in good and in hard times.

He will always remain on our hearts. 


\section{-Abstract-}

In layered reservoirs characterised by low matrix permeability, fracture networks control the main fluid flow paths. In limestone-marl alternations, however, the vertical fractureassociated permeability varies considerably between distinct layers. Within a succession, various sedimentological features (e.g. sedimentary layering or diagenetic bedding) lead to contrasting rock properties and thus may act as stress barriers. Stress barriers such as lithological contacts or thick marl layers can prevent the fracture propagation in layered rocks, making the prediction of potential fluid flow paths in such successions even more complicated. To improve the prediction of potential fluid flow path, it is crucial to find several layers without stress barriers, which act mechanically as a single unit ('mechanical unit'). The aim of this doctoral study is to assess the impact of sedimentological and diagenetic features and petrophysical properties on vertical fracture propagation in limestone-marl alternations of the Jurassic Blue Lias Formation (Bristol Channel Basin, United Kingdom), in order to define different kinds of stress barriers and mechanical units. For this purpose, six sections characterised by different morphological variations (e.g. from limestone-dominated to marldominated) were comprehensively investigated combining sedimentological (e.g. field observations, thin section petrography, scanning electron microscopy, $\mathrm{CaCO}_{3}$ - and $\mathrm{C}_{\text {org- }}$ measurements), quantitative structural geological (e.g. characterisation of fracture networks) and petrophysical data (e.g. tensile and compressive strength-, rock hardness- and porositymeasurements). Concerning the quantitative structural geological approach, more than 4000 fractures were traced over several layers along a $15 \mathrm{~m}$ scan-line using a modified scan-line method (i.e. a combination of scan-line and window sampling).

It is generally assumed that the spacing between tension fractures increases and the fracture density decreases with increasing bed thicknesses. This study revealed, however, that in the respective beds of these alternations this relationship is only limitedly applicable and can only be applied in cases of beds with laterally planar surfaces (i.e. well-bedded limestones). Even in beds with the same thickness the fracture spacing varies significantly in beds with irregular surfaces (i.e. semi-nodular limestones). That means fractures are unregularly spaced in seminodular limestones and more regularly spaced in well-bedded limestones. Furthermore, wellbedded limestones in the successions are generally characterised by higher percentages of stratabound fractures $(57 \%)$, while semi-nodular limestones show higher percentages of nonstratabound fractures $(67 \%)$. Not only is the fracture distribution in single beds crucial for the 
fracture propagation in layered rocks, but also stress barriers such as lithological contacts, thicknesses and heterogeneities within marl layers inhibit fracture propagation, as well. Stress barriers were identified based on vertical fracture termination at and crossing through lithological contacts and vertical fracture extension through layers (stratabound vs. nonstratabound fractures). Since not all lithological contacts prevent the fracture propagation in layered rock, the term was only used in this doctoral project for $50 \%$ of fracture terminations at these contacts (i.e. 'mechanical interfaces'). In addition thick marl layers $(>0.20 \mathrm{~m})$ bounded by mechanical interfaces and less than $50 \%$ non-stratabound fractures are defined as 'mechanical buffer'. Given the high heterogeneity of the Blue Lias Formation in fracture distribution also the impact of diagenesis varies significantly from section to section. For instance, three subsections in Wales were studied in detail, despite of their close vicinity and relative contemporaneous time, all three subsections reveal different sedimentological and diagenetic features on metre to micrometre scales (from early lithified over physically compacted) and are all characterised by dissimilar patterns of fracture terminating at and crossing through lithological contacts and fracture extension (e.g. percentages of nonstratabound fractures) within beds. Lithological contacts in diagenetic influenced successions are more gradual and hence are no mechanical interfaces, if additionally the contrast of $\mathrm{CaCO}_{3}$ contents between limestones and marls is low the succession can be defined as a mechanical unit which promotes the fracture propagation.

The prediction of fracture network connectivity is difficult in lithological heterogeneous limestone-marl alternations such as the Blue Lias Formation with high heterogeneity in fracture distribution, different impact of diagenesis and effect of different stress barriers. This is particularly problematic for the characterisation of fracture networks and its application in outcrop analogue studies, which are commonly used to predict main fluid flow paths in such systems. The findings of this study are crucial to improve the quantification of fracture distribution and propagation in heterogeneous rock successions and, consequently, to refine definitions of mechanical units, being an important prerequisite for the prediction of fractureassociated permeability and fluid flow models. 


\section{-Zusammenfassung-}

In geschichteten Reservoiren mit geringer Matrix-Permeabilität kontrollieren überwiegend Bruchsysteme den Fluidtransport. In Kalk-Mergel-Wechselfolgen sind allerdings die vertikale Kluftausbreitung sowie die Vernetzung der Kluftsysteme zwischen den unterschiedlichen Schichten sehr variabel, was schließlich die Permeabilität in diesen bruchkontrollierten Reservoiren erheblich beeinflusst. Innerhalb einer Schichtfolge führen diverse sedimentologische Merkmale (z.B. sedimentäre Schichtung und diagenetische Bankung) zu kontrastreichen Gesteinseigenschaften und wirken somit als Spannungsbarrieren. Spannungsbarrieren, wie beispielsweise lithologische Kontakte oder mächtige Mergellagen, können die Kluftausbreitung in geschichteten Gesteinen ebenfalls verhindern und erschweren zusätzlich die Vorhersage potentieller Fluidwege. Aufgrund dessen ist es entscheidend Schichten, die sich mechanisch einheitlich verhalten (,mechanische Einheit“) zu finden. Das Ziel dieser Doktorarbeit ist, den Einfluss von sedimentologischen und diagenetischen Merkmalen und petrophysikalischen Eigenschaften vertikaler Kluftausbreitung in Kalk-Mergel-Wechselfolgen der Jurassischen Blue Lias Formation (Bristol Channel Becken, Großbritannien) abzuschätzen, um verschiedenartige Spannungsbarrieren und mechanische Einheiten zu definieren. $\mathrm{Zu}$ diesem Zweck wurden sechs Profile untersucht, welche sich durch unterschiedliche morphologische Variationen auszeichnen (d.h. von kalkdominiert zu mergeldominiert). Die Untersuchungen umfassen Kombinationen aus sedimentologischer (z.B. Geländeuntersuchungen, Dünnschliffpetrografie, Rasterelektronenmikroskopie, $\mathrm{CaCO}_{3}$ -

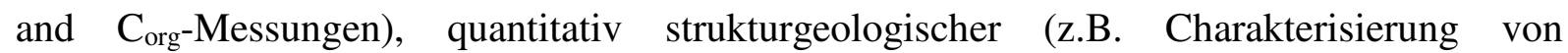
Kluftsystemen) sowie petrophysikalischer Daten (z.B. Spaltzug- und Druckfestigkeits-, Rückprallhärte- und Porositäts-Messungen). Im Rahmen der quantitativen strukturgeologischen Untersuchungen wurden unter Verwendung einer modifizierten Scanline Methode (Durchführung einer flächengestützten Kluftanalyse) über 4000 schichtübergreifende Klüfte betrachtet.

Generell wird angenommen, dass der Kluftabstand mit zunehmender Bankmächtigkeit zunimmt und die Kluftdichte dementsprechend abnimmt. Diese Studie zeigt jedoch, dass dieser Zusammenhang nur eingeschränkt auf Kalkbänke dieser Abfolgen anwendbar ist und nur auf Schichten mit lateral planaren Oberflächen (wohlgebankte Kalkbänke) übertragen werden kann. Bei Bänken gleicher Mächtigkeit mit allerdings irregulären Oberflächen (semiknollige Kalkbänke) variieren die Kluftabstände innerhalb dieser Bänke beträchtlich. 
Das bedeutet, die Kluftabstände sind in semiknolligen Kalkbänken eher unregelmäßig wohingegen die Abstände in wohlgebankten Bänken eher regelmäßig sind. Des Weiteren sind in wohlgebankten Kalken ein höherer prozentualer Anteil von schichtgebundenen Klüften (57 $\%$ ) ausgebildet. Dagegen sind in semiknolligen Kalken ein höherer Anteil nicht-schichtgebundener Klüfte ausgebildet (67\%). Entscheidend für die Kluftausbreitung in geschichteten Gesteinen ist nicht nur die Kluftverteilung der einzelnen Bänke, sondern auch verschiedenartige Spannungsbarrieren, wie beispielsweise lithologische Kontakte, Mächtigkeiten und Heterogenitäten von Mergeln hemmen die Kluftausbreitung. Anhand der vertikalen Kluftstoppung an lithologischen Kontakten und vertikale Kluftausbreitung durch Schichten wurden Spannungsbarrieren identifiziert (schichtgebundene vs. nicht-schichtgebundene Klüfte). Da nicht alle lithologische Kontakte die Ausbreitung von Klüften in geschichteten Gesteinen verhindern, wurde in dieser Studie der Terminus für $50 \%$ Kluftstoppung an diesen Kontakten verwendet (,mechanische Grenzflächen“). Zusätzlich wurden bestimmte Mergellagen, die $>0.20 \mathrm{~m}$ mächtig sind, durch mechanische Grenzflächen begrenzt sind und weniger als $50 \%$ nicht-schichtgebundene Klüfte beinhalten, als „mechanische Puffer“ definiert. Die Charakterisierung des Kluftsystems wird neben der vorherrschenden stark heterogenen Kluftverteilung in der Blue Lias Formation, auch durch eine signifikante Variation des Diagenese-Einflusses von Abschnitt zu Abschnitt erschwert. Beispielsweise wurden in Wales drei Teilprofile genauestens untersucht, welche trotz ihrer räumlich nahen Lage und relativ zeitgleichen Entstehung unterschiedliche sedimentologische und diagenetische Merkmale in Meter- bis Mikrometer-Skalen aufweisen (von früh lithifiziert bis physikalisch kompaktierte Abfolgen). Darüber hinaus sind diese durch unterschiedliche Muster der Kluftstoppung an Kontakten und Kluftausbreitung innerhalb der Bänke charakterisiert. Lithologische Kontakte in diagenetisch beeinflussten Abfolgen sind tendenziell eher graduell und somit keine mechanischen Grenzflächen. Wenn zusätzlich der Unterschied zwischen den $\mathrm{CaCO}_{3}$-Konzentrationen zwischen Kalken und Mergeln niedrig ist, kann die Abfolge als eine mechanische Einheit definiert werden, welches die Kluftausbreitung begünstigen würde.

Die Vorhersage der Konnektivität von Kluftnetzwerken ist in lithologisch heterogenen Kalk-Mergel-Wechselfolgen, wie die in der Blue Lias Formation, aufgrund unterschiedlicher Kluftverteilung innerhalb einzelner Bänke, unterschiedliche diagenetische Einfluss und verschiedenartiger Spannungsbarrieren schwierig. Das ist insbesondere für die Charakterisierung der Kluftnetzwerke und ihre Nutzung in Aufschluss-Analogstudien problematisch, welche für die Einschätzung des Fluidtransports in solchen Systemen 
verwendet wird. Die Ergebnisse dieser Studie sind zur Optimierung der Quantifizierung von Kluftverteilung und -ausbreitung in heterogenen Gesteinsabfolgen entscheidend und präzisieren die Definition mechanischer Einheiten. Diese Definition ist eine wichtige Voraussetzung für die Vorhersage von Kluftpermeabilitäten und folglich entscheidend für Fluidtransportmodelle. 


\section{-Preface-}

This doctoral thesis was part of the project 'Fracture propagation and reservoir permeability in limestone-marl alternations' that was financially supported by the Deutsche Forschungsgemeinschaft (DFG) (applied by Sonja L. Philipp; grant PH 189/2-1). The following publications and manuscripts are part of this doctoral thesis (corresponding author underlined):

Afșar F., Westphal H., Philipp S.L. (2014) How facies and diagenesis affect fracturing of limestone beds and reservoir permeability in limestone-marl alternations. Marine and Petroleum Geology, 57, 418-432 (Chapter 6 of this thesis).

Afșar F., Westphal H., Philipp S.L. (in review since 13.08.2014) Effects of stress barriers on reservoir permeability in layered rocks: A case study of Blue Lias rhythms (Bristol Channel Basin, UK). American Association of Petroleum Geologists Bulletin (Chapter 7 of this thesis).

Afșar F., Philipp S.L., Westphal H., (in preparation) Assessing the influence of diagenesis in limestone-marl alternations on metre to micrometre scale and the effects of diagenetic features on fracture propagation (Chapter 8 of this thesis).

Philipp S.L., Afşar F., Gudmundsson A. (2013) Effects of mechanical layering on hydrofracture emplacement and fluid transport in reservoirs. Frontiers in Earth Science, 1, 1-19 (Chapter 9 of this thesis).

Afşar F. (in preparation) Fracture arrest at limestone-marl contacts depending on marl thickness, stiffness and contact properties-Insights from BEM modelling (Chapter 10 of this thesis).

Contributions of the doctoral candidate:

In case of all first-author publications and manuscripts, the doctoral candidate was responsible for data collection, -analysis and -interpretation, as well as for writing of the manuscript. In case of the co-authored manuscript (Philipp et al., 2013) the doctoral candidate provided field data, prepared figures and revised the text. In addition to the project-related work, the doctoral candidate successfully applied for funding for additional analyses (International Association of Sedimentologists (IAS) postgraduate grant scheme, $2^{\text {nd }}$ session) and for attending the $30^{\text {th }}$ IAS Meeting of Sedimentology in Manchester (travel grants by Göttingen International and the International Association of Sedimentologists (IAS)). 


\section{-Acknowledgments-}

First of all I would like to sincerely thank Sonja Leonie Philipp and Hildegard Westphal for the realisation of the research project and for giving me the opportunity to work freely and independently. Furthermore, I would like to thank Jonas Kley, Frank Wiese, David Hindle and Elco Luijendijk for being on my thesis committee. I am indebted to Jan-Peter Duda, Elco Luijendijk, Sebastián Oriolo, Frank Wiese, Silke Meier and Annika Steichert for critical and inspiring discussions, constructive criticism and proofreading of parts of the thesis. Silke Meier and Johanna F. Bauer are thanked for a pleasant working atmosphere within the working group.

Joachim Reitner and Axel Munnecke are acknowledged for analytical and scientific support. Marie-France Hesse is thanked for helping with administrative issues. Jan-Peter Duda and Jonathan Lavi are acknowledged for assistance in the field. Andreas Reimer, Birgit Röring Sebastian Flotow and Dorothea Hause-Reitner are thanked for technical and analytical support. My reliable student assistants Tim-Lorenz Schäfer, Oliver Seidel and Hannes Räuschel are thanked for their constant support within the last three years.

I sincerely thank Jan-Peter Duda, my parents Aslan and Martina Afşar, my brother Adnan Afşar and his lovely family for their unwavering faith in me and their constant emotional support. Jan-Peter Duda, Sebastián Oriolo, Elco Luijendijk, Franziska Wilsky, Silke Meier, Cui Luo and Victoria Shushakova are thanked for their companionship and all the great times together, always full of laughter and fun. Axel Hackmann and Tim Brüggemann are thanked for fatherly advices and coaching during hard times.

This project was financially and logistically supported by the Deutsche Forschungsgemeinschaft (DFG, grant PH 189/2-1). The International Association of Sedimentologists (IAS, postgraduate grant scheme, $2^{\text {nd }}$ session) is thanked for providing financial support in the final phase of the project. Göttingen International and the International Association of Sedimentologists (IAS) are acknowledged for providing financial travel support. 


\section{-Table of contents-}

1. General introduction

1.1 Research motivation

1.2 Aims of the study

1.3 Thesis outline

2. Fractures in layered sedimentary rocks-Background knowledge

2.1 Types of fractures

2.2 Fracture networks in layered sedimentary rocks

2.3 Vertical fracture extension in layered sedimentary rocks

3. Limestone-marl alternation-Background knowledge

12-16

3.1 Cycles in general and limestone-marl rhythms in particular

3.2 Generation of limestone-marl rhythms

3.2.1 Sedimentary cycles

3.2.2 Differential diagenesis

4. Geological setting of the study areas

4.1 Tectonic development and structural geological features

of the Bristol Channel Basin

4.2 Sedimentology of the Bristol Channel Basin and the Blue Lias Formation

4.2.1 Mesozoic palaeogeography

4.2.2 Facies architecture and regional stratigraphy

4.2.3 Sedimentology and origin of the Blue Lias alternations

5. Methods overview

5.1 Structural geological approach

5.2 Sedimentological field techniques and measurements

5.3 Petrophysical measurements

6. How facies and diagenesis affect fracturing of limestone beds and reservoir permeability in limestone-marl alternations

6.1 Introduction

6.2 Fracture distribution-state of the art

6.3 Geological setting and study areas

6.4 Field and laboratory methods

6.5 Results

6.5.1 Sedimentology and diagenesis 36

6.5.2 Fracture distribution $\quad 41$

Fracture orientation and adjacent faults $\quad 41$

Fracture density and spacing 43 
Fracture height 46

6.6 Discussion $\quad 47$

$\begin{array}{ll}\text { 6.6.1 Fracture distribution in layered rocks } & 47\end{array}$

$\begin{array}{ll}\text { Fracture relation to faults } & 47\end{array}$

Fracture density and spacing associated with variation in bed

thicknesses and irregularities of bedding planes 48

Vertical fracture propagation in stiff beds $\quad 50$

6.6.2 Effects of bedding plane irregularities on fracture propagation 52

6.7 Implications for reservoir permeability and exploration 53

Acknowledgments $\quad 55$

References $\quad 56$

7. Effects of stress barriers on reservoir permeability in layered rocks: A case study of Blue Lias rhythms (Bristol Channel Basin, UK)

Abstract

7.1 Introduction

7.2 Geological setting $\quad 62$

7.3 Field and laboratory methods $\quad 65$

$\begin{array}{ll}7.4 \text { Results } & 66\end{array}$

7.4.1 Lithology and sedimentology of investigated sections 66

$\begin{array}{ll}\text { 7.4.2 Fracture data } & 70\end{array}$

7.5 Discussion-Effects of different stress barriers on vertical fracture $\begin{array}{ll}\text { propagation } & 72\end{array}$

$\begin{array}{ll}\text { 7.5.1 Mechanical interfaces } & 72\end{array}$

$\begin{array}{ll}\text { 7.5.2 Interbed thicknesses } & 78\end{array}$

$\begin{array}{ll}\text { 7.5.3 Interbed heterogeneities } & 78\end{array}$

$\begin{array}{ll}\text { 7.5.4 Definition of mechanical units } & 79\end{array}$

7.6 Conclusions and implications for reservoir permeability and exploration $\quad 80$

$\begin{array}{ll}\text { Acknowledgments } & 81\end{array}$

$\begin{array}{ll}\text { References } & 81\end{array}$

$\begin{array}{ll}\text { Appendix } & 85\end{array}$

8. Assessing the influence of diagenesis in limestone-marl alternations on metre to micrometre scale and the effects of diagenetic features on fracture propagation

$\begin{array}{lr}\text { Abstract } & 87\end{array}$

8.1 Introduction $\quad 88$

8.2 Methods $\quad 89$

$\begin{array}{ll}8.3 \text { Results and discussion } & 90\end{array}$

8.3.1 The influence of diagenesis on the limestone-marl alternations 90

8.3.2 Impact of diagenesis on fracture-associated permeability in limestone$\begin{array}{ll}\text { marl alternation } & 95\end{array}$

$\begin{array}{ll}\text { 8.4 Conclusions } & 99\end{array}$

Acknowledgments $\quad 99$ 
9. Effects of mechanical layering on hydrofracture emplacement and fluid transport in reservoirs

$\begin{array}{lr}\text { Abstract } & 101\end{array}$

9.1 Introduction 102

9.2 Reservoir fractures and fluid transport 103

9.2.1 Models of reservoir fractures 103

9.2.2 Fluid flow in fractured rocks 106

$\begin{array}{lr}\text { 9.2.3 Fluid transport in faults } & 110\end{array}$

9.3 Hydrofracture emplacement 112

$\begin{array}{ll}\text { 9.3.1 Hydrofracture initiation } & 112\end{array}$

$\begin{array}{ll}\text { 9.3.2 Hydrofracture propagation } & 113\end{array}$

$\begin{array}{ll}\text { 9.3.3 Fluid overpressure of hydrofractures } & 114\end{array}$

$\begin{array}{ll}\text { 9.3.4 Hydrofracture tip stresses } & 117\end{array}$

9.4 Hydrofracture emplacement in mechanically layered rocks 122

$\begin{array}{lr}\text { 9.4.1 Mechanical layering of reservoir rocks } & 122\end{array}$

9.4.2 Field observations and numerical model on hydrofracture emplacement $\quad 124$

$\begin{array}{ll}9.5 \text { Discussion } & 130\end{array}$

Acknowledgments 134

References $\quad 134$

10. Fracture arrest at limestone-marl contacts depending on marl thickness, stiffness and contact properties-Insights from BEM modelling

Abstract

10.1 Introduction

$\begin{array}{ll}10.2 \text { Numerical model geometries } & 143\end{array}$
10.3 Results and interpretation

10.3.1 Maximum principle tensile stress at boundaries (lithological contact and model surfaces)

$\begin{array}{ll}\text { 10.3.2 Distribution of tensile stress in layer A and B } & 148\end{array}$

$\begin{array}{ll}10.4 \text { Conclusions } & 150\end{array}$

10.5 Appendix $\quad 152$

References $\quad 156$ 


\section{-Chapter 1-}

\section{Introduction}

\subsection{Research motivation}

Fractures control the permeability of many reservoirs and the relation between fracturing and fluid flow is currently a topic of extensive research (e.g. Vigneresse, 2001; Berkowitz, 2002; Labaume et al., 2002; Neuzil, 2003; Dietrich et al., 2005; Dresen et al., 2006; Sahimi, 2011; Adler et al., 2012). Fractures generated by internal fluid pressure, for example, dykes, mineral veins, many joints and man-made hydraulic fractures, are referred to as hydrofractures (Philipp et al., 2013; see chapter 9 for details). Together with shear fractures, they contribute significantly to the permeability of fluid reservoirs such as those of petroleum, geothermal water, and groundwater (Philipp et al., 2013; see chapter 9 for details). If additionally the fracture network is well interconnected and reaches the percolation threshold (cf. Stauffer and Aharônî, 1994), fractures are very efficient paths for the migration of fluids in reservoirs (Mandl and Harkness, 1987; Aydin, 2000; Nunn and Meulbroek, 2002). Such reservoirs in which fractures have a significant effect on the fluid transport are generally referred to as 'fractured reservoirs' (Nelson, 1985; Aguilera, 1995). However, reservoirs in many cases are also characterised by mechanical layering, i.e. mechanical properties change between layers and hence fractures tend to be more confined to individual layers ('stratabound fractures'; Odling et al., 1999). Mechanically layered rocks, however, can also comprise non-stratabound fractures (i.e. vertically persistent over several layers; Odling et al., 1999) which strongly influence the fracture distribution and fracture-associated permeability in layered rocks (Gudmundsson and Brenner, 2001; Brenner, 2003). The dominant fracture system type (stratabound or non-stratabound fractures) in layered rocks may change depending on scale (cf. Odling et al., 1999). For instance, several layers (i.e. metre scale) can comprise mainly non-stratabound fractures and thus act mechanically as one single unit (Gudmundsson, 2011). Therefore, the characterisation and quantification of fracture networks in layered rocks is a crucial prerequisite for the prediction of fracture-associated permeability and the successful application of fluid flow models for such heterogeneous reservoirs. 
Many reservoirs for petroleum, natural gas, ground or geothermal water are such layered naturally fractured reservoirs. Unconventional hydrocarbon or geothermal reservoirs, for instance, are basically explored with comparable production techniques. In both cases specific layers and/or confined rock packages are first drilled vertically and then widespread laterally exploited by using horizontal drilling techniques. In order to raise the production rates, local permeability of the reservoir rocks is initially too low and so has to be artificially increased. By injecting fluids under high-pressure, the connectivity of pre-existing fractures is increased (i.e. 'hydraulic stimulation') or new fractures are generated (i.e. 'hydraulic fracturing') (Economides and Nolte, 2000). The artificial fractures should be ideally confined within reservoir rocks and the pathways of the created fracture network should be restricted to the target. However, fractures formed by hydraulic fracturing as well as stimulation may also propagate vertically trough adjacent layers. Unpredictable pathways of these generated fractures can reopen existing mineral veins or reactivate existing faults in the immediate vicinity of the stimulation source (cf. Moeck et al., 2009). The formation of such unexpected pathways potentially decreases the production of the target fluid, but could also result in an uncontrolled migration of the injected fluids into overlying groundwater aquifers (Gassiat et al., 2013). For assessing the risks of contamination it is inevitable to understand the mechanisms that control the propagation of fractures in layered rocks in greater detail.

\subsection{Aims of the study}

The main aim of this thesis is to improve the understanding of fracture distribution in layered rocks and to assess the effects of sedimentary and diagenetic features on fracture propagation in limestone-marl alternations of the Jurassic Blue Lias Formation (Bristol Channel Basin, United Kingdom). For this purpose methods of sedimentology (e.g. field observations, thin section petrography, scanning electron microscopy and carbon-nitrogen-sulfur analyses) and structural geology (e.g. modified scan-line method) were combined with petrophysical measurements (e.g. tensile and compressive strength-, hardness- and porosity-measurements). The presence of oil in shale beds (in Kilve, Somerset, Harvey and Gray, 2011) and the strong morphological variations of the limestone-marl alternations (ranging from limestonedominated to marl-dominated) make the Blue Lias Formation an interesting outcrop analogue for studying fracture networks. Since the characterisation and quantification of fracture networks in such heterogeneous rocks is still a critical and not completely solved problem for outcrop analogue studies, following research questions were placed as particular emphasis: 
1. How does the fracture distribution vary depending on the planarity of bedding planes and lateral variations in bed thicknesses of limestone beds?

Fracture studies investigating layered or bedded rock successions, as well as the resulting models of fracturing and fluid flow in reservoirs, typically use the simplification of laterally continuous beds (e.g. Schöpfer et al., 2011; Gudmundsson et al., 2012; Philipp et al., 2013; see chapter 9 for details). However, rocks of the Blue Lias Formation show a wide range of different bedding types and this simplification may lead to erroneous conclusions regarding the prediction of fracture propagation and reservoir permeability. In order to overcome this deficiency, the aim of this study is to improve the understanding of the fracture distribution in such variable layered rocks of the Blue Lias Formation, considering also planarity of bedding planes and lateral variations in thicknesses of limestone beds.

2. How do different stress barriers affect vertical fracture propagation and reservoir permeability in limestone-marl alternations?

The connectivity of fracture networks and thus the fracture-associated permeability in layered sedimentary rocks varies considerably between distinct layers (Philipp et al., 2013; see chapter 9 for details). In addition to the change of mechanical properties between layers (Warpinski et al., 1982; Hudson and Harrison, 2000), stress barriers such as lithological contacts, layer thicknesses and heterogeneities within layers apparently influence fracture propagation in layered rocks. Therefore the aim of this study is to evaluate the impact of these different stress barriers based on vertical fracture terminations.

3. Do diagenetic features from metre to micrometre scale affect the vertical fracture propagation in limestone-marl alternations?

Complementary to the first research question it is analysed to which extent features observable on micrometre scale confirm or challenge the previous conclusions from the studies before. The aim of this study is to improve the understanding of the effects of diagenetic features by conducting additional petrographic analyses on micrometre scale using scanning electron microscopy. Furthermore, the effects of these diagenetic features on the vertical fracture propagation in metre scale are discussed. 
4. How does mechanical layering affect hydrofracture emplacement and fluid transport in layered reservoirs?

A hydrofracture is a fracture partly or wholly generated by internal fluid pressure. The term 'hydrofracture' is well established for fluid-driven rock fractures, including mineral veins as well as many joints (e.g. Davis, 1983; Rummel, 1987; Bons, 2001; Gundersen et al., 2011; Bons et al., 2012). Aim of this part of the study is to review and to discuss the current knowledge about the effects of mechanical layering on the emplacement of hydrofractures in layered reservoirs under consideration of additional field and modelling data. This part of the study introduces the following research question.

\section{How do lithological contacts and layer thicknesses prevent fracture propagation?}

It has been commonly hypothesised that the contrast between materials with different properties, such as stiffnesses of different layers, is one crucial reason why lithological contacts act as stress barriers and limit fracture connectivity (e.g. Erdogan, 1972; Biot et al., 1983; Helgeson and Aydin, 1991). Aim of this study is to evaluate the impact of different lithological contacts and bed thicknesses on the fracture propagation by simulating the termination of hydro- and tensile fractures at different lithological contacts.

\subsection{Thesis outline}

The thesis consists of three main parts; the first part (chapters 1-5) comprises introductory chapters; the second part (chapters 6-8) integrates quantitative field data with laboratory data and interpretation of the study areas; in the third part (chapters 9 and 10), numerical models were made based on field data and laboratory analyses from the second part. In this part hydrofractures are the main focus.

This interdisciplinary $\mathrm{PhD}$ project covers aspects ranging from sedimentology over structural geology to petrophysics, making a broad introduction necessary. For this reason, background knowledge about fractures in layered rocks (chapter 2), the sedimentology and diagenesis of limestone-marl alternations (hapter 3), and the geology of the study area (chapter 4) are briefly reviewed. Following an overview about used methods and approaches (chapter 5), the results of this study are presented (chapters 6-10).

In chapter 6 the impacts of sedimentological and diagenetic features of limestone beds on the fracture distribution are predominantly investigated, while the influence of marl beds on 
vertical fracture propagation is addressed in chapter 7. In addition, in both chapters the gained results were expanded to vertical fracture propagation over several layers. $\underline{\text { Chapter } 8}$ is basically based on chapter 6 and includes additional petrographic analyses on the micrometre scale using scanning electron microscopy, in order to understand the influence of diagenetic features from metre to micrometre scale and to understand the effects of diagenetic features on vertical fracture propagation in such layered rocks.

The chapter 9 includes a detailed review about the meaning of mechanical layering for fluid flow in layered reservoirs with particular emphasis on the usability of fluid flow models. This provides important background information for chapter 10, in which numerical models based on the boundary-element method (BEM) simulate the termination of hydro- and tensile fractures at different lithological contacts.

In chapter 11 the main conclusions of the study are summarised and perspectives for following future studies are discussed. 


\section{-Chapter 2-}

\section{Fractures in layered sedimentary rocks-Background knowledge}

\subsection{Types of fractures}

Fractures are weakness planes that may result from the interplay between extrinsic forces and intrinsic mechanical properties of the rock itself. Depending on the relative displacement across the weakness plane, all fractures can be characterised as shear fractures or extension fractures (e.g. Fossen, 2010; Gudmundsson, 2011). The relative displacement of the latter is perpendicular to the fracture plane, while that of the former is parallel to the fracture plane (e.g. Narr and Suppe, 1991), but also mixtures of both fracture types are possible (hybrid fractures). Extension fractures in layered rocks generally form at initial flaws in stiff beds (i.e. beds with relatively high Young's moduli, such as limestone; cf. Bell, 2000) when the effective tensile stress reaches the tensile strength of the rock (cf. Mandl, 2005). Young's modulus is a measure of the stiffness of the rock and will here be referred to as stiffness. Following the tradition in engineering rock mechanics, layers with high Young's moduli are referred to as stiff and those with low Young's moduli as soft (cf. Gudmundsson, 2011). Extension fractures include tension fractures (formed in absolute tension) and hydrofractures. Tension fractures, which are formed due to high absolute tensile stress, are generally oriented perpendicular to bedding planes and their spacing tends to be more regular (e.g. Gudmundsson, 2011). In contrast, hydrofractures are generated by internal fluid overpressure and their spacing may be more irregular (Brenner and Gudmundsson, 2004). As it is difficult to distinguish tension fractures and hydrofractures in the field because the fluid may have disappeared after hydrofracture formation the general term extension fracture is used in this study. The term is equivalent to the field term 'joint' for a fracture with only slight fracturenormal displacement and without visible shear displacement. Some joints, however, may exhibit a small displacement parallel to the fracture plane so that in the strict sense they are no extension fractures (Narr and Suppe, 1991; Gudmundsson, 2011). 


\subsection{Fracture networks in layered sedimentary rocks}

Fracture networks in layered sedimentary rocks mostly consist of more than one fracture set. For example, alternations of stiff beds (e.g. limestones) and soft beds (e.g. marls; in the following referred to as 'interbeds') often contain systematic and non-systematic fracture sets in between (Gross, 1993; Fig. 2.1). Non-systematic fractures exhibit, in contrast to systematic fractures, non-planar surfaces and irregular, curved traces on bedding plane surfaces (Gross, 1993). Describing fracture networks in such alternations the distribution of different fracture sets have to be documented.

The fracture distribution can be mainly described by four related parameters: (1) fracture orientation (strike and dip); (2) fracture spacing in individual layers, commonly defined as the horizontal distance between two adjacent fractures (e.g. Narr and Suppe, 1991); (3) fracture density (number of fractures per metre) and (4) fracture connectivity. The distribution of fractures, however, is different in stiff beds and soft interbeds. For

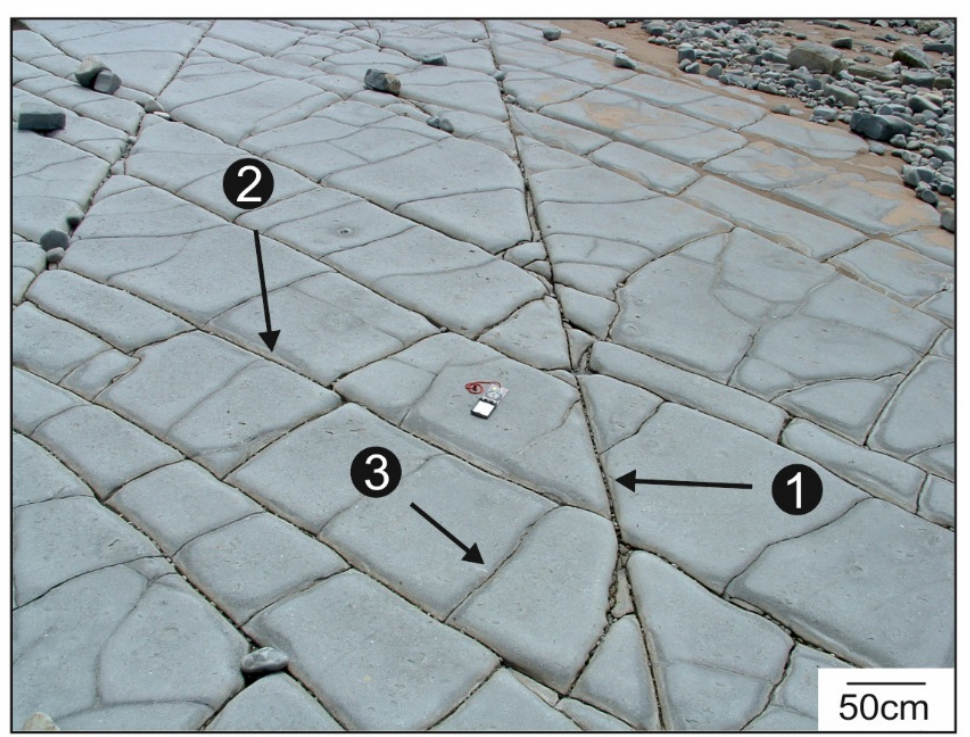

Figure 2.1: Fracture network of three fracture sets with two systematic fracture sets ( 1 and 2; 1 being the older set) and one non-systematic fracture set (3) in a limestone bed (seen from above) of the Blue Lias Formation in Nash Point (Wales , UK). instance, field observations show that in soft interbeds many inclined apparent extension fractures are actually shear fractures, subject to a higher normal stress $\sigma_{n}$ (Philipp et al., 2013; see chapter 9 for details). In contrast, in the stiffer beds mostly tension fractures and also hydrofractures occur with dips of almost $90^{\circ}$ (Philipp et al., 2013; see chapter 9 for details). The following discussion on fracture density and spacing therefore focuses on tension fractures in stiff beds.

The density or spacing of fractures commonly varies with structural position or lithology, in particular with rock mechanical properties (Aguilera, 1995). Several studies document increasing fracture spacing and decreasing fracture density with increasing bed thicknesses (e.g. Bogdanov, 1947; Ladeira and Price, 1981; Narr and Suppe, 1991; Wu and Pollard, 1995; 
Bai et al., 2000). However, it has been controversially discussed whether the relationship between fracture spacing and bed thicknesses is linear (e.g. Price, 1966; Hobbs, 1967; Sowers, 1972) or non-linear (e.g. Norris, 1966; Mastella, 1972; Mandal et al., 1994). The relationship between fracture spacing and bed thicknesses depends, among others, on the properties of the boundaries between stiff beds and soft interbeds confining these fractures. For example, pre-existing systematic fracture sets are commonly confined to stiff beds between mechanical layer boundaries (Gross, 1993; Fig. 2.2). These boundaries are defined by lithological contacts and thus are lithology-controlled (Gross, 1993; Fig. 2.2). For the nonsystematic fracture sets, in turn, the pre-existing systematic fracture sets act as mechanical layer boundaries; in this case mechanical layer boundaries are fracture-controlled (Gross, 1993; Fig. 2.2). For non-systematic fractures, a linear relationship should be observed of the spacing of non-systematic fractures with the spacing of the pre-existing systematic fractures (cf. Gross, 1993) rather than with the bed thickness discussed above. Other studies also found poor correlations between fracture spacing and bed thickness (e.g. Laubach et al., 2009; Boro et al., 2013), but stronger relationships between fracture spacing and the thicknesses of 'fracture units', the latter being defined as groups of sedimentary beds with homogeneous fracture patterns (e.g. Laubach et al., 2009; Boro et al., 2013).

One of the first theoretical explanations of a linear relation between tension fracture spacing and layer thickness in sedimentary rocks was made with the stress-shadow concept (cf. Lachenbruch, 1961; Fig. 2.3).

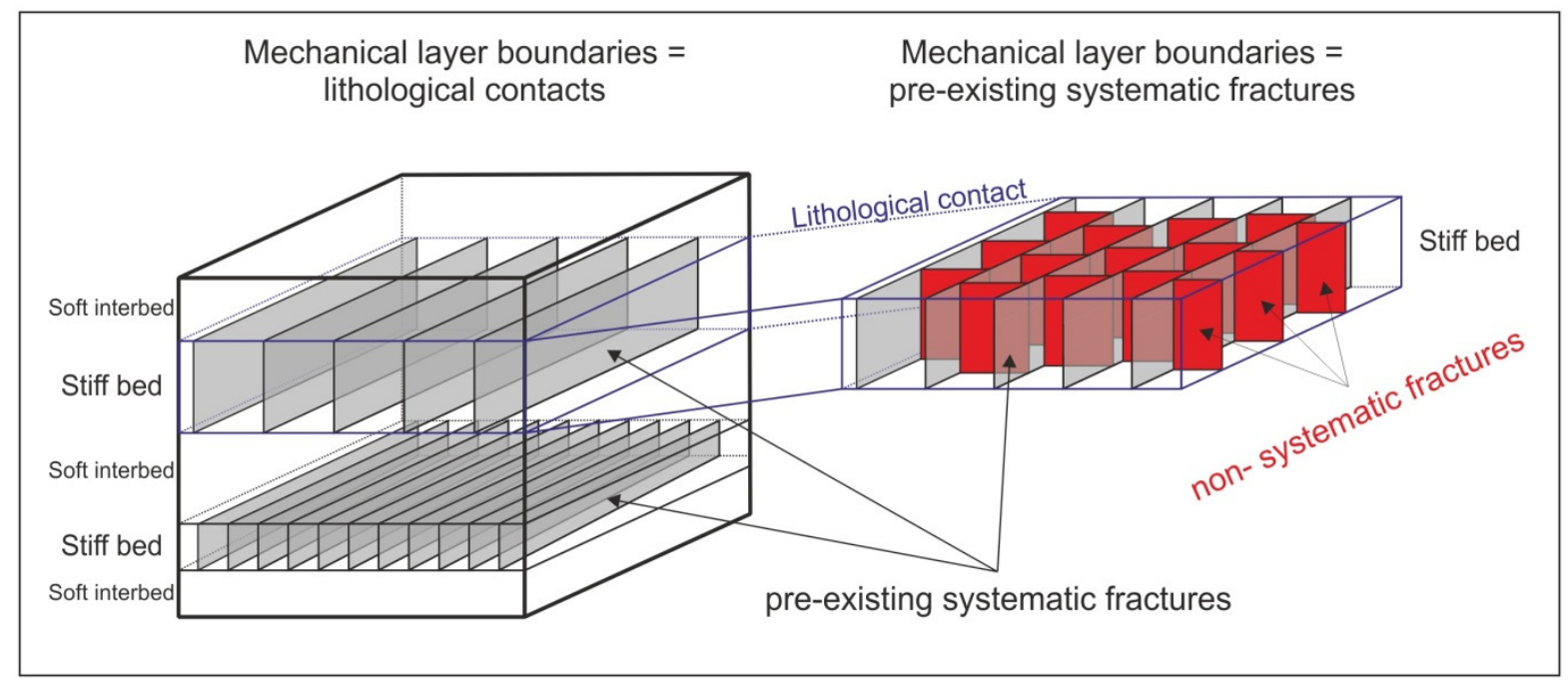

Figure 2.2: Fracture networks in layered sedimentary rocks often contain orthogonal fracture sets, consisting of systematic and non-systematic fracture set. Pre-existing systematic fractures are confined to mechanical layer boundaries defined by lithological contacts (lithology-controlled) and non-systematic fractures are confined to mechanical layer boundaries defined by pre-existing systematic fractures (fracture-controlled; modified after Gross, 1993). 


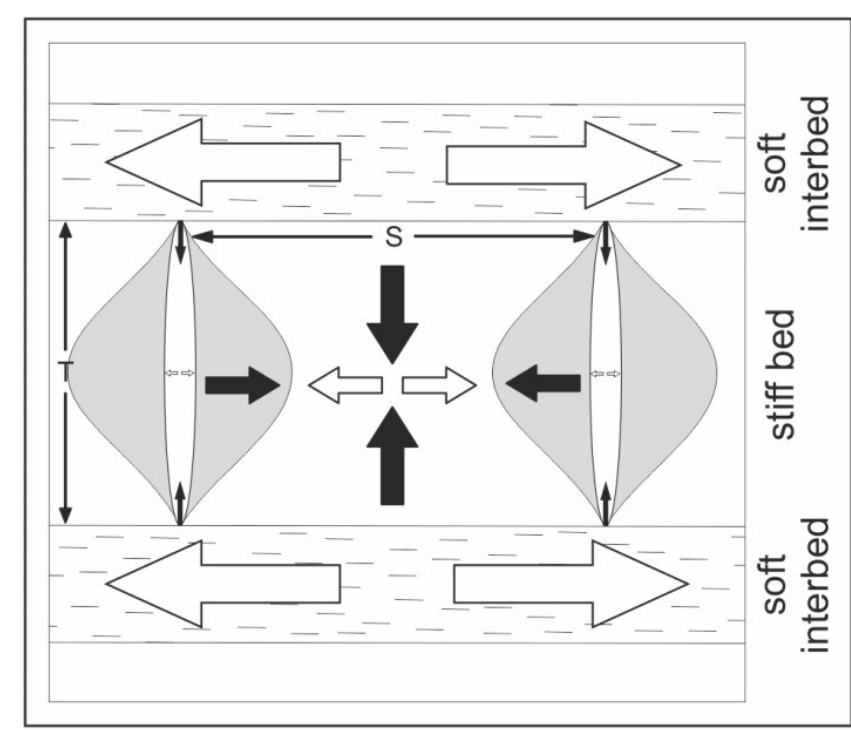

Figure 2.3: Conceptual model of stress shadow (grey area) between adjacent fractures ( $\mathrm{T}=$ thickness of the stiff bed, $\mathrm{S}=$ spacing between adjacent fractures, regarding the infilling area, white arrows $=$ tensile stress, solid arrows $=$ compressive stress; after Bai et al., 2000). Arrow sizes represent stress magnitudes.
The concept only applies to tension fractures oriented perpendicular to bedding planes which are not healed or sealed (i.e. still open fractures). Because of the traction-free condition at the fracture surfaces, the stress increases with increasing distance from the fracture surfaces (forming a 'stress shadow'; cf. Lachenbruch, 1961; Fig. 2.3).

New infilling fractures only form, if the tensile stress reaches the tensile strength. The minimum spacing thus depends on the width of the stress shadow, which is scaled with fracture height (e.g. Becker and Gross, 1996).

As the formation of infilling fractures is limited thereby, the fractured layer can reach a saturation of fractures ( $\mathrm{Wu}$ and Pollard, 1995; and references therein). When fracture saturation is reached, the spacing only depends on bed thickness and thus should be relatively regular. For hydrofractures, which are driven by fluid overpressure, in contrast, fracture spacing may be much lower or even infinitely low than in tensile fractures and depends not on bed thicknesses (e.g. Gudmundsson, 2011).

Fluid flow through a fracture network depends mainly on the connectivity of the fractures, that is, if the percolation threshold is reached (cf. Stauffer and Aharônî, 1994). A percolation network can be described in terms of three types of elements: (1) backbone elements provide a direct connection within a defined area, (2) dangling elements are dead-end elements but connected to the backbone elements and (3) isolated elements are disconnected from the network (Cox, 1999).

Relevant are the horizontal and the vertical connectivity of the fracture system because the fracture-associated permeability can vary considerably not only parallel but also perpendicular to the bedding. The connectivity of a fracture network is determined with measuring fracture traces at exposed rock surfaces. That means the fracture trace (length in horizontal, height in vertical dimension, respectively), strike and connectivity are documented on a defined bedding plane surface, or in a vertical outcrop wall, respectively. There are three 
main approaches for sampling; 1) fracture traces detected within a defined square (window sampling), 2) traces detected within a circle (circle sampling) and 3) traces intersecting a straight line (scan-line sampling). The latter approach is the most practical (Priest, 2004). For evaluating the vertical connectivity in layered rocks, a method of modified scan-line sampling (Afşar et al., 2014; see chapter 6 for details) was developed focussing on the fracture height, and thus the vertical fracture extension over more than one layer.

\subsection{Vertical fracture extension in layered sedimentary rocks}

The connectivity of fracture networks and thus the fracture-associated permeability in layered sedimentary rocks may vary considerably from layer to layer (Philipp et al., 2013; see chapter 9 for details). A reason for that is that fracture propagation is largely controlled by the change of mechanical properties and by the change of the state of stress in different layer (Warpinski et al., 1982; Hudson and Harrison, 2000). The local stress field together with pre-existing discontinuities (i.e. significant mechanical breaks; Priest, 1992) ahead of the fracture tip largely determines the fracture-propagation path. Favorably oriented discontinuities ahead of the tip open up when they are subject to tensile stresses that exceed their tensile strengths (cf. Philipp et al., 2013; see chapter 9 for details).

However, different kind of stress barriers that prevent the fracture propagation in layered rocks may exist, such as contrasts in rock properties ('mechanical layering') and/or contacts between different lithologies. Rock masses where the mechanical properties change between layers are commonly referred to as mechanically layered (Philipp et al., 2013; and references therein; see chapter 9 for details). Mechanical layering may coincide with changes in grain size, mineral content, or facies. For example, in layered sedimentary reservoirs, such are common in carbonates (limestone-marl alternations) or siliciclastics (sandstone-clay alternations), some rock types forming individual layers (such as limestone or sandstone) may be considerably stiffer than other layers (such as marl or clay) (Bell, 2000; Schön, 2004; Gudmundsson, 2011). Stiff beds can act as stress barriers to vertical hydrofracture propagation, when the rock mass is subject to horizontal compression and the beds are likely to take up most of the compressive stress (Gudmundsson and Brenner, 2001). In contrast, soft interbeds can act as stress barriers, when the rock mass is subject to horizontal tension (Gudmundsson and Brenner, 2001).

In many layered rocks, predominantly in sedimentary rocks at shallow depths, the contacts between different lithologies can act as stress barriers as well, illustrated in different variations of fracture pathways (Fig. 2.4). Not only are there fractures terminating at 
lithological contacts, also fractures cutting collinearly through (Fig. 2.4A) or side-stepping (also referred to as offset) along contacts (Fig. 2.4B) or propagating in an inclined path through soft interbeds (Fig. 2.4C) occur. Models of Price (1966) and Hobbs (1967) theoretically explain why fractures become arrested at some but not at all contacts. The 'slipmodel' developed by Price (1966) for instance assumes interfacial shear stress directly at the contact between stiff beds and soft interbeds and are thus non-welded lithological contacts. The term 'welded' is generally used for strong cohesive bonds on contacts (cf. Hobbs, 1967). Non-welded lithological contacts are weak or open and fractures become either arrested or offset and continue side-stepping upwards (cf. Gudmundsson et al., 2002; Gudmundsson, 2006). In contrast, when the contact is strongly cohesive, fractures tend to propagate collinearly through the contacts ('welded-layered model'; Hobbs, 1967). If a layered rock mass additionally has the same Young's modulus throughout, and if the layers are welded together so that there are no weak or open contacts, the layers may function mechanically as a single unit (Philipp et al., 2013; see chapter 9 for details).
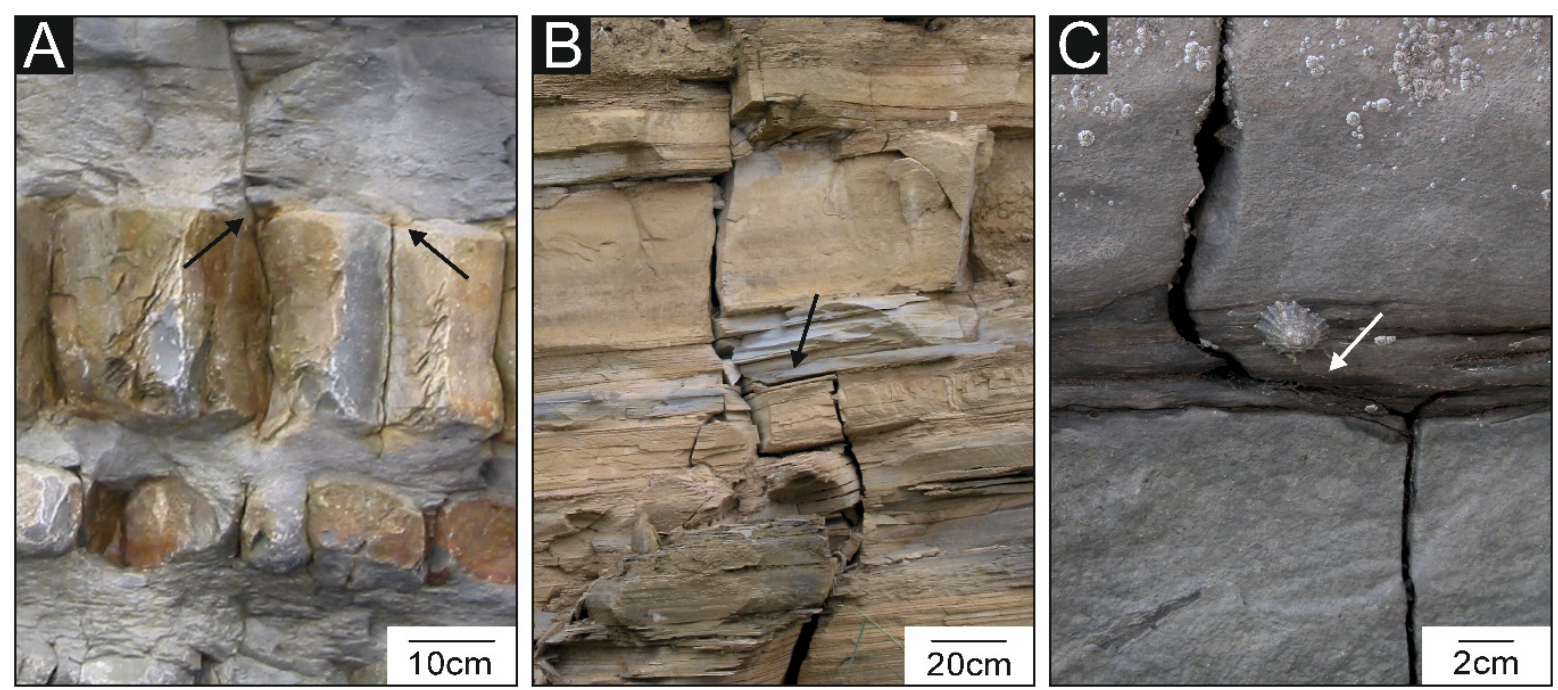

Figure 2.4: Fracture pathways through alternations of stiff beds and soft interbeds. A) Fractures terminate at (right arrow) or cut through (left arrow) lithological contacts; B) fracture side-step (also referred as offset) along a contact and propagates subsequently into adjacent beds and interbeds; C) fracture propagates inclined through a soft marl interbed. 


\section{-Chapter 3-}

\section{Limestone-marl alternations-Background knowledge}

\subsection{Cycles in general and limestone-marl rhythms in particular}

Two types of sedimentary sequences can be generally distinguished: rhythmic sequences (succession $\mathrm{AB}, \mathrm{AB}$, etc.) with two alternating bed types and cyclic sequences (succession ABC, ABC, etc.) with several different sediment types and at least three bed types (Fig. 3.1A) (Einsele et al., 1991). Both types of sequences are subdivided into four groups, with different scales and time periods: (1) varve-scale laminations, (2) bed-scale rhythms and cycles, (3) field-scale sedimentary cycles (including third- and forth order cycles) and (4) various orders of macro-scale cyclic sequences (i.e. supercycles and megacycles, according to the Vail-Haq nomenclature; Vail et al., 1977; Haq et al., 1987) (Einsele et al., 1991; Fig. 3.1B). Bed thicknesses within the bed-scale rhythms and cycles can vary from a few centimetres to several metres, representing various time spans ranging from seconds to several $100 \mathrm{ka}$. Bed thicknesses within field-scale sedimentary cycles, however, can vary from several metres to tens of metres and the marine ones represent global and relative sea-level changes on the order of $100 \mathrm{ka}$ to several Ma (Einsele et al., 1991).

The terms 'limestone' and 'marl' are generally used in a descriptive sense and are well distinguishable in the field because of the more resistant to weathering layers ('limestones') and intercalated less resistant layers ('marls') (Flügel, 2010). The term 'couplet' is generally used for a marl-limestone pair (cf. Einsele et al., 1991). The boundaries between couplets are usually sharp and the highest carbonate content occurs in the central part of limestone beds or nodules (Flügel, 2010). 'Bundles' represent several bedding couplets separated by thicker marls (Schwarzacher, 1975; cf. Einsele et al., 1991). 


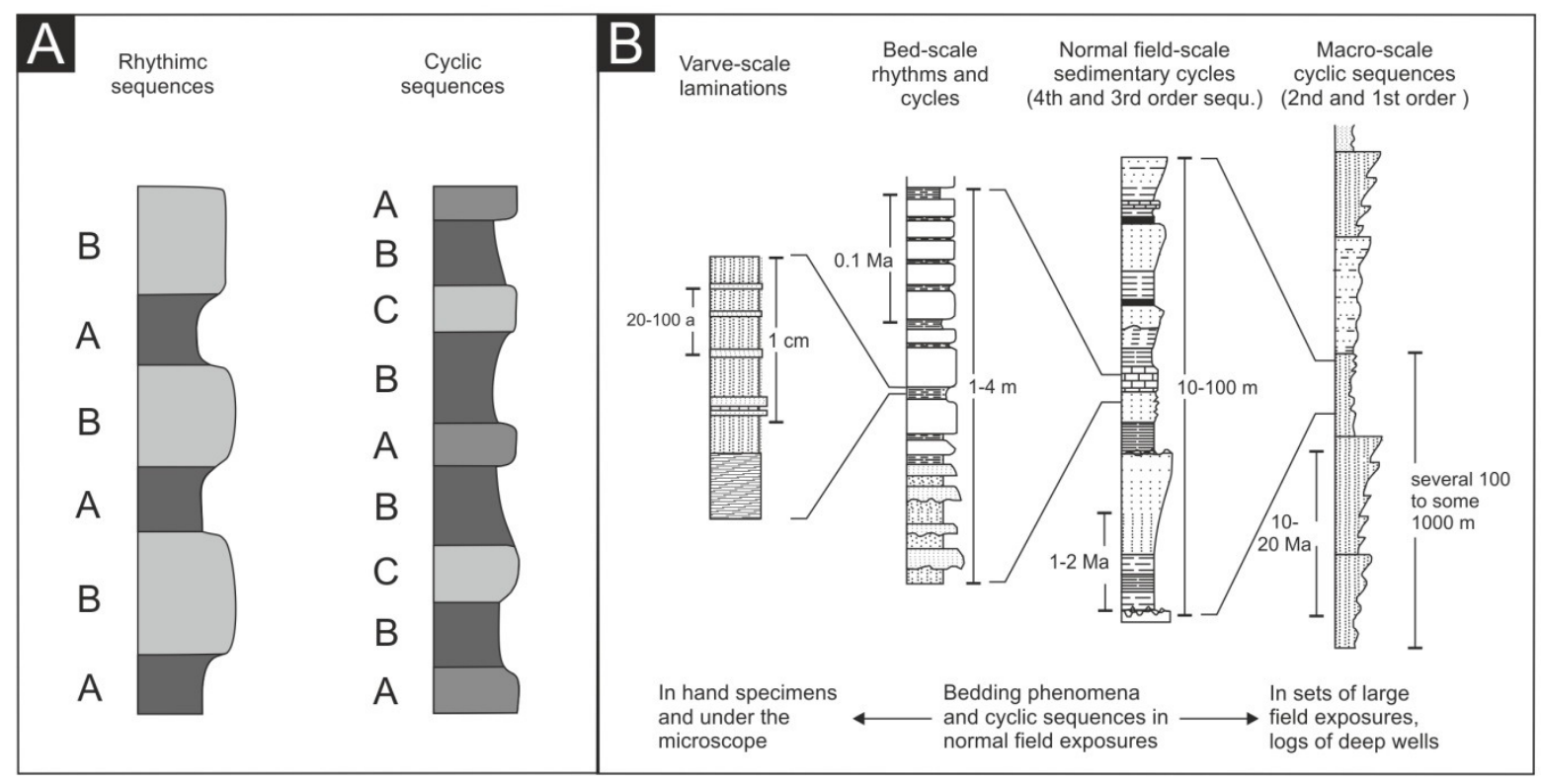

Figure 3.1: Classification of sequences. A) Two sequences can be distinguished (rhythmic and cyclic sequences; modified after Einsele et al., 1991); B) Both sequences can be subdivided into four groups, with different scales and time periods (modified after Einsele et al., 1991).

\subsection{Generation of limestone-marl rhythms}

Not only the morphological appearance of limestone-marl alternations shows wide variations (from nodular to well-bedded), but also the environmental setting (from shallow-water to deep-marine), in which limestone-marl alternations (LMA) have been deposited show wide variations (e.g. Westphal and Munnecke, 2003; Westphal et al., 2008). Evidencing unequivocally a solely sedimentary (i.e. lithological differences due to primary sediment change) or differential diagenetic (i.e. limestones and marls underwent different diagenetic pathways) origin for LMA, however, is a great challenge because in both cases strong lithological differences because of lithification, diagenesis and weathering processes after deposition can finally be observed in the field (Westphal et al., 2008). Not only the diagenesis but also different weathering effects make an unequivocal identification of primary signals difficult. This means primary sedimentary signals far below or above the range between 70 to $90 \% \mathrm{CaCO}_{3}$ of the sediment can be concealed ('weathering boundary'; Einsele, 1982). The appearance of soft back weathering marl layers and weathering resistant, exposed limestone beds can only be recognised in the field if the initial sediment had carbonate content fluctuation around this weathering boundary (range between 70-90 \% $\mathrm{CaCO}_{3}$ content; 
Einsele, 1982). This weathering effect depends on climate influence and several other variables, such for example length of exposure (Ricken, 1986).

In the following subchapters the scientific disciplines of the sedimentary origin and the diagenetic generation of LMA will be respectively presented and the problems to demonstrate both scientific disciplines will be discussed.

\subsubsection{Sedimentary cycles}

For the initial differences between limestones and marls, generally fluctuations in carbonate supply (productivity cycles; Seibold, 1952) or periodic increases and decreases in clay supply (dilution cycles; Einsele, 1982) driven by orbital forcing are assumed. It is not always clear; however, which supply influences the cyclicality. The question arising in many cases if the carbonate component remained constant and the clay influx fluctuated or vice versa (Seibold, 1952). Not only climatic fluctuations are important for the generation of LMA, but also sedimentary aspects such as accumulation rates, conditions of preservations and waterchemistry can be determinant for sedimentary sequences (Schwarzacher, 1993). Vertical sequences of distinct sedimentary structures can also initiated for instance by episodic turbidity currents, the resulting limestone turbidites ('calciturbidites') are interbedded with fine pelagic sediments representing the background sedimentation (Flügel, 2010).

It is well established that the seawater-chemistry changes between aragonite ('Aragonite Sea') and high-Mg calcite ('Calcite Sea') during geological time ('Sandberg model'; Sandberg, 1983, 1985 and 'Stanley-Hardie model'; Stanley and Hardie, 1999). The abundance of LMA is roughly coherent with the oscillations between calcite and aragonite seas, which mean high abundances during times of 'Calcite Sea' and lower abundances during times of 'Aragonite Sea' (Westphal et al., 2008). After the 'Sandberg model' based on non-skeletal carbonates, the Triassic-Jurassic boundary represents the transition from an 'Aragonite Sea' to a 'Calcite Sea', whereas for the same period the 'Stanley-Hardie model' postulates an 'Aragonite Sea' based on skeletal carbonates.

\subsubsection{Differential diagenesis}

The term 'differential diagenesis' means different diagenetic pathways between limestones and marls (Reinhardt et al., 2000; Westphal et al., 2000). Initial considerations were made considering the idea of donor-receptor diagenetic development with leaching from a 'donor' limestone and yielding to a 'receptor' limestone (Bathurst, 1971). This idea was later applied 
for LMA, where differentiation of mud sediments by dissolution of $\mathrm{CaCO}_{3}$ in carbonate-poor layers and cementation by migration of $\mathrm{CaCO}_{3}$ in carbonate-rich layers was accompanied (Ricken, 1986; Fig. 3.2). Through the dissolution of $\mathrm{CaCO}_{3}$ in later marls, marls tend to be more compacted. The carbonate compaction law was a first attempt that tried to calculate the degree of compaction (Ricken, 1987). In contrast to the model by Ricken (1986), that assumes pressure dissolution of calcium carbonate in the deep-burial environment due to chemical compaction as source for the cement in limestones, the model by Munnecke and Westphal (2005) is based on redistribution of calcium carbonate by aragonite dissolution and calcite reprecipitation at shallow marine burial depth.

A clear indication for aragonite dissolution during early diagenesis in the shallow marine environment, prior to mechanical compaction, is the 'differential compaction' caused by 'differential diagenesis' (Reinhardt et al., 2000; Westphal et al., 2000). Cementation in limestone beds occurs very early and prior to compaction as indicated by undeformed fossils, and at the same time, the marl interbeds are strongly compacted and show signs of dissolution in aragonite components as indicated by deformed fossils (Westphal et al., 2008). A further evidence for aragonite dissolution is the lack of aragonite fossils in marls and the neomorphized but not completely dissolved aragonite shells in limestones (Munnecke and Samtleben, 1996). In addition, mass-balance calculations indicate that only $10-20 \%$ of aragonite in the primary sediment is sufficient to 'fuel' diagenesis (Munnecke et al., 2001). The 'differential diagenesis' was initiated by modification of the pore-water chemistry by bacterial oxidation of organic matter using sulphate (Melim et al., 2002).

Evidencing of unequivocally pure

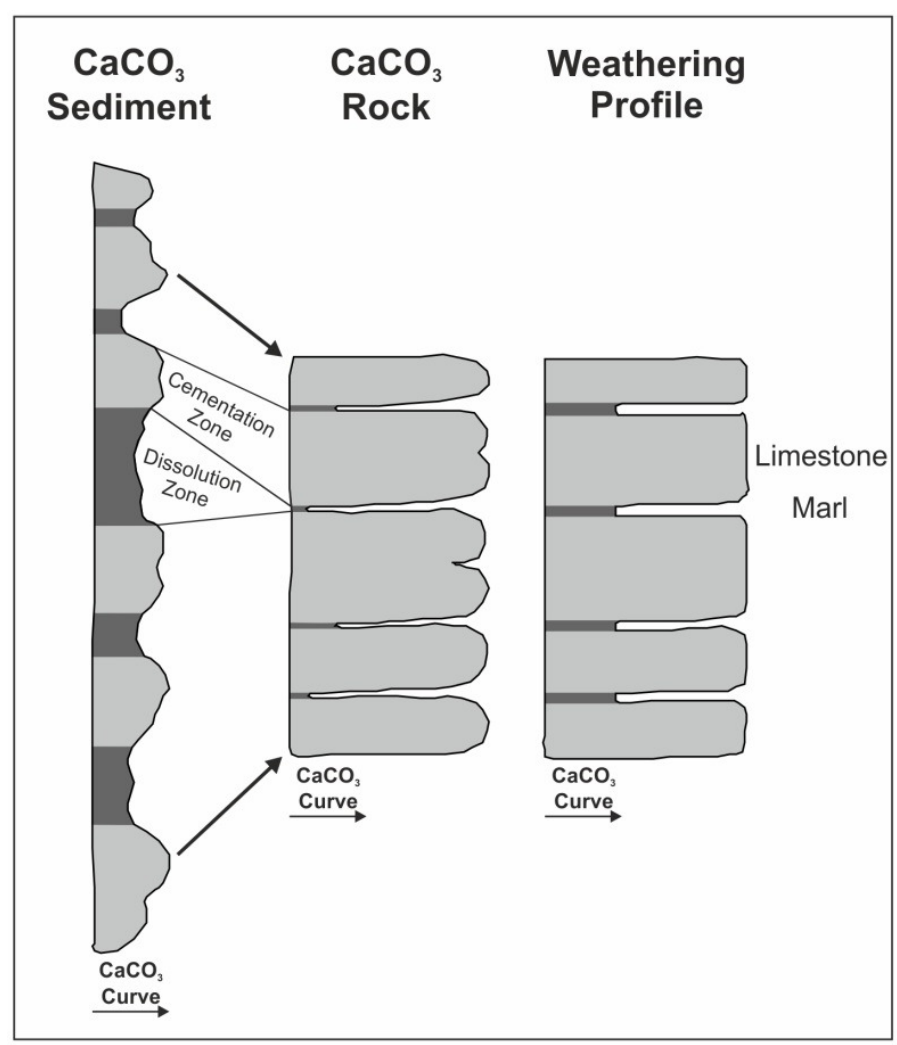

Figure 3.2: Concept of diagenetic bedding. Differentiation of primary mud sediments in dissolution and cementation zones (left) into a rhythmic LMA (right; modified after Ricken, 1985). primary or pure diagenetic alternations is challenging. However, for reliable interpretation it 
is crucial to identify primary signals and distinguish them from diagenetic features (cf. Hallam, 1986). Remobilisation of $\mathrm{CaCO}_{3}$ in certain layers causes a passive enrichment of inert non-carbonate fraction in these layers, whereas the reprecipitation of $\mathrm{CaCO}_{3}$ in other layers causes active dilution of inert non-carbonate fraction in the other layers (cf. Westphal et al., 2008). Therefore, information about systematic differences in the precursor sediments of limestones and interlayers is preserved only in parameters that are not modified during diagenesis (Westphal et al., 2008). 


\section{-Chapter 4-}

\section{Geological setting of the study areas}

\subsection{Tectonic development and structural geological features of the Bristol Channel Basin}

The study areas are located on the northern (i.e. Wales) and the southern margin (i.e. Somerset) of the Bristol Channel. The sections in Wales (NP1-NP3) are located at the north and the sections in Somerset (KI1, LIL2, KN3) are located at the south margin of the Bristol Channel Basin (Fig. 4.1).

The recent structure of the Bristol Channel Basin is the result of diverse tectonic history (Kamerling, 1979). However, the initial tectonics that controls the architecture of the basin most is related to the Variscan orogeny (cf. van Hoorn, 1987; Brooks et al., 1988). Development of the Bristol Channel Basin started during the Permo-Triassic Rifting with an N-S extension direction, which reactivated the Hercynian thrust zone (van Hoorn, 1987). As a consequence of NE-SW to NNE-SSW extension during Late Triassic and Jurassic, regional subsidence of the basin took place (Dart et al., 1995; Nemčok et al., 1995). Rifting continued until the Lower Cretaceous (Aptian), when the maximal burial depth was reached (Nemčok et al., 1995; and references therein). Vitrinite reflectance data indicate that the Liassic source rocks were buried to at least $2.25 \mathrm{~km}$, and possibly as much as $3.2 \mathrm{~km}$ (Nemčok et al., 1995; and references therein). The basin was inverted during the late Cretaceous and early Tertiary due to N-S compression associated with the Alpine orogeny (Dart et al., 1995; Nemčok et al., 1995).

The structure of the Bristol Channel Basin is commonly interpreted as a northerly deepening asymmetric graben that is bounded to the north by the east-west-trending south-dipping Central Bristol Channel Normal Fault (Tappin et al., 1994; Fig. 4.1). The present-day structure of the Bristol Channel Basin can be roughly subdivided into two basins: the ENEWSW trending Main Bristol Channel Basin (which is located more offshore) and the E-W trending East Bristol Channel Basin (Fig. 4.1; e.g. Kamerling, 1979).

In the East Bristol Channel Basin, $2.3 \mathrm{~km}$ of Triassic-Jurassic sediments were accommodated and the Middle and Upper Jurassic strata are completely preserved in the centre of this Basin (Kamerling, 1979). The major fault systems along the basin margins were active during the 
Mesozoic N-S extension (e.g. Kamerling, 1979; van Hoorn, 1987). Many normal faults were reverse-reactivated during the late Cretaceous and early Tertiary N-S compression (e.g. Dart et al., 1995; Nemčok et al., 1995).

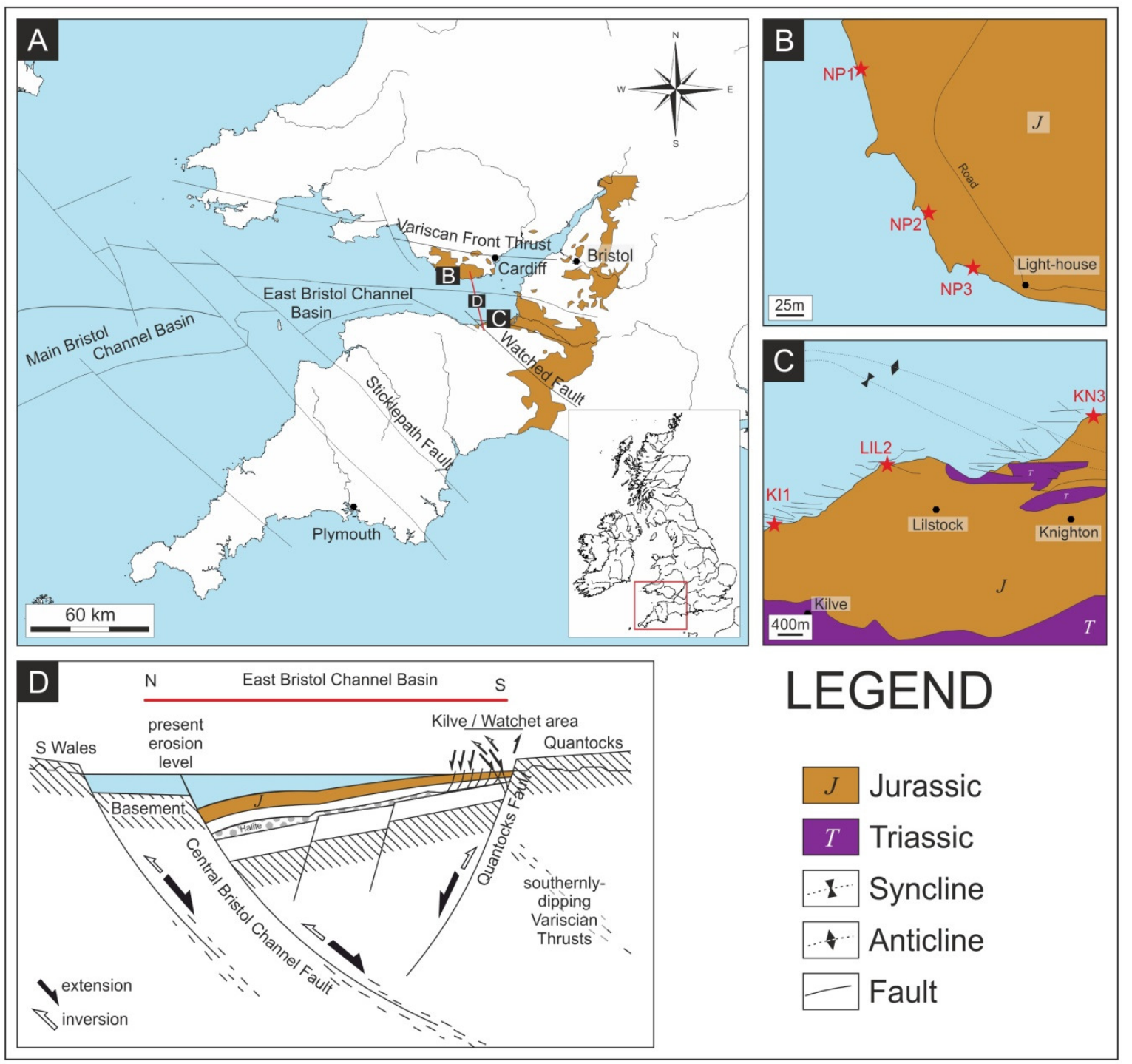

Figure 4.1: A) Map of the Bristol Channel area (map created with Generic Mapping Tools; GMT) with principal structural elements (map modified after Kamerling, 1979; Tappin et al., 1994). Location of the investigated sections (B and C; the cross section of the graben system is marked with a (D) along the Bristol with a generalised outcrop map of the Lias Group in orange (Blue Lias Formation is a part of the Lias Group; Cox et al., 1999); B) Location of sections NP1-3 in Wales; C) Location of sections KI1, LIL2 and KN3 in Somerset (map modified after Glen et al., 2005; Belayneh and Cosgrove, 2010); D) Cross-section of the eastern part of the Bristol Channel Basin (Stewart et al., 1997).

However, reverse faulting was more prevalent on the southern margin (Somerset) than on the northern margin (Wales) of the Bristol Channel Basin (Nemčok et al., 1995), along with faulting and fracturing revealing different evolution on both sites as well. The rocks in Wales 
are mainly affected by a series of thrusts and related strike-slip faults, the most of which were inherited Mesozoic normal faults. The major fracture set strikes NW parallel to these strikeslip faults (Petit et al., 1999). The fracture set oriented perpendicular to these strike-slip faults formed in response to the Cretaceous-early Miocene compression (Pascal et al., 1997). Most of the joint sets in Somerset were formed during the Alpine orogeny during three minor tectonic events (Engelder and Peacock, 2001). The first joint set formed during the late Oligocene to Miocene NW-SE compression (Engelder and Peacock, 2001). Due to a counterclockwise rotation of the regional maximum horizontal stress from NW-SE to NE-SW through an E-W orientation, the next joint sets developed (Engelder and Peacock, 2001; and references therein). The exhumation in a late-stage Alpine stress field was responsible for the youngest NW-striking joints (Hancock and Engelder, 1989) in the study area.

\subsection{Sedimentology of the Bristol Channel Basin and the Blue Lias Formation}

\subsubsection{Mesozoic palaeogeography}

The Triassic was dominated by strong monsoonal circulations (Parrish, 1993) and the Bristol Channel area drifted northwards from a palaeolatitude of about $16-34^{\circ} \mathrm{N}$ (Brenchley and Rawson, 2006). During the Jurassic period the area lay within a palaeolatitude around $35^{\circ} \mathrm{N}$, and was drifting steadily northwards (Smith et al., 1994). The palaeotemperature ranged from 12 to $29^{\circ} \mathrm{C}$ (estimated based on oxygen isotopes in marine invertebrates and vertebrates) at humid subtropical climate (Woodcock and Strachan, 2002). Sedimentation rates may have been drastically changing due to strong seasonal rainfall (Woodcock and Strachan, 2002). During the late Triassic and early Jurassic, landmasses were progressively inundated by the Tethyan transgression (Truemann, 1922; Wilson et al., 1990; and references therein) and the Palaeozoic basement became isolated islands within an epeiric ocean connected with the north-western Tethys (cf. Cope, 2006). The transgression continued throughout the Early Jurassic during the time of steady basin subsidence (Tappin et al., 1994; and references therein). A sedimentation rate of approximately $3.5 \mathrm{~cm} / \mathrm{ka}$ has been estimated in the depocentres (Tappin et al., 1994; and references therein). 


\subsubsection{Facies architecture and regional stratigraphy}

As a consequence of the Tethyan transgression, the palaeosurface was deeply eroded and a Liassic shallow marine facies was accommodated unconformable above a Carboniferous Limestone basement on the northern margins of the Bristol Channel Basin (Fletcher, 1988). Late Triassic to Early Jurassic successions could be accommodated in the Somerset area due to the south deepening paleo platform. The Hettangian-Sinemurian boundary is well exposed at the Somerset coast north of Kilve and was thus appropriated as a Global Stratotype Section and Point (GSSP; Bloos and Page, 2002).

The Island of the Landmass in Wales (also called St Davids's Archipelago) is onlapped by a basin-marginal littoral succession, which consist of the proximal (Sutton Stone) and the intermediate (Southerndown Beds) to the distal (Blue Lias Facies) due to lateral facies changes (Trueman, 1922; Ager, 1974; Wilson et al., 1990). The facies architectures are strongly influenced by the ancient shoreline of the Carboniferous basement, and a series of retrogradationally stacked parasequences of these three successions can be observed (Sheppard, 2006; Fig. 4.2A). The younger deposits above the Carboniferous basement platform strongly record the signature of a rapid marine transgression (Sheppard, 2006).

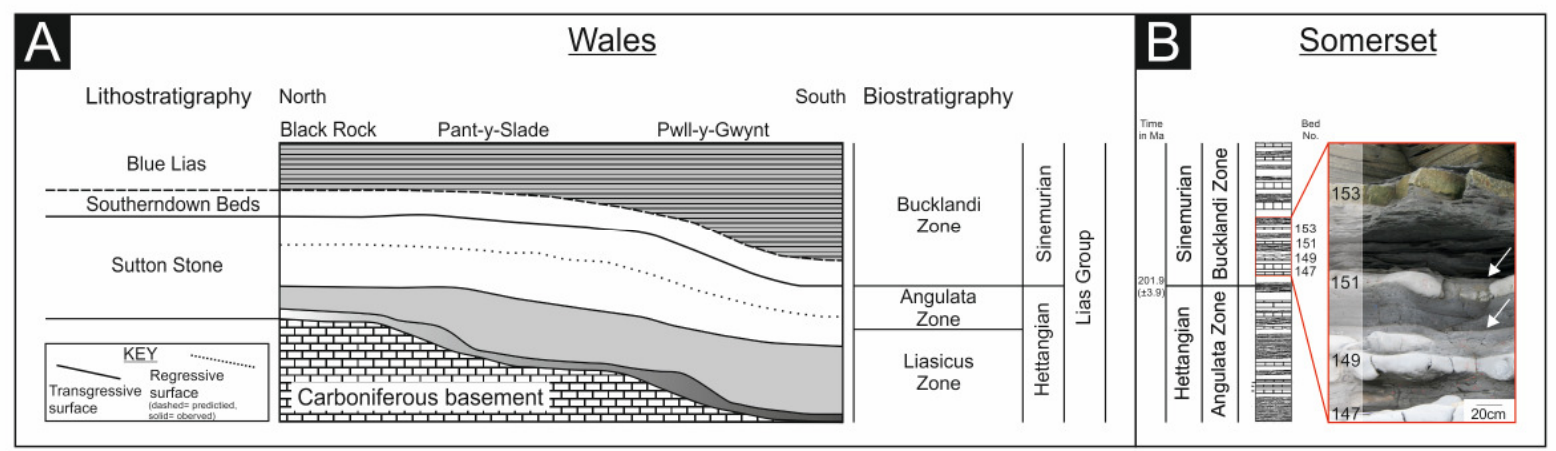

Figure 4.2: A) Lithostratigraphy, illustration of retrogradationally stacked parasequences and ammonite biostratigraphy of Lower Jurassic rocks in Wales (not scaled; modified after Sheppard, 2006); B) Blue Lias Formation in Kilve (Somerset) shows sedimentary cycles (cycle boundaries are indicated by white arrows; after Bloos and Page, 2002) and bed numbers (after Whittaker and Green, 1983).

The Sutton Stone is a massive light grey coarsely conglomeratic rock that contains clasts of Carboniferous basement and a wide variety of fossils (George, 1970; Brenchley and Rawson, 2006). The well-stratified Southerndown Beds are derived from the Carboniferous basement as well (George, 1970). 


\subsubsection{Sedimentology and origin of the Blue Lias alternations}

Rocks of the Blue Lias Formation (Hettangian-Sinemurian) are well exposed with a gentle $\left(<5^{\circ}\right)$ southerly dip along the coastline of the Bristol Channel. The rocks comprise limestonemarl and/or shale alternations with thicknesses of $150 \mathrm{~m}$ in South Wales (Wilson et al., 1990) and $175 \mathrm{~m}$ in North Somerset (Whittaker and Green, 1983). The alternations in Wales were deposited more proximal than of the ones in Somerset. The investigated successions in Wales and Somerset are probably not synchronous, but belong to the same formation. However, the morphological appearance (from limestone-dominated to marl-dominated) varies predominately between the two study areas (Wales and Somerset, UK).

The origin of limestone-marl alternations (LMA) of the Blue Lias Formation of south-west Britain has been extensively studied (e.g. Hallam, 1960; Weedon, 1986; Sheppard et al., 2006). Although most authors agree that the alternations are primary in origin and that the role of diagenesis has been subject of a long-standing controversy, because diagenesis complicates the picture of simple environmental changes (e.g. Hallam, 1960; Weedon, 1986; Sheppard et al., 2006; Bloos and Page, 2002). A brief review of the origin of these alternations will be described in the following paragraph.

An argumentation for primary sedimentation is that some carbonate mud was apparently supplied by coccoliths in zooplankton faecal pellets and clay minerals were supplied by rivers (Weedon, 1986). But after Weedon (1986) the most carbonate component in the Blue Lias Formation was neomorphised to microspar. Weedon (1986) agrees with Hallam (1960) that these changes in sediments reflect cyclic changes in bottom-water oxygenation levels combined with changes in the clay-to carbonate mud ratio. Hallam (1960) proposed that $\mathrm{CaCO}_{3}$ has to be segregated during early diagenesis to generate the nodular structures in this area. The Blue Lias Formation in Somerset shows sedimentary cycles comprising from the base upwards bituminous shale, marl, limestone and marl (Bloos and Page, 2002; Fig. 4.2B). The sediments were originally homogeneous and the cycles may have comprised at first only two types of sediments: (1) finely laminated bituminous shales, characterised by fissile organic-rich layers with discrete, low-diversity horizons of benthos (Wignall and Hallam, 1991) which grading upwards into (2) aerated mud sediments (Bloos and Page, 2002). These cycles in combination with variations in burrowing intensity and benthic fossil diversity indicates strong variations in dysaerobic and anaerobic conditions of the bottom-water in a rapidly subsiding basinal area (Wignall and Hallam, 1991; Hesselbo et al., 2004; Fig. 4.2B). The limestone beds were generated by late cementation of levels in this mud sediment with 
slightly higher $\mathrm{CaCO}_{3}$-content (Bloos and Page, 2002). Sheppard et al. (2006) interpreted the limestone-marl contacts in LMA of the Blue Lias Formation in Wales as primary sedimentary bedding planes, while they interpret the marl-limestone contacts, as pseudo-bedding planes that originated from the diagenetic differentiation of original lime mud. The interpretation that limestone-marl contacts represent primary sedimentary bedding planes is mainly based on observed hardgrounds with encrusting macrofossil assemblages and trace fossils at the surface of the limestones, indicating sedimentation breaks (i.e. omission surfaces; Sheppard et al., 2006; Flügel, 2010). 


\section{-Chapter 5-}

\section{Methods overview}

The study applied an interdisciplinary approach combining different conventional methods in structural geology and sedimentology with those from petrophysics in order to gain a better understanding of the role of facies, diagenesis, and petrophysical properties on fracture arrest and propagation in layered rocks.

\subsection{Structural geological approach}

4010 fractures in six sections with lengths of $15 \mathrm{~m}$ and heights depending on accessibility of 2-3 $\mathrm{m}$ were measured in detail. The measured sections were selected because of their variation in LMA (from limestone- to marl-dominated) and maximum possible distance to faults in the area. The vertical extension of fractures was determined through one or more than one layer using a modified scan-line method (Afşar et al., 2014; see chapter 6.4 for details). Since for short fractures measurement errors (in particular of strike) increase progressively, only fractures with lengths larger than $7 \mathrm{~cm}$ are included in the data set. Within beds or interbeds with thicknesses smaller than $7 \mathrm{~cm}$, this threshold was lowered to $4 \mathrm{~cm}$. The approach of the modified scan-line method allows the measurement of even small fractures with small apertures $(<0.1 \mathrm{~mm})$, which are below the detection limits of digital technologies (e.g. light or laser detection and ranging). Seven different fracture traces were classified into two different fracture types, distinguishing fractures restricted to individual beds ('stratabound') from fractures propagated into adjacent beds or interbeds crossing at least one lithological contact ('non-stratabound') (see chapter 6 for details; Fig. 5.1A,B). In chapter 7, fractures terminating at lithological contacts ('fracture terminations') or fractures extending through either lithological contact at top or base or both ('fracture crossings') in a purely descriptive sense were distinguished (Fig. 5.1A,C). 


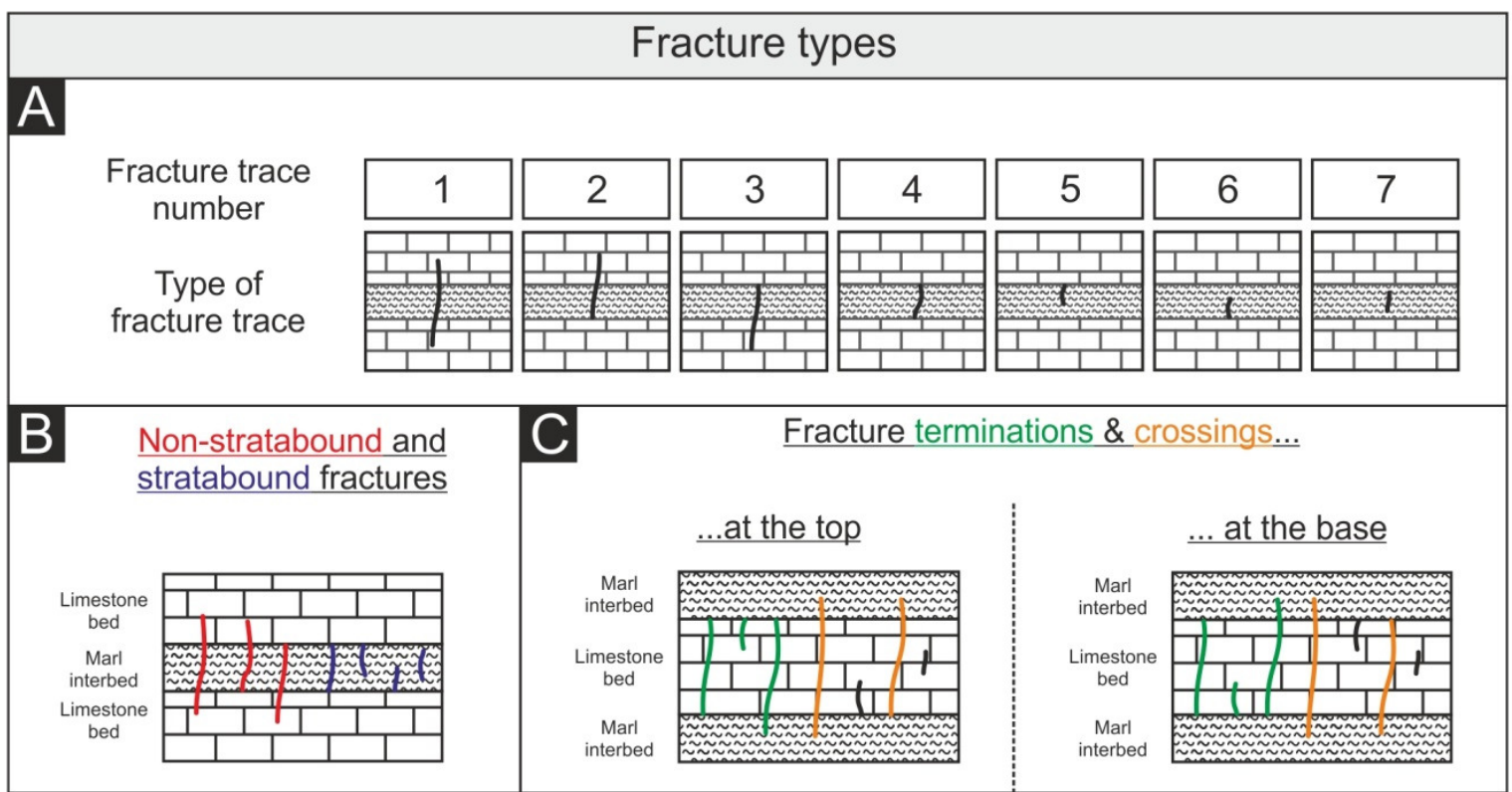

Figure 5.1: $\quad$ A) Seven different fracture traces with fracture trace numbers for each layer were mapped; B) In chapter 6 the vertical fracture extension was distinguished in nonstratabound fractures, which are propagating into the adjacent layer (crossed at least one bedding plane) and stratabound fractures, which are restricted to single layers; C) In chapter 7 additionally the fracture arrest at lithological contacts were mapped, distinguishing fracture terminations at and crossings through each contact.

\subsection{Sedimentological field techniques and measurements}

Since variations in fracture distribution may be related to sedimentary characteristics, sedimentological field observations, thin sections analysis, measurements of $\mathrm{CaCO}_{3}$ and $\mathrm{C}_{\text {org }}$ contents were performed for each bed and interbed and SEM analyses were conducted on selected beds and interbeds.

Sedimentological field work included the measurement of six detailed sedimentary sections and the documentation of important sedimentary features in bed-scale. Petrographic analyses of 59 thin sections were after Dunham (1962) classified and specific features in rock textures, such as compacted or uncompacted bioturbation tubes, orientation of different bioclasts and neomorphised recrystallised calcites were focussed. Petrographical tools included observation of polished slabs and thin sections (e.g. transmitted and polarised light microscopy). Staining techniques on selected thin sections included the use of Alizarine red $\mathrm{S}$ for differentiating dolomite and calcite by staining calcite red, and potassium ferricyanid for differentiating ferroan and non-ferroan carbonates by staining iron-rich calcite and dolomite bluish (Flügel, 2010; and references therein). 
To determine the $\mathrm{CaCO}_{3}$ and $\mathrm{C}_{\text {org }}$ contents, 64 samples were homogenised by way of grinding and were analysed for bulk C/N/S using a Hekatech Euro EA Elemental Analyser.

SEM analyses were conducted in order to investigate diagenetic features on a micrometrescale, with special emphasis on chemical processes (i.e. evidences for solution, compaction etc.). 16 samples in three selected sections were etched for SEM analyses three minutes (limestones) and five minutes (marls) with $5 \%$ ethylenediaminetetraacetic acid (EDTA) (see Chapter 8.2 for details). Gold-palladium spattered samples were examined with the SEM TESCAN Vegallxmu and ZEISS LEO 1530 Gemini. Additionally, an energy-dispersive X-ray spectrometer (EDX) Oxford Inca coupled to the SEM was used for elemental analyses.

\subsection{Petrophysical measurements}

Since mechanical rock properties are directly related to fracture distribution, Young's modulus, uniaxial compressive and tensile strengths were determined for representative rock samples. Because of the high fragility of marl interbeds, sampling was limited by only two different limestone lithologies (well-bedded and semi-nodular limestone).

To consider variations of strength and stiffness due to rock heterogeneities, a minimum of six specimens for each lithology were measured parallel and perpendicular to sedimentary bedding for both uniaxial compressive and tensile strength measurements. For the specimens, cylindrical cores with a diameter of $40 \mathrm{~mm}$ were drilled and both ends of the core were grinded plan-parallel.

The specimens for the uniaxial compression test were prepared according to ISRM (2007) with a length-diameter-ratio (L/D) of 2:1 (i.e. $80 \mathrm{~mm}$ in length and $40 \mathrm{~mm}$ in diameter). During a constant loading rate of $0.5 \mathrm{MPa} / \mathrm{s}$, stress and strain were recorded until failure of the specimens occurred. Young's moduli are a measure of the elasticity (i.e. recoverable deformation under load) of rock material, receiving from the stress-strain curve after a preload of about $70 \%$ of UCS.

The specimens for the Brazilian test (tensile strength measurements) had, according to ISRM (2007), a diameter of $40 \mathrm{~mm}$ and a length of $20 \mathrm{~mm}$. The specimens reached the tensile strength when failure took place after a constant loading rate of $30 \mathrm{~N} / \mathrm{s}$.

Rock hardness was measured in the field with a portable electronic rebound hardness testing device (EquotipProceq) in order to estimate the unconfined compressive strength (UCS; Meulenkamp and Grima, 1999). The UCS were calculated given by (Meulenkamp and Grima, 1999), 


$$
\operatorname{UCS}_{\text {(calc.) }}=1.75 * 10^{-9} \mathrm{~L}^{3.8}
$$

where L is the Eqoutip value. For statistical reasons, 30 measurements for each bed and interbed were taken in all sections. Because of hardness differences between limestones and marls, different sensors for each lithology were used. Sensors standard type (D) with impact energy of $11 \mathrm{Nmm}$ for stiff limestone beds and standard type (C) with impact energy of $3 \mathrm{Nmm}$ for soft marl interbeds were used.

Effective porosity $(\Phi)$, bulk density ( $\left.\rho_{\text {bulk }}\right)$ and matrix density $\left(\rho_{\mathrm{r}}\right)$ were determined for selected samples of each lithology based on the Archimedes Principle by measuring sample weights under dry, wet and water-soaked (buoyancy) conditions (cf. Hoffmann, 2006). 


\title{
-Chapter 6-
}

\section{How facies and diagenesis affect fracturing of limestone beds and reservoir permeability in limestone-marl alternations}

\author{
Filiz Afşar ${ }^{\text {a,* }}$, Hildegard Westphal ${ }^{\text {b, c }}$, Sonja L. Philipp ${ }^{\text {a }}$ \\ ${ }^{a}$ University of Göttingen, Geoscience Centre (GZG), Structural Geology and Geodynamics, Goldschmidtstraße \\ 3, D-37077 Göttingen, Germany \\ ${ }^{b}$ Leibniz Centre for Tropical Marine Ecology GmbH (ZMT), Biogeochemistry and Geology, Geoecology and \\ Carbonate Sedimentology, Fahrenheitstraße 6, D-28359 Bremen, Germany \\ ${ }^{c}$ University of Bremen, Department of Geosciences, Klagenfurter Straße, D-28359 Bremen, Germany
}

*Correspondence: filiz.afsar@geo.uni-goettingen.de

Marine and Petroleum Geology (2014) 57, 418-432

\begin{abstract}
Facies and diagenetic heterogeneities in carbonate reservoir rocks affect both, fracture distribution and fracture permeability. Many studies focused on fracture patterns in limestonemarl alternations, as e.g. fluid flow models, are based on laterally continuous beds. Here we examine 4010 fractures in multiple layers of limestone-marl alternations using a modified scan-line method. The studied successions belong to the Blue Lias Formation (HettangianSinemurian), exposed on the coast of the Bristol Channel, United Kingdom. We combine methods of sedimentology and structural geology with rock physics to gain a better understanding of the role of facies, diagenesis and petrophysical properties (tensile and compressive strength, hardness, porosity) on the distribution of fractures (fracture orientation, density, spacing and height). Fracture distribution varies significantly despite similar bed thicknesses, indicating that planar bedding planes (i.e. well-bedded limestones) and beds with bedding plane irregularities (i.e. semi-nodular limestones) must be distinguished. Seminodular limestones show higher percentages of non-stratabound fractures $(67 \%)$ while they are more stratabound in well-bedded limestones (57\%). Additionally, beds with variable bed thicknesses (in scale of $15 \mathrm{~m}$ long beds) exhibit a wide range of fracture spacing, whereas fractures in beds with more continuous bed thicknesses are more regularly spaced. Considering all lithologies, the percentage of non-stratabound fractures increases proportionally with $\mathrm{CaCO}_{3}$ content. Three subsections studied in detail reveal different main sedimentological and diagenetic features (from early lithified over differentially compacted to physically compacted). All of them are characterised by dissimilar percentages of stratabound and non-stratabound fractures in limestones and marls. Our findings demonstrate that the distribution of fractures in individual well-bedded limestones is not necessarily representative for successions of limestone-marl alternations; multiple layers should therefore be studied in outcrop analogues as basis for fluid flow models of reservoirs composed of such lithologies.
\end{abstract}




\subsection{Introduction}

Fluid flow in many reservoirs is largely controlled by the permeability of their fracture networks ('fractured reservoirs'; cf. Nelson, 1985). Flow, however, does not take place along a particular fracture network unless the fractures are interconnected (i.e. above the percolation threshold; cf. Stauffer and Aharônî, 1994). Reservoirs in many cases are characterised by mechanical layering, i.e. mechanical property changes between layers ('layered naturally fractured reservoirs'; cf. Aguilera, 2000). Many reservoirs for petroleum, natural gas, ground or geothermal water are both fractured and layered reservoirs. Particularly, limestone-marl alternations could contain oil-shale beds, where hydrocarbons are generated, stored and trapped in the same layer. Oil-shale beds of the Blue Lias Formation, for example, crop out in Kilve (Somerset) and also the Kimmeridge Clay of onshore eastern and southern England contains oil-shale beds (Harvey and Gray, 2011). In multi-layered, fractured reservoirs the fracture permeability from layer to layer can vary considerably (Aguilera, 2000). Generally, ignoring the variation in fracture permeability between layers of a multi-layered reservoir can lead to overestimation of overall reservoir permeability (Aguilera, 2000).

Much of the variation in fracture permeability between layers is caused by differences in fracture distribution, mainly described by three related parameters: (1) fracture orientation (strike and dip); (2) fracture spacing in individual layers, commonly defined as the horizontal distance between two adjacent fractures (e.g. Narr and Suppe, 1991), and fracture density (number of fractures per metre); (3) fracture persistence, for example, fracture height, determining the vertical extension through one or many layers. In the following we therefore use 'fracture distribution' as a general term encompassing fracture orientation, spacing/density and height.

In limestone-marl alternations (LMA), the bedding provides mechanical anisotropies that control fracture distribution (e.g. Helgeson and Aydin, 1991; Larsen et al., 2010). Fracture studies investigating layered or bedded rock successions, as well as the resulting models of fracturing and fluid flow in reservoirs, typically use the simplification of laterally continuous beds (e.g. Schöpfer et al., 2011; Gudmundsson et al., 2012; Philipp et al., 2013; see chapter 9 for details). This simplification, however, may lead to erroneous conclusions regarding fracture distribution in a reservoir and thus also inaccurate predictions of fluid flow. A wellknown example of LMA is the Blue Lias Formation of the Bristol Channel area in the United Kingdom. The origin and evolution of fractures in the Blue Lias in this area have been studied 
extensively (e.g. Caputo, 1995; Rawnsley et al., 1998). Nevertheless, a detailed study concerning the effects of facies and diagenesis on fracture distribution has as yet not been undertaken.

The principal aim of this paper is to improve our understanding of fracture distribution in layered rocks, using the Blue Lias as an example, also considering planarity of bedding planes and lateral variations in the bed thicknesses of limestone beds. For this purpose we combine methods from sedimentology and structural geology with those from petrophysics to study six sections with a wide range of morphological variations from limestone-dominated to marldominated alternations, on the Welsh and English coasts of the Bristol Channel.

\subsection{Fracture distribution - state of the art}

Depending on the relative displacement across the fracture plane, all fractures can be characterised as either shear fractures or extension fractures (e.g. Gudmundsson, 2011). For shear fractures the relative displacement is parallel to the fracture plane (e.g. Gudmundsson, 2011). In contrast, for extension fractures the relative displacement is perpendicular to the fracture plane (e.g. Narr and Suppe, 1991). According to common hypotheses, extension fractures form when the effective tensile stress reaches the tensile strength of the rock, either during uplift, with or without erosion, via direct extension such as is observed in rift zones (both processes result in tension fractures), or via fluid overpressure (resulting in a hydrofracture; Price, 1966; Gudmundsson, 2011). As it is often difficult to distinguish tension fractures and hydrofractures in the field since in many hydrofractures the fluid may disappear after the fracture has formed, the general term extension fracture or joint is commonly used. The term 'joint' is used in field studies for a fracture with only slight fracture-normal displacement; however, some may also exhibit a small displacement parallel to the fracture plane (Narr and Suppe, 1991; Gudmundsson, 2011). Joints in stiff beds are generally oriented perpendicular to bedding planes and are evenly distributed (e.g. Gudmundsson, 2011). Since the present study concentrates on fracture distribution in layered rocks, the mechanism responsible for fracture formation is not discussed in detail. In addition, because some fractures in marls may also be sheared, we use the general term 'fractures'.

Orthogonal fracture systems consist of two perpendicular fracture sets. In part of the literature one set is interpreted as an early 'systematic fracture set' and the other as a later 'nonsystematic fracture set', with the latter also referred to as 'cross joints' between the former 
(e.g. Hodgson, 1961, Hancock, 1985; Gross, 1993; Bai et al., 2002; Reber et al., 2010). The terms systematic fracture set and cross joints imply a chronology, with systematic joints being formed earlier than cross joints. According to Caputo (1995), however, this usage is misleading because geometric relationships indicate coeval joint sets so that many 'cross joints' are rather 'systematic joints'. Such fracture chronology is not of interest in this study; we therefore use the terms 'systematic fracture set' and 'non-systematic fracture set' without implying any chronological order of fracture formation.

The density or spacing of fractures commonly varies with structural position or lithology, in particular with rock mechanical properties (Aguilera, 1995). Several studies document increasing fracture spacing and decreasing fracture density with increasing bed thicknesses (e.g. Bogdanov, 1947; Ladeira and Price, 1981; Narr and Suppe, 1991; Wu and Pollard, 1995). However, it is still controversially discussed whether the relationship between fracture spacing and bed thicknesses is linear (e.g. Price, 1966; Hobbs, 1967; Sowers, 1972) or nonlinear (e.g. Norris, 1966; Mastella, 1972; Mandal et al., 1994).

Other studies have found a poor correlation between fracture spacing and sedimentary layer thicknesses, with a stronger relationship instead observed between fracture spacing and the thicknesses of 'fracture units', the latter being defined as groups of sedimentary beds with homogeneous fracture patterns (e.g. Laubach et al., 2009; Boro et al., 2013). Applying these correlations to natural fracture systems in order to predict fracture permeabilities is difficult for two main reasons.

First, there are typically two or more fracture sets within a section. The spacing of each fracture set may be different, with the different fracture sets affecting each

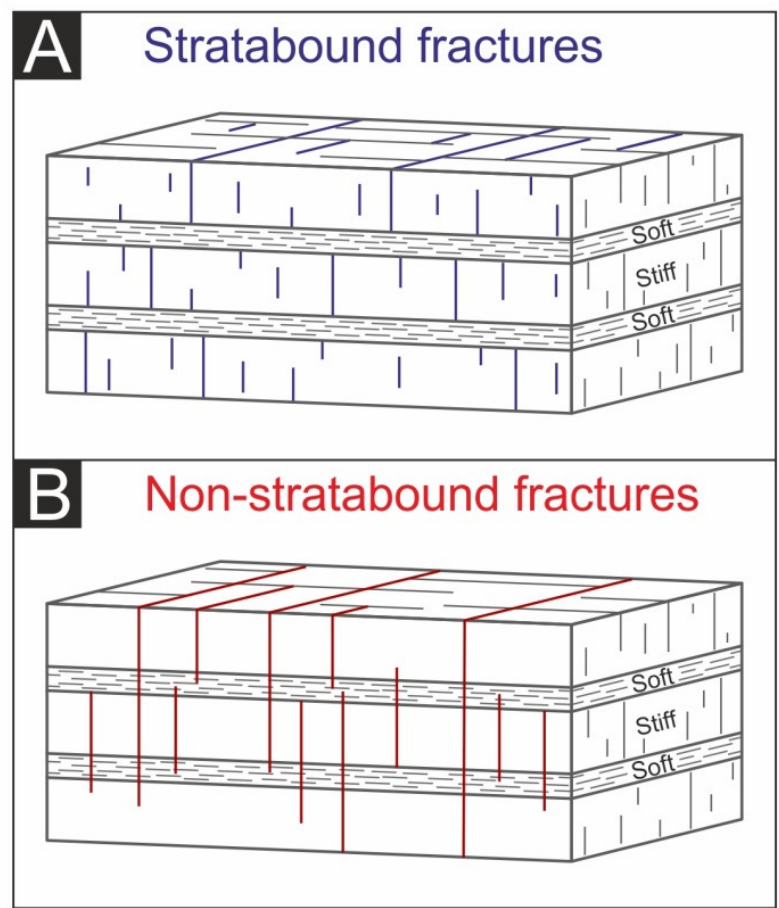

Figure 6.1: A) Stratabound fractures are confined to individual beds; B) Nonstratabound fractures propagate through more than one layer (after Odling et al., 1999). 
other. Second, clear correlations apply only to tension fractures. For hydrofractures, which are driven by fluid overpressure, fracture spacing may instead be much lower (e.g. Gudmundsson, 2011).

To describe vertical fracture propagation the fracture height was measured, with two fracture types distinguished; Fractures restricted to single beds are referred to as stratabound fractures, whereas for non-stratabound fractures, layering does not affect fracture growth (Odling et al., 1999; Fig. 6.1). Regular spacing is particularly common for stratabound joints (Odling et al., 1999). For non-stratabound joint systems, however, joint sizes cover a wider range and spacing may exhibit greater variation (Odling et al., 1999). Lithological contacts often coincide with mechanical contrasts and therefore act as barriers to fracture propagation. This is also the case in LMA, where limestone beds commonly exhibit higher stiffness (Young's moduli) than marls (in the following referred to as 'interbeds'; cf. Bell, 2000). Joints therefore tend to be largely confined to single beds, leading to the development of 'stratabound' joint systems (Odling et al., 1999).

\subsection{Geological setting and study areas}

The study areas are located on the northern (Wales) and the southern margin (Somerset) of the Bristol Channel (Fig. 6.2A). The structure of the Bristol Channel Basin (BCB) is commonly interpreted as a WNW-ESE-striking half-graben with a south-dipping listric normal reactivated Variscan thrust fault (e.g. van Hoorn, 1987). Development of the BCB started during the Permo-Triassic Rifting with N-S extensional movement, which reactivated the Hercynian thrust zone (van Hoorn, 1987). During the late Triassic and Jurassic, further NESW to NNE-SSW extension took place (Dart et al., 1995; Nemčok et al., 1995). Rifting continued until the Lower Cretaceous (Aptian), when the maximal burial depth was reached (Nemčok et al., 1995; and references therein). Vitrinite reflectance data indicate that the Liassic source rocks were buried to at least $2.25 \mathrm{~km}$, and possibly to as deep as $3.2 \mathrm{~km}$ (Nemčok et al., 1995; and references therein). The basin was inverted during the late Cretaceous and early Tertiary $\mathrm{N} \pm \mathrm{S}$ compression associated with Alpine orogenesis (Dart et al., 1995; Nemčok et al., 1995).

Sedimentation of the Mesozoic rocks took place in a rift-related basin during regional subsidence initiated during the rifting of the Palaeozoic basement at the end of the Variscan orogeny (cf. Cope, 2006). The rocks of all investigated sections belong to the Blue Lias 
Formation (Lower Jurassic, Hettangian and Sinemurian), exposed at the coast of the Bristol Channel.

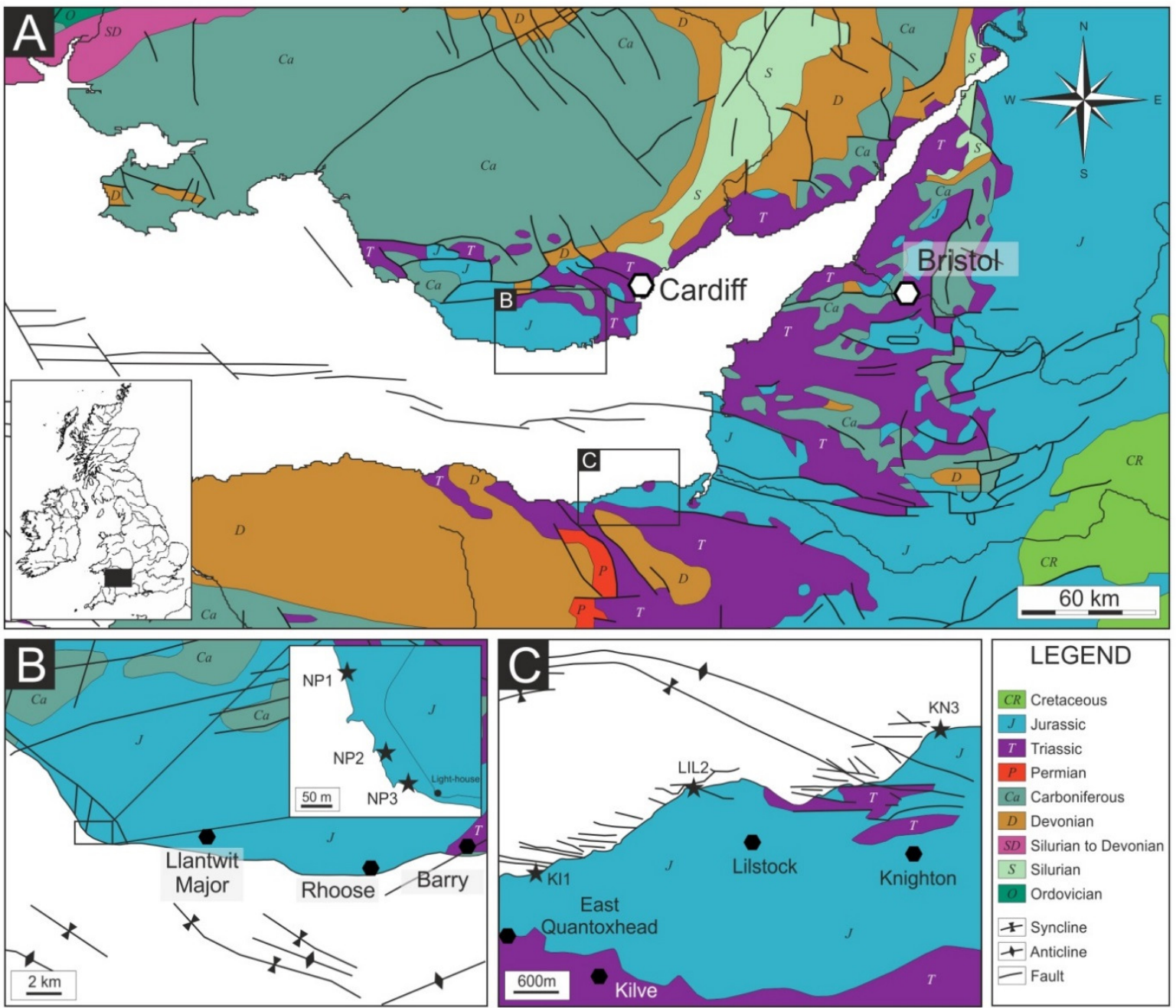

Figure 6.2: A) Geological map of the Bristol Channel area (Tappin et al., 1994) with the two study areas (rectangles B and C); B) Location of sections NP1-3 in Wales (modified after Rawnsley et al., 1998); C) Location of sections KI1, LIL2 and KN3 in Somerset (modified after Belayneh and Cosgrove, 2010).

The alternations comprise limestone-marl and/or shale alternations with thicknesses of $150 \mathrm{~m}$ in South Wales (Wilson et al., 1990) and $175 \mathrm{~m}$ in North Somerset (Whittaker \& Green, 1983). The succession represents the typical hemipelagic offshore shelf facies of a shallow sea that was part of an epeiric ocean in the area of NW Europe (Northern Tethys; cf. Cope, 2006). The origin of LMA of the Blue Lias Formation in south-west Britain has been studied extensively (e.g. Hallam, 1960; Weedon, 1986; Sheppard et al., 2006). Hallam (1960) proposed that the Blue Lias rhythm is primary in origin and is the result of repeated oscillation, but there was also an early diagenetic segregation of $\mathrm{CaCO}_{3}$ leading to the 
formation of nodular structures. Sheppard et al. (2006) interpreted the limestone-marl/shale contacts and the randomly distributed omission surfaces (i.e. hardgrounds with encrusting macrofossil assemblages) as proxies for sedimentary bedding and the marl/shale-limestone contacts as pseudo-bedding planes, with the alternation of limestones and marls/shales originating from the diagenetic differentiation of lime mud.

The major fault systems along the basin margins were active during the Mesozoic N-S extension (e.g. Kamerling, 1979; van Hoorn, 1987). Many normal faults were reversereactivated during the late Cretaceous and early Tertiary $\mathrm{N} \pm \mathrm{S}$ compression (e.g. Dart et al., 1995; Nemčok et al., 1995), with reverse faulting more prevalent on the southern (Somerset) than on the northern margin (Wales) of the BCB (Nemčok et al., 1995). Lilstock Beach in Somerset, for example, is divided into several fault blocks by normal faults (Dart et al., 1995). The rocks in Wales are mainly affected by a series of conjugated strike-slip faults which cut the rocks with trends of about $\mathrm{N} 160^{\circ} \pm 10^{\circ}$ (Petit et al., 1999). The major fracture set parallel to the strike-slip faults was formed during the course of a late Cretaceous-early Miocene compression, in which the minimum effective principal stress $\left(\sigma_{3}\right)$ was horizontal and perpendicular to the older $\mathrm{N} 170^{\circ}$-striking fracture sets associated with the strike-slip faults (Pascal et al., 1997).

\subsection{Field and laboratory methods}

Sections NP1-3 are located at the northern margin (Fig. 6.2B) and KI1, LIL2 and KN3 at the southern margin (Fig. 6.2C) of the Bristol Channel. The sections were selected because of their strong morphological variations (from limestone- to marl-dominated) and maximum possible distance to faults in the area (2-15 m; Tab. 6.1).

\begin{tabular}{|c|c|c|c|c|}
\hline Section & $\begin{array}{c}\text { Distance } \\
\text { to next } \\
\text { fault }[\mathrm{m}]\end{array}$ & $\begin{array}{c}\text { Fault throw } \\
{[\mathrm{m}]}\end{array}$ & $\begin{array}{c}\text { Fault } \\
\text { strike }\end{array}$ & $\begin{array}{c}\text { Strike of main } \\
\text { fracture set }\end{array}$ \\
\hline \hline NP1 & 4 & 2.6 & $\mathrm{~N}-\mathrm{S}$ & $\mathrm{E}-\mathrm{W}$ \\
\hline NP2 & 15 & 1.9 & $\mathrm{~N}-\mathrm{S}$ & $\mathrm{E}-\mathrm{W}$ \\
\hline NP3 & 13 & 2 & $\mathrm{~N}-\mathrm{S}$ & $\mathrm{N}-\mathrm{S}$ \\
\hline KI1 & 2 & 2 & $\mathrm{E}-\mathrm{W}$ & NNW-SSE/NNE-SSW \\
\hline LIL2 & 14.5 & 0.6 & $\mathrm{~N}-\mathrm{S}$ & $\mathrm{N}-\mathrm{S}$ \\
\hline KN3 & 7.5 & 0.2 & $\mathrm{NW}-\mathrm{SE}$ & $\mathrm{NW}-\mathrm{SE}$ \\
\hline
\end{tabular}

Table 6.1: Summary of spatial orientation of fracture sections and adjacent faults: Distance from the section to the closest fault, fault throw, fault strike and strike of main fracture set. 

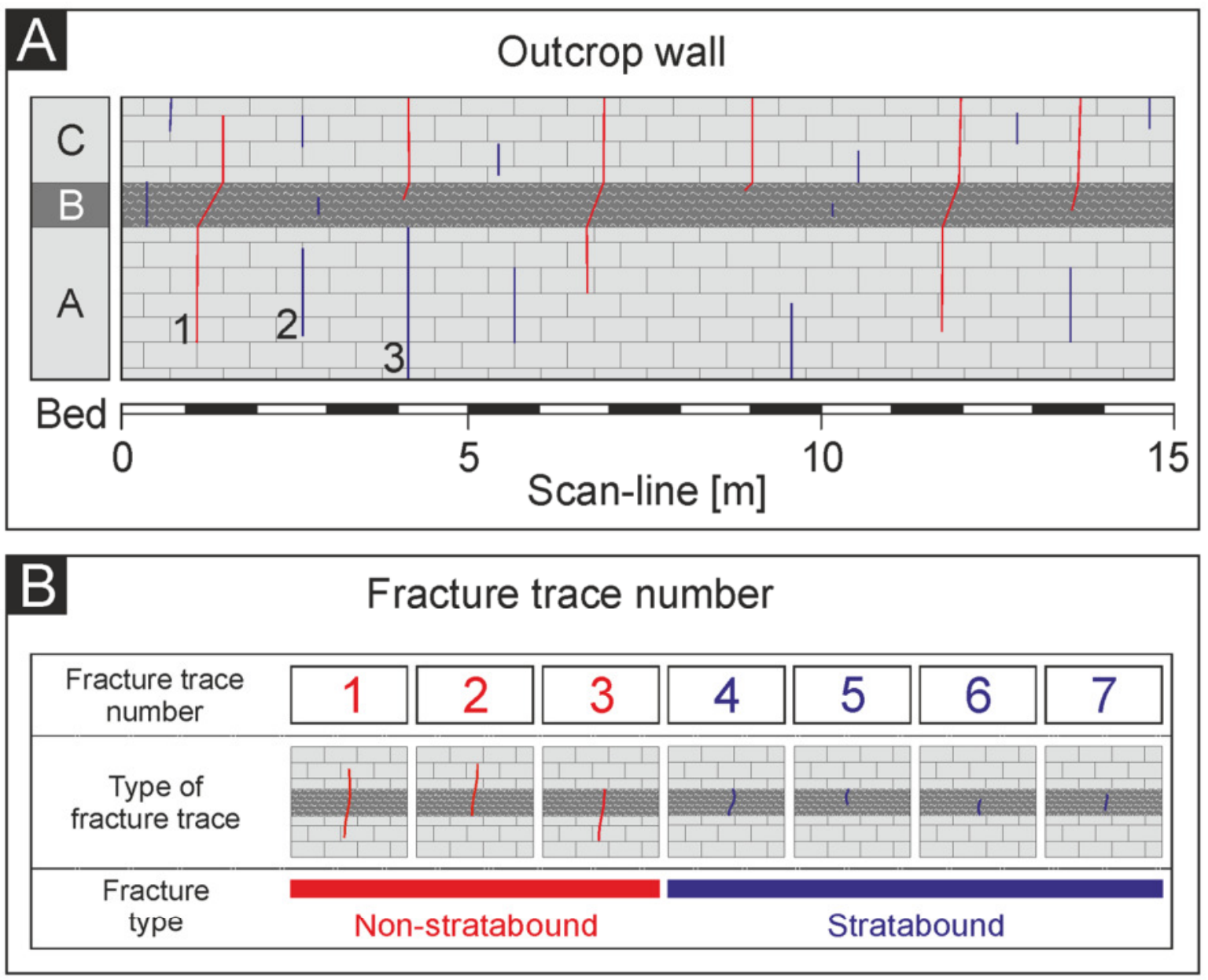

C Schematic modified scan-line method
\begin{tabular}{|c|c|c|c|c|c|c|c|c|}
\hline $\begin{array}{c}\text { Fracture } \\
\text { Number }\end{array}$ & $\begin{array}{c}\text { Bed/ } \\
\text { Interbed }\end{array}$ & $\begin{array}{c}\text { Bed } \\
\text { thickness } \\
{[\mathrm{cm}]}\end{array}$ & $\begin{array}{c}\text { Scan-line } \\
{[\mathrm{cm}]}\end{array}$ & $\begin{array}{c}\text { Fracture } \\
\text { Strike }\end{array}$ & $\begin{array}{c}\text { Fracture } \\
\text { Dip }\end{array}$ & $\begin{array}{c}\text { Fracture } \\
\text { height } \\
\text { per bed } \\
{[\mathrm{cm}]}\end{array}$ & $\begin{array}{c}\text { Fracture } \\
\text { height } \\
{[\mathrm{cm}]}\end{array}$ & $\begin{array}{c}\text { Fracture } \\
\text { trace } \\
\text { number }\end{array}$ \\
\hline 1 & $\mathrm{~A}$ & 240 & 110 & 180 & 88 & 181 & & 5 \\
\hline 1 & $\mathrm{~B}$ & 68 & $\cdots \cdots$ & 185 & 62 & 70 & \multirow{2}{*}{352} & 1 \\
\hline 1 & $\mathrm{C}$ & 132 & $\cdots \cdots$ & 182 & 84 & 103 & & 6 \\
\hline 2 & $\mathrm{~A}$ & 245 & 275 & 178 & 89 & 138 & 138 & 7 \\
\hline 3 & $\mathrm{~A}$ & 238 & 410 & 189 & 85 & 238 & 238 & 4 \\
\hline
\end{tabular}

Figure 6.3: Schematic illustration of the modified scan-line method. A) The scan-line is oriented parallel to the outcrop wall and thus essentially perpendicular to one fracture set; B) Beds are named in alphabetical order. Each fracture was classified with respect to its path in every bed; e.g. a fracture trace number of 4 means that the fracture starts at the base of a bed and stops at the top; C) Local bed thicknesses were measured directly at every fracture where fracture parameters and fracture trace numbers were documented. 
A total of 4010 fractures were measured using a modified scan-line method (Fig. 6.3). This approach allows the measurement of even small fractures with small apertures $(<0.1 \mathrm{~mm})$ and which are thus below the detection limits of digital technologies (e.g. light or laser detection and ranging). Whereas the length of each scan-line was $15 \mathrm{~m}$, the height of the sections varied depending on accessibility (Fig. 6.3A).

The orientation of each scan-line was parallel to the respective outcrop wall and was thus mostly perpendicular to one fracture set. Each fracture was followed over multiple beds; each bed was lettered and the fracture trace coded with seven different numbers (Fig. 6.3B). Thereby we distinguished fractures restricted to an individual bed ('stratabound') from those not restricted, i.e. the fracture propagated into an adjacent bed or interbed crossing at least one lithological contact ('non-stratabound'; Fig. 6.3B). Since for short fractures measurement errors (in particular of strike) increase progressively, only fractures with lengths larger than 7 $\mathrm{cm}$ are included in the data set. Within beds or interbeds with thicknesses smaller than $7 \mathrm{~cm}$ this threshold was lowered to $4 \mathrm{~cm}$. Geometric fracture parameters were acquired (strike, dip, height) as well as the local bed thickness at each fracture position (Fig. 6.3C).

Table 6.2 summarises the average bed thicknesses of each bed or interbed as well as the number of fractures measured. The fracture densities (number of all fractures per metre) were calculated of each bed or interbed of all six sections, the spacing of fractures (horizontal distance between two adjacent fractures with fracture trace numbers 1 to 4 ) were measured in three sections.

At each investigated section, sedimentary characteristics were documented and the respective facies examined in detail. Each bed was sampled for subsequent petrographic examinations (oriented thin-sections) and geochemical analyses, including $\mathrm{CaCO}_{3}$ and $\mathrm{C}_{\text {org }}$ measurements, conducted using a Hekatech Euro EA Elemental Analyser (CNS).

Rock hardness was measured in the field via a portable electronic rebound hardness testing device (EquotipProceq) in order to estimate the unconfined compressive strength (UCS; Meulenkamp and Alvarez Grima, 1999). To obtain statistically significant results, 30 measurements were taken per bed. Young's modulus, UCS and tensile strength were determined for representative rock samples. The UCS test was performed following DIN EN 1926, the Young's modulus was determined from the resulting stress-strain curve. Measurement of the tensile strength norm was carried out according to DIN 22024. Effective porosities were determined for selected samples based on the Archimedes Principle by 
measuring sample weights under dry, wet and water-soaked (buoyancy) conditions (cf. Hoffmann, 2006).

\begin{tabular}{|c|c|c|c|c|c|c|c|c|c|c|c|c|c|c|}
\hline \multirow{2}{*}{ Section } & & \multicolumn{13}{|c|}{ Beds/Interbeds } \\
\hline & & A & B & C & $\mathrm{D}$ & $E$ & $F$ & G & $\mathrm{H}$ & I & J & K & L & M \\
\hline \multirow{2}{*}{ NP1 } & $\begin{array}{l}\text { Bed thickness } \\
\quad[\mathrm{cm}]\end{array}$ & 15 & 10 & 7 & 18 & 13 & 11 & 6 & 11 & 5 & 17 & 20 & 8 & 13 \\
\hline & $\begin{array}{l}\text { Number of } \\
\text { fractures }\end{array}$ & 72 & 87 & 116 & 133 & 125 & 183 & 215 & 269 & 187 & 215 & 183 & 104 & 169 \\
\hline \multirow{2}{*}{ NP2 } & $\begin{array}{l}\text { Bed thickness } \\
\qquad[\mathrm{cm}]\end{array}$ & 49 & 5 & 6 & 27 & 5 & 6 & 5 & 11 & 5 & 26 & 5 & 15 & 37 \\
\hline & $\begin{array}{l}\text { Number of } \\
\text { fractures }\end{array}$ & 29 & 43 & 55 & 48 & 53 & 47 & 47 & 35 & 33 & 37 & 24 & 42 & 32 \\
\hline \multirow{2}{*}{ NP3 } & $\begin{array}{l}\text { Bed thickness } \\
{[\mathrm{cm}]}\end{array}$ & 7 & 6 & 16 & 16 & 23 & 24 & 7 & 10 & 8 & 12 & 13 & 11 & 一 \\
\hline & $\begin{array}{l}\text { Number of } \\
\text { fractures }\end{array}$ & 67 & 78 & 108 & 54 & 90 & 70 & 86 & 61 & 78 & 70 & 83 & 61 & 一 \\
\hline \multirow{2}{*}{$\mathrm{KI} 1$} & $\begin{array}{l}\text { Bed thickness } \\
\qquad[\mathrm{cm}]\end{array}$ & 28 & 14 & 23 & 29 & 16 & 7 & 43 & 11 & 12 & 5 & - & 一 & 一 \\
\hline & $\begin{array}{l}\text { Number of } \\
\text { fractures }\end{array}$ & 62 & 43 & 132 & 71 & 54 & 71 & 63 & 73 & 38 & 75 & - & 一 & - \\
\hline \multirow{2}{*}{ LIL2 } & $\begin{array}{l}\text { Bed thickness } \\
\quad[\mathrm{cm}]\end{array}$ & 18 & 9 & 21 & 6 & 19 & 5 & 27 & 13 & 7 & 11 & - & - & - \\
\hline & $\begin{array}{l}\text { Number of } \\
\text { fractures }\end{array}$ & 101 & 115 & 80 & 111 & 106 & 79 & 118 & 85 & 132 & 98 & - & - & 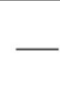 \\
\hline \multirow{2}{*}{ KN3 } & $\begin{array}{l}\text { Bed thickness } \\
\qquad[\mathrm{cm}]\end{array}$ & 36 & 16 & 18 & 11 & 11 & 21 & - & - & - & - & - & - & 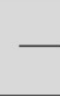 \\
\hline & $\begin{array}{l}\text { Number of } \\
\text { fractures }\end{array}$ & 143 & 119 & 156 & 113 & 141 & 117 & - & - & - & - & - & - & \\
\hline
\end{tabular}

Table 6.2: Summary of total fracture and bed thickness data collected for the six sections (number of fractures and average bed thickness of each bed).

\subsection{Results}

\subsubsection{Sedimentology and diagenesis}

Despite belonging to the same formation, both limestone beds and marl interbeds vary significantly between the two investigated study areas north and south of the Bristol Channel. For the limestone beds, two main lithologies were distinguished with regard to nodularity on bedding planes: (i) semi-nodular limestone beds with a wavy surface at the top and/or at the base and (ii) well-bedded limestone beds with relatively planar surfaces. Four main marl 
interbed lithologies were identified: (i) laminated calcareous marls, (ii) calcareous marls, (iii) laminated marls and (iv) regular marls.

Sections NP1 to 3 are located near the Nash Point lighthouse in South Wales. NP1 consists of four well-bedded and two semi-nodular limestone beds (Fig. 6.4). The respective beds have thicknesses ranging from 8 to $18 \mathrm{~cm}$ and are interbedded with 5 to $20 \mathrm{~cm}$ thick calcareous, laminated and regular marls (Fig. 6.4, Tab. 6.2). The section is slightly limestone-dominated. The thicknesses of limestones in NP2 range from 6 to $49 \mathrm{~cm}$, interbedded with 5 to $15 \mathrm{~cm}$ thick laminated calcareous, laminated and regular marls (Fig. 6.4, Tab. 6.2). The section is limestone-dominated. Some laminated calcareous marls pinch out laterally and the transition from limestone to laminated calcareous marl is sometimes gradual (Fig. 6.4).

$\underline{\text { NP3 }}$ comprises a greater number of semi-nodular limestone beds than well-bedded limestone beds (Fig. 6.4). The respective beds have thicknesses ranging from 6 to $24 \mathrm{~cm}$ and are interbedded with 7 to $23 \mathrm{~cm}$ thick calcareous and regular marls (Fig. 6.4, Tab. 6.2). The wellbedded and semi-nodular limestone beds in section $\underline{\mathrm{KI}}$, which is in the cliff near Kilve Pill in Somerset, vary in thickness from 12 to $16 \mathrm{~cm}$ (Tab. 6.2). The marl interbeds are very diverse and range from calcareous marls over regular marls to pure shales (Fig. 6.4), with the thicknesses of these beds varying from 8 to $42 \mathrm{~cm}$ (Fig. 6.4, Tab. 6.2). This section is dominated by shales/marls. The transition of one shale interbed (bed D; Fig. 6.4) to a seminodular limestone bed (bed E; Fig. 6.4) is punctually gradual and within bed C occurs as elliptical nodules enclosed by light marl (Fig. 6.4). The south-east dipping beds of section $\underline{\text { LIL2 }}$ are located near a Royal Navy observation tower in Somerset. In LIL2, thicknesses of well-bedded and semi-nodular limestone beds vary from 11 to $21 \mathrm{~cm}$ and are interbedded with 5 to $27 \mathrm{~cm}$ thick laminated calcareous, calcareous and laminated marls (Fig. 6.4, Tab. 6.2). Strata in this section are limestone-dominated. Section $\underline{\mathrm{KN} 3}$ is located between the Royal Navy observation tower and Hinkley Point power station in Somerset. The section comprises a greater number of well-bedded limestone beds (Fig. 6.4). The respective beds have thicknesses ranging from 11 to $21 \mathrm{~cm}$ and are interbedded with 11 to $36 \mathrm{~cm}$ thick calcareous and laminated marls (Fig. 6.4, Tab. 6.2). This section is marl-dominated.

Microfossils are rare throughout the entire succession. However, as revealed by field observations and thin-sections, some investigated strata contain rather more microfossils than others (Fig. 6.4). The fauna is diverse and includes ammonites, bivalves, echinoderms, gastropods and benthic foraminifera. Trace fossils such as Chondrites and large Thalassinoides burrow networks occur in some beds (Fig. 6.4). 

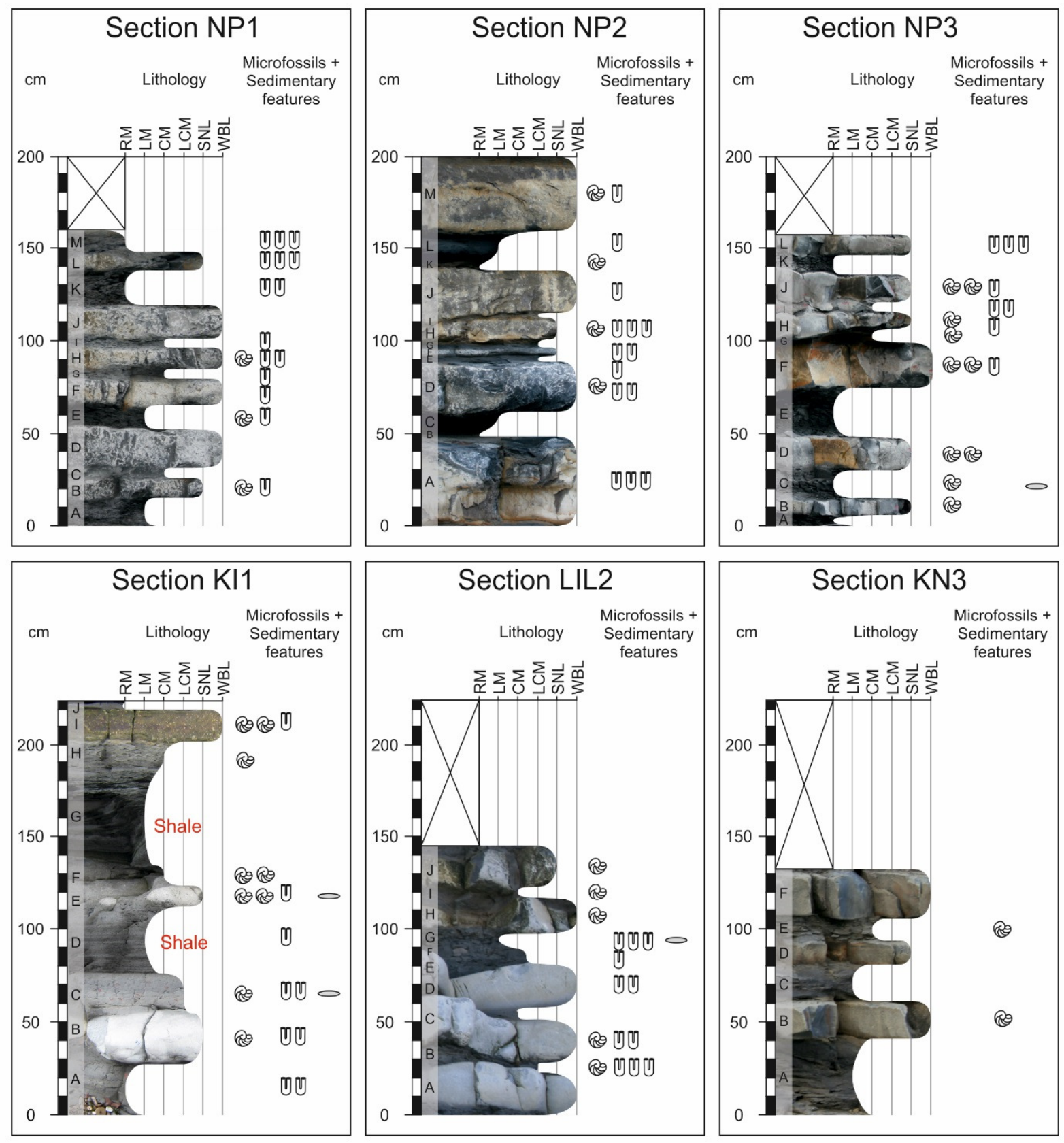

\begin{tabular}{|c|c|c|c|c|c|}
\hline \multirow{4}{*}{ 吕 } & \multicolumn{3}{|c|}{ Lithology } & \multicolumn{2}{|c|}{$\begin{array}{c}\text { Microfossils }+ \\
\text { Sedimentary features }\end{array}$} \\
\hline & \multirow[b]{3}{*}{ LCM Laminated calcareous marl } & $\mathrm{CM}$ & Calcareous marl & 89 & Microfossils \\
\hline & & LM & Laminated marl & (บ) & Bioturbation \\
\hline & & RM & Regular marl & $\infty$ & Concretion \\
\hline
\end{tabular}

Figure 6.4: Sedimentological sections; the break-off illustrates differences in lithology and is not scaled. The abundance of microfossils (gastropod-symbols; see key) and bioturbation (Usymbols) were determined based on thin-section analyses and field observations. Concretions (ellipse-symbols) were determined based on field observations only. 
Following Dunham (1962), the limestone beds can be classified as mud-supported carbonates, i.e. wackestones and, more significantly, mudstones. Micrite texture differs between the limestones of Wales and Somerset; whereas the latter is very homogeneous, the former consists of homogeneous clasts (probably due to bioturbation) and an inhomogeneous finegrained bioclastic micrite, resulting in an overall heterogeneous appearance (Fig. 6.5).
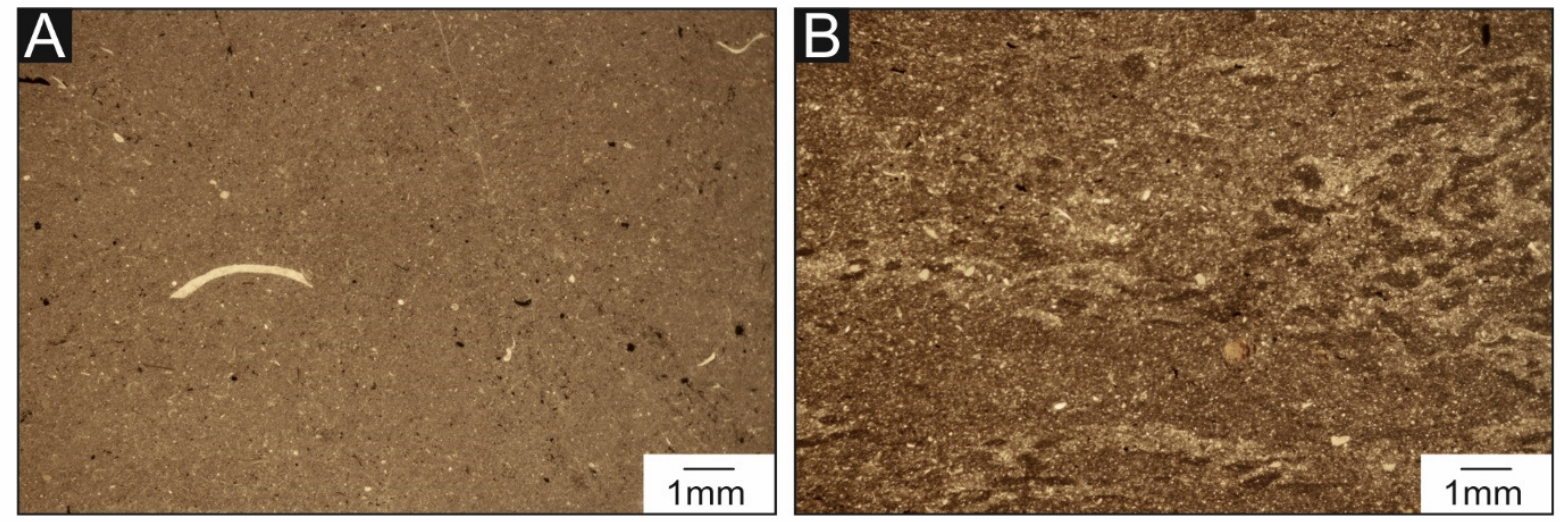

Figure 6.5: Two selected mudstone thin-sections. A) Homogeneous micrite of mudstones in Somerset; B) Darker clasts of a homogeneous (probably due to Chondrites) and an inhomogeneous fine-grained bioclastic micrite of mudstones in Wales.

Rocks in the investigated Somerset sections appear to be much more weathered than those in Wales since they frequently contain a red-brownish mineral, probably an iron oxide such as haematite. In order to investigate the impact of diagenesis we chose sections NP1-NP3 as representative examples, located in close vicinity $(<500 \mathrm{~m})$ which implies comparable depositional environments. Each selected section comprises a subsection of three or four limestone beds and two or three marl interbeds (with almost the same thicknesses) restricted by thicker marls (Fig. 6.6). The first subsection (of NP1) exhibits relatively planar limestone bed surfaces in which neither deformed trace fossils nor deformed fossils can be observed (Fig. 6.6A). Thin sections reveal undeformed bioturbation (i.e. Chondrites; Fig. 6.6A). In the subsection of NP2, whereas autochthonous and undeformed Pinna sp. fossils are preserved in the limestone beds, the Gryphaea sp. specimens in the marl interbeds are strongly deformed (Fig. 6.6B). The marl interbeds and limestone beds in the subsection of NP3 are differentiated more clearly compared to those in the NP2 subsection, with the former characterised by the presence of elliptical limestone nodules isolated within the marl interbeds (Fig. 6.6C). These well-lithified nodules within the weakly-lithified marl interbeds show signs of sliding, indicating movement (red marks; Fig. 6.6C). Bedding plane irregularities in subsection NP3 

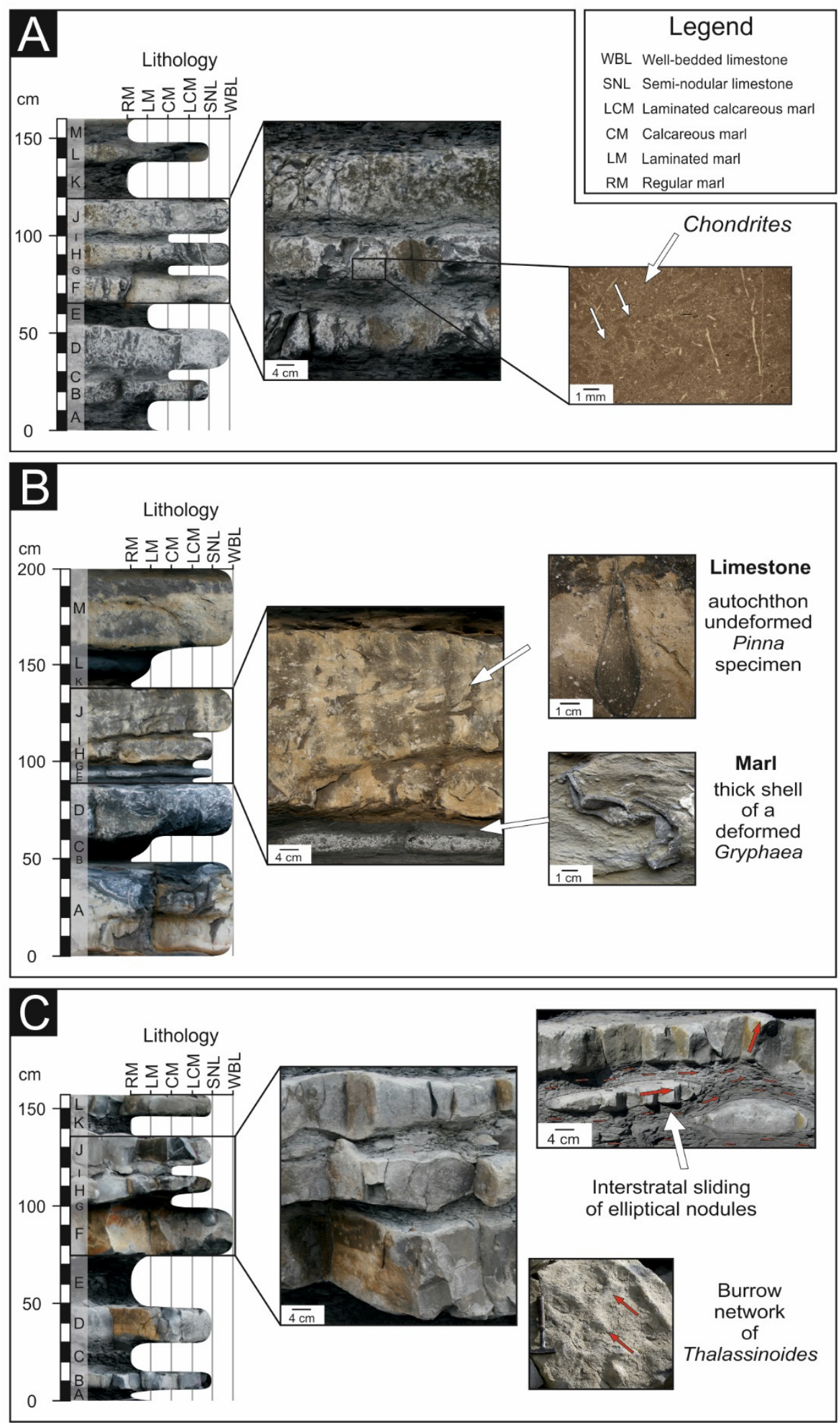

Figure 6.6: Three selected sections in Wales with field and thin-section observations. A) Section NP1 reveals well-bedded limestones and undeformed trace fossils (Chondrites); B) Section NP2 indicates differential compaction; C) Section NP3 reveals more semi-nodular limestones. 
are directly linked to trace fossils, particularly the branched burrow networks of Thalassinoides sp. (red arrows; Fig. 6.6C).

\subsubsection{Fracture distribution}

\section{$\underline{\text { Fracture orientation and adjacent faults }}$}

Although the measured fractures belong to orthogonal systems, only one fracture set was recorded in each section via the scan-line method; this has to be taken into account when evaluating the rose diagrams displayed in Figure 6.7. Even if fracture chronology is not of interest in the present study, knowledge of fracture orientation is important in evaluating the results of fracture density and spacing, because systematic

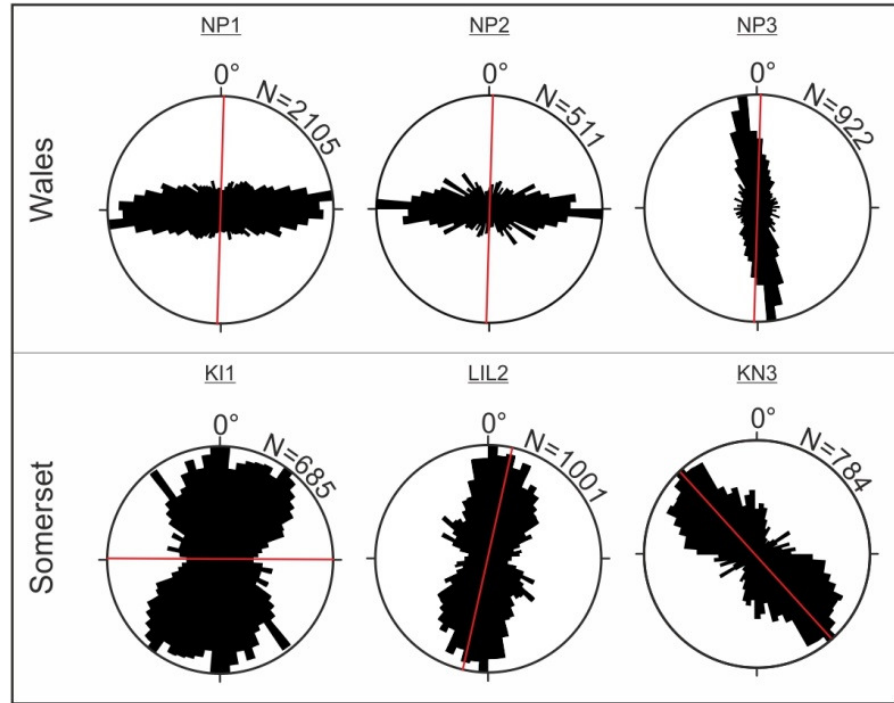

Figure 6.7: Fracture strike of all six sections in symmetrical rose diagrams. In each diagram $\mathrm{N}$ represents the number of each measured fracture segment and the red line the strike of adjacent faults.

fracture sets may be more regularly spaced than non-systematic fracture sets (cf. Gross, 1993; Caputo, 1995).

The Welsh sections are located within a few hundred metres of each other in a tectonically rather uniform area compared with the sections in Somerset. Because of the relatively great distances between the investigated Somerset sections and the complex tectonic history of this area in the East Bristol Channel Basin, the closest faults to the three sections in Somerset were assessed separately.

The faults next to NP1, 2 and 3 strike $\mathrm{N}^{\circ} 70^{\circ}$ and have a throw of 1.9-2.6 m. NP1 is located closest to the next fault plane ( 4 m; Tab. 6.1). The E090 striking fractures of sections NP1 and 2 are perpendicular to the next fault planes, whereas the fractures in NP3 strike N-S, i.e. parallel to the fault (Fig. 6.7, Tab. 6.1). The orientations and displacements of the closest faults as well as their spatial relationship with the investigated sections were documented in detail in the field (cf. Fig. 6.8). 

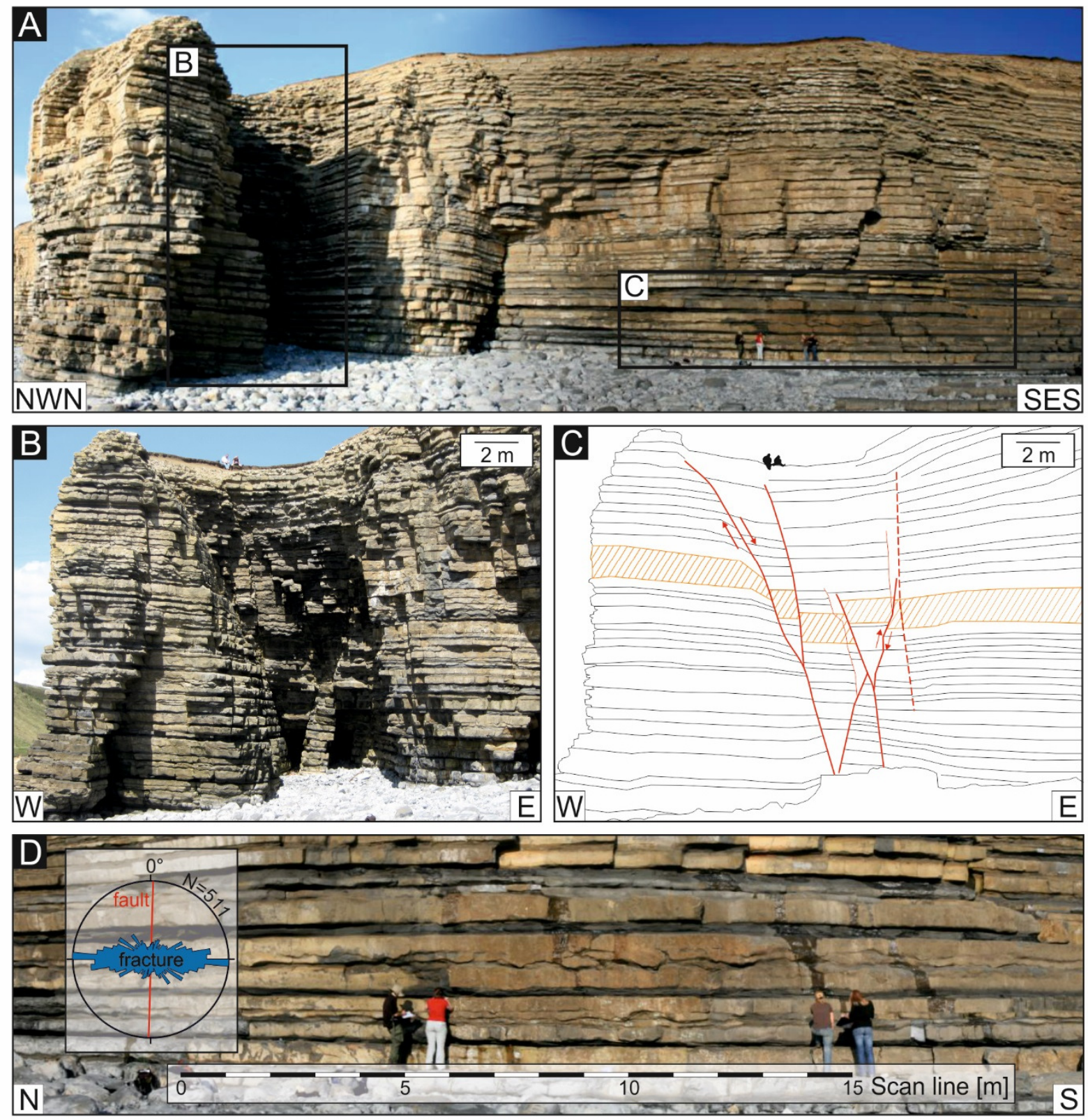

Figure 6.8: Outcrop overview of section NP2. A) Outcrop wall strikes parallel to the strike of the fault plane; B) Photo of the fault (with persons as scale); C) Sketch indicating fault details. At a distinct nodular bed unit (hatched in orange) the fault throw is $1.9 \mathrm{~m}$; D) Selected section (NP2) with a length of $15 \mathrm{~m}$ and a height of $2 \mathrm{~m}$. The strike of the scan-line is always oriented parallel to the outcrop wall. Here the main fracture set strikes perpendicular to the fault orientation (symmetrical rose diagram as inset).

The closest fault to section $\underline{\mathrm{KI}}$ ( $\sim 2 \mathrm{~m}$ distance) is an E090 ${ }^{\circ}$-striking normal fault with a throw of $2 \mathrm{~m}$ (Tab. 6.1); fractures strike from NNW-SSE to NNE-SSW perpendicular to this fault (Fig. 6.7, Tab. 6.1). The closest fault to section LIL2 $(\sim 14.5 \mathrm{~m}$ to the west) is a steep reverse fault with a throw of $0.6 \mathrm{~m}$ (Tab. 6.1); fractures strike $10^{\circ}$ parallel to the fault plane (Fig. 6.7, Tab. 6.1). The fault adjacent to section $\underline{\mathrm{KN} 3}(\sim 7.5 \mathrm{~m}$ to the west) is a reverse (inverted 
normal) fault with a throw of $0.2 \mathrm{~m}$ (Tab. 6.1); the main fracture strike is at $135^{\circ}$, i.e. parallel to the fault (Fig. 6.7, Tab. 6.1).

\section{Fracture density and spacing}

The fracture density of each limestone bed and marl interbed is shown in Figure 6.9A, with different symbols displayed for each section. Whereas the thicknesses of beds and interbeds exhibit clear and considerable dispersion in every section, fracture density dispersion is small in most sections (with the exception of NP1; Fig. 6.9A), indicating distinct differences in fracture densities between individual sections. In contrast to semi-nodular limestones, wellbedded limestones vary significantly with regard to both bed thickness and fracture density (Fig. 6.9B). Indeed, it is remarkable that fracture densities in semi-nodular limestones are generally lower despite the presence of lower bed thicknesses (between 6 and $16.5 \mathrm{~cm}$ ) in which higher fracture densities would rather be expected (Fig. 6.9B). Also noticeable are two well-bedded limestones characterised by fracture densities and bed thicknesses comparable to those of semi-nodular limestones (red circle in Fig. 6.9B). However, this can possibly be explained by the very thick marl interbeds below the respective limestone beds, likely acting as a mechanical buffer. If only well-bedded limestones are considered and the two exceptional well-bedded limestone beds discussed above are excluded, there is good correlation between fracture densities and bed thicknesses (Fig. 6.9C). 


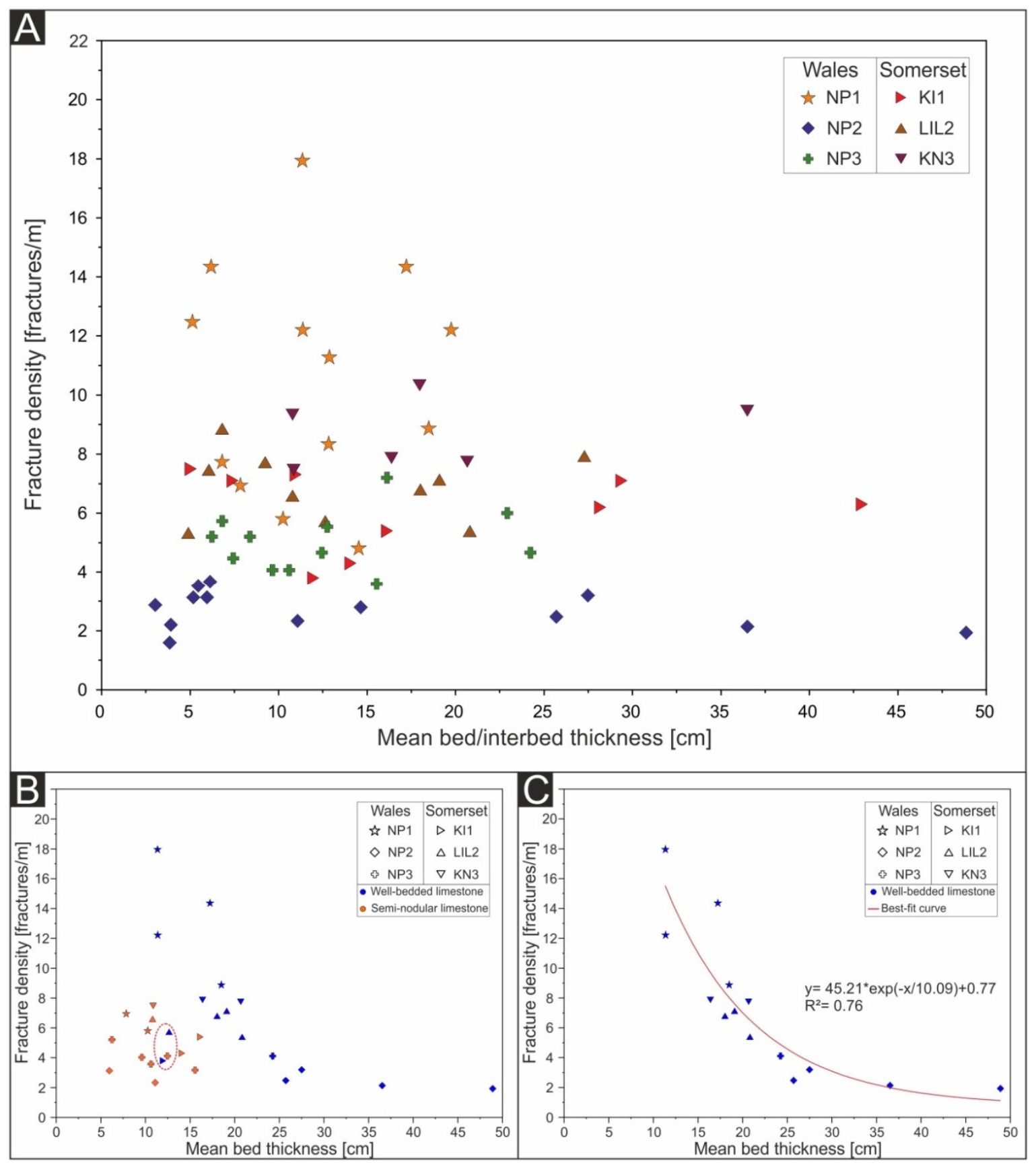

Figure 6.9: A) Fracture density [fractures per metre] vs. mean bed/interbed thickness [cm] in all sections (Number of beds $=63$, Number of fractures $=4010$ ); B) Fracture density [fractures per metre] vs. mean bed thickness [cm] of semi-nodular limestones (orange symbols) and well-bedded limestones (blue symbols) in all sections (Number of beds $=29$, Number of fractures $=2553$ ). Red circle emphasises two limestone beds; C) Fracture density [fractures per metre] vs. mean bed thickness [cm] of well-bedded limestones in all sections (Number of beds $=14$, Number of fractures $=1929$ ). The negative exponential best-fit curve (red line) shows a high coefficient of determination $\left(\mathrm{R}^{2}=0.763\right)$, indicating good correlation between fracture densities and bed thicknesses. 
The coefficient of determination $\left(\mathrm{R}^{2}=0.76\right)$ indicates that $76 \%$ of the recorded dispersion in fracture density can be explained by the dispersion of bed thickness. Median fracture spacing ranges from 9 to $24 \mathrm{~cm}$ and median bed thickness from 7 to $21 \mathrm{~cm}$ (Fig. 6.10). Compared with other empirical studies (e.g. Narr and Suppe, 1991), bed thicknesses and associated fracture spacings are relatively low in the present study. Nevertheless, a slight correlation between median fracture spacing and bed thickness with a coefficient of determination of 0.4 is evident in the data (Fig. 6.10).

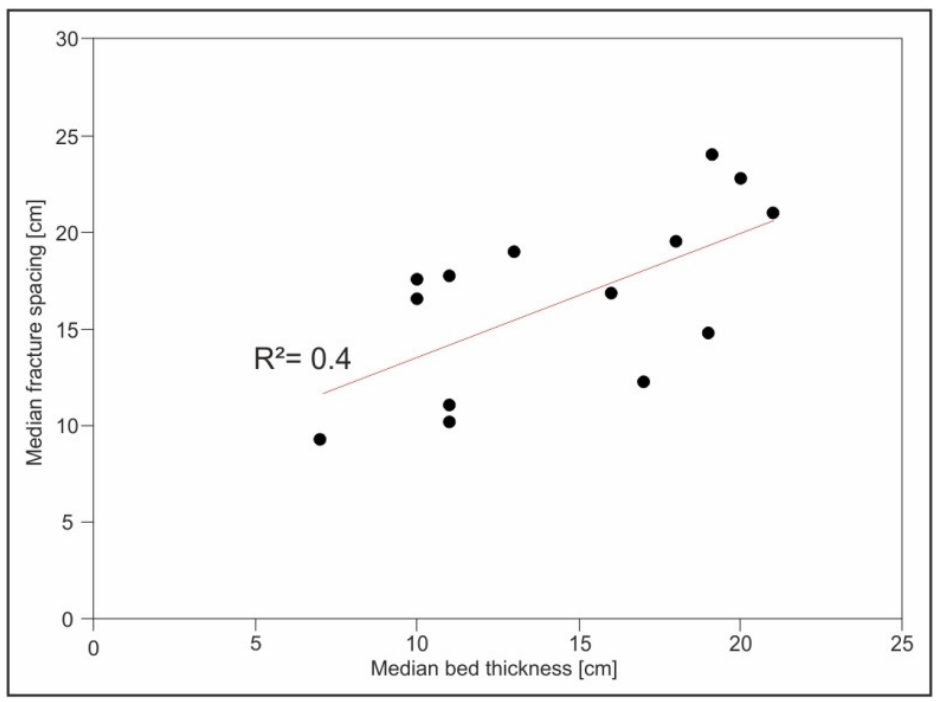

Figure 6.10: Median fracture spacing $[\mathrm{cm}]$ vs. median bed thickness [cm] (Number of beds $=14$, Number of fractures $=999$ ). The positive regression line (red line) shows a low coefficient of determination, indicating a weak correlation between median fracture spacing and median bed thickness.

The whisker diagrams displayed in Figure 6.11 reveal further details regarding the distributions of bed thickness and fracture spacing in individual beds from three selected subsections, containing the three best representative limestone beds, respectively. Whisker diagrams illustrate the differences between populations of numerical data and hence have the advantage of excluding extreme values. As the length of the box in a whisker diagram represents the interquartile range, that is, the range represented by half the data. Figure 6.11 indicates a large degree of dispersion in fracture spacing. Furthermore, the fact that the mean is always larger than the median demonstrates the skewness of the distributions (Fig. 6.11). In some beds both the fracture spacing and bed thickness measured at several points vary significantly (Fig. 6.11). It is noticeable that in such cases there is a coherent dispersion of fracture spacing and bed thickness, e.g. decreasing dispersion in fracture spacing with decreasing dispersion in bed thickness (Fig. 6.11). 

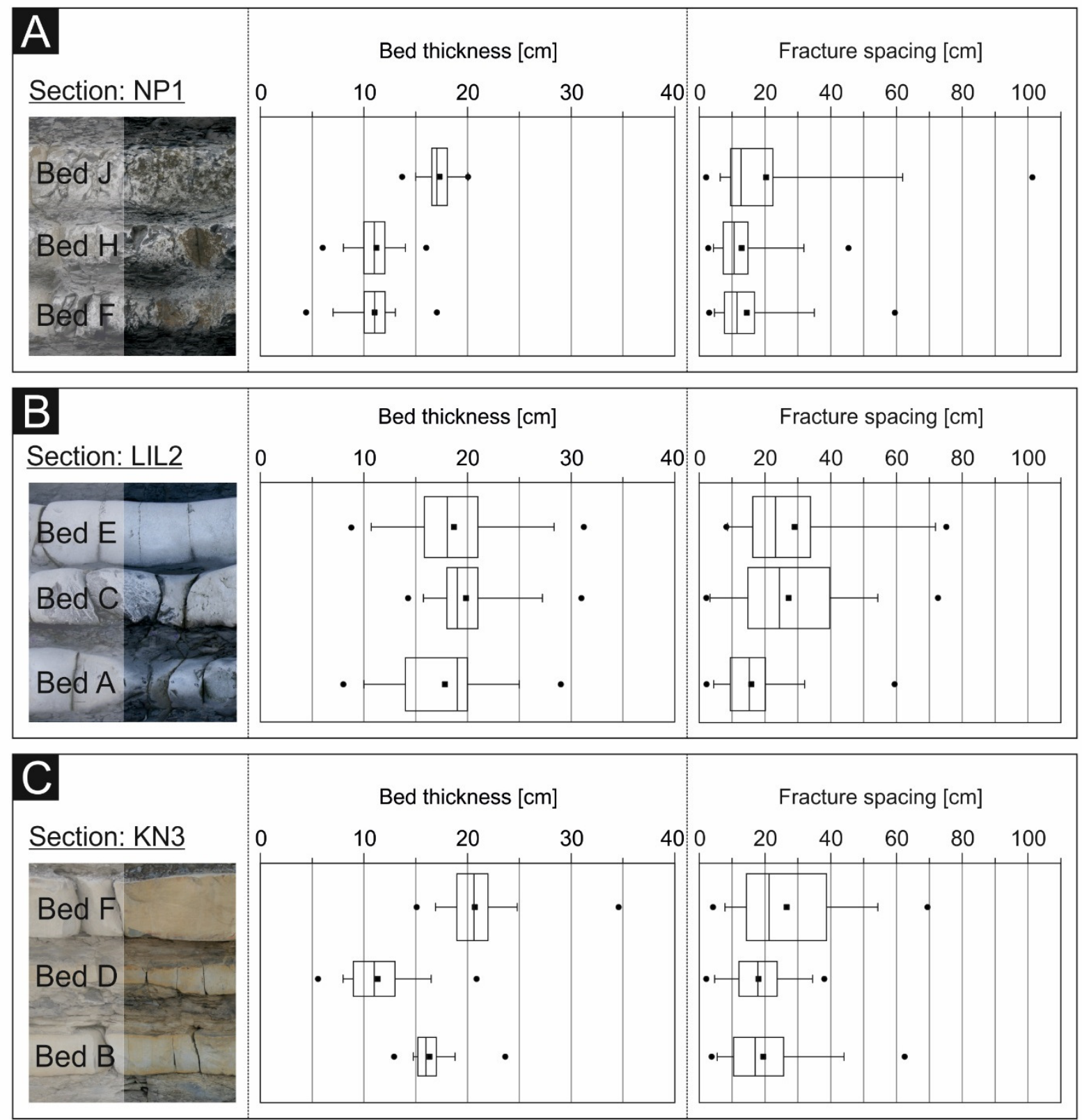

Figure 6.11: Whisker diagrams representing the distribution of fracture spacing $[\mathrm{cm}]$ and bed thickness [cm] of three selected subsections, containing the best representative limestone beds, respectively. A) Subsection NP1; B) Subsection LIL2; C) Subsection KN3 (Statistical outliers are plotted as dots and arithmetic means as squares. The vertical line in each box represents the median and the length of the box the dispersion of the data).

$\underline{\text { Fracture height }}$

Regarding vertical fracture propagation, fracture heights were documented and stratabound and non-stratabound fractures distinguished for well-bedded and semi-nodular limestones, 
respectively (Fig. 6.12). Across

all six sections, the well-bedded limestones contain 1657 fractures distributed in 16 beds, with the semi-nodular limestones containing $\quad 896 \quad$ fractures distributed in 13 beds. Percentages of non-stratabound fractures are different between semi-nodular and well-bedded limestones $(67 \%$ and $43 \%$, respectively; Fig. 6.12).

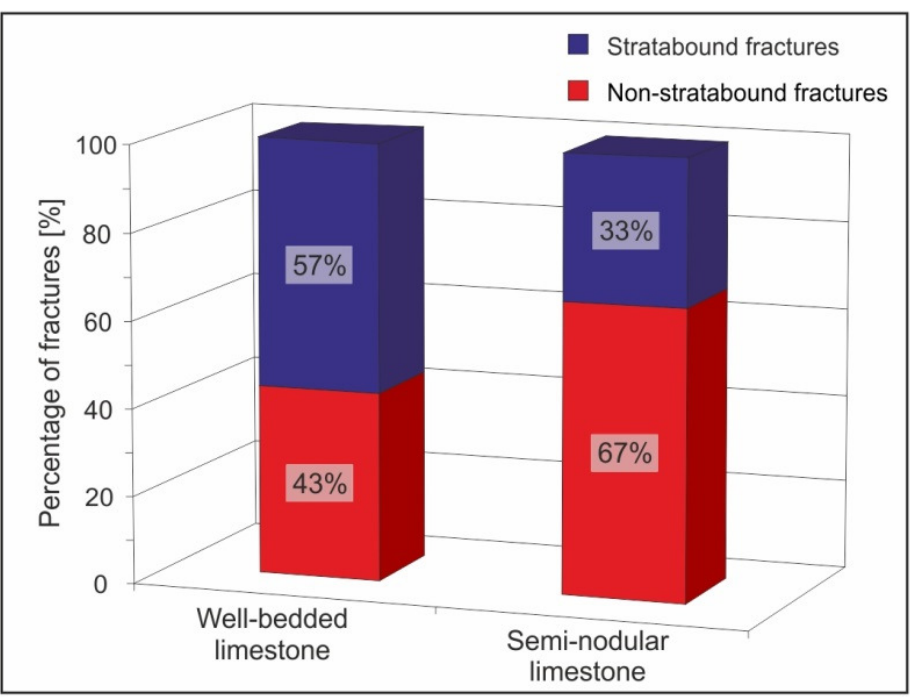

Figure 6.12: Percentages of fractures from all six sections, distinguishing non-stratabound fractures [\%] in red and stratabound fractures [\%] in blue bars, separated in well-bedded (Number of fractures $=1657$, Number of

\subsection{Discussion} beds $=16$ ) and in semi-nodular limestone beds (Number of fractures $=896$, Number of beds $=13$ ).

\subsubsection{Fracture distribution in layered rocks}

\section{Fracture relation to faults}

Previous studies have shown that fracture density depends on lithology (composition and grain size; e.g. Aguilera, 1995), distance to faults (Vermilye and Scholz, 1999), and fault zone architecture (Caine et al., 1996). In general, fracture density increases on approaching the fault core, which itself strongly depends on the thickness of the fault-damage zone (Caine et al., 1996). The thickness of a damage zone is in turn influenced by a range of parameters including the fault displacement or throw (Faulkner et al., 2010). Therefore we selected sections in which the distance to the fault plane is large enough to ensure unfaulted rocks. There are, however, differences in fracture densities between individual sections (Fig. 6.9A), this may be explained by an increase in fracture densities associated with the distance to adjacent faults.

Whereas the orientations of the fracture sets in NP1, 2 and 3 are characterised by a clear main strike direction, the orientations of the Somerset fracture sets vary significantly (Fig. 6.7) due to various different tectonic events which took place on the southern and northern margins of the BCB. The fractures in NP1, 2 and 3 belong to orthogonal fracture sets, with the E-W- 
striking fractures in $\underline{\mathrm{NP} 1}$ and 2 representing the non-systematic fracture set and those in $\underline{\mathrm{NP}} 3$ consequently the systematic fracture set strike $\left(\mathrm{N} 155-160^{\circ}\right)$. The systematic fracture set is parallel to and thus probably associated with the conjugated strike-slip faults (red line; Fig. 6.7; cf. Petit et al., 1999).

Within a large scatter fractures strike in section KI1 from NNW-SSE to NNE-SSW, exhibiting three main fracture sets with NNW-SSE, N-S and NNE-SSW-strike (Fig. 6.7). The fracture NNW-SSE and NNE-SSW sets exhibit the same orientations as the conjugated strikeslip faults documented by Bowyer and Kelly (1995). The sinistral fault has a mean strike of $38^{\circ}$ and the dextral fault a mean strike of $315-05^{\circ}$ (Peacock and Sanderson, 1992; Bowyer and Kelly; 1995). The fractures belonging to these two fracture sets are less planar in appearance. The fault adjacent to $\underline{\mathrm{KI}}$ belongs to a series of E-W-striking normal faults and related veins, many showing reverse reactivation (Bowyer and Kelly, 1995). The N-S-striking fractures of LIL2 are parallel to the adjacent fault and represent the systematic fracture set of the respective fault block. The fractures in $\underline{\mathrm{KN} 3}$ strike $135^{\circ}$, parallel to the NW-SE-striking reverse (inverted normal) fault and represent the systematic fracture set. The area of Somerset, however, is separated into distinct fault blocks characterised by differences in both fault strike and fracture patterns (cf. Bowyer and Kelly, 1995).

Fracture density and spacing associated with variation in bed thicknesses and irregularities of bedding planes

Semi-nodular limestones, that is, beds with bedding plane irregularities, exhibit significantly lower fracture densities despite their low bed thicknesses (Fig. 6.9B). This cannot be explained by the sampling of solely semi-nodular limestone beds in only one section, since semi-nodular limestones are present in all sections. Beds in NP1 are generally characterised by relatively high fracture densities. However, two of the beds are semi-nodular limestones which exhibit lower fracture densities than the well-bedded limestones of NP1 (Fig. 6.9B; orange stars). Thus, fracture density depends not only on bed thickness but also on irregularities of bedding planes.

In our data a coherence of the dispersion in bed thicknesses and fracture spacing is apparent. Whereas fractures in beds with low dispersion in thicknesses are more regular spaced, fractures in beds with high dispersion in bed thicknesses are more irregular spaced. A similarly high dispersion in joint spacing was observed by Narr (1991) who considered the 
variation in layer thicknesses as negligible. The standard deviation in joint spacing is about 0.5 times the median joint spacing (Narr, 1991). In the following, the validity of different parameters (e.g. $S / T_{f}, C_{v}, X_{\text {mean }}, X_{\text {median }}, \sigma$ ) describing fracture spacing and which are generally used in the literature will be evaluated based on our data (Fig. 6.11). Possible explanations for the observed coherence of dispersion in bed thickness and fracture spacing will also be discussed.

The wide dispersion of fracture spacing within an individual limestone bed can be explained using the concept of fracture saturation (Bai and Pollard, 2000). When fracture saturation is reached, the spacing depends only on bed thickness and thus should be relatively regular. In contrast, fracture spacing is probably more irregular when fracture saturation is not reached. Based on a three-layer elastic model (FEM) with a fractured central layer, Bai and Pollard (2000) defined a fracture spacing to layer thickness ratio $\left(\left(\mathrm{S} / \mathrm{T}_{\mathrm{f}}\right)_{\mathrm{cr}}\right)$ of 1.2 as the critical threshold for the identification of fracture saturation in beds; thus, if $\mathrm{S} / \mathrm{T}_{\mathrm{f}}$ is higher than 1.2, fracture saturation is not reached (Bai and Pollard, 2000). The $S / T_{f}$ ratios of all beds from three sections (NP1, LIL2, KN3) vary from 0.72 to 1.76 , with the central bed C in LIL2, for example, exhibiting an $\mathrm{S} / \mathrm{T}_{\mathrm{f}}$ ratio of 1.26 (Tab. 6.3). Based on Bai and Pollard (2000) this bed would not be defined as fracture saturated, which is in good accordance with the large dispersion of fracture spacing $(15 \mathrm{~cm}$ to $40 \mathrm{~cm}$; i.e. fractures in this bed are more irregular spaced) and the smaller dispersion of bed thicknesses in this bed (Fig. 6.11). In contrast, beds A and E in this section are, based on Bai and Pollard (2000), fracture saturated, but both exhibit a large dispersion of fracture spacing, thus fractures in these beds are more irregular spaced as well, compared to beds F,H,J of NP1. This demonstrates that the concept of fracture saturation may not be applicable to beds with variable bed thicknesses.

Another parameter with which to describe the spatial heterogeneity of fracture spacing is the coefficient of variation $\left(\mathrm{C}_{\mathrm{v}}\right)$, defined as the standard deviation divided by the arithmetic mean (e.g. Putz-Perrier and Sanderson, 2008). If fractures are regularly spaced $C_{v}<1$, whereas for $\mathrm{C}_{\mathrm{v}}>1$ the fractures are clustered (e.g. Putz-Perrier and Sanderson, 2008). For the investigated beds, $\mathrm{C}_{\mathrm{v}}$ ranges from 0.47 to 1.23 (Tab. 6.3), indicating regular spacing. However, fracture spacing varies significantly in the beds of LIL2 (Fig. 6.11). These discrepancies may be explained by the fact that the arithmetic mean $\left(\mathrm{X}_{\text {mean }}\right.$; Tab. 6.3) used in the calculation of $\mathrm{C}_{\mathrm{v}}$ is not applicable to skewed distributions or for data revealing extreme outliers (Spiegel and Stephens, 1999), as is the case for the observed fracture spacing (Fig. 6.11); for such data the median is a better and more stable estimator (Narr and Suppe, 1991). However, for bed J in 
section NP1 and beds $\mathrm{C}$ and $\mathrm{E}$ in section LIL 2, the median is still not representative (Fig. 6.11). Therefore to evaluate the distribution of fracture spacing we suggest using whisker diagrams.

\begin{tabular}{|c|c|c|c|c|c|c|c|c|}
\hline Section & Bed & Lithology & $S / T_{f}$ & $\mathrm{C}_{\mathrm{v}}$ & $X_{\text {mean }}$ & $X_{\text {median }}$ & $\sigma$ & $\mathrm{N}$ \\
\hline \multirow{6}{*}{ NP1 } & $\mathrm{L}$ & SNL & 1.33 & 0.81 & 11.98 & 9.30 & 9.69 & 78 \\
\hline & $\mathrm{J}$ & WBL & 0.72 & 0.94 & 19.95 & 12.27 & 18.75 & 76 \\
\hline & $\mathrm{H}$ & WBL & 0.93 & 0.81 & 12.48 & 10.2 & 10.17 & 136 \\
\hline & $\mathrm{F}$ & WBL & 1.01 & 0.75 & 14.02 & 11.07 & 10.45 & 126 \\
\hline & $D$ & WBL & 1.09 & 1.23 & 28.32 & 19.53 & 34.84 & 57 \\
\hline & $B$ & SNL & 1.66 & 1.15 & 26.79 & 16.56 & 30.74 & 63 \\
\hline \multirow{5}{*}{ LIL2 } & $\mathrm{J}$ & SNL & 1.76 & 0.76 & 23.90 & 17.57 & 18.14 & 46 \\
\hline & $\mathrm{H}$ & WBL & 1.46 & 0.67 & 23.34 & 19 & 15.61 & 49 \\
\hline & $E$ & WBL & 1.14 & 0.61 & 28.61 & 22.79 & 17.47 & 51 \\
\hline & C & WBL & 1.26 & 0.63 & 26.84 & 24.02 & 16.82 & 49 \\
\hline & $A$ & WBL & 0.78 & 0.58 & 15.44 & 14.8 & 8.95 & 73 \\
\hline \multirow{3}{*}{ KN3 } & $F$ & WBL & 1 & 0.58 & 26.05 & 21.01 & 15.12 & 59 \\
\hline & $D$ & SNL & 1.61 & 0.47 & 17.97 & 17.75 & 8.36 & 77 \\
\hline & B & WBL & 1.05 & 0.62 & 19.02 & 16.86 & 11.86 & 59 \\
\hline
\end{tabular}

Table 6.3: The table lists selected fracture parameters of three sections NP1, LIL2, KN3 (S/ $\mathrm{T}_{\mathrm{f}}$ $=$ fracture spacing to bed thickness ratio, $\mathrm{C}_{\mathrm{V}}=$ coefficient of variation of the fracture spacing, $\mathrm{X}_{\text {mean }}=$ arithmetic mean of fracture spacing, $X_{\text {median }}=$ median of fracture spacing, $\sigma=$ standard deviation of fracture spacing).

In conclusion, the significant dispersions in fracture spacing do not show any correlation with fracture saturation, but rather with variable bed thicknesses (in scale of $15 \mathrm{~m}$ long beds; cf. Fig. 6.11).

\section{Vertical fracture propagation in stiff beds}

Percentages of non-stratabound fractures are lower in well-bedded than semi-nodular limestones (Fig. 6.12). It has long been recognised that fracture spacing and height are strongly affected by mechanical layering (e.g. Gudmundsson and Brenner, 2001; Odonne et al., 2007; Larsen et al., 2010; Philipp et al., 2013; see chapter 9 for details). 


\begin{tabular}{|c|c|c|}
\hline & $\begin{array}{c}\text { Well-bedded } \\
\text { limestone }\end{array}$ & $\begin{array}{c}\text { Semi-nodular } \\
\text { limestone }\end{array}$ \\
\hline \hline $\mathrm{CaCO}_{3}[\mathrm{wt} \%]$ & $50-89$ & $66-92$ \\
\hline $\mathrm{C}_{\text {org }}[\mathrm{wt} \%]$ & $0.22-0.54$ & $0.18-0.51$ \\
\hline Effective porosity [\%] & 0.82 & 1.52 \\
\hline Rock hardness [RE] & $537-630$ & $483-634$ \\
\hline UCS calc. [MPa] & $170-262$ & $129-265$ \\
\hline Tensile strength [MPa] & 11 & 9 \\
\hline Young's modulus [GPa] & 48 & 38 \\
\hline UCS [MPa] & 170 & 165 \\
\hline
\end{tabular}

Table 6.4: $\mathrm{CaCO}_{3}-/ \mathrm{C}_{\text {org }}$ content and rock mechanical properties of well-bedded and semi-nodular limestones. There is no remarkable difference between these two limestone lithologies.

However, there are no remarkable differences in the rock mechanical properties (e.g. effective porosity, rock hardness, tensile strength, Young's modulus and UCS) of the studied well-bedded and semi-nodular limestones (Tab. 6.4), nor are the observed bedding plane irregularities related to variation in $\mathrm{CaCO}_{3}$ or $\mathrm{C}_{\text {org }}$ content (Fig. 6.13, Tab. 6.4). When considering all lithologies, however, the percentages of non-stratabound fractures roughly increase with increasing $\mathrm{CaCO}_{3}$ content [wt \%]. The calculated coefficient of determination $\left(\mathrm{R}^{2}=0.41\right)$ indicates that $41 \%$ of the dispersion of non-stratabound fractures can be explained by variations in $\mathrm{CaCO}_{3}$ content (Fig. 6.13).

The varying amounts of non-stratabound fractures in the different limestone lithologies cannot be explained by the biased sampling of certain sections, because each section comprises at least one semi-nodular limestone bed containing a higher percentage of nonstratabound than stratabound fractures. Nor can the variation be explained as the result of investigating only the systematic fracture set, in which higher percentages of non-stratabound fractures are typical. We examined the non-systematic fracture set in sections NP1, 2 and KI1, with all three characterised by remarkably high percentages of non-stratabound fractures in their semi-nodular limestone beds.

One possible mechanical explanation for the different fracture distributions observed in the well-bedded and semi-nodular limestones could be that fracturing interfacial shear stress was inherent based on the contrasting mechanical properties of the limestone beds and marl interbeds (cf. Mandl, 2005). The interface between different lithologies is commonly a weakness plane (a discontinuity) with reduced cohesion and coefficient of sliding friction (Peacock and Sanderson, 1992). Renshaw and Pollard (1994) propose that when slip at weakness planes occurs, stresses cannot be transmitted across the interface and thus fractures become arrested. In cases of planar weakness planes (i.e. well-bedded limestones), fracture spacing is more regular and depends on bed thickness. If weakness planes are more irregular 
(i.e. semi-nodular limestones), however, the slip of a weakness plane may be disabled, stresses can be better transmitted across interfaces and thus fractures can propagate through more than one layer. In addition, the thinner parts of the semi-nodular limestones are likely zones of stress concentration (cf. Gudmundsson, 2011), leading to higher probabilities of fracture initiation or propagation. Consequently, fracture propagation in semi-nodular limestones is directly linked to bedding plane irregularities.

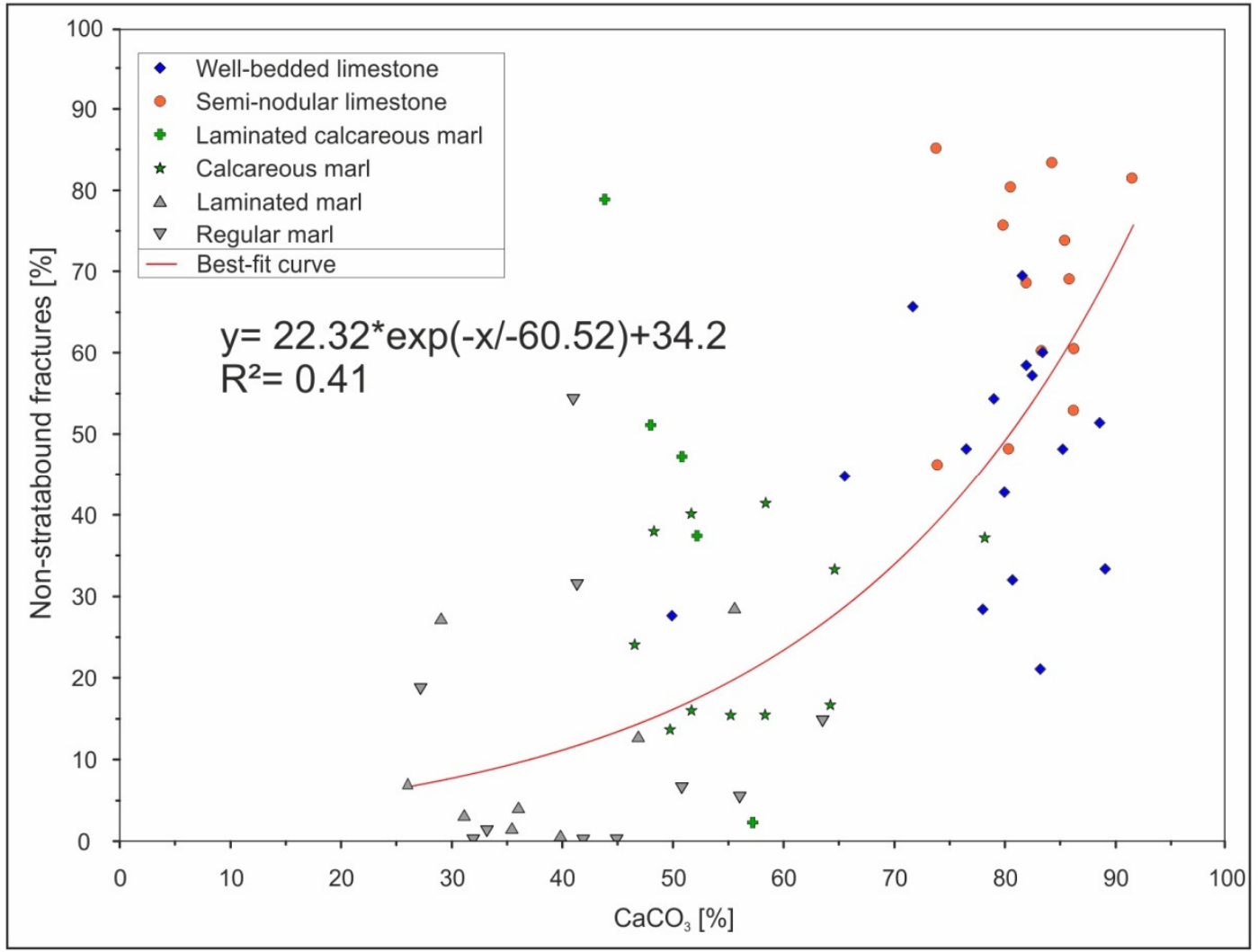

Figure 6.13: Non-stratabound fractures [\%] vs. $\mathrm{CaCO}_{3}$ [wt \%] (Number of beds $=63$, Number of fractures $=4010$ ); Lithologies are illustrated in different colours. Percentages of non-stratabound fractures roughly increase with increasing $\mathrm{CaCO}_{3}$ content. The positive exponential best-fit curve (red line) shows the coefficient of determination $\left(\mathrm{R}^{2}=0.41\right)$, indicating weak correlation between non-stratabound fractures [\%] and $\mathrm{CaCO}_{3}[\mathrm{wt} \%]$.

\subsubsection{Effects of bedding plane irregularities on fracture propagation}

Since the fracture distribution differs considerably between the well-bedded and semi-nodular limestones, we next discuss the origin of the bedding plane irregularities. One of the general explanations for nodular limestones is the fossil content, with less fossiliferous limestones tending to have planar bedding surfaces (e.g. Hallam, 1960; Flügel, 2010). However, in the Blue Lias Formation there is no linkage between nodular limestones and the occurrence of 
microfossils (Hallam, 1960). The bedding plane irregularities in the Welsh Blue Lias Formation do not represent the original configurations on the sea bottom (Hallam, 1960). Omission surfaces documented by Sheppard et al. (2006) indicate an absence of sedimentation. Generally, many of these omission surfaces exhibit irregular protuberances (Flügel, 2010) which may account for the bedding plane irregularities in the Blue Lias Formation. Wobber (1967), however, explained such irregularities as being post-depositional and diagenetic in origin.

In order to investigate the impact of diagenesis on fracture propagation in diagenetically overprinted successions, we chose sections NP1-NP3 in Wales as representative examples. The bedding plane irregularities in all three subsections are caused by different sedimentological and diagenetic processes (Fig. 6.6). The first subsection (NP1) comprises relatively planar surfaces and undeformed bioturbation, indicative of a very early lithification state (Fig. 6.6A) characterised by low percentages of non-stratabound fractures in limestone beds and marl interbeds (Fig. 6.14B). The second subsection (NP2) reveals evidence for differential compaction, a phenomenon also observed in several LMA and explained by the dissolution and cementation processes of carbonates during early diagenesis (e.g. Ricken, 1986; Westphal et al., 2000; Munnecke and Westphal, 2005). This subsection contains notably high percentages of non-stratabound fractures in well-bedded limestone and seminodular limestone beds, as well as in marl interbeds (Fig. 6.14B).

The third subsection (NP3) is predominantly characterised by semi-nodular limestone beds (Fig. 6.6C). It seems likely that trace fossils caused initial irregularities that were subsequently amplified by increasing overburden pressure during the early post-depositional stage. This is in good accordance with Wobber (1967), who proposed sediment load, overburden pressure, interstratal sliding due to local subsidence, as well as local but multidirectional compaction stresses as crucial diagenetic processes. This subsection also contains high percentages of non-stratabound fractures in the well-bedded and semi-nodular limestone beds, but only low percentages in the marl interbeds (Fig. 6.14B).

\subsection{Implications for reservoir permeability and exploration}

The overall characteristics of beds, being the product of both sedimentary and diagenetic processes, significantly affect the fracture distribution in layered rocks. Although this 
probably applies to all types of sedimentary alternations (e.g. limestone-marl, sandstone-shale), for most types of such successions, studies have as yet not been carried out. Whereas the thin, well-bedded limestones show high fracture densities, the semi-nodular limestones (with the same bed thicknesses as the well-bedded limestones) exhibit lower fracture densities (Fig. 6.9B). Furthermore, there is coherence between the dispersion of fracture spacing and bed thickness (Fig. 6.11). This means beds with variable bed thicknesses are characterised by different fracture spacing (Fig. 6.11). In addition, these semi-nodular limestones exhibit significantly higher percentages of non-stratabound fractures than the wellbedded limestones (Fig. 6.12). Here we have shown that the fracture distribution varies significantly in the strata investigated; consequently, planar bedding planes (well-bedded limestones) and beds with bedding plane irregularities (semi-nodular limestones) must be distinguished.

Since processes leading to bedding plane irregularities in the Blue Lias Formation differ even on small scales (cf. subsections 6.5.1. and 6.6.2.), outcrop analogue studies appear problematic. Despite their close proximity to one another $(<500 \mathrm{~m})$, the three sections NP1-NP3 exhibit different sedimentological and diagenetic features and are characterised by dissimilar percentages of stratabound and non-stratabound fractures (Fig. 6.14). In cases of differential compaction (section NP2) for example, cementation and dissolution processes affect neither the rock mechanical properties (i.e. rock hardness, effective porosity) nor the $\mathrm{CaCO}_{3}$ content of the semi-nodular limestones and well-bedded limestones directly, but rather those of the adjacent marl interbeds. Together these layers can be seen as mechanical unit consisting of multiple layers and beds, in which the number of non-stratabound fractures is higher than in NP1 (Fig. 6.14). This underlines the general difficulty of extrapolating outcrop data to the subsurface, which is particularly problematic in the case of LMA strongly affected by diagenetic processes. Such studies thus show that it is also more difficult to find the smallest volume which could represent the whole (REV; Representative Elementary Volume) for this kind of rock. For successful exploration, the effects of all of these processes on fracture distribution in layered reservoirs needs to be understood. 

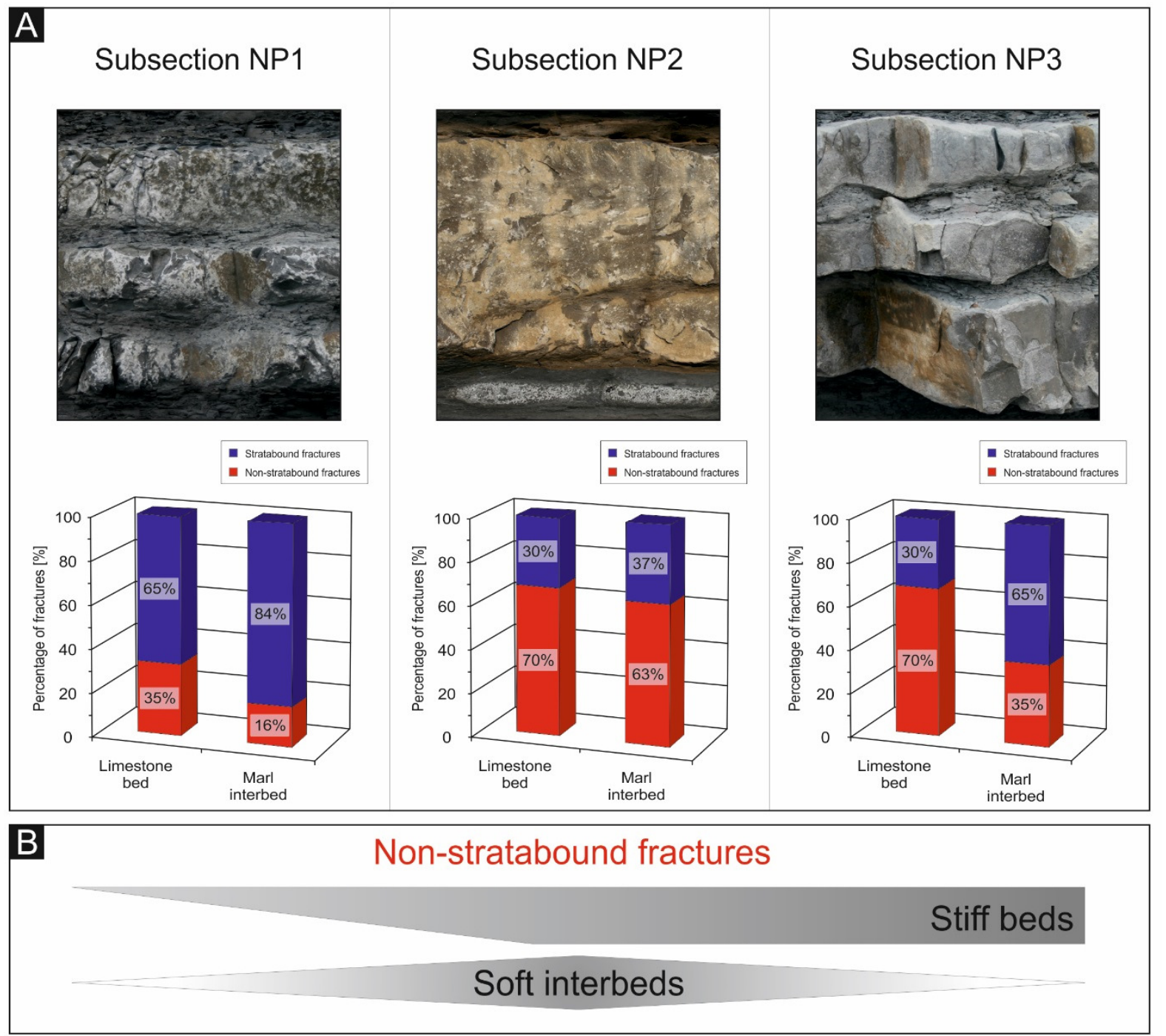

Figure 6.14: A) Percentages of non-stratabound fractures [\%] in red and stratabound fractures [\%] in blue bars, separately for limestone beds and marl interbeds of three selected subsections with different sedimentological and diagenetic features; B) Percentages of nonstratabound fractures [\%] summarised for the three selected subsections, which are all characterised by dissimilar percentages of non-stratabound fractures in stiff beds and soft interbeds.

\section{Acknowledgments}

This study was supported by the Deutsche Forschungsgemeinschaft (DFG, grant PH 189/2-1). Sebastian Flotow (Leibniz Centre for Tropical Marine Ecology) prepared the thin sections, and Dr Andreas Reimer and Birgit Röring (Georg-August University of Göttingen) helped with the CNS analyses. We thank the research group of Prof. Joachim Reitner and the tectonics laboratory group of Prof. Siegfried Siegesmund (all of Georg-August University of Göttingen) for providing support. Dr Jan-Peter Duda and Jonathan Lavi are acknowledged for 
their assistance in the field, with the former also acknowledged for constructive discussions and proof reading. Critical comments by Prof. Agust Gudmundsson, two anonymous reviewers and the editor Dr Nereo Preto helped improve the manuscript.

\section{References}

Aguilera R. (1995) Naturally Fractured Reservoirs. Second ed., PennWell Publishing Company, Tulsa, Oklahoma.

Aguilera R. (2000) Well test analysis of multi-layered naturally fractured reservoirs. Journal of Canadian Petroleum Technology, 39, 31-37.

Bai T., Maerten L., Gross M.R., Aydin A. (2002) Orthogonal cross joints: do they imply a regional stress rotation? Journal of Structural Geology, 24, 77-88.

Bai T., Pollard D.D. (2000) Fracture spacing in layered rocks: a new explanation based on the stress transition. Journal of Structural Geology, 22, 43-57.

Belayneh M., Cosgrove J.W. (2010) Hybrid veins from the southern margin of the Bristol Channel Basin, UK. Journal of Structural Geology, 32, 192-201.

Bell F.G. (2000) Engineering properties of soils and rocks. Fourth ed., Blackwell, Oxford.

Bogdanov A.A. (1947) The intensity of cleavage as related to the thickness of beds. Soviet Geology, 16, 102-104 (cited by Ortega et al., 2006).

Boro H., Bertotti G., Hardebol N.J. (2013) Distributed fracturing affecting isolated carbonate platforms, the Latemar platform natural laboratory (Dolomites, North Italy). Marine and Petroleum Geology, 40, 69-84.

Bowyer M.O., Kelly P.G. (1995) Strain and scaling relationships of faults and veins at Kilve. Proceedings of the Ussher Society, 8, 411-415.

Caine J.S., Evans J.P., Forster C.B. (1996) Fault zone architecture and permeability structure. Geology, 24, 1025-1028.

Caputo R. (1995) Evolution of orthogonal sets of coeval extension joints. Terra Nova, 7, 479-490.

Cope J.C.W. (2006) Jurassic: the returning seas. In: Brenchley P.J., Rawson P.F. (Eds.) The Geology of England and Wales. Second ed., Journal of the Geological Society London, pp. 325-363.

Dart C.J., McClay K., Hollings P.N. (1995) 3D analysis of inverted extensional fault systems, southern Bristol Channel Basin, UK. In: Buchanan J.G., Buchanan P.G. (Eds.) Basin Inversion. Geological Society London Special Publications London, pp. 393-413.

Dunham R.J. (1962) Classification of carbonate rocks according to depositional texture. In: Ham W. E. (Eds.) Classification of Carbonate Rocks. American Association of Petroleum Geologists Memoir, pp. 108-121.

Faulkner D.R., Jackson C.A.L., Lunn R.J., Schlische R.W., Shipton Z.K., Wibberley C.A.J., Withjack M.O. (2010) A review of recent developments concerning the structure, mechanics and fluid flow properties of fault zones. Journal of Structural Geology, 32, 1557-1575.

Flügel E. (2010) Microfacies of Carbonate Rocks Analysis, Interpretation and Application. Second ed., with a contribution by Axel Munnecke. Springer, Heidelberg.

Gross M.R. (1993) The origin and spacing of cross joints: Examples from the Monterey Formation, Santa-Barbara Coastline, California. Journal of Structural Geology, 15, 737-751.

Gudmundsson A. (2011) Rock Fractures in Geological Processes. Cambridge University Press, Cambridge.

Gudmundsson A., Brenner S.L. (2001) How hydrofractures become arrested. Terra Nova, 13, 456462.

Gudmundsson A., Kusumoto S., Simmenes T.H., Philipp S.L., Larsen B., Lotveit I.F. (2012) Effects of overpressure variations on fracture apertures and fluid transport. Tectonophysics, 581, 220230.

Hallam A. (1960) A sedimentary and faunal study of the Blue Lias of Dorset and Glamorgan. Philosophical Transactions of the Royal Society B, 243, 1-44. 
Hancock P.L. (1985) Brittle microtectonics: principles and practice. Journal of Structural Geology, 7, 437-457.

Harvey T., Gray J. (2011) The Unconventional Hydrocarbon Resources of Britain's Onshore Basins Shale Gas. London, UK: Department of Energy and Climate Change.

Helgeson D.E., Aydin A. (1991) Characteristics of joint propagation across layer interfaces in sedimentary rocks. Journal of Structural Geology, 13, 897-911.

Hobbs D.W. (1967) The formation of tension joints in sedimentary rocks: An Explanation. Geological Magazine, 104, 550-556.

Hodgson R.A. (1961) Regional study of jointing in Comb Ridge-Navajo Mountain Area Arizona and Utah. American Association of Petroleum Geologists Bulletin, 45, 1-38.

Hoffmann S. (2006) Naturwerksteine Thailands: Lagerstättenerkundung und Bewertung. PhD Thesis, Georg-August-Universität Göttingen, Göttingen.

Kamerling P. (1979) The geology and hydrocarbon habitat of the Bristol Channel Basin. Journal of Petroleum Geology, 2, 75-93.

Ladeira F.L., Price N.J. (1981) Relationship between fracture spacing and bed thickness. Journal of Structural Geology, 3, 179-183.

Larsen B., Gudmundsson A., Grunnaleite I., Sælen G., Talbot M.R., Buckley S.J. (2010) Effects of sedimentary interfaces on fracture pattern, linkage, and cluster formation in peritidal carbonate rocks. Marine and Petroleum Geology, 27, 1531-1550.

Laubach S.E., Olson J.E., Gross M.R. (2009) Mechanical and fracture stratigraphy. American Association of Petroleum Geologists Bulletin, 93, 1413-1426.

Mandal N., Deb S.K., Khan D. (1994) Evidence for a non-linear relationship between fracture spacing and layer thickness. Journal of Structural Geology, 16, 1275-1281.

Mandl G. (2005) Rock joints: The mechanical genesis. Springer, Berlin.

Mastella L. (1972) Interdependence of joint density and thickness of layers in the Podhale Flysch. Bulletin de l'Académie Polonaise des Sciences, 20, 187-196.

Meulenkamp F., Alvarez Grima M. (1999) Application of neural networks for the prediction of the unconfined compressive strength (UCS) from equotip hardness. International Journal of Rock Mechanics and Mining Science, 36, 29-39.

Munnecke A., Westphal H. (2005) Variations in primary aragonite, calcite, and clay in fine-grained calcareous rhythmites of Cambrian to Jurassic age - an environmental archive? Facies, 51, 592-607.

Narr W. (1991) Fracture density in the deep subsurface: Techniques with application to Point Arguello Oil Field. American Association of Petroleum Geologists Bulletin, 75, 1300-1323.

Narr W., Suppe J. (1991) Joint spacing in sedimentary rocks. Journal of Structural Geology, 13, 1037 1048.

Nelson R.A. (1985) Geologic Analysis of Naturally Fractured Reservoirs. First ed., Gulf Publishing Company, Houston, Texas.

Nemčok M., Gayer R., Miliorizos M. (1995) Structural analysis of the inverted Bristol Channel Basin: Implications for the geometry and timing of fracture porosity. In: Buchanan J.G., Buchanan P.G. (Eds.) Basin Inversion. Geological Society London Special Publications London, pp. 355-392.

Norris D.K. (1966) The about mesoscopic fabric of rock masses about some Canadian coal mines. First ISRM Congress, International Society for Rock Mechanics, 1, 191-198.

Odling N.E., Gillespie P., Bourgine B., Castaing C., Chilés J.-P., Christensen N.P., Fillion E., Genter A., Olsen C., Thrane L., Trice R., Aarseth E., Walsh J.J., Watterson J. (1999) Variations in fracture system geometry and their implications for fluid flow in fractured hydrocarbon reservoirs. Petroleum Geoscience, 5, 373-384.

Odonne F., Lézin C., Massonnat G., Escadeillas G. (2007) The relationship between joint aperture, spacing distribution, vertical dimension and carbonate stratification: An example from the Kimmeridgian limestones of Pointe-du-Chay (France). Journal of Structural Geology, 29, 746-758. 
Pascal C., Angelier J., Cacas M.-C., Hancock P.L. (1997) Distribution of joints: Probabilistic modelling and case study near Cardiff (Wales, UK). Journal of Structural Geology, 19, 12731284.

Peacock D.C.P., Sanderson D.J. (1992) Effects of layering and anisotropy on fault geometry. Journal of the Geological Society of London, 149, 793-802.

Petit J.-P., Auzias V., Rawnsley K., Rives T. (1999) Development of joint sets in the vicinity of faults. In: Lehner F.K., Urai J.L. (Eds.) Aspects of Tectonic Faulting. Springer-Verlag, Berlin Heidelberg, pp. 167-183.

Philipp S.L., Afşar F., Gudmundsson A. (2013) Effects of mechanical layering on hydrofracture emplacement and fluid transport in reservoirs. Frontiers in Earth Science, 1, 1-19.

Price N.J. (1966) Fault and Joint Development in Brittle and Semi-Brittle Rock. Pergamon Press, London.

Putz-Perrier M.W., Sanderson D.J. (2008) Spatial distribution of brittle strain in layered sequences. Journal of Structural Geology, 30, 50-64.

Rawnsley K.D., Peacock D.C.P., Rives T., Petit J.-P. (1998) Joints in the Mesozoic sediments around the Bristol Channel Basin. Journal of Structural Geology, 20, 1641-1661.

Reber J.E., Schmalholz S.M., Burg J.-P. (2010) Stress orientation and fracturing during threedimensional buckling: Numerical simulation and application to chocolate-tablet structures in folded turbidites, SW Portugal. Tectonophysics, 493, 187-195.

Renshaw C.E., Pollard D.D. (1994) Numerical simulation of fracture set formation: A fracture mechanics model consistent with experimental observations. Journal of Geophysical Research, 99, 9359-9372.

Ricken W. (1986) Diagenetic bedding: A model for marl-limestone alternations. In: Bhattacharji S., Friedman G.M., Neugebauer H.J., Seilacher A. (Eds.) Lecture Notes in Earth Sciences. Springer-Verlag, Berlin Heidelberg, pp.1-210.

Schöpfer M.P.J., Arslan A., Walsh J.J., Childs C. (2011) Reconciliation of contrasting theories for fracture spacing in layered rocks. Journal of Structural Geology, 33, 551-565.

Sheppard T.H., Houghton R.D., Swan A.R.H. (2006) Bedding and pseudo-bedding in the early Jurassic of Glamorgan: deposition and diagenesis of the Blue Lias in South Wales. Proceedings of the Geologists' Association, 117, 249-264.

Sowers G. M. (1972) Theory of spacing of extension fracture. Engineering Geology Case Histories, 9 , 27-52

Spiegel M.R., Stephens L.J. (1999) Schaum's Outline of Theory and Problems of Statistics. Third ed., Schaum's Office Series, New York.

Stauffer D., Aharônî A. (1994) Introduction to Percolation Theory. Rev. second ed., Taylor \& Francis Ltd, London.

Tappin D.R., Chadwick R.A., Jackson A.A., Wingfield R.T.R., Smith N.J.P. (1994) The Geology of Cardigan Bay and the Bristol Channel, United Kingdom Offshore Regional Report. British Geological Survey, London.

van Hoorn B. (1987) The South Celtic Sea/Bristol Channel Basin: Origin, deformation and inversion history. Tectonophysics, 137, 309-334.

Vermilye J.M., Scholz C.H. (1999) Fault propagation and segmentation: Insight from the microstructural examination of a small fault. Journal of Structural Geology, 21, 1623-1636.

Weedon G.P. (1986) Hemipelagic shelf sedimentation and climatic cycles: The basal Jurassic (Blue Lias) of South Britain. Earth and Planetary Science Letters, 76, 321-335.

Westphal H., Head M.J., Munnecke A. (2000) Differential diagenesis of rhythmic limestone alternations supported by palynological evidence. Journal of Sedimentary Research, 70, 715725 .

Whittaker A., Green G.W. (1983) Geology of the Country around Weston-super-Mare. Geological Survey of Great Britain, Institute of Geological Sciences, Her Majesty's Stationary Office, London.

Wilson D., Davies J.R., Fletcher C.J.N., Smith M. (1990) Geology of the South Wales Coalfield, Part VI, the Country Around Bridgend. Second ed., British Geological Survey, London. 
Wobber F.J. (1967) Post-depositional structures in the Lias, South Wales. Journal of Sedimentary Petrology, 37, 166-174.

Wu H.Q., Pollard D.D. (1995) An experimental-study of the relationship between joint spacing and layer thickness. Journal of Structural Geology, 17, 887-905. 


\title{
-Chapter 7-
}

\section{Effects of stress barriers on reservoir permeability in layered rocks: A case study of Blue Lias rhythms (Bristol Channel Basin, UK)}

\author{
Filiz Afşar a, ${ }^{\text {a, }}$ Hildegard Westphal ${ }^{\text {b, c }}$, Sonja L. Philipp ${ }^{\text {a }}$ \\ ${ }^{a}$ University of Göttingen, Geoscience Centre (GZG), Structural Geology and Geodynamics, Goldschmidtstraße \\ 3, D-37077 Göttingen, Germany \\ ${ }^{b}$ Leibniz Centre for Tropical Marine Ecology GmbH (ZMT), Biogeochemistry and Geology, Geoecology and \\ Carbonate Sedimentology, Fahrenheitstraße 6, D-28359 Bremen, Germany \\ ${ }^{c}$ University of Bremen, Department of Geosciences, Klagenfurter Straße, D-28359 Bremen, Germany \\ *Correspondence: filiz.afsar@geo.uni-goettingen.de
}

American Association of Petroleum Geologists Bulletin (in review since 13.08.2014)

\begin{abstract}
In layered and fractured reservoirs characterised by low matrix permeability, fracture networks control the main fluid flow paths. However, fracture permeability varies considerably from layer to layer due to different stress barriers, for example, mechanical properties change between layers. Therefore it is crucial to understand the effects of small scaled lithological heterogeneities on fracture propagation and arrest and to quantify these heterogeneities for the better prediction of fracture-associated permeability and fluid flow models. The studied successions belong to the Blue Lias Formation (Hettangian-Sinemurian), exposed on the coast of the Bristol Channel, United Kingdom. More than 4000 fractures in six sections with strong morphological variations in limestone-marl alternations were examined. Stress barriers were mapped based on vertical fracture terminations at and crossings through lithological contacts and extension through layers. The influence of diagenesis and sedimentary features based on observations from metre to micrometre scale were investigated, in order to define mechanical interfaces, buffers and units for layered rocks. The results show that stress barriers are related to (1) the contrast in rock properties (2) the nature of the contacts between different lithologies, (3) bed thicknesses and (4) bed heterogeneities. Since not all lithological contacts inhibit fracture extension, the term 'mechanical interface' is defined in this study based on fracture terminations at contacts. If marls reveal greater thicknesses $(>0.20 \mathrm{~m})$, exhibit $>50 \%$ fracture terminations at the top and bottom ('mechanical interface') and $<50 \%$ fractures propagate through the marl, a 'mechanical buffer' are defined. The findings demonstrate that bed characteristics (e.g. lithological contacts, thickness and heterogeneities) are highly variable and strongly affect vertical fracture extension. This makes predictions of fracture network connectivity for outcrop analogue studies, more difficult. Therefore the identification of 'mechanical units', in which multiple layers act mechanically as a single unit, is crucial for the characterisation of fracture networks in layered rocks. Consequently, we defined a mechanical unit when there are no mechanical buffers and the layers have almost the same $\mathrm{CaCO}_{3}$ content.
\end{abstract}




\subsection{Introduction}

Reservoirs in many cases are characterised by mechanical layering, i.e. mechanical property changes between layers ('layered naturally fractured reservoirs'; cf. Aguilera, 2000). In reservoirs consisting of layered rocks, however, fracture permeability varies considerably from layer to layer due to different kinds of stress barriers (Philipp et al., 2013; Afşar et al., 2014; see chapter 9 and 6 for details). In such reservoirs, the fluid flow is largely controlled by the permeability of their fracture networks ('fractured reservoirs'; cf. Nelson, 1985). Provided that fractures in such 'layered reservoirs' are well interconnected, the fracture network may reach the percolation threshold (cf. Stauffer and Aharônî, 1994; cf. Aguilera, 2000). Many reservoirs for petroleum, natural gas, ground or geothermal water are both fractured and layered reservoirs. Particularly, limestone-marl alternations (LMA) could contain oil-shale beds, where hydrocarbons are generated, stored and trapped in the same layer. Oil-shale beds of the Blue Lias Formation, for example, crop out in Kilve (Somerset) and the Kimmeridge Clay of onshore eastern and southern England also contains oil-shale beds (Harvey and Gray, 2011).

Extension fracturing in layered rocks, in general, starts at initial flaws (i.e. mechanical weak points) in stiff beds (cf. Mandl, 2005). Flaws in rocks are discontinuities, such as cavities, micro-cracks and fossil boundaries (e.g. Pollard and Aydin, 1988). Differences in the elastic properties due to the heterogeneous rocks in turn cause different stress concentrations (e.g. Gudmundsson, 2011). In cases of extension fractures perpendicular to bedding planes, fractures may be initiated that subsequently propagate parallel to the minimum principal stress (e.g. Narr and Suppe, 1991). However, the contrast in mechanical rock properties (e.g. material toughness and/or rock stiffness) can affect fracture arrest and limit fracture connectivity (e.g. Erdogan, 1972; Biot et al., 1983; Helgeson and Aydin, 1991). Thus, fractures in layered rocks tend to be largely confined to individual layers (i.e. they are stratabound), compared with fractures in massive rocks (Odling et al., 1999). The sizes of non-stratabound fractures, however, cover a wider range and are vertically persistent over several layers (Odling et al., 1999). Wide-ranging fracture systems can comprise both stratabound and non-stratabound fractures or the fracture system type may change with scale (Odling et al., 1999). For example, several layers (i.e. small scale) may act mechanically as one single unit ('mechanical unit') with high percentages of non-stratabound fractures (Afşar et al., 2014; see chapter 6 for details). The meaning of the term 'mechanical unit' varies in the literature depending on different rock bodies (i.e. massive or layered rocks). An early 
description of 'mechanical unit' was based on lithostratigraphic units (defined as 'mechanicalstratigraphic units') in massive rocks (Corbett et al., 1987). This definition was later refined for layered rocks, where single 'mechanical units' were distinguished by the interfaces between stiff and soft beds (i.e. mechanical layer boundaries) and the distance between the mechanical layer boundaries (i.e. mechanical layer thickness; Gross, 1993). Some studies define 'fracture units', i.e. groups of sedimentary beds with homogeneous fracture patterns (e.g. Laubach et al., 2009; Boro et al., 2013). In the following soft beds are referred in this study to 'marl interbeds' and the term 'mechanical unit' were used based on the vertical fracture extension through several layers. The nature of contacts between different lithologies can be mechanically distinguished in (1) welded and (2) non-welded contacts (Hobbs, 1967; Price, 1966). (1) Welded contacts are strongly cohesive and fractures tend to propagate collinearly through the contacts ('welded-layered model'; Hobbs, 1967). (2) In contrast, at non-welded contacts interfacial shear stress directly at the contact occurs and fractures become either arrested or offset and continue side-stepping upwards at the contacts ('slipmodel'; Price, 1966).

Six sections with strong morphological variations (ranging from limestone dominated to marl dominated) of the Blue Lias Formation (Lower Jurassic, Hettangian-Sinemurian) were investigated. The principal aim of this paper is to evaluate different stress barriers, such as (1) the contrast in rock properties, (2) contacts of different lithologies, (3) interbed thicknesses and (4) interbed heterogeneities. Stress barriers were mapped based on vertical fracture termination at and crossings through lithological contacts and extension through layers. The influence of diagenesis and sedimentary features based on observations from metre to micrometre scale were investigated, in order to define mechanical interfaces, buffers and units for layered rocks.

\subsection{Geological setting}

Rocks of the Blue Lias Formation (Hettangian-Sinemurian) are well exposed along the coastline of the Bristol Channel (UK; Fig. 7.1A) and comprise limestone-marl and/or -shale alternations with thicknesses of $150 \mathrm{~m}$ in South Wales (Wilson et al., 1990) and $175 \mathrm{~m}$ in North Somerset (Whittaker and Green, 1983). The Blue Lias Formation was deposited in the Bristol Channel Basin, which is a northerly deepening asymmetric graben bounded to the north by the Central Bristol Channel Normal Fault (Tappin et al., 1994) and the Variscan Front Thrust Fault (e.g. van Hoorn, 1987; Fig. 7.1B). 
The Bristol Channel Basin was formed by Permo-Triassic rifting processes which reactivated the Hercynian thrust zone (van Hoorn, 1987). Subsequent regional subsidence led to the formation of an epeiric ocean during the Mesozoic which was connected with the northwestern Tethys (cf. Cope, 2006). These processes are reflected by a gradual marine transgression during the uppermost Triassic to the Lower Jurassic (Wilson et al., 1990). As a consequence, a shallow marine near-shore facies directly overlies the Upper Palaeozoic basement in the area of South Wales (cf. Donovan et al., 1979). The Blue Lias Formation represents an offshore facies with water depths probably well below $100 \mathrm{~m}$ (Hallam, 1992), whereas the alternations of Wales were deposited in a more proximal environment than those of Somerset. Sedimentation rates were generally moderate to very low (Hallam, 1992) ( $>3.5 \mathrm{~cm} / \mathrm{ka}$ during steady subsidence at basin depocenters; Tappin et al., 1994 and references therein) but may have been changing drastically due to strong seasonal rainfall (Woodcock and Strachan, 2002), leading to variations in clay supply.

The origin of the LMA of the Blue Lias Formation of south-west Britain has been extensively studied (e.g. Hallam, 1960; Weedon, 1986; Sheppard et al., 2006). Although most authors agree that the alternations are primary in origin and that the role of diagenesis has been the subject of a long-standing controversy (e.g. Hallam, 1960; Weedon, 1986; Sheppard et al., 2006; Bloos and Page, 2002). Respective studies range from the formation of nodular structures during early diagenesis (Hallam, 1960) to the entirely diagenetic formation of limestones and marls by diagenetic differentiation of originally homogeneous (Bloos and Page, 2002) or partly heterogeneous lime mud with hardgrounds, indicating sedimentation breaks (i.e. omission surfaces with encrusting macrofossil assemblages; Sheppard et al., 2006). 

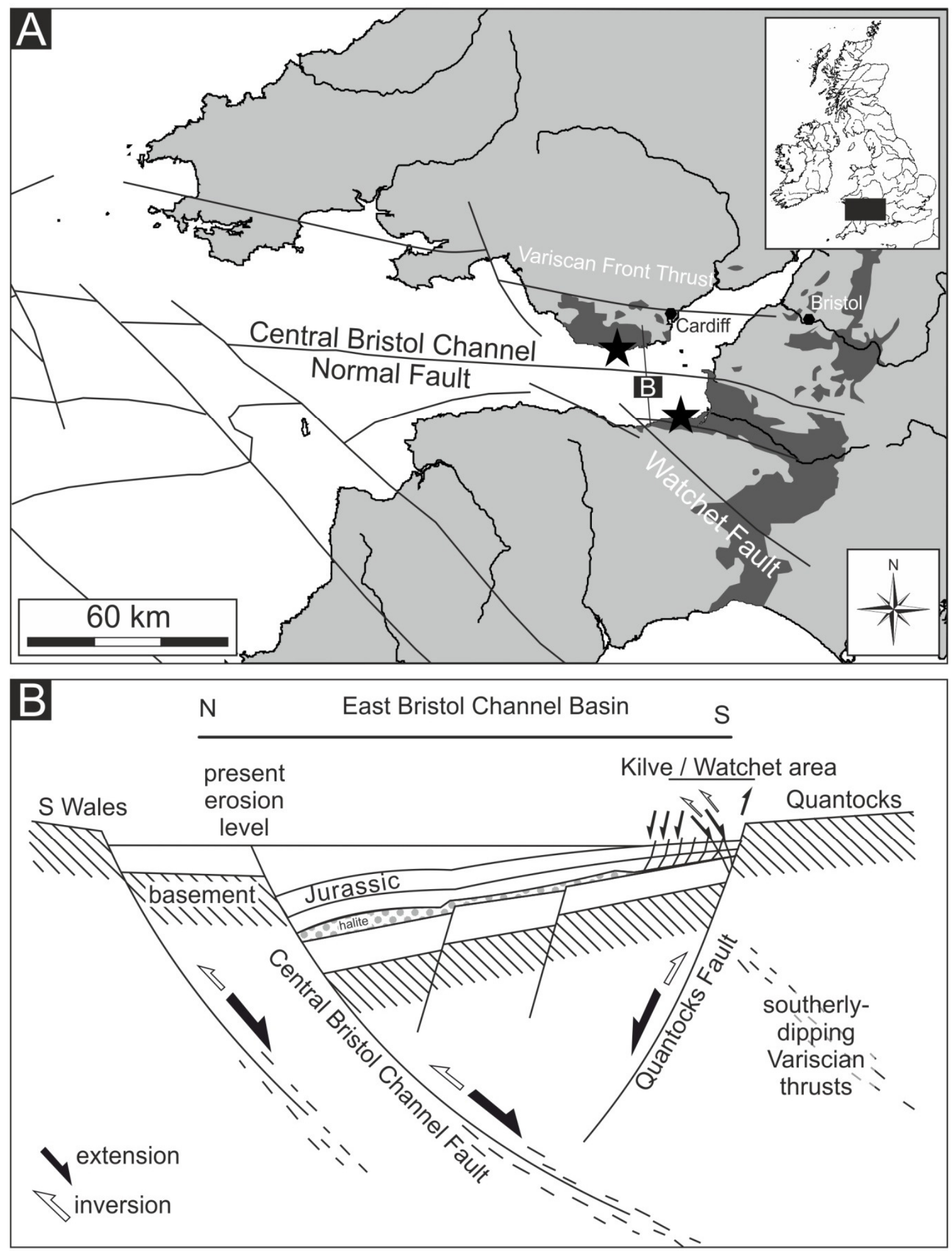

Figure 7.1: Geographic and tectonic overview of the study area. A) Location of the investigated sections (stars; cross section of the graben system is marked with a (B) along the Bristol Channel (modified after Kamerling, 1979; Tappin et al., 1994) with a generalised outcrop map of the Lias Group in grey (Blue Lias Formation is a part of the Lias Group; Cox et al., 1999); B) Cross-section of the eastern part of the Bristol Channel Basin (Stewart et al., 1997). 


\subsection{Field and laboratory methods}

The two study areas are located on the northern and southern margins of the Bristol Channel. On both sides, three sections were measured (NP1-3 in Wales; KI1, LIL2, KN3 in Somerset; Fig. 7.1A). In total, 4010 fractures were measured using the modified scan-line method described in detail in Afşar et al. (2014; see chapter 6 for details). The scan-lines were $15 \mathrm{~m}$ long and oriented parallel to the bedding and perpendicular to the main fracture set. The fracture heights were traced over multiple beds and interbeds. Seven different fracture traces were classified into two different fracture types, determining the fracture arrest at lithological contacts (fracture terminations and crossings; Fig. 7.2A,B) and the vertical extension through one or more than one layer (Fig. 7.2C; Tab. 7.1; see appendix). Fractures terminating at lithological contacts ('fracture terminations') or fractures extending through either the lithological contacts at the top and the base or at least one lithological contact ("fracture crossings') in a purely descriptive sense were distinguished (Fig. 7.2B). In contrast, the terms 'fracture propagation' and 'fracture arrest' are used to discuss the processes in fracture development. For each fracture the local bed thickness was measured.

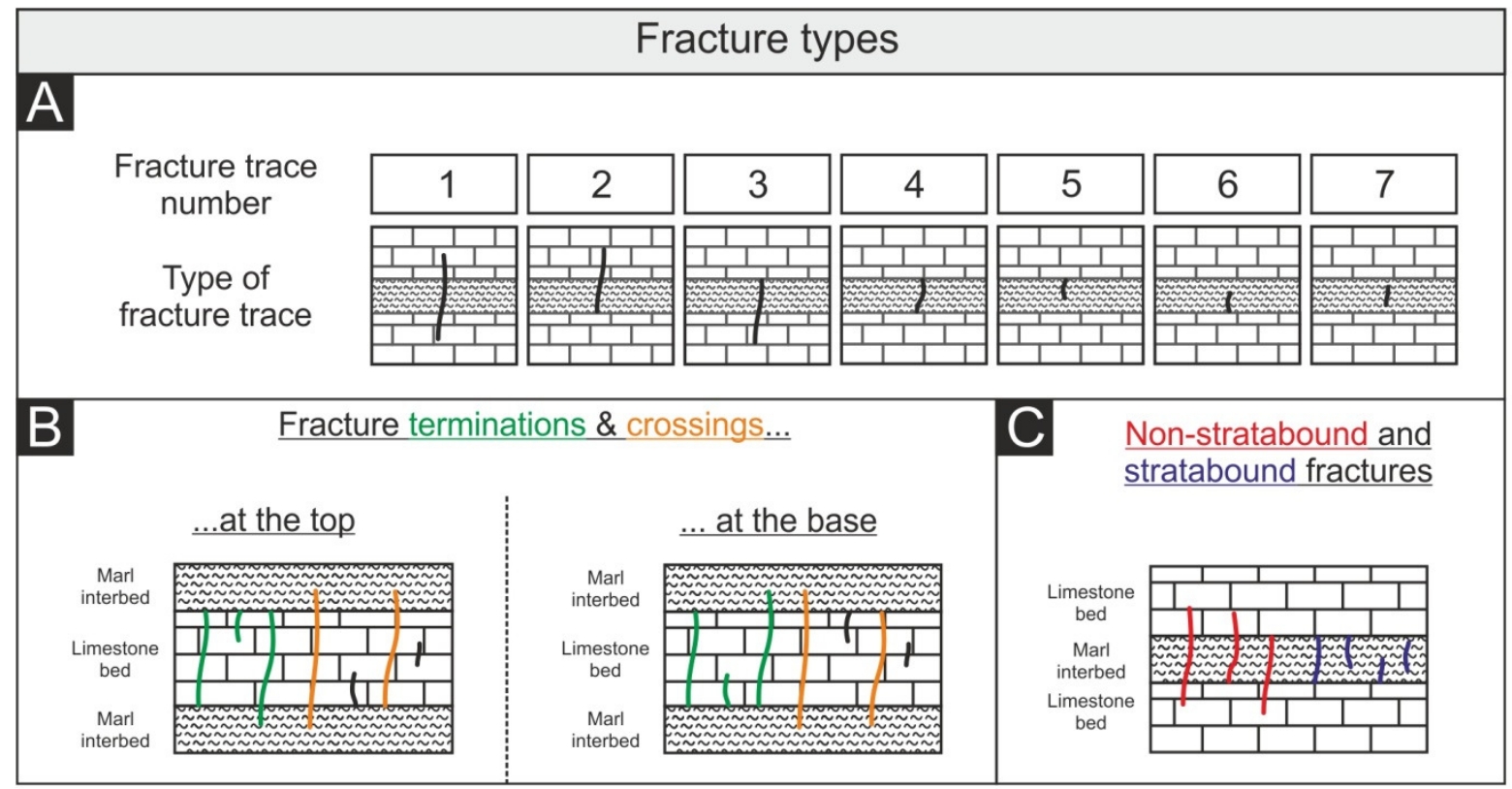

Figure 7.2: A) Seven different fracture traces with fracture trace numbers for each layer were mapped; B) Different fracture traces were classified into fracture terminations at and fracture crossings through each lithological contact; C) The vertical fracture extension was distinguished in non-stratabound fractures, which are propagating into the adjacent layer (crossed at least one lithological contact) and stratabound fractures, which are restricted to single layers. 
Sedimentological field work included the measurement of six detailed sedimentary sections and the documentation of important sedimentary features in bed-scale. In addition, petrographic analyses of 59 thin sections were performed according to Dunham's (1962) classification. Petrographical tools included observation of polished slabs and thin sections (e.g. transmitted- and polarised light microscopy). $\mathrm{CaCO}_{3}$ and $\mathrm{C}_{\text {org }}$ contents were measured on 64 samples with a Hekatech Euro Elemental Analyser (CNS; Tab. 7.2; see appendix). Rock hardness was measured in the field on limestones and marls using a portable electronic rebound hardness testing device (EquotipProceq; Tab. 7.2; see appendix). 16 samples in three selected sections were etched three minutes for limestone and five minutes for marl samples with $5 \%$ ethylenediaminetetraacetic acid (EDTA). The samples were cleaned thoroughly with distilled water and dried for several days. Gold-palladium-spattered samples were examined with the scanning electron microscope (SEM) TESCAN Vegallxmu and ZEISS LEO 1530 Gemini. For elemental analyses, an energy dispersive X-ray spectrometer (EDX) Oxford Inca coupled to the SEM was used.

\subsection{Results}

\subsubsection{Lithology and sedimentology of investigated sections}

Following Dunham's (1962) classification, the limestone beds are characterised by wackestones and, more predominant mudstones. In general, the investigated sections are poor in fossils, although a few macro- and microfossils occur in some beds. These include, among others, ammonites, bivalves, gastropods, ostracods, radiolarians, echinoderms and benthic foraminifers. Furthermore, trace fossils, such as Chondrites and Thalassinoides were observed on some bedding surfaces.

Limestone beds and marl interbeds belong to the same formation; however, they vary predominantly between the two investigated study areas (Wales and Somerset, UK). Six main lithologies were distinguished: 1) well-bedded limestones (beds with relatively planar surfaces), 2) semi-nodular limestones (beds with wavy surface at the top and/or at the base), 3) calcareous marls, 4) laminated calcareous marls, 5) regular marls and 6) laminated marls. Since this study focuses, in particular, on marl interbed characteristics, only the four marl lithologies will be described in the following. The limestone lithologies are described in detail in Afşar et al. (2014; see chapter 6 for details). Calcareous and laminated calcareous marls are both characterised by a light grey weathering colour. Laminated and regular marls, however, 
are characterised by a dark grey weathering colour. Laminated calcareous or laminated marls are indicated by laminae observed in the field or in thin sections (Fig. 7.3). Rock hardness (RE) and $\mathrm{CaCO}_{3}$ content of calcareous and laminated calcareous marls range from 216 to 352 $\mathrm{RE}$ and 44 to 82 [wt\%]; both are slightly higher in regular and laminated marls (196 to 361 $\mathrm{RE}$ and 25 to $56 \mathrm{wt} \%)$.
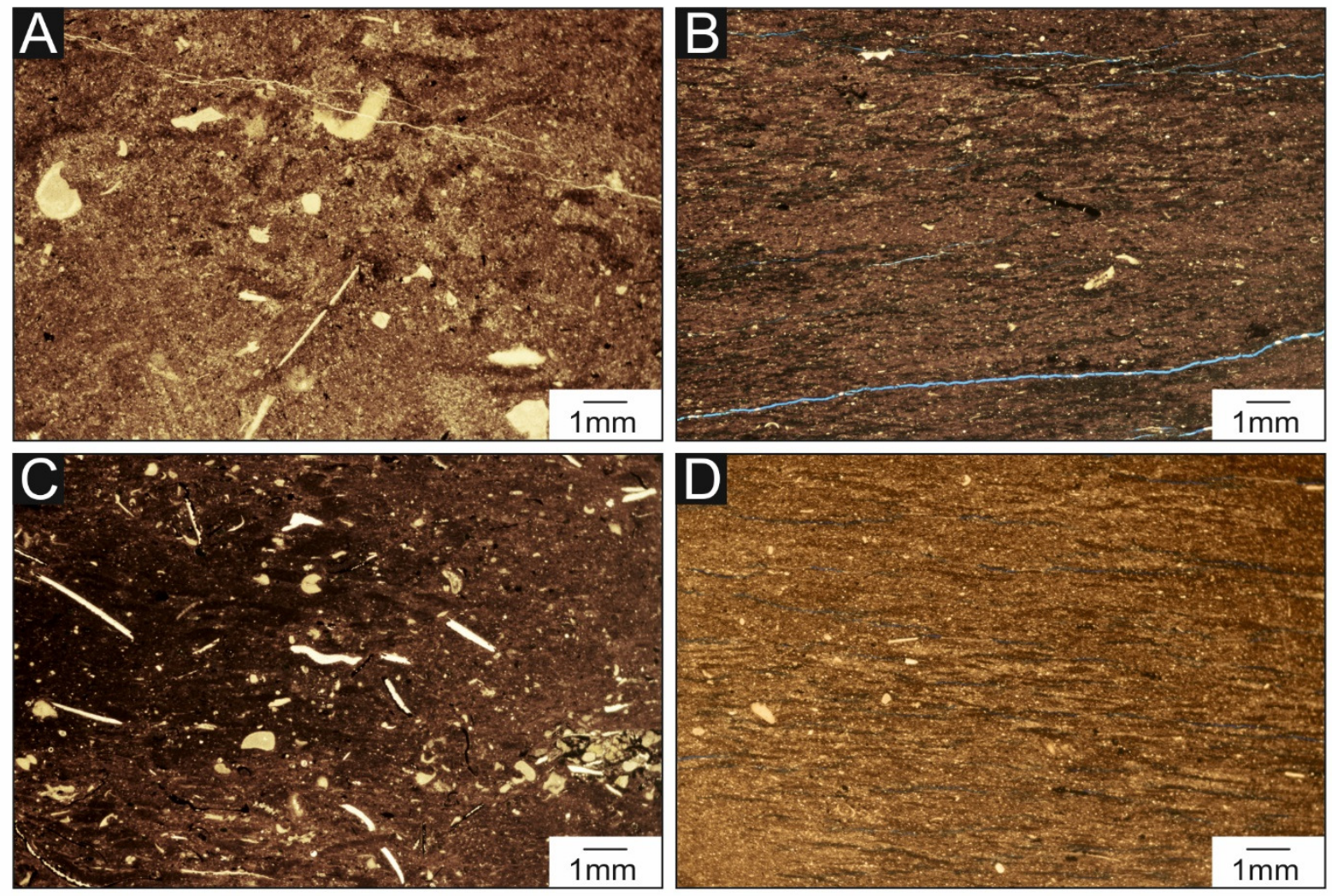

Figure 7.3: Four thin sections of each marl lithology. A) Calcareous marl $\left(\mathrm{CaCO}_{3}=60 \mathrm{wt} \%\right.$, $\mathrm{C}_{\text {org }}=0.57 \mathrm{wt} \%$, rock hardness $\left.\left.\mathrm{RE}=320\right) ; \mathrm{B}\right)$ Laminated calcareous marl $\left(\mathrm{CaCO}_{3}=46 \mathrm{wt} \%\right.$, $\mathrm{C}_{\text {org }}=0.8 \mathrm{wt} \%$, rock hardness $\left.\left.\mathrm{RE}=314\right) ; \mathrm{C}\right)$ Regular marl $\left(\mathrm{CaCO}_{3}=57 \mathrm{wt} \%, \mathrm{C}_{\text {org }}=0.55\right.$ $\mathrm{wt} \%$, rock hardness $\mathrm{RE}=218)$; D) Laminated marl $\left(\mathrm{CaCO}_{3}=64 \mathrm{wt} \%, \mathrm{C}_{\mathrm{org}}=0.79 \mathrm{wt} \%\right.$, rock hardness RE $=273$ ).

The marl interbeds in section $\underline{\mathrm{NP} 1}$ in Wales are 5-20 cm thick and comprise calcareous, laminated and regular marls (Tab. 7.2; see appendix). The marl interbeds in section NP2 in Wales are $5-15 \mathrm{~cm}$ thick and comprise laminated calcareous, laminated and regular marls (Tab. 7.2; see appendix). In contrast to the other sections in South Wales, the beds are not always well-defined: some laminated calcareous marls pinch out laterally and some limestone beds grade transitionally into laminated calcareous marl interbeds. The marl interbeds in section NP3 in Wales are 7-23 cm thick and comprise calcareous and regular marls (Tab. 7.2; see appendix). The marl interbeds in section $\underline{\mathrm{KI} 1}$ in Somerset are 8-42 cm thick and comprise calcareous, laminated (here pure shales) and regular marls (Tab. 7.2; see appendix). Within 
some marl interbeds, sharply defined colour changes, from light grey to dark grey, occur with strongly bioturbated transition (Chondrites type; Fig. 7.4A,B). Thin section analyses reveal that these bioturbated tubes are ubiquitous within marl layers as well as within limestone beds (Fig. 7.4B). Furthermore, parallel sets of dissolution seams occur in some marl/shale interbeds (Fig. 7.4C,D). These marl/shale interbeds are rich in organic carbon (16 $\mathrm{wt} \% \mathrm{C}_{\text {org }}$ ) as evidenced by the dark colour in the outcrop (Fig. 7.4D). Limestone nodules are enclosed in some calcareous marls (Fig. 7.4E). These limestone nodules are characterised by microspar which transitionally grades into the calcareous marls (Fig. 7.4F). Section LIL2 in Somerset exhibits a bedding-parallel calcite vein extending over several meters and separating two beds (Fig. 7.4G,H). The marl interbeds in section LIL2 are 5-27 cm thick and comprise laminated calcareous, calcareous and laminated marls, while those in section KN3 in Somerset are 11-36 $\mathrm{cm}$ thick and comprise laminated and calcareous marls (Tab. 7.2; see appendix). Rocks in these sections commonly contain red-brownish minerals, tentatively interpreted as secondary iron-oxides (i.e. formed due to weathering). 

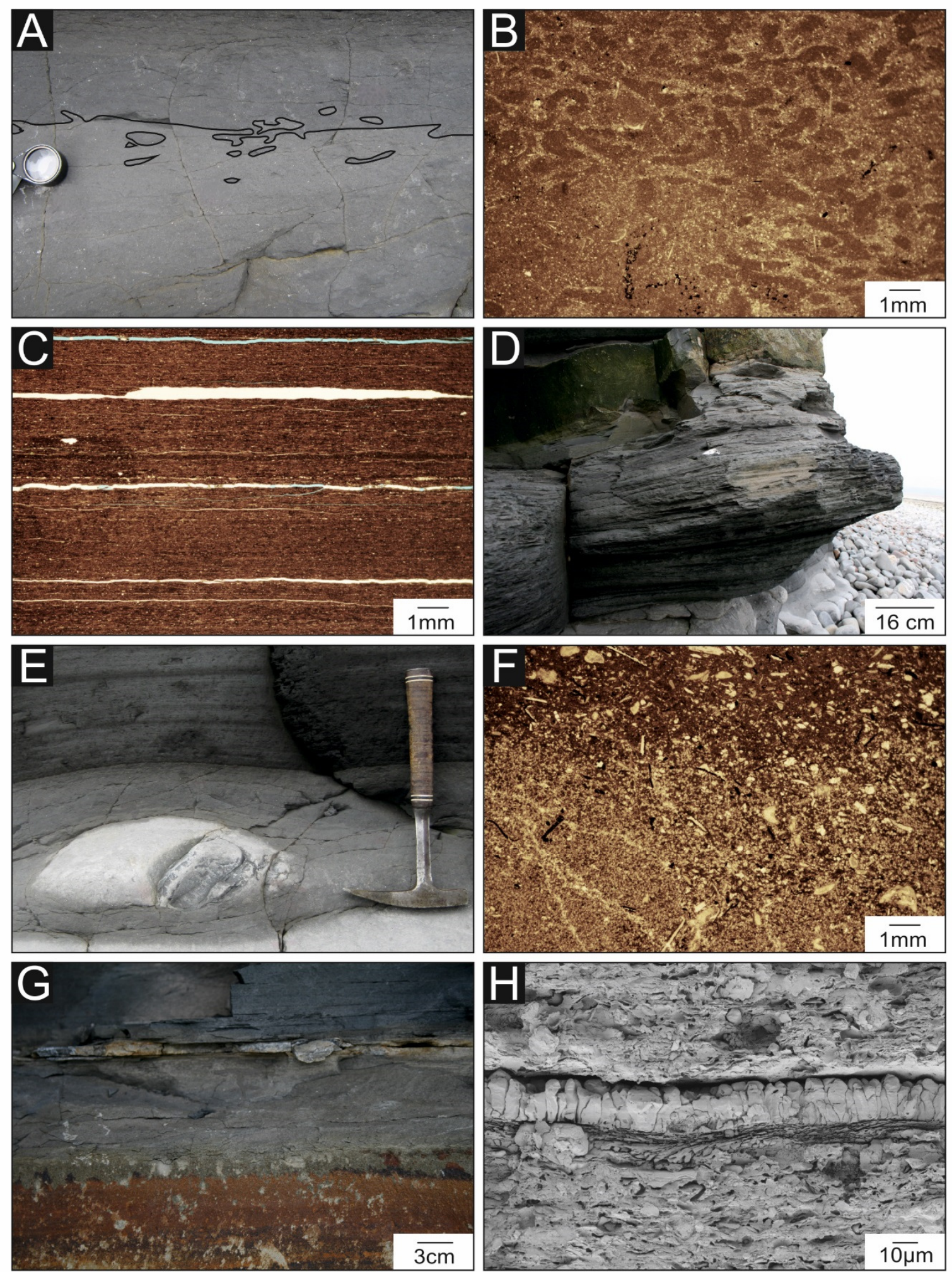

Figure 7.4: Characteristics of marl interbeds in the investigated sections. A,B) Bioturbation within calcareous marls in the field (A; retraced; loupe as scale) and in the thin section (B); C) Parallel sets of dissolution seams in the shale layer in the thin section; D) $\mathrm{C}_{\text {org }}$ rich $(16 \%)$ shale deposit, note the dark colour; E) Limestone nodule within calcareous marl (field; hammer as scale); F) Microspar in limestone nodule (lower part) transitionally grading into a marl layer (upper part); G) Bedding-parallel calcite vein in the field; H) Bedding-parallel calcite vein under SEM. The SEM sample was taken $3 \mathrm{~cm}$ below the calcite vein. 


\subsubsection{Fracture data}

The fracture database consists in total of 4010 fractures and their extension (i.e. fracture terminations vs. crossings) on 62 lithological contacts distributed over six sections (Tab. 7.1; see appendix). The percentages of fracture terminations show large dispersion independent of the $\mathrm{CaCO}_{3}$ ratio (Fig. 7.5). The $\mathrm{CaCO}_{3}$ ratio of limestones and calcareous or laminated calcareous marls is lower than the ratio of limestones and laminated or regular marls. However, the percentages of fracture terminations in calcareous marl-limestone couplets are slightly lower than in marl-limestone couplets. Term 'couplet' is generally used for marllimestone pair (cf. Einsele et al., 1991; Fig. 7.5).

Calcareous and laminated calcareous marls tend to be thinner than regular and laminated marls. Generally, fracture terminations show large dispersions and do not seem correlated to the thicknesses of adjacent marl interbeds (Fig. 7.6). However, there is a weak correlation between the percentages of non-stratabound fracture [\%] and the thicknesses of adjacent marl

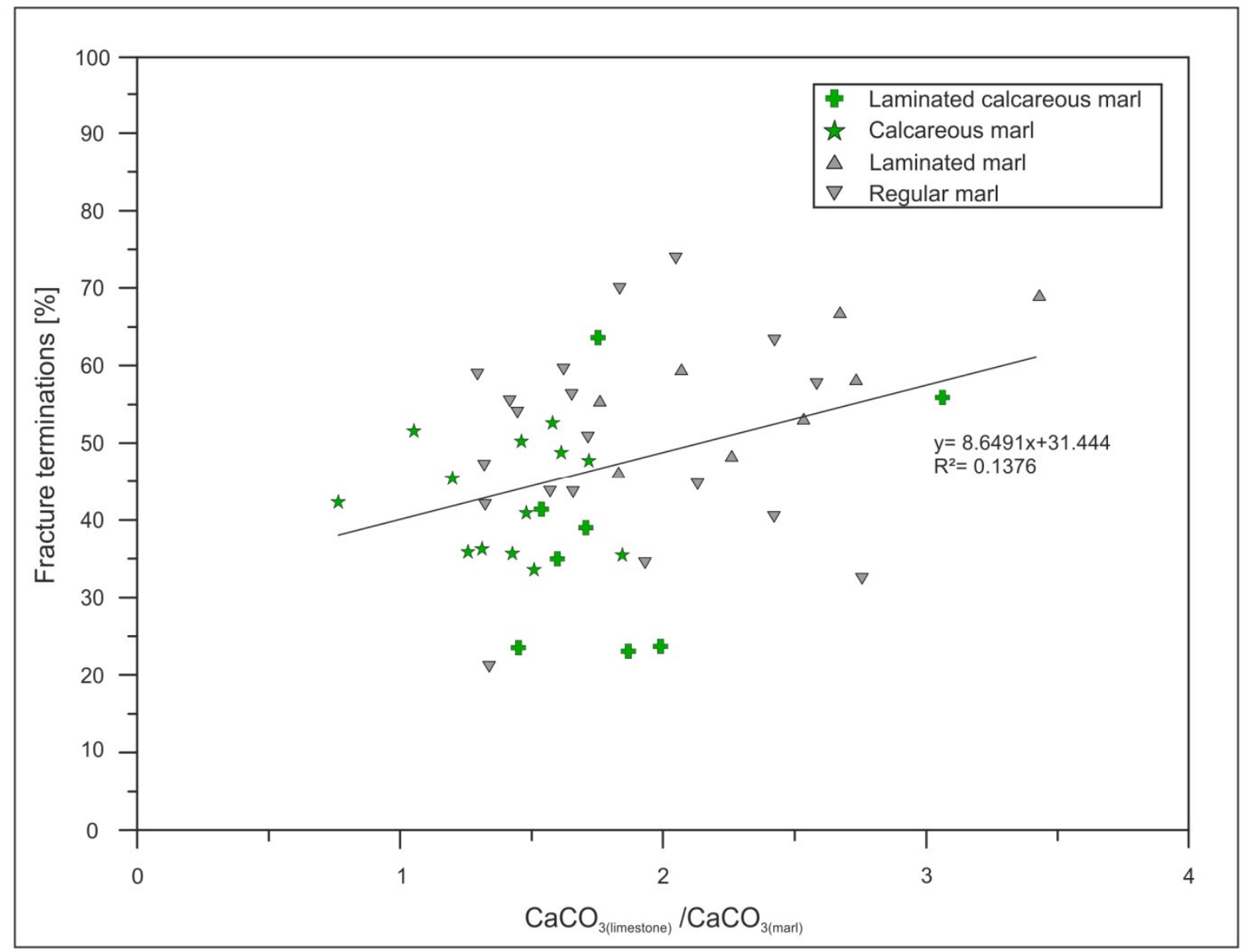

Figure 7.5: Cross-plot of fracture terminations at lithological contacts [\%] and ratio of $\mathrm{CaCO}_{3}$ content of the respective limestone bed and marl interbed. The symbols represent the four different marl lithologies (see key). 
interbeds [m] (Fig. 7.7). The coefficient of determination $\left(\mathrm{R}^{2}=0.47\right)$ indicates that ca. $47 \%$ of the percentages of non-stratabound fractures can be explained by the variation of marl thicknesses (Fig. 7.7).

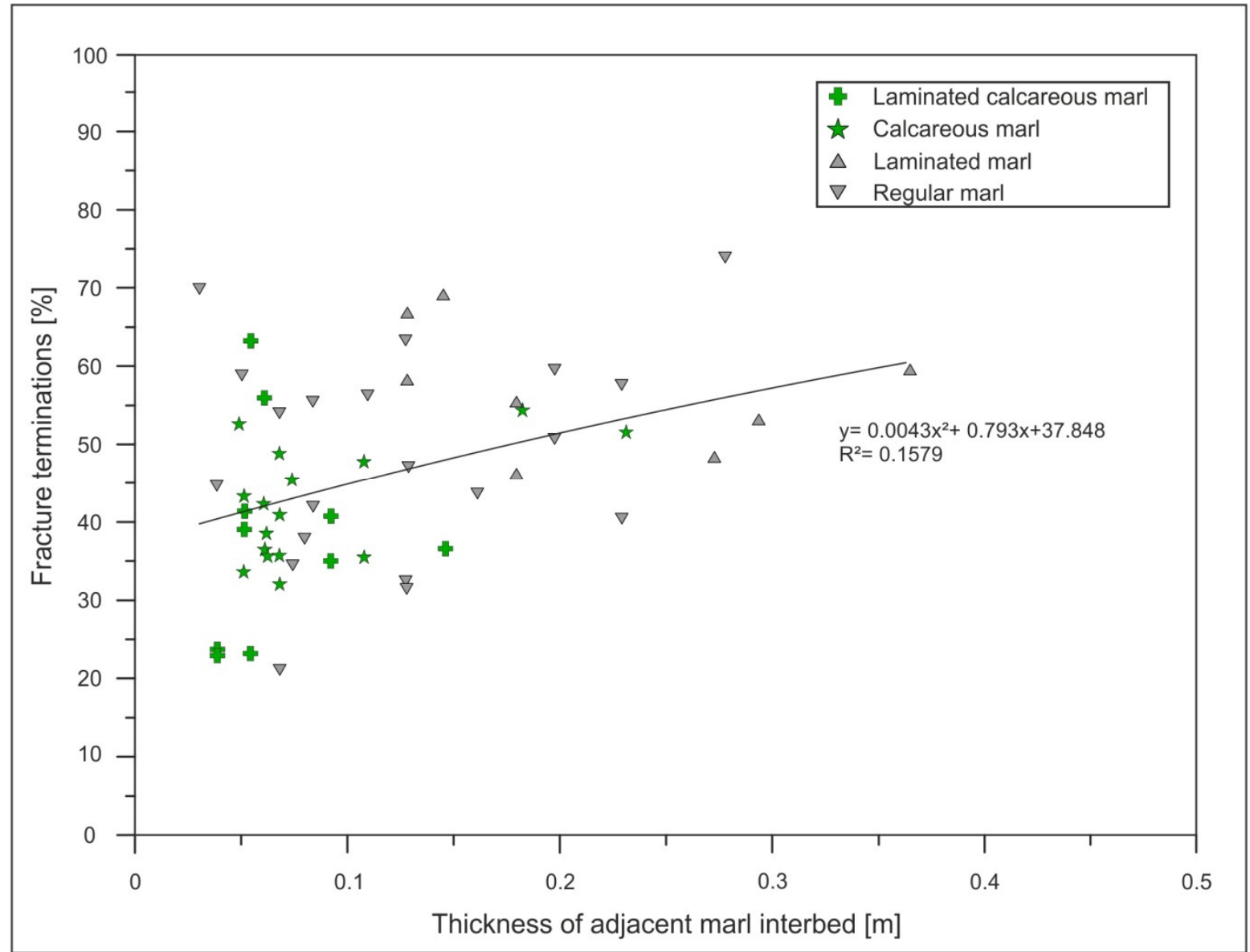

Figure 7.6: Cross-plot of fracture terminations at limestone-marl contacts [\%] with thicknesses of adjacent marl interbeds [m]. The symbols represent the four different marl lithologies (see key). 


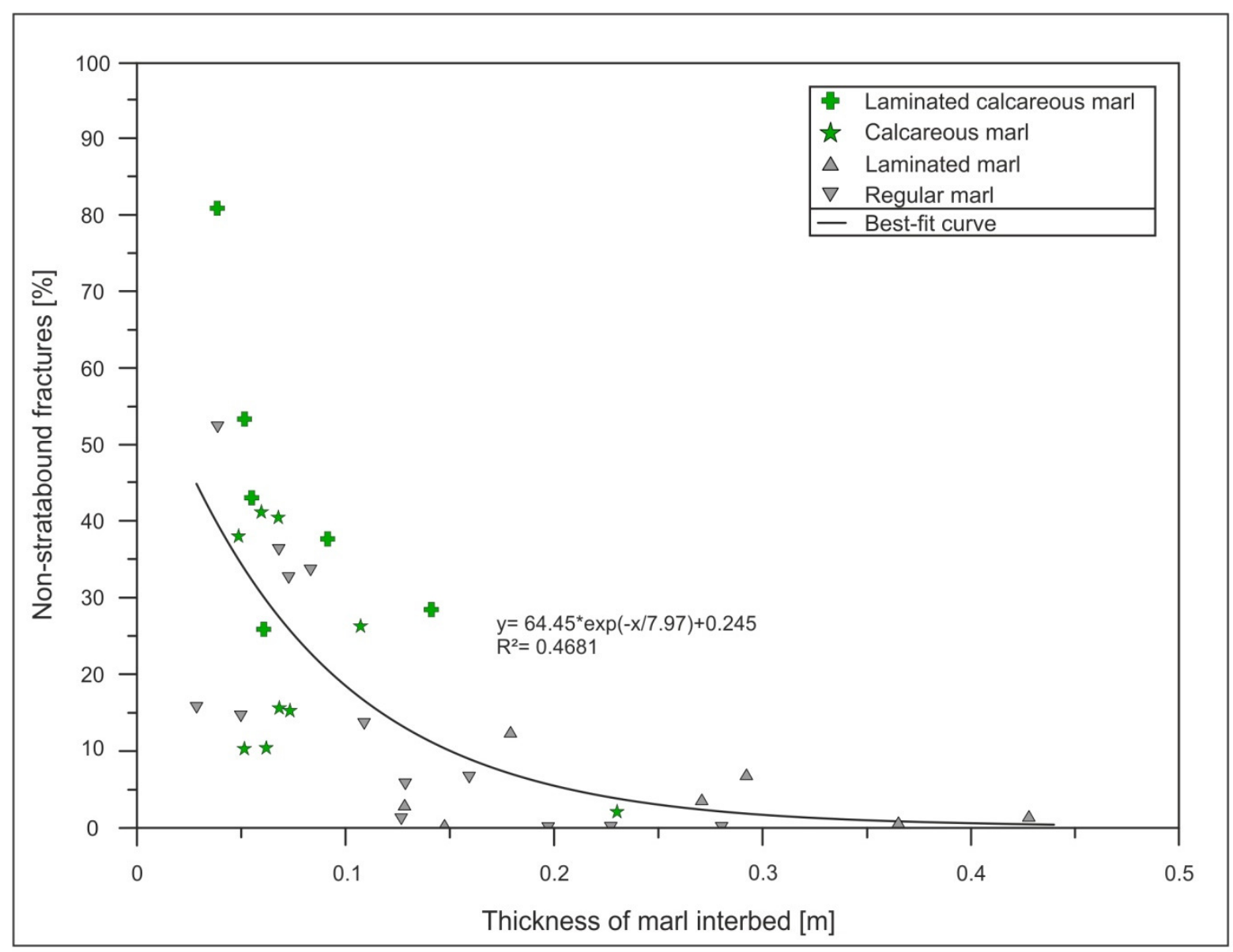

Figure 7.7: Cross-plot of non-stratabound fractures [\%] thickness of the marl interbeds [m], separated into four different marl lithologies (with different symbols, see key).

\subsection{Discussion-Effects of different stress barriers on vertical fracture propagation}

\subsubsection{Mechanical interfaces}

Generally, it has been hypothesised that the contrast between material properties, such as the stiffness of beds and interbeds, is one of the crucial reasons why lithological contacts act as stress barriers (e.g. Erdogan, 1972; Biot et al., 1983; Helgeson and Aydin, 1991). Consequently, higher contrasts between bed and interbed stiffness should lead to higher percentages of fracture terminations at lithological contacts between limestone-marl couplets. Since limestone beds commonly exhibit higher stiffnesses (i.e. the Young's moduli) than marl interbeds (cf. Bell, 2000), the $\mathrm{CaCO}_{3}$ contents were used as representative of stiffness. Some fracture terminations might be explained by the contrast of limestone-marl couplets (i.e. lower percentages of fracture terminations in limestone-calcareous marl couplets than in limestone- 
marl couplets), but not all terminations solely depend on lithological contrasts (Fig. 7.5). It seems that the contact of the two lithologies may be crucial for fracture terminations. But even though many fractures terminate at lithological contacts, not all lithological contacts necessarily terminate vertical fracture propagation. Therefore it is important to distinguish between 'lithological contacts' and 'mechanical interfaces' in layered rocks. The term 'mechanical interface' was only used for $50 \%$ of fracture terminations at the interfaces.

Whereas $70 \%$ of lithological contacts in these investigated rocks promote fracture terminations and are thus 'mechanical interfaces', $30 \%$ of lithological contacts promote fracture crossings through one or more layers and are thus 'non-mechanical interfaces' (Fig. 7.8).

One possible explanation for these different contacts could be the differential diagenesis of limestone beds and marl interbeds (cf. Westphal et al., 2000). Some limestone beds were probably not completely lithified prior to compaction, which is indicated by strongly deformed Chondrites burrow tubes at the bottoms and tops of the beds (Fig. 7.9). The migration of $\mathrm{CaCO}_{3}$ during early diagenesis was probably expedited by the action of

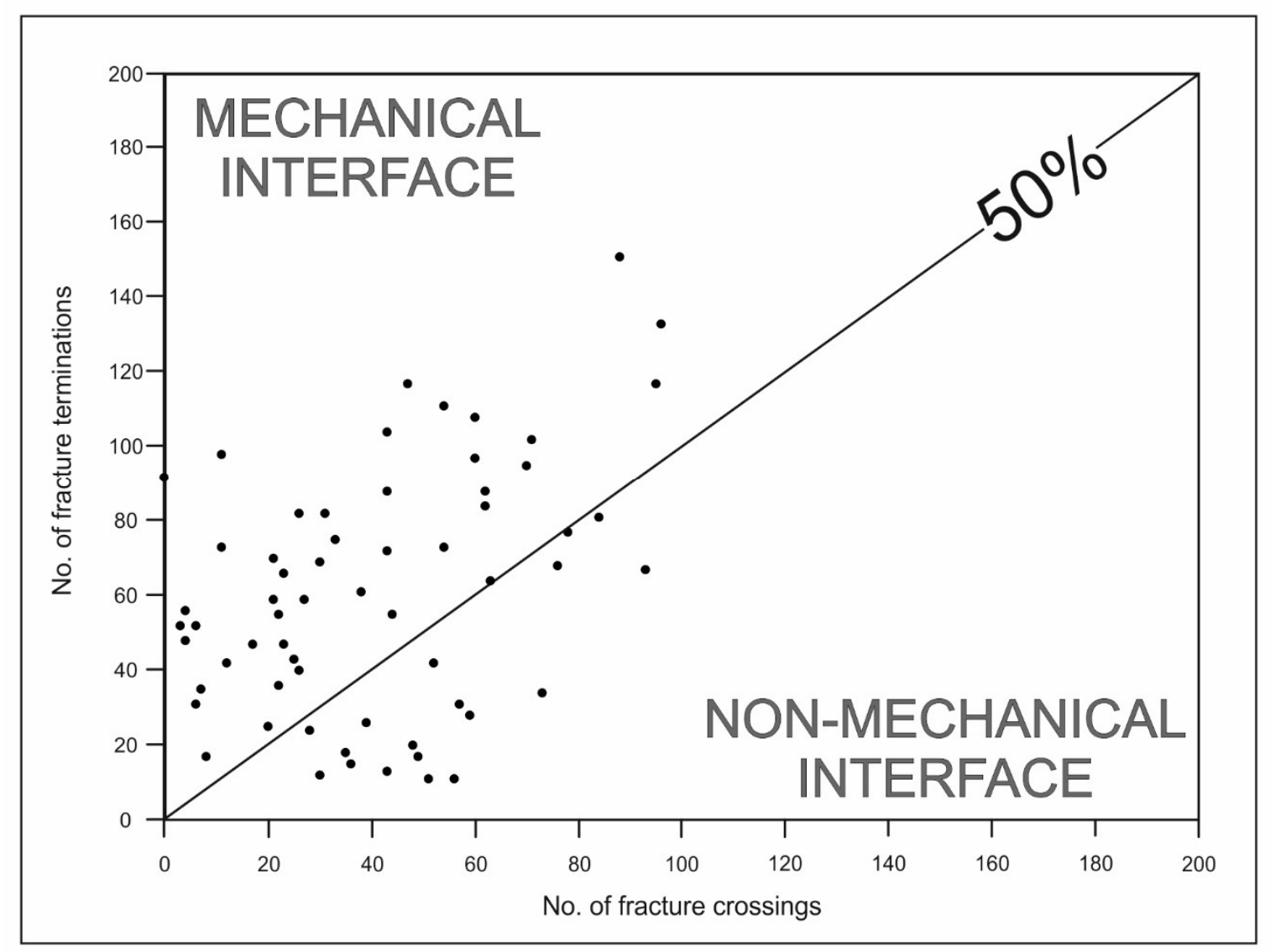

Figure 7.8: Number of fracture terminations at vs. fracture crossings through lithological contacts. When more than $50 \%$ of the fractures terminate at a lithological contact, a mechanical interface can be defined. 
burrowing organisms such as Chondrites (Wobber, 1968). Differential diagenesis, i.e. early lithification of specific parts (such as the centres of limestone beds) and late lithification of other parts (bottoms and tops of the limestone beds), probably reduce the contrast in properties between limestones and marls and thus enhance welded contacts of limestone-marl couplets and thus do not act as stress barriers (Fig. 7.9). Since these burrow tubes are very often compacted at limestone-marl contacts, the complete area below and above the contact may act as a stress barrier zone with the result that many fractures are already confined to the specific undeformed centres of the limestone beds.

A further example of how diagenetic alternation can modify the bond of lithological contacts is that some nodules or limestone beds transitionally grade into marl layers (Fig. 7.4E,F), which consequently leads to more welded contacts, as well. The presence of neomorphised recrystallised calcite within these nodules in section KI1 and within the limestone beds in section LIL2 in Somerset represents diagenetic overprinting of the initial facies (Fig. 7.4E,F). One example of non-welded contacts is the contact between beds F and G in Section LIL2 (Fig. 7.4G,H; Fig. 7.10). This contact exhibits a bedding-parallel calcite vein extending over

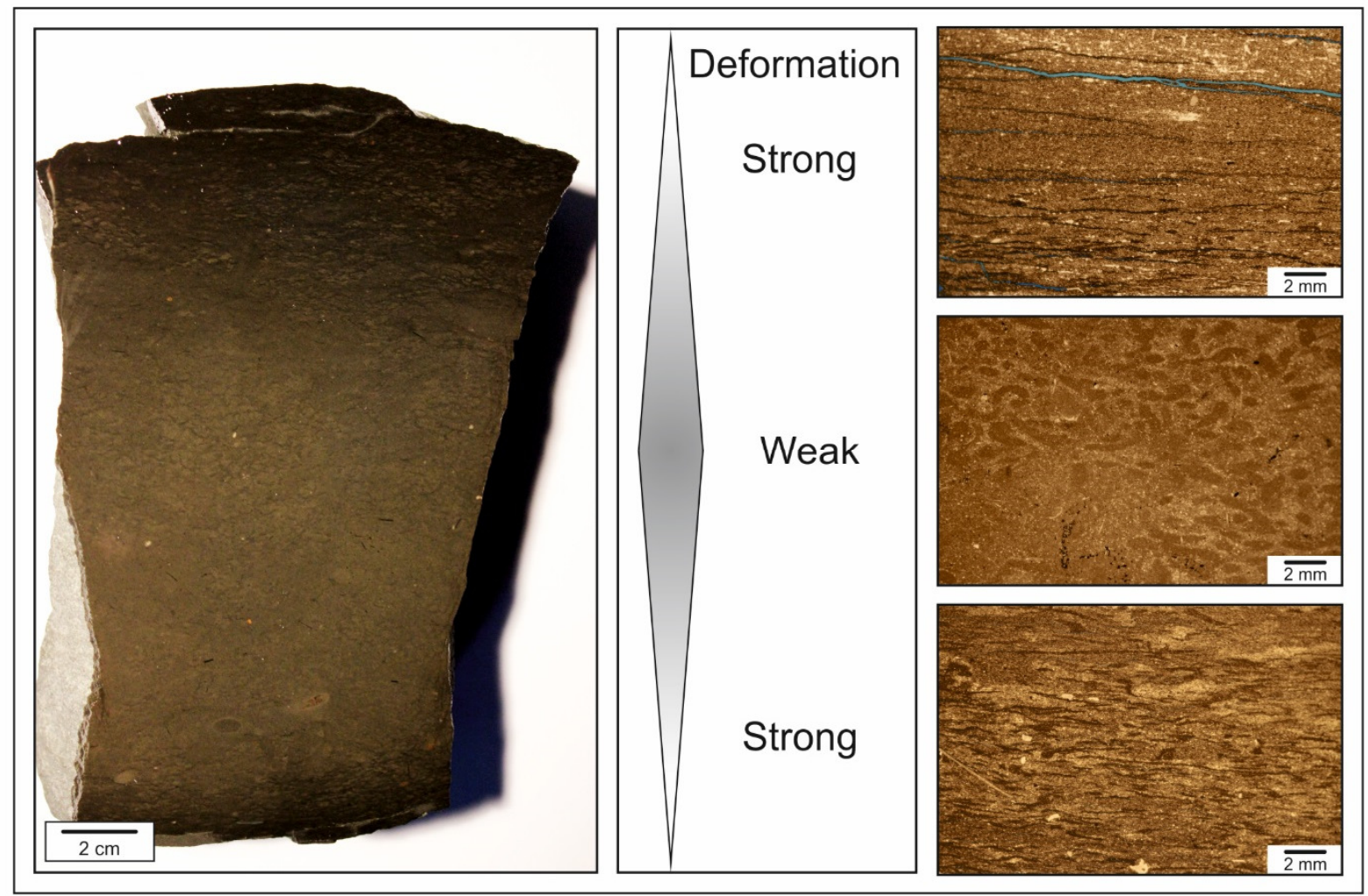

Figure 7.9: Well-bedded limestone with strongly deformed bioturbation tubes at the top and bottom of the bed and undeformed bioturbation tubes at the centre. Thin section micrographs (to the right) illustrate comparably deformed samples. 
several meters, causing low percentages of fracture crossings and high percentages of fracture terminations (Fig. 7.4G,H).

Considering all sections of LMA with different morphological variations, sections with more well-bedded limestones (e.g. section NP1) and more thick marl interbeds (e.g. section KI1) or with the same marl/limestone ratio (i.e. the sum of all limestone thicknesses divided by the sum of all marl thicknesses within one section) (e.g. section LIL2) reveal higher percentages of fracture terminations at lithological contacts (Fig. 7.10B; Fig. 7.11B). In contrast, when the lithological contacts tend to be more irregular (such as in cases of semi-nodular limestones; e.g. section NP3) and the section consists of more limestone beds than marl interbeds (e.g. section NP2) fewer fractures terminate at lithological contacts (Fig. 7.11B). Since weakness planes (i.e. in this case lithological contacts) are more irregular in semi-nodular limestones, slip of a weakness plane may be disabled, stresses can be better transmitted across interfaces and thus fractures may propagate through more than one layer (Afşar et al., 2014; see chapter 6 for details).

Consequently, the termination of most fractures at limestone-marl contacts is not directly linked to the contrasting $\mathrm{CaCO}_{3}$ contents (Fig. 7.5). Therefore it appears to be more important whether or not the contacts are welded. With this insight of real field data, theoretical models of Price (1966) and Hobbs (1967) can be applied for explanation of non-welded or welded contacts, considering either interfacial shear stress directly at the contact between stiff and soft layer ('slip' model; Price, 1966) or strong cohesive bonding excluding any interfacial slippage at contacts ('welded-layered model'; Hobbs, 1967). 


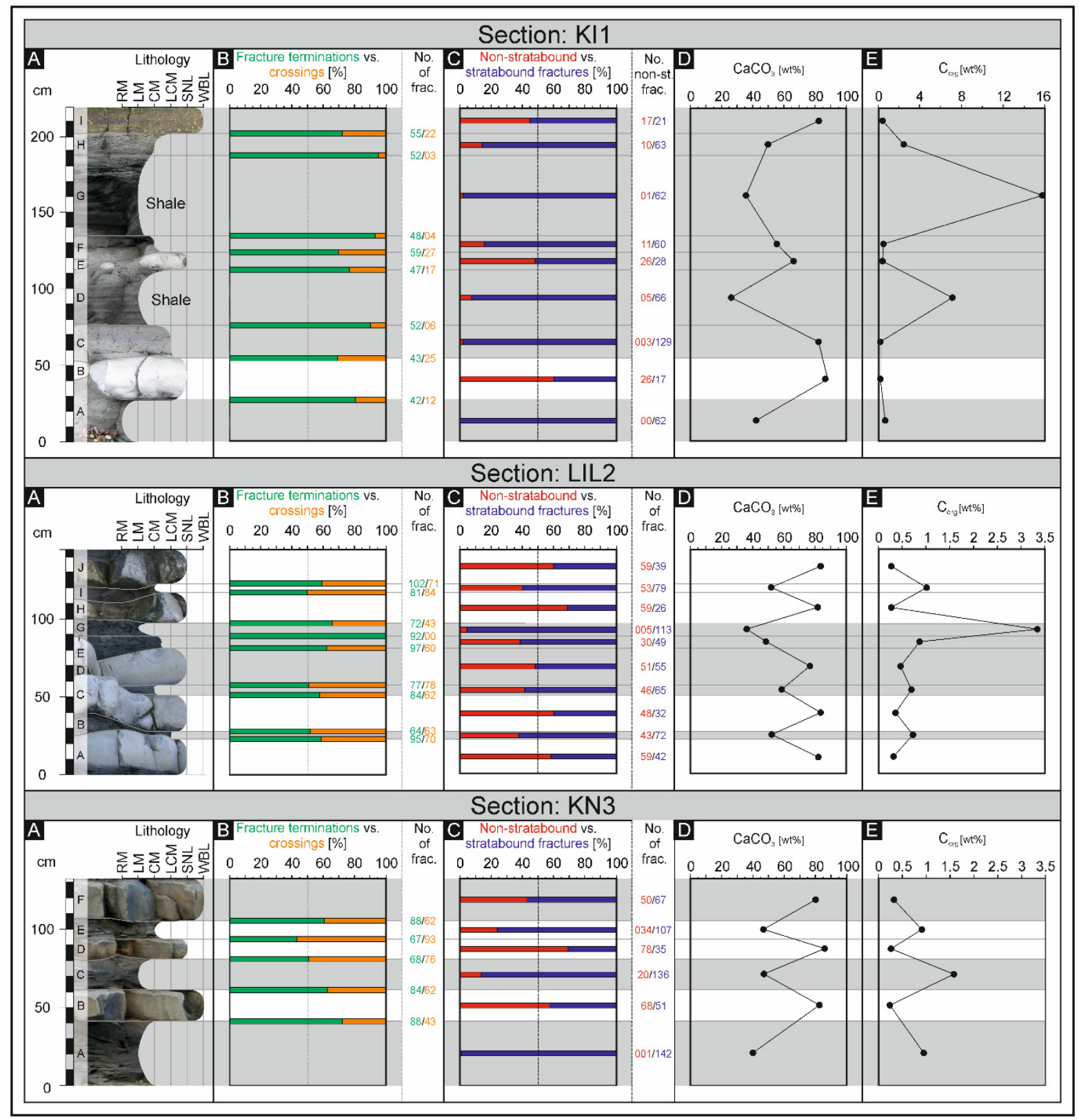

Figure 7.10: Sections KI1, LIL2 and KN2 located in Somerset. Grey areas represent 'mechanical buffers' that satisfy the criterion: $>50 \%$ fracture terminations at top and bottom and $<50 \%$ non-stratabound fractures within the respective bed or interbed. A) Sedimentological sections; the break-off illustrates differences in lithology and is not scaled (WBL $=$ well-bedded limestones, $\mathrm{SNL}=$ semi-nodular limestones, $\mathrm{CM}=$ calcareous marls, $\mathrm{LCM}=$ laminated calcareous marls, $\mathrm{RM}=$ regular marls, $\mathrm{LM}=$ laminated marls); $\mathrm{B}$ ) Percentages and number of fracture terminations at lithological contacts in green and fracture crossings through lithological contacts in orange; C) Percentages and number of nonstratabound fractures in red and stratabound fractures in blue; D) Percentages of $\mathrm{CaCO}_{3}$ for each bed and interbed; E) Percentages of $\mathrm{C}_{\text {org }}$ for each bed and interbed. 


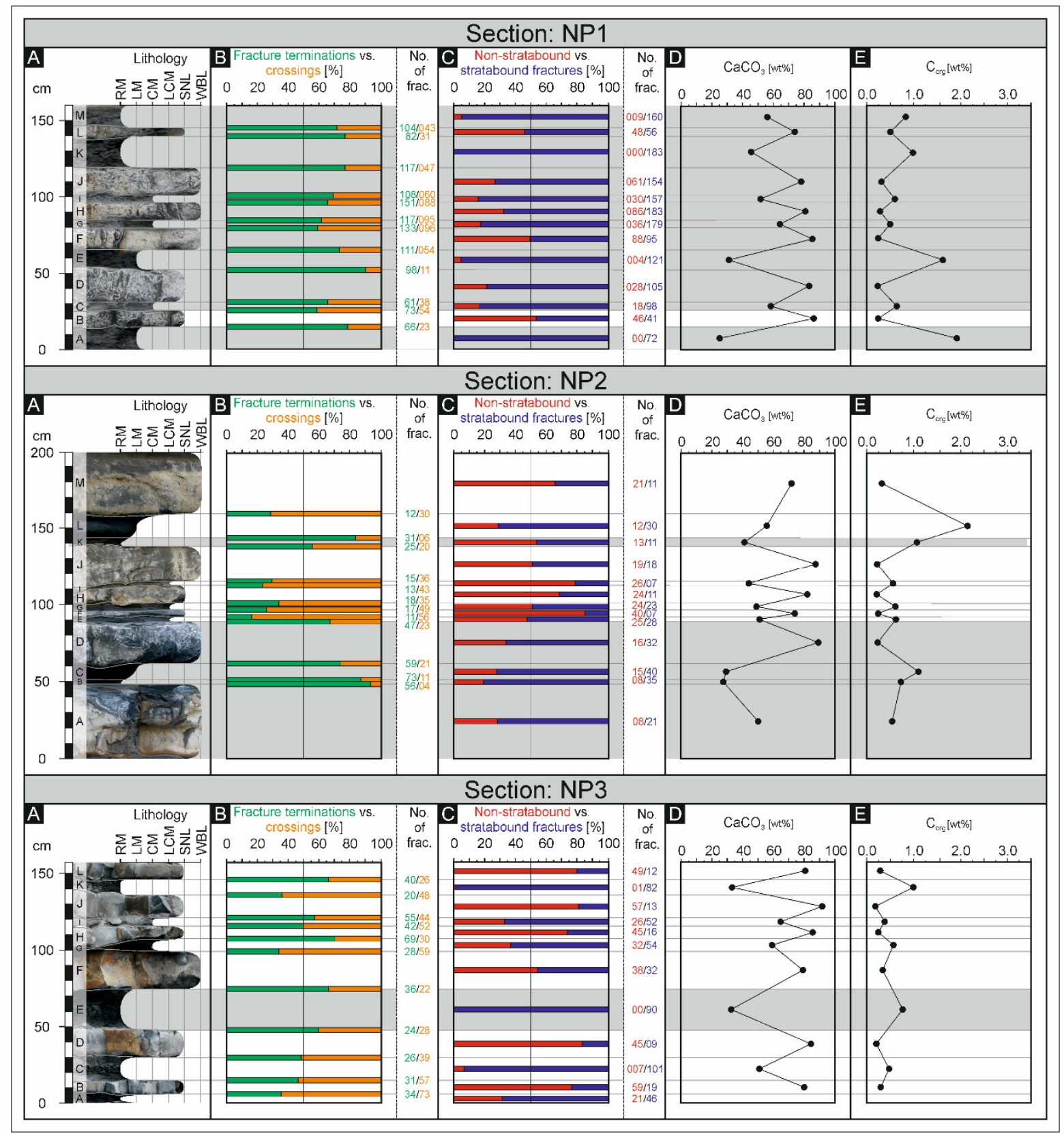

Figure 7.11: Sections NP1, NP2 and NP3 located in Wales. Grey areas represent 'mechanical buffers' that satisfy the criterion: $>50 \%$ fracture terminations at top and bottom and $<50 \%$ non-stratabound fractures within the respective bed or interbed. A) Sedimentological sections; the break-off illustrates differences in lithology and is not scaled (WBL = well-bedded limestones, $\mathrm{SNL}=$ semi-nodular limestones, $\mathrm{CM}=$ calcareous marls, $\mathrm{LCM}=$ laminated calcareous marls, $\mathrm{RM}=$ regular marls, $\mathrm{LM}=$ laminated marls); B) Percentages and number of fracture terminations at lithological contacts in green and fracture crossings through lithological contacts in orange; C) Percentages and number of non-stratabound fractures in red and stratabound fractures in blue; D) Percentages of $\mathrm{CaCO}_{3}$ for each bed and interbed; E) Percentages of $\mathrm{C}_{\text {org }}$ for each bed and interbed. 


\subsubsection{Interbed thicknesses}

If LMA are subject to remote horizontal tension, stiff beds are likely to take up most of the tensile stresses, while soft layers (hereinafter referred to as interbeds) tend to act as stress barriers (Gudmundsson and Brenner, 2001; Philipp et al., 2013; see chapter 9 for details). Additionally, due to differential compaction between limestones and marls, the soft marl interbeds undergo great layer-parallel compression, which prevents vertical fracture propagation through contacts (e.g. van Eekelen, 1982; Teufel and Clark, 1984). The thicknesses of adjacent soft interbeds may affect fracture termination at lithological contacts; in cases of thin adjacent interbeds, the percentages of fracture terminations show larger dispersion than in thicker adjacent interbeds (Fig. 7.6). Figure 7.6 reveals that most fractures do not terminate at respective lithological contacts, but rather propagate into adjacent soft interbeds.

Although the correlation between non-stratabound fractures [\%] and the thickness of marl interbeds [m] appears to be better (Fig. 7.7), $47 \%$ of the fracture crossings can be explained by the thickness of these interbeds. Rijken and Cooke (2001) state that for soft interbeds thinner than $0.2 \mathrm{~m}$, most fractures still propagate through. This is in accordance with the results of this study where for marl interbeds with thicknesses $<0.2 \mathrm{~m}$ more than $80 \%$ of the fractures propagate through the respective beds (Fig. 7.7). The percentages of non-stratabound fractures in marls smaller than $0.20 \mathrm{~m}$ in thickness show, however, wide variation (Fig. 7.7). When marl interbeds reveal greater thicknesses (maximum interbed thickness $=0.2 \mathrm{~m}$ ) and exhibit $>50 \%$ fracture terminations at the top and bottom of marl interbeds and $<50 \%$ fractures propagate through the entire marl interbed, a 'mechanical buffer' can be defined (Fig. 7.10; Fig. 7.11; grey area). Considering the whole successions, sections with more wellbedded limestones (e.g. section NP1; Fig. 7.11A) or more thick marl interbeds (e.g. section KI1; Fig. 7.10A) show more mechanical buffers than sections with more semi-nodular limestones (e.g. section NP2, NP3; Fig. 7.11A).

\subsubsection{Interbed heterogeneities}

The decisive factors affecting fracture propagation may change with interbed thickness. This implies that the thinner the interbed, parameters such as heterogeneities (e.g. the occurrence of bioturbation) play a more crucial role in fracture arrest. Chondrites are very common in the Blue Lias Formation in Wales and are regularly distributed in limestones and marls (Fig. 
7.12). However, they occur in different deformation stages from undeformed, well-distributed tubes, indicating very early lithification to strongly deformed tubes, which look like wispy seams (Fig. 7.12). Such wavy or crinkled laminae are indicated by bioturbation and are thus diagenetic pseudolaminations (e.g. Kent, 1936; Sujkowski, 1958; Noble and Howells, 1974; Ricken, 1986) which mechanically have the same effect on fractures as true depositional lamination (Fig. 7.4C,D).

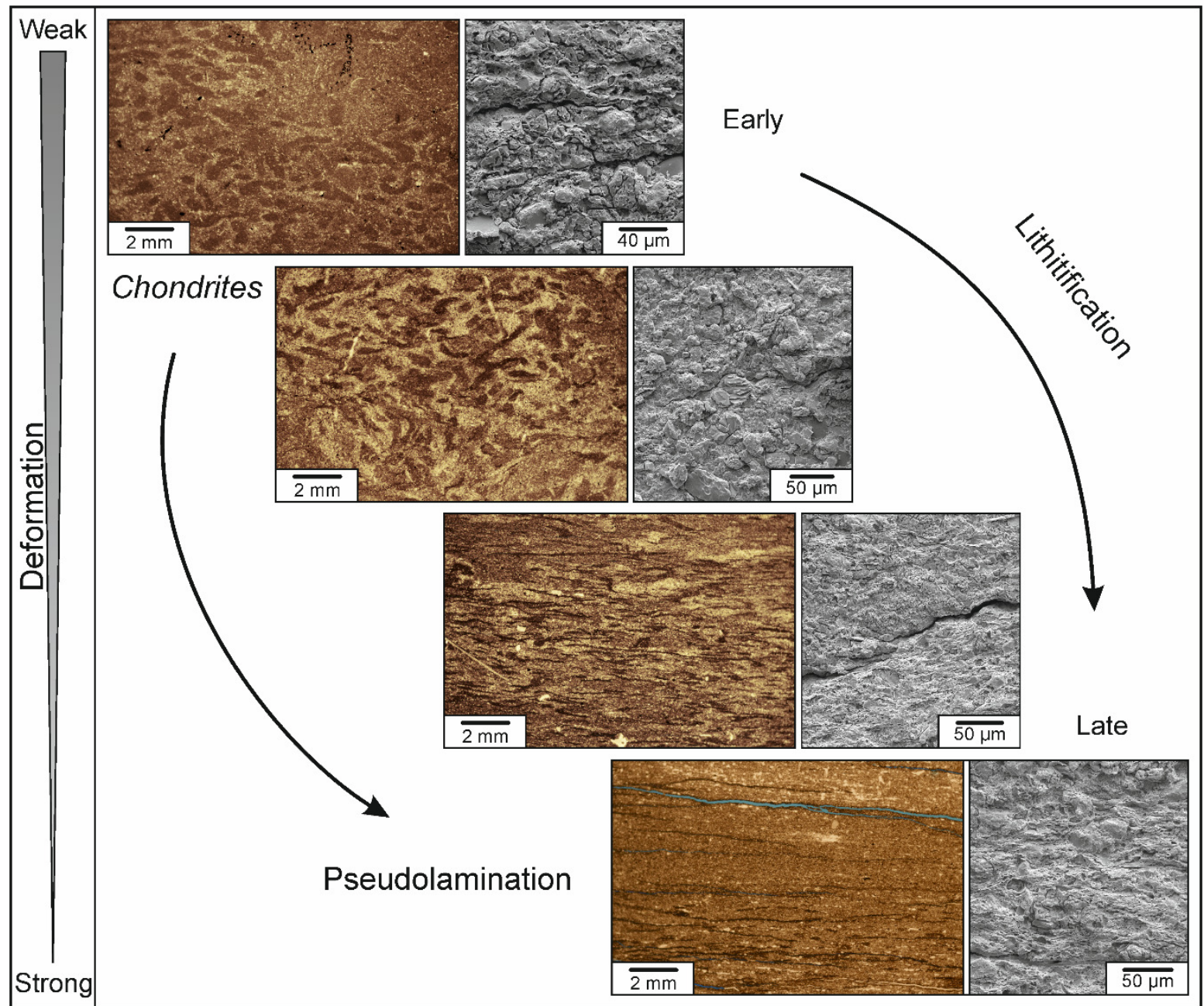

Figure 7.12: Different deformation stages of bioturbation tubes. Strongly deformed tubes cause diagenetic pseudolamination, thus affecting vertical fracture propagation. SEM analyses reveal that with increasing compaction the clay minerals surrounding the grains are more oriented.

\subsubsection{Definition of mechanical units}

A representative section to define a mechanical unit is NP2; the selected subsection comprises two well-bedded limestones (Beds D and J) and two semi-nodular limestones (Beds F and G) 
interbedded with three laminated calcareous marls (Beds E,G and I all with the same thickness; Fig. 7.11A). The succession from bed $\mathrm{D}$ to bed $\mathrm{J}$ is restricted by thick regular and laminated marls (Beds B,C,K and L; Fig. 7.11A). The unit (interbed $\mathrm{E}$ to bed $\mathrm{J}$ ) is characterised by low percentages of fracture terminations at the lithological contacts and high percentages of non-stratabound fractures within the respective beds and interbeds. Compared with the contact between well-bedded limestones and regular marls ('mechanical interface') the contact between semi-nodular limestones and laminated calcareous marls is more welded and the tensile strength across the contact is negligible ('lithological contact'; Fig. 7.11B). When lithological contacts are weak in shear, fractures can propagate along the contact more easily than into the adjacent bed or interbed (e.g. Renshaw and Pollard, 1995; Cooke and Underwood, 2001). The succession is bounded by thicker interbeds, which have greater resistance to fracture propagation, and thus could be defined as a 'mechanical buffer' (Beds B,C and K; Fig. 7.11; grey bar). When these layers are, in addition, laminated due to deformed bioturbation tubes (diagenetic pseudolamination) the vertical fracture permeability is poor (Fig. 7.12). These interbeds are probably more strongly compacted because of the previous ductile behaviour during the early burial stage.

\subsection{Conclusions and implications for reservoir permeability and exploration}

In layered rocks, fracture permeability varies considerably from layer to layer due to different stress barriers, for example, mechanical properties change between layers ('mechanical layering'). In contrast, several layers can act mechanically as a single unit ('mechanical unit') despite internal lithological changes. More than 4000 fractures in six sections with a wide range of morphological variations (ranging from limestone dominated to marl dominated) of the Blue Lias Formation (Lower Jurassic, Hettangian-Sinemurian) were investigated. Stress barriers were mapped based on vertical fracture terminations at and crossings through lithological contacts and extension through layers. The influence of diagenesis and sedimentary features based on observations from metre to micrometre scale were investigated, in order to define mechanical interfaces, buffers and units for layered rocks. The results show that stress barriers are not only related to (1) the contrast in rock properties but also to (2) the lithological contacts, (3) interbed thicknesses and (4) interbed heterogeneities. Since not all lithological contacts inhibit fracture propagation in layered rock, the term 'mechanical interface' was only used in this study for $50 \%$ of fracture terminations. Most lithological contacts promote fracture terminations $(70 \%)$ and are thus mechanical interfaces (Fig. 7.8). 
In conclusion, lithological contacts are mechanical interfaces when the contacts are nonwelded. In addition, the term 'mechanical buffers' was defined in this study for more than $50 \%$ fracture terminations at the top and bottom of beds or interbeds and less than $50 \%$ fractures propagating through beds or interbeds. These 'mechanical buffers' reveal that, usually, great thicknesses (maximum interbed thickness $=0.2 \mathrm{~m}$ ) inhibit vertical fracture propagation. Interbed heterogeneities, such as deformed bioturbation tubes (diagenetic pseudolamination), are commonly within these 'mechanical buffers' which additionally inhibit vertical fracture propagation. When multiple layers have almost the same $\mathrm{CaCO}_{3}$ content and probably also the same Young's moduli, and when the contacts are welded, these multiple layers may act mechanically as a single unit ('mechanical unit').

These interbed characteristics (e.g. lithological contacts, thickness and heterogeneities) differ within the different LMA and consequently crucially affect the vertical fracture propagation. This makes predictions of fracture networks more difficult. The characterisation and quantification of these rock heterogeneities and their effects on fracture propagation and arrest are crucial for a better prediction of fracture-associated permeability and fluid flow models. The findings assist the characterisation of naturally fractured reservoirs in outcrop analogue studies.

\section{Acknowledgments}

This study was supported by the Deutsche Forschungsgemeinschaft (DFG, grant PH 189/2-1). For further financial support we thank the International Association of Sedimentologists (IAS, postgraduate grant scheme, $2^{\text {nd }}$ session) for final SEM analyses at the Friedrich-AlexanderUniversity of Erlangen-Nürnberg. We acknowledge Sebastian Flotow (Leibniz Centre for Tropical Marine Ecology, thin section), Dr Andreas Reimer, Birgit Röring (Georg-August University of Göttingen, CNS-Analysis) and Dorothea Hause-Reitner (Georg-August University of Göttingen, SEM) for technical support. We thank Prof. Joachim Reitner (GeorgAugust University of Göttingen) and Dr Axel Munnecke (Friedrich-Alexander University of Erlangen-Nürnberg) for constructive discussions and providing devices. Dr Jan-Peter Duda is acknowledged for assistance in the field and Sebastián Oriolo is acknowledged for constructive discussions.

\section{References}

Afşar F., Westphal H., Philipp S.L. (2014) How facies and diagenesis affect fracturing of limestone beds and reservoir permeability in limestone-marl alternations. Marine and Petroleum Geology, 57, 418-432.

Aguilera R. (2000) Well test analysis of multi-layered naturally fractured reservoirs. Journal of Canadian Petroleum Technology, 39, 31-37.

Bell F.G. (2000) Engineering properties of soils and rocks. Fourth ed., Blackwell, Oxford. 
Biot M.A., Medlin W.L., Masse L. (1983) Fracture penetration through an interface. Society of Petroleum Engineers Journal, 23, 857-869.

Bloos G., Page K.N. (2002) Global stratotype section and point for base of the Sinemurian Stage (Lower Jurassic). Episodes, 25, 22-28.

Boro H., Bertotti G., Hardebol N.J. (2013) Distributed fracturing affecting isolated carbonate platforms, the Latemar platform natural laboratory (Dolomites, North Italy). Marine and Petroleum Geology, 40, 69-84.

Cooke M.L., Underwood C.A. (2001) Fracture termination and step-over at bedding interfaces due to frictional slip and interface opening. Journal of Structural Geology, 23, 223-238.

Cope J.C.W. (2006) Jurassic: the returning seas. In: Brenchley P.J., Rawson P.F. (Eds.) The Geology of England and Wales. Second ed., Journal of the Geological Society London, pp. 325-363.

Corbett K.P., Friedman M., Spang J. (1987) Fracture development and mechanical stratigraphy of Austin Chalk, Texas. American Association of Petroleum Geologists Bulletin, 71, 17-28.

Cox B.M., Sumbler M.G., Ivimey-Cook H.C. (1999) A Formational Framework for the Lower Jurassic of England and Wales (Onshore Area). British Geological Survey Research Report, $\mathrm{RR} / 99 / 01$.

Donovan D.T., Horton A., Ivimey-Cook H.C. (1979) The transgression of the Lower Lias over the northern flank of the London Platform. Journal of the Geological Society London, 136, 165-173.

Dunham R.J. (1962) Classification of carbonate rocks according to depositional texture. In: Ham W. E. (Eds.) Classification of Carbonate Rocks. American Association of Petroleum Geologists Memoir, pp. 108-121.

Einsele G, Ricken W., Seilacher A. (1991) Cycles and Events in Stratigraphy. SpringerVerlag, Berlin Heidelberg.

Erdogan F. (1972) Fracture problems in composite materials. Engineering Fracture Mechanics, 4, 811-840.

Gross M.R. (1993) The origin and spacing of cross joints: Examples from the Monterey Formation, Santa-Barbara Coastline, California. Journal of Structural Geology, 15, 737-751.

Gudmundsson A. (2011) Rock Fractures in Geological Processes. Cambridge University Press, Cambridge.

Gudmundsson A., Brenner S.L. (2001) How hydrofractures become arrested. Terra Nova, 13, 456-462.

Hallam A. (1960) A sedimentary and faunal study of the Blue Lias of Dorset and Glamorgan. Philosophical Transactions of the Royal Society B, 243, 1-44.

Hallam A. (1992) Jurassic. In: McLaren P., Duff D., Smith A.J. (Eds.) Geology of England and Wales. Geological Society of London, pp. 325-354.

Harvey T., Gray J. (2011) The Unconventional Hydrocarbon Resources of Britain's Onshore Basins - Shale Gas. London, UK: Department of Energy and Climate Change.

Helgeson D.E., Aydin A. (1991) Characteristics of joint propagation across layer interfaces in sedimentary rocks. Journal of Structural Geology, 13, 897-911.

Hobbs D.W. (1967) The formation of tension joints in sedimentary rocks: An Explanation. Geological Magazine, 104, 550-556.

Kamerling P. (1979) The geology and hydrocarbon habitat of the Bristol Channel Basin. Journal of Petroleum Geology, 2, 75-93.

Kent P.E. (1936) The formation of the hydraulic limestones of the Lower Lias. Geological Magazine, 73, 476-478. 
Laubach S.E., Olson J.E., Gross M.R. (2009) Mechanical and fracture stratigraphy. American Association of Petroleum Geologists Bulletin, 93, 1413-1426.

Mandl G. (2005) Rock joints: The mechanical genesis. Springer, Berlin.

Narr W., Suppe J. (1991) Joint spacing in sedimentary rocks. Journal of Structural Geology, 13, 1037-1048.

Nelson R.A. (1985) Geologic Analysis of Naturally Fractured Reservoirs. First ed., Gulf Publishing Company, Houston, Texas.

Noble J.P.A., Howells K.D.M. (1974) Early marine lithification of the nodular limestones in the Silurian of New Brunswick. Sedimentology, 21, 597-609.

Odling N.E., Gillespie P., Bourgine B., Castaing C., Chilés J.-P., Christensen N.P., Fillion E., Genter A., Olsen C., Thrane L., Trice R., Aarseth E., Walsh J.J., Watterson J. (1999) Variations in fracture system geometry and their implications for fluid flow in fractured hydrocarbon reservoirs. Petroleum Geoscience, 5, 373-384.

Philipp S.L., Afşar F., Gudmundsson A. (2013) Effects of mechanical layering on hydrofracture emplacement and fluid transport in reservoirs. Frontiers of Earth Science, 1, 1-19.

Pollard D.D., Aydin A. (1988) Progress in understanding jointing over the past century. Geological Society of America Bulletin, 100, 1181-1204.

Price N.J. (1966) Fault and Joint Development in Brittle and Semi-Brittle Rock. Pergamon Press, London.

Renshaw C.E., Pollard D.D. (1995) An experimentally verified criterion for propagation across unbounded frictional interfaces in brittle, linear elastic materials. International Journal of Rock Mechanics and Mining, 32, 237-249.

Ricken W. (1986) Diagenetic bedding: A model for marl-limestone alternations. In: Bhattacharji S., Friedman G.M., Neugebauer H.J., Seilacher A. (Eds.) Lecture Notes in Earth Sciences. Springer-Verlag, Berlin Heidelberg, pp.1-210.

Rijken P., Cooke M.L. (2001) Role of shale thickness on vertical connectivity of fractures: Application of crack-bridging theory to the Austin Chalk, Texas. Tectonophysics, 337, 117-133.

Sheppard T.H., Houghton R.D., Swan A.R.H. (2006) Bedding and pseudo-bedding in the early Jurassic of Glamorgan: Deposition and diagenesis of the Blue Lias in South Wales. Proceedings of the Geologists' Association, 117, 249-264.

Stauffer D., Aharônî A. (1994) Introduction to Percolation Theory. Rev. second ed., Taylor \& Francis Ltd, London.

Stewart S.A., Ruffell A.H., Harvey M.J. (1997) Relationship between basement-linked and gravity-driven fault systems in the UKCS salt basins. Marine and Petroleum Geology, 14, 581-604.

Sujkowski Z.L. (1958) Diagenesis. Bulletin of the American Association of Petroleum Geologists, 42, 2692-2717.

Tappin D.R., Chadwick R.A., Jackson A.A., Wingfield R.T.R., Smith N.J.P. (1994) The Geology of Cardigan Bay and the Bristol Channel, United Kingdom Offshore Regional Report. British Geological Survey, London.

Teufel L.W., Clark J.A. (1984) Hydraulic fracture propagation in layered rock - experimental studies of fracture containment. Society of Petroleum Engineers Journal, 24, 19-32.

van Eekelen H.A.M. (1982) Hydraulic fracture geometry - fracture containment in layered formations. Society of Petroleum Engineers Journal, 22, 341-349.

van Hoorn B. (1987) The South Celtic Sea/Bristol Channel Basin: Origin, deformation and inversion history. Tectonophysics, 137, 309-334.

Weedon G.P. (1986) Hemipelagic shelf sedimentation and climatic cycles: The basal Jurassic (Blue Lias) of South Britain. Earth and Planetary Science Letters, 76, 321-335. 
Westphal H., Head M.J., Munnecke A. (2000) Differential diagenesis of rhythmic limestone alternations supported by palynological evidence. Journal of Sedimentary Research, 70, 715-725.

Whittaker A., Green G.W. (1983) Geology of the Country around Weston-super-Mare. Geological Survey of Great Britain, Institute of Geological Sciences, Her Majesty's Stationary Office, London.

Wilson D., Davies J.R., Fletcher C.J.N., Smith M. (1990) Geology of the South Wales Coalfield, Part VI, the Country Around Bridgend. Second ed., British Geological Survey, London.

Wobber F.J. (1968) Microsedimentary analysis of Lias in South Wales. Sedimentary Geology, 2, 13-49.

Woodcock N., Strachan R. (2002) Geological History of Britain and Ireland. Blackwell Publishing. 


\section{Appendix}

\begin{tabular}{|c|c|c|c|c|c|c|c|c|c|c|c|c|c|c|}
\hline \multirow{2}{*}{ Section } & \multirow{2}{*}{$\begin{array}{l}\text { Fracture } \\
\text { trace }\end{array}$} & \multicolumn{13}{|c|}{ Beds/Interbeds } \\
\hline & & A & B & C & D & $E$ & $\mathrm{~F}$ & G & $\mathrm{H}$ & 1 & $\mathrm{~J}$ & $\mathrm{~K}$ & L & $M$ \\
\hline \multirow{7}{*}{ NP1 } & 1 & 2 & 23 & 4 & 27 & 0 & 37 & 6 & 35 & 14 & 24 & 0 & 33 & 1 \\
\hline & 2 & 0 & 15 & 9 & 10 & 0 & 33 & 13 & 49 & 9 & 31 & 0 & 22 & 3 \\
\hline & 3 & 32 & 8 & 39 & 44 & 72 & 29 & 91 & 78 & 71 & 69 & 64 & 13 & 65 \\
\hline & 4 & 7 & 9 & 46 & 29 & 16 & 25 & 73 & 50 & 68 & 45 & 71 & 9 & 76 \\
\hline & 5 & 0 & 23 & 2 & 1 & 4 & 38 & 11 & 15 & 6 & 16 & 0 & 17 & 5 \\
\hline & 6 & 0 & 8 & 7 & 17 & 0 & 17 & 12 & 22 & 15 & 14 & 0 & 9 & 1 \\
\hline & 7 & 31 & 1 & 9 & 5 & 33 & 4 & 9 & 20 & 4 & 16 & 48 & 1 & 18 \\
\hline \multirow{7}{*}{ NP2 } & 1 & 8 & 29 & 21 & 20 & 0 & 1 & 0 & 4 & 2 & 3 & 4 & 2 & 0 \\
\hline & 2 & 2 & 0 & 0 & 8 & 8 & 22 & 13 & 17 & 15 & 6 & 2 & 0 & 5 \\
\hline & 3 & 7 & 3 & 10 & 9 & 17 & 4 & 7 & 2 & 1 & 6 & 2 & 15 & 3 \\
\hline & 4 & 3 & 2 & 9 & 3 & 11 & 2 & 16 & 5 & 4 & 9 & 4 & 10 & 8 \\
\hline & 5 & 0 & 6 & 10 & 5 & 15 & 7 & 4 & 6 & 6 & 4 & 3 & 11 & 2 \\
\hline & 6 & 6 & 2 & 5 & 3 & 2 & 11 & 7 & 1 & 5 & 9 & 8 & 1 & 14 \\
\hline & 7 & 3 & 1 & 0 & 0 & 0 & 0 & 0 & 0 & 0 & 0 & 1 & 3 & 0 \\
\hline \multirow{7}{*}{ NP3 } & 1 & 6 & 14 & 2 & 7 & 0 & 4 & 7 & 11 & 6 & 8 & 0 & 11 & - \\
\hline & 2 & 0 & 45 & 2 & 18 & 0 & 14 & 4 & 15 & 6 & 17 & 0 & 26 & - \\
\hline & 3 & 36 & 3 & 35 & 0 & 35 & 19 & 20 & 4 & 15 & 2 & 30 & 0 & - \\
\hline & 4 & 2 & 2 & 49 & 2 & 28 & 9 & 24 & 1 & 28 & 3 & 50 & 1 & - \\
\hline & 5 & 21 & 7 & 2 & 10 & 0 & 16 & 3 & 22 & 11 & 30 & 0 & 23 & - \\
\hline & 6 & 0 & 7 & 3 & 17 & 0 & 8 & 25 & 8 & 9 & 10 & 1 & 0 & - \\
\hline & 7 & 2 & 0 & 15 & 0 & 27 & 0 & 3 & 0 & 3 & 0 & 2 & 0 & - \\
\hline \multirow{7}{*}{ KI1 } & 1 & 0 & 14 & 4 & 1 & 8 & 21 & 3 & 12 & 18 & 23 & - & - & - \\
\hline & 2 & 0 & 10 & 1 & 0 & 8 & 1 & 0 & 0 & 10 & 4 & - & - & - \\
\hline & 3 & 25 & 0 & 37 & 33 & 8 & 10 & 27 & 27 & 1 & 8 & - & - & - \\
\hline & 4 & 5 & 3 & 44 & 14 & 8 & 24 & 14 & 13 & 1 & 28 & - & - & - \\
\hline & 5 & 0 & 14 & 2 & 2 & 11 & 3 & 1 & 8 & 3 & 3 & - & - & - \\
\hline & 6 & 0 & 2 & 0 & 3 & 7 & 7 & 0 & 2 & 4 & 4 & - & - & - \\
\hline & 7 & 32 & 0 & 44 & 18 & 4 & 5 & 18 & 11 & 1 & 5 & - & - & - \\
\hline \multirow{7}{*}{ LIL2 } & 1 & 23 & 7 & 13 & 21 & 20 & 28 & 6 & 11 & 17 & 27 & - & - & - \\
\hline & 2 & 28 & 4 & 23 & 18 & 21 & 0 & 0 & 32 & 8 & 15 & - & - & - \\
\hline & 3 & 9 & 25 & 8 & 27 & 17 & 5 & 48 & 11 & 30 & 4 & - & - & - \\
\hline & 4 & 8 & 39 & 9 & 14 & 16 & 13 & 18 & 4 & 30 & 8 & - & - & - \\
\hline & 5 & 21 & 22 & 11 & 18 & 9 & 0 & 5 & 21 & 22 & 18 & - & - & - \\
\hline & 6 & 10 & 17 & 14 & 10 & 21 & 30 & 0 & 6 & 23 & 26 & - & - & - \\
\hline & 7 & 2 & 1 & 2 & 3 & 27 & 3 & 41 & 0 & 2 & 0 & - & - & - \\
\hline \multirow{7}{*}{ KN3 } & 1 & 3 & 34 & 3 & 26 & 9 & 39 & - & - & - & - & - & - & - \\
\hline & 2 & 0 & 28 & 6 & 47 & 11 & 18 & - & - & - & - & - & - & - \\
\hline & 3 & 67 & 12 & 58 & 4 & 37 & 18 & - & - & - & - & - & - & - \\
\hline & 4 & 31 & 5 & 59 & 5 & 54 & 9 & - & - & - & - & - & - & - \\
\hline & 5 & 1 & 26 & 12 & 20 & 8 & 7 & - & - & - & - & - & - & - \\
\hline & 6 & 0 & 14 & 2 & 11 & 15 & 25 & - & - & - & - & - & - & - \\
\hline & 7 & 41 & 0 & 16 & 0 & 7 & 1 & - & - & - & - & - & - & - \\
\hline
\end{tabular}

Table 7.1: Summary of all seven fracture traces in each bed of all six sections. 1) fractures cross through both lithological contacts; 2) and 3) fractures cross just one lithological contact either at the top or at the bottom, respectively; 4) fractures terminate at both lithological contacts; 5) and 6) fractures terminate at one lithological contact but do not cross through the entire bed or interbed; 7) fractures terminate within the bed or interbed. All interbeds are marked in bold. 


\begin{tabular}{|c|c|c|c|c|c|c|c|c|c|c|c|c|c|c|}
\hline \multirow{2}{*}{ Section } & & \multicolumn{13}{|c|}{ Beds/Interbeds } \\
\hline & & A & B & $\mathrm{C}$ & $\mathrm{D}$ & $E$ & $\mathrm{~F}$ & G & $\mathrm{H}$ & 1 & J & $\mathrm{K}$ & L & M \\
\hline \multirow{5}{*}{ NP1 } & Lithology & LM & SNL & CM & WBL & LM & WBL & $\mathrm{CM}$ & WBL & $\mathrm{CM}$ & WBL & RM & SNL & RM \\
\hline & Bed thickness $[\mathrm{cm}]$ & 15 & 10 & 7 & 18 & 13 & 11 & 6 & 11 & 5 & 17 & 20 & 8 & 13 \\
\hline & $\mathrm{CaCO}_{3}[\mathrm{wt} \%]$ & 25 & 86 & 59 & 83 & 31 & 85 & 64 & 81 & 52 & 78 & 46 & 74 & 56 \\
\hline & $\mathrm{C}_{\text {org }}[\mathrm{wt} \%]$ & 1.92 & 0.25 & 0.64 & 0.24 & 1.63 & 0.25 & 0.50 & 0.29 & 0.60 & 0.32 & 0.99 & 0.51 & 0.83 \\
\hline & Rock hardness (RE) & 198 & 590 & 338 & 551 & 219 & 544 & 289 & 548 & 216 & 537 & 264 & 483 & 237 \\
\hline \multirow{5}{*}{ NP2 } & Lithology & WBL & RM & LM & WBL & LCM & SNL & LCM & SNL & LCM & WBL & RM & LM & WBL \\
\hline & Bed thickness $[\mathrm{cm}]$ & 49 & 5 & 6 & 27 & 5 & 6 & 5 & 11 & 5 & 26 & 5 & 15 & 37 \\
\hline & $\mathrm{CaCO}_{3}[\mathrm{wt} \%]$ & 50 & 27 & 29 & 89 & 51 & 74 & 48 & 82 & 44 & 89 & 41 & 56 & 72 \\
\hline & $\mathrm{C}_{\text {org }}[w t \%]$ & 0.54 & 0.73 & 1.10 & 0.23 & 0.62 & 0.24 & 0.61 & 0.21 & 0.56 & 0.21 & 1.07 & 2.15 & 0.32 \\
\hline & Rock hardness (RE) & 617 & 268 & 361 & 631 & 322 & 549 & 307 & 634 & 303 & 611 & 279 & 338 & 629 \\
\hline \multirow{5}{*}{ NP3 } & Lithology & RM & SNL & RM & SNL & RM & WBL & $\mathrm{CM}$ & SNL & $\mathrm{CM}$ & SNL & RM & SNL & - \\
\hline & Bed thickness $[\mathrm{cm}]$ & 7 & 6 & 16 & 16 & 23 & 24 & 7 & 10 & 8 & 12 & 13 & 11 & 一 \\
\hline & $\mathrm{CaCO}_{3}[\mathrm{wt} \%]$ & 41 & 82 & 51 & 84 & 33 & 79 & 59 & 86 & 65 & 92 & 33 & 81 & - \\
\hline & $\mathrm{C}_{\text {org }}[w t \%]$ & 1.03 & 0.27 & 0.46 & 0.20 & 0.74 & 0.33 & 0.55 & 0.47 & 0.37 & 0.18 & 0.96 & 0.28 & - \\
\hline & Rock hardness (RE) & 196 & 508 & 205 & 587 & 196 & 600 & 259 & 592 & 243 & 597 & 205 & 599 & - \\
\hline \multirow{5}{*}{ KI1 } & Lithology & RM & SNL & LCM & LM & SNL & CM & LM & $\mathrm{CM}$ & WBL & RM & - & - & - \\
\hline & Bed thickness $[\mathrm{cm}]$ & 28 & 14 & 23 & 29 & 16 & 7 & 43 & 11 & 12 & 5 & - & 一 & - \\
\hline & $\mathrm{CaCO}_{3}[\mathrm{wt} \%]$ & 42 & 86 & 57 & 26 & 78 & 55 & 36 & 50 & 82 & 64 & - & - & - \\
\hline & $\mathrm{C}_{\text {org }}[\mathrm{wt} \%]$ & 0.72 & 0.24 & 0.90 & 7.12 & 0.73 & 0.57 & 15.73 & 2.47 & 0.48 & 0.79 & - & - & - \\
\hline & Rock hardness (RE) & 306 & 590 & 323 & 266 & 534 & 283 & 302 & 292 & 565 & 273 & - & - & - \\
\hline \multirow{5}{*}{ LIL2 } & Lithology & WBL & LCM & WBL & $\mathrm{CM}$ & WBL & $\mathrm{CM}$ & LM & WBL & $\mathrm{CM}$ & SNL & - & - & - \\
\hline & Bed thickness $[\mathrm{cm}]$ & 18 & 9 & 21 & 6 & 19 & 5 & 27 & 13 & 7 & 11 & - & - & - \\
\hline & $\mathrm{CaCO}_{3}[\mathrm{wt} \%]$ & 82 & 52 & 84 & 59 & 77 & 48 & 36 & 82 & 52 & 84 & - & - & - \\
\hline & $C_{\text {org }}[w t \%]$ & 0.32 & 0.73 & 0.36 & 0.70 & 0.46 & 0.87 & 3.34 & 0.27 & 1.01 & 0.28 & - & - & - \\
\hline & Rock hardness (RE) & 554 & 345 & 589 & 352 & 584 & 314 & 298 & 580 & 320 & 571 & - & - & 一 \\
\hline \multirow{5}{*}{ KN3 } & Lithology & LM & WBL & LM & SNL & $\mathrm{CM}$ & WBL & - & - & - & - & - & - & - \\
\hline & Bed thickness $[\mathrm{cm}]$ & 36 & 16 & 18 & 11 & 11 & 21 & - & - & - & - & - & - & - \\
\hline & $\mathrm{CaCO}_{3}[\mathrm{wt} \%]$ & 40 & 83 & 47 & 86 & 47 & 80 & - & - & - & 一 & - & - & - \\
\hline & $\mathrm{C}_{\text {org }}[w t \%]$ & 0.95 & 0.24 & 1.58 & 0.26 & 0.91 & 0.33 & - & - & - & - & - & - & - \\
\hline & Rock hardness (RE) & 288 & 598 & 304 & 582 & 307 & 612 & - & - & - & - & - & - & - \\
\hline
\end{tabular}

Table 7.2: Summary of lithologies $(\mathrm{WBL}=$ well-bedded limestones, $\mathrm{SNL}=$ semi-nodular limestones, $\mathrm{CM}=$ calcareous marls, $\mathrm{LCM}=$ laminated calcareous marls, $\mathrm{LM}=$ laminated marls, $\mathrm{RM}=$ regular marls), average bed thickness $[\mathrm{cm}], \mathrm{CaCO}_{3} / \mathrm{C}_{\text {org }}$ content $[\mathrm{wt} \%]$ and rock hardness values (RE) of each bed collected in six sections. All interbeds are marked in bold. 


\title{
-Chapter 8-
}

\section{Assessing the influence of diagenesis in limestone-marl alternations on metre to micrometre scale and the effects of diagenetic features on fracture propagation}

\author{
Filiz Afşar ${ }^{\text {a,*, Sonja L. Philipp a }}{ }^{\text {, Hildegard Westphal }}{ }^{\text {b, c }}$ \\ ${ }^{a}$ University of Göttingen, Geoscience Centre (GZG), Structural Geology and Geodynamics, Goldschmidtstraße \\ 3, D-37077 Göttingen, Germany \\ ${ }^{b}$ Leibniz Centre for Tropical Marine Ecology GmbH (ZMT), Biogeochemistry and Geology, Geoecology and \\ Carbonate Sedimentology, Fahrenheitstraße 6, D-28359 Bremen, Germany \\ ${ }^{c}$ University of Bremen, Department of Geosciences, Klagenfurter Straße, D-28359 Bremen, Germany
}

*Correspondence: filiz.afsar@geo.uni-goettingen.de

Manuscript in preparation

\begin{abstract}
The diagenesis of three sections in close vicinity $(<500 \mathrm{~m}$ linear distance) and several metres thick subsections of limestone-marl alternations of the Blue Lias Formation (Hettangian-Sinemurian) in Wales (UK) was studied. The main aim of this study is to assess diagenetic features from metre to micrometre scales (conducted by field observations, thin section petrography, SEM analyses) in limestone-marl alternation. Furthermore, the effects of these diagenetic features on the vertical fracture propagation in metre scale is discussed, in order to define a unit of several layers which acts mechanically as one single unit ('mechanical unit'). Mechanical units improve the prediction of fracture-associated permeability in heterogeneous reservoirs. The stratigraphic offset between the three studied subsections is negligible, as the throw of intersecting faults range only between 1.9 to $2.6 \mathrm{~m}$. Despite of the close vicinity and relative contemporaneous time of deposition, all three subsections are characterised by different major sedimentological and diagenetic features, ranging from early lithification (subsection NP1) to physical compaction due to differential compaction processes (subsection NP2) or overburden pressure (subsection NP3). However, problematically in case of all subsections no evidence for compaction was observed on the micrometre scale. Not only the sedimentological and diagenetic features are different of all three subsections, but also the quantity of vertical fracture extension (e.g. percentages of stratabound versus non-stratabound fractures) and fractures terminating at or crossings through lithological contacts are different as well. It appears that diagenetic features observed on a metre scale (conducted field observations) have an impact on the fracture propagation over several layers, while observations on micrometre scale (SEM analyses) are negligible in both limestones and marls. Because of these heterogeneities the prediction of fracture network connectivity in such successions is difficult. Therefore in this study it is crucial to define mechanical units which promote the fracture propagation despite of these heterogeneities. Lithological contacts in differential diagenetic influenced successions (e.g. subsection NP2) are more gradual if additionally the contrast of $\mathrm{CaCO}_{3}$ contents between limestones and marls is low, the succession can be defined as a mechanical unit.
\end{abstract}




\subsection{Introduction}

The origin of limestone-marl alternations (LMA) of the Blue Lias Formation (Hettangian-Sinemurian) in Wales (UK) has been extensively studied (e.g. Hallam, 1960; Weedon, 1986; Sheppard et al., 2006). The problem of distinguishing whether a LMA is solely sedimentary in origin (i.e. primary lithological differences due to sediment change) or is exclusively formed by differential diagenesis (i.e. the secondary formation of limestones and marls out of relatively homogenous precursor sediment) is a great challenge (Westphal et al., 2008). This is generally due to the fact that there are no clear boundaries between these end-member models of LMA. Furthermore, these models are not mutually exclusive as every primary LMA is modified by differential diagenesis (Westphal et al., 2008). Most authors agree that the alternation of the Blue Lias Formation is primary in origin but the role of diagenesis has been subject of a long-standing controversy (e.g. Hallam, 1960; Weedon, 1986; Sheppard et al., 2006; Bloos and Page, 2002). Nevertheless, a detailed study concerning the influence of diagenesis on metre to micrometre scales and additionally the effects of these diagenetic features on the vertical fracture propagation has as yet not been undertaken. Diagenetic features of these alternations have been evaluated in three subsections (NP1-NP3) in close vicinity based on field observations and thin section analyses (Afşar et al., 2014; see chapter 2 for details). It has also been shown that these diagenetic features in LMA of the Blue Lias Formation have a striking impact on the fracture propagation (Afşar et al., 2014; see chapter 6 for details).

Within layered succession such this LMA, various sedimentological features (e.g. sedimentary layering or diagenetic bedding) lead to contrasting rock properties ('mechanical layering') which significantly control the fracture distribution and fracture-associated permeability (Afşar et al., 2014; see chapter 6 for details). Problematically, both of the latter can vary considerably parallel and perpendicular to the bedding. Wide-ranging fracture systems can comprise, stratabound (i.e. fractures confined to single layers) and nonstratabound fractures (i.e. fractures extended through more layers) (cf. Odling et al., 1999; Philipp et al., 2013; see chapter 9 for details). Additionally, these two fracture system types may even change on a metre scale. This is problematical with regard to the prediction of the horizontal fracture-associated permeability in heterogeneous subsurface reservoirs, which is in turn important to generate fluid flow models. Despite of heterogeneities in rocks, due to layering, several layers can mechanically act as one single unit ('mechanical units'; Afşar et al., subm.; see chapter 7 for details). Therefore the sedimentology and diagenesis of the 
successions has to be studied in detail in order to understand the effect of rock heterogeneities on fracture patterns and to define such mechanical units in LMA (Afşar et al., 2014; Afşar et al., subm.; see chapter 6 und 7 for details).

The main aim of this study is to assess diagenetic features from metre to micrometre scales in LMA, therefore previous investigations were extended with further analyses in micrometre scales with scanning electron microscopy. Additionally, the effect of diagenetic features in metre scale on the vertical fracture propagation was discussed, in order to define a mechanical unit.

\subsection{Methods}

The study area is situated on the northern margin of the Bristol Channel in South Wales close to Nash Point (Fig. 8.1). The subsections NP1 and NP3 consist of three limestone beds and two marl layers while the subsection NP2 consists of four limestone beds and three marl layers. The limestone beds can be classified based on the nodularity of their bedding planes, with semi-nodular limestones (i.e. wavy surface at the top and/or at the base) and well-bedded limestones (i.e. relatively planar surfaces). In case of the marl layers calcareous, laminated calcareous, laminated and regular marls can be distinguished.

SEM analyses were additionally conducted in this study in order to investigate diagenetic features on a micrometre scale, with special emphasis on chemical processes (i.e. evidences for solution, compaction etc.). 16 samples were etched for three minutes (limestones) and five minutes (marls) with $5 \%$ ethylenediaminetetraacetic acid (EDTA), thoroughly cleaned with distilled water and dried for several days. The samples were subsequently spattered with Gold-palladium and examined with a SEM (TESCAN Vegallxmu and ZEISS LEO 1530 Gemini). Additionally, an energy-dispersive X-ray spectrometer (EDX) Oxford Inca coupled to the SEM was used for elemental analyses.

The orientations, throws and spatial relationships of major faults between the three subsections were measured in order to estimate the stratigraphical offset between the subsections. Furthermore, 2242 fractures were measured using a modified scan-line method (Afşar et al., 2014; see chapter 6 for details). Respective data include numbers of stratabound and non-stratabound fractures in each, limestone (referred to as 'limestone beds' in the following) and marl (referred to as 'marl interbeds' in the following) (Afşar et al., 2014; see chapter 6 for details), as well as, numbers of fractures terminating at or crossings through lithological contacts (Afşar et al., subm.; see chapter 7 for details). 


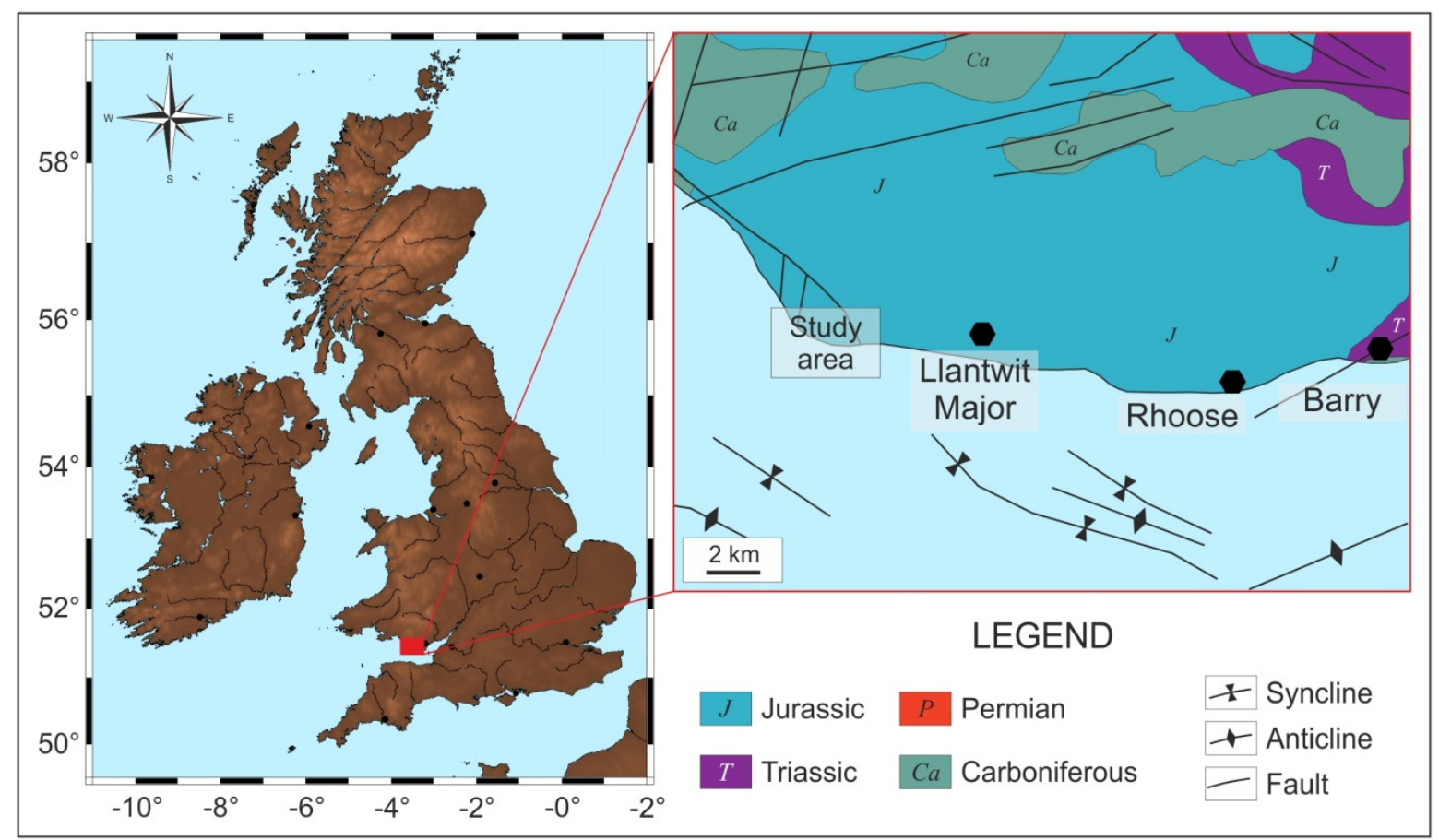

Figure 8.1: Location and geology of the study area in Wales (UK; geological map modified after Rawnsley et al., 1998).

\subsection{Results and discussion}

\subsubsection{The influence of diagenesis on the limestone-marl alternations}

Some authors e.g. propose that the variations in the clay- to carbonate-mud ratio reflect cyclic fluctuations in bottom-water oxygenation (e.g. Hallam, 1960; Weedon, 1986). The nodular structures in this area were generated by segregation of $\mathrm{CaCO}_{3}$ during early diagenesis (Hallam, 1960). Sheppard et al. (2006) interpreted the limestone/marl-contacts in LMA of the Blue Lias Formation in Wales as primary sedimentary bedding planes, while they interpret the marl/limestone-contacts as pseudo-bedding planes that originated from the diagenetic differentiation of original lime mud (Fig. 8.2). The interpretation that limestone/marl-contacts represent primary sedimentary bedding planes is mainly based on observed hardgrounds with encrusting macrofossil assemblages and trace fossils at the surface of the limestones, indicating sedimentation breaks (i.e. omission surfaces; Sheppard et al., 2006; Flügel, 2010; Fig. 8.3). A detailed study concerning the influence of diagenesis on metre to micrometre scales (i.e. field observations, thin section and SEM analyses) has as yet not been undertaken. 


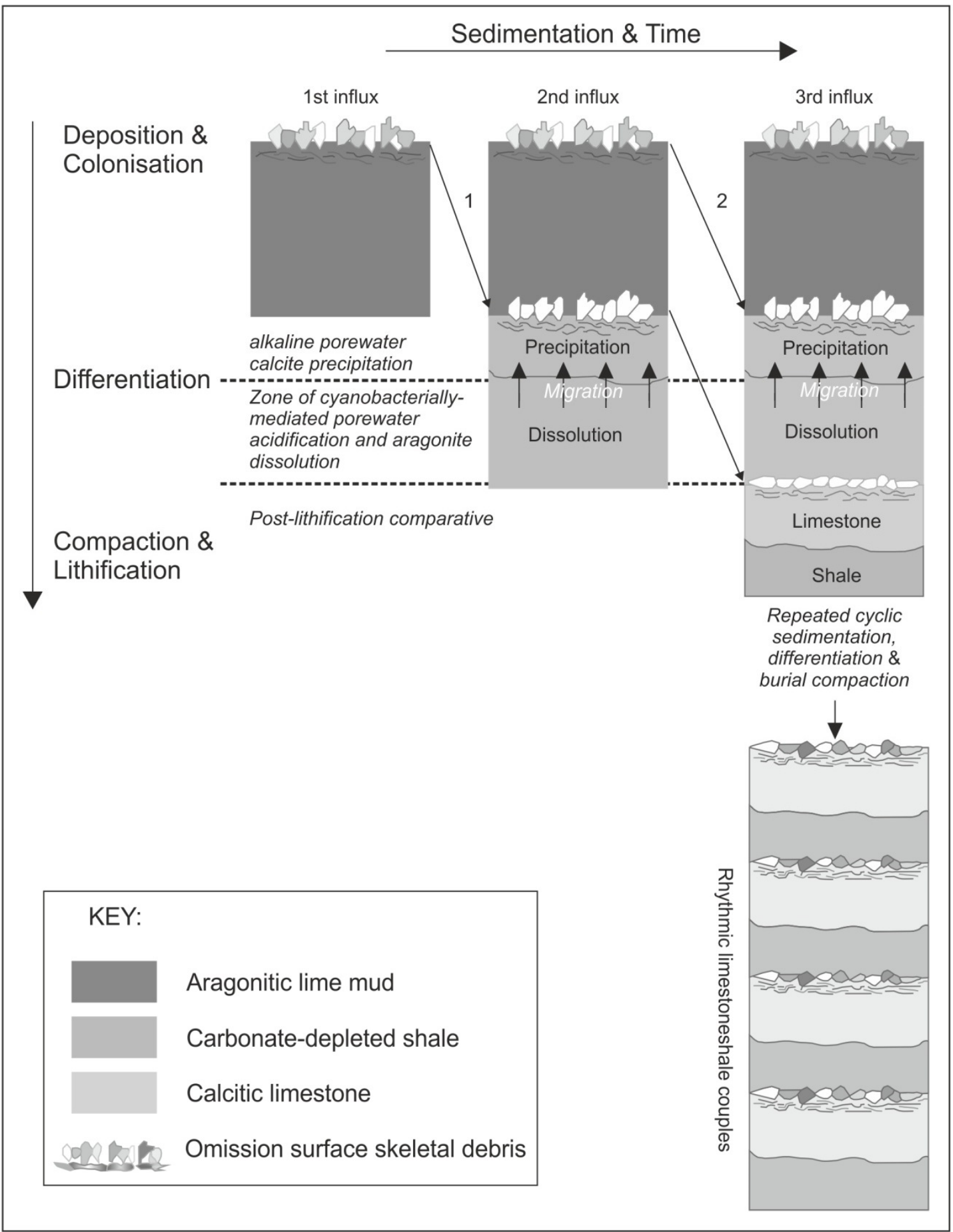

Figure 8.2: Depositional and diagenetic model for the Blue Lias Formation after Sheppard et al. (2006). In this model, based on observed omission surfaces with skeletal debris, the limestone/marl-contacts are interpreted as primary sedimentary bedding planes. In contrast, marl/limestone-contacts are interpreted as pseudo-bedding planes that originated from the diagenetic differentiation of original lime mud (Fig. modified after Sheppard et al., 2006). 
All investigated subsections are generally poor in fossils, although a few macrofossils (e.g. ammonites, gastropods) locally occur in some beds. In addition, several types of trace fossils including Chondrites and Thalassinoides were locally observed on bedding surfaces. Various microfossils including bivalves, ostracods, benthic foraminifers and radiolarians were observed on etched rock surfaces by means of SEM (Fig. 8.4).
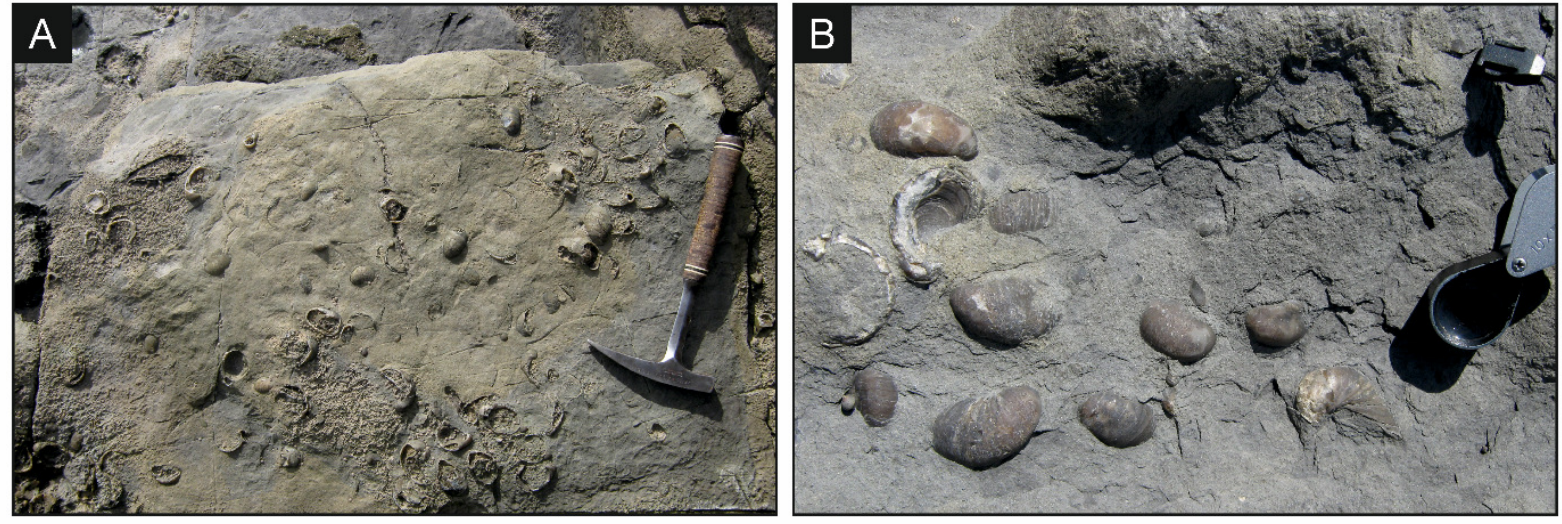

Figure 8.3: Example of putative omission surfaces characterised by abundant macrofossils. A) Planolites biofacies (hammer as scale); B) Gryphaea biofacies (lense as scale).
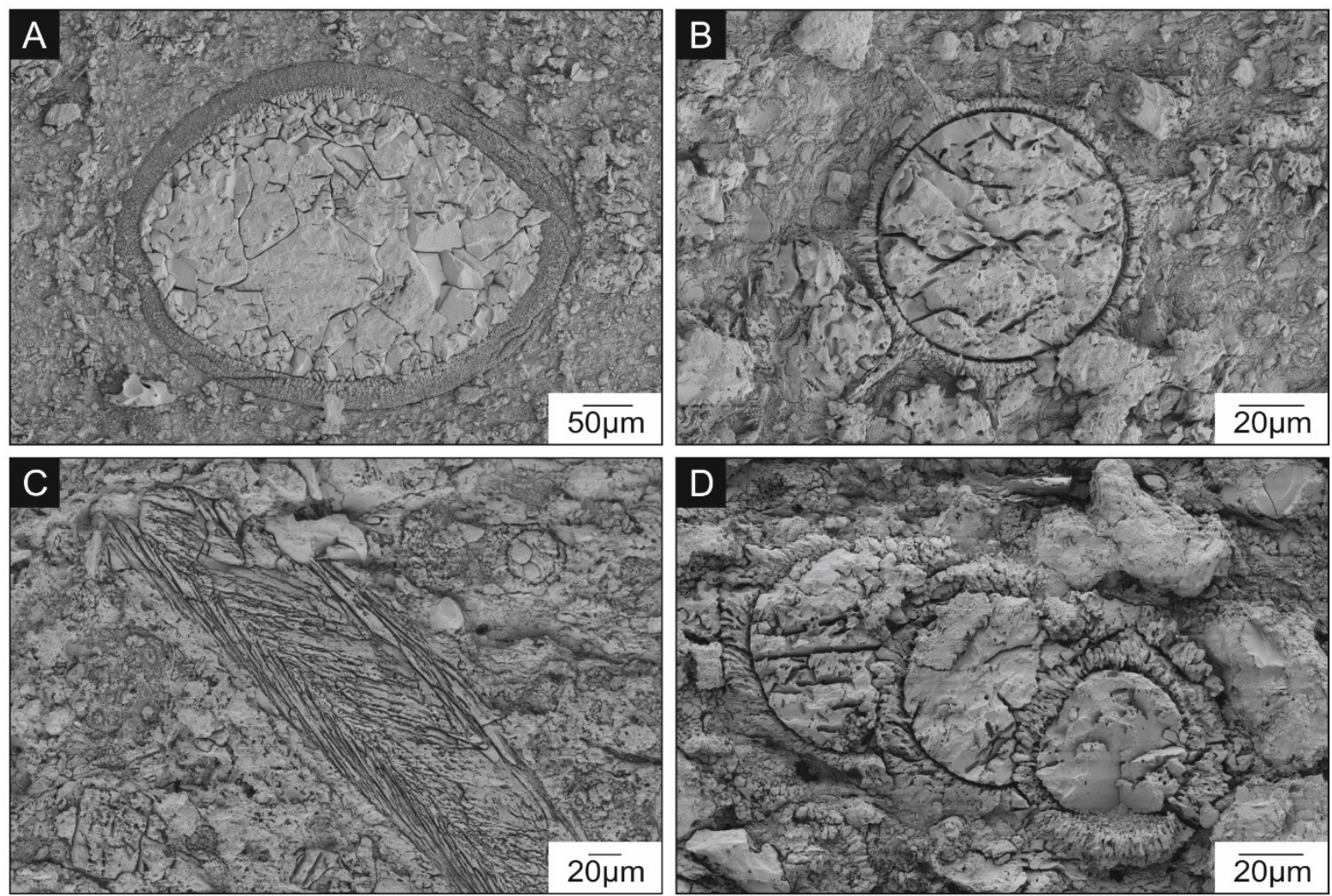

Figure 8.4: SEM photographs of microfossils in the Blue Lias Formation. A) Ostracod; B) Radiolarian; C) Bivalve fragment with distinct crossed-lamellar microstructure; D) Uniserial foraminifer. 
At the same time, neither faecal pellets nor coccolithophorids or other primary producers (e.g. dinoflagellates, diatoms) were observed which commonly are assumed as source of the carbonate mud (Weedon, 1986). The limestone beds in subsection NP1 comprise relatively planar surfaces (well-bedded limestones; beds F,H,J; Fig. 8.5A) in which neither body- nor trace fossils are deformed (Afşar et al., 2014; see chapter 6 for details). Thin section petrography revealed no signs of deformation (e.g. clay minerals oriented around microfossils) within the calcareous marls (interbeds G and I) but slight deformation in the thicker regular marls (interbeds E and K; Fig. 8.5B). Scanning electron microscopy exhibited a generally high content of clay minerals in the restricted thicker regular marl (interbeds $\mathrm{K}$; Fig. 8.5C) and clay minerals enclosed by blocky calcite spar in the well-bedded limestone (bed H; Fig. 8.5).

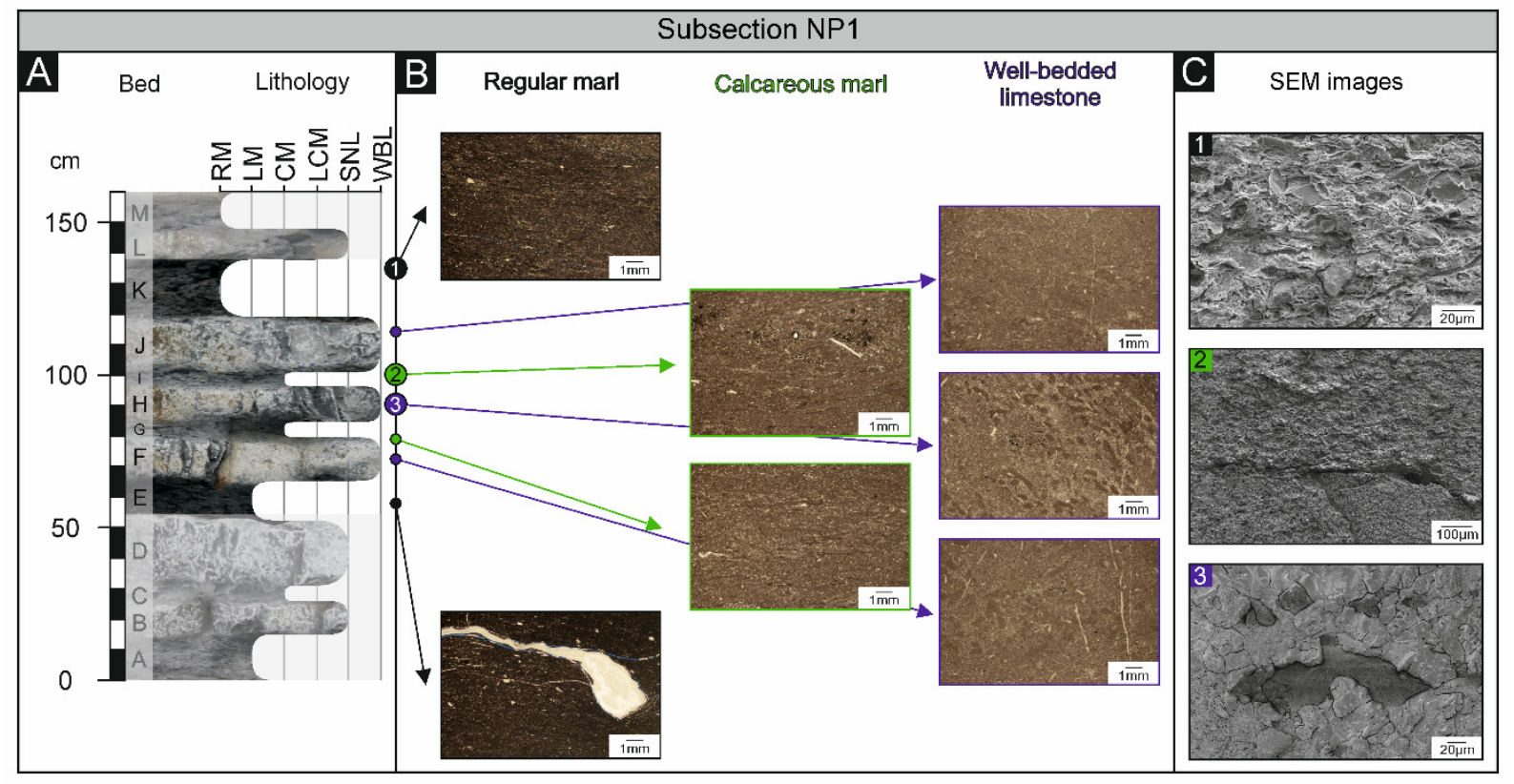

Figure 8.5: Diagenetic features in subsection NP1. A) Sedimentological subsection with six different lithologies $(\mathrm{WBL}=$ well-bedded limestones, $\mathrm{SNL}=$ semi-nodular limestones, $\mathrm{CM}=$ calcareous marls, $\mathrm{LCM}=$ laminated calcareous marls, $\mathrm{RM}=$ regular marls, $\mathrm{LM}=$ laminated marls); B) Thin section of each limestone bed and marl interbed within the subsection; C) Selected SEM images from marl interbed K (1) and I (2) and limestone bed H (3).

The planar surfaces as well as the undeformed body- and trace fossils in subsection NP1 indicate a very early lithification (Afşar et al., 2014; see chapter 6 for details). The limestone beds in subsection NP2 comprise planar surfaces (well-bedded limestones; beds D and J; Fig. 8.6A) and beds with wavy surfaces (semi-nodular limestones; beds $\mathrm{F}$ and $\mathrm{H}$; Fig. 8.6A). The laminated calcareous marl interbed I pinch out laterally and the transition from limestone to 


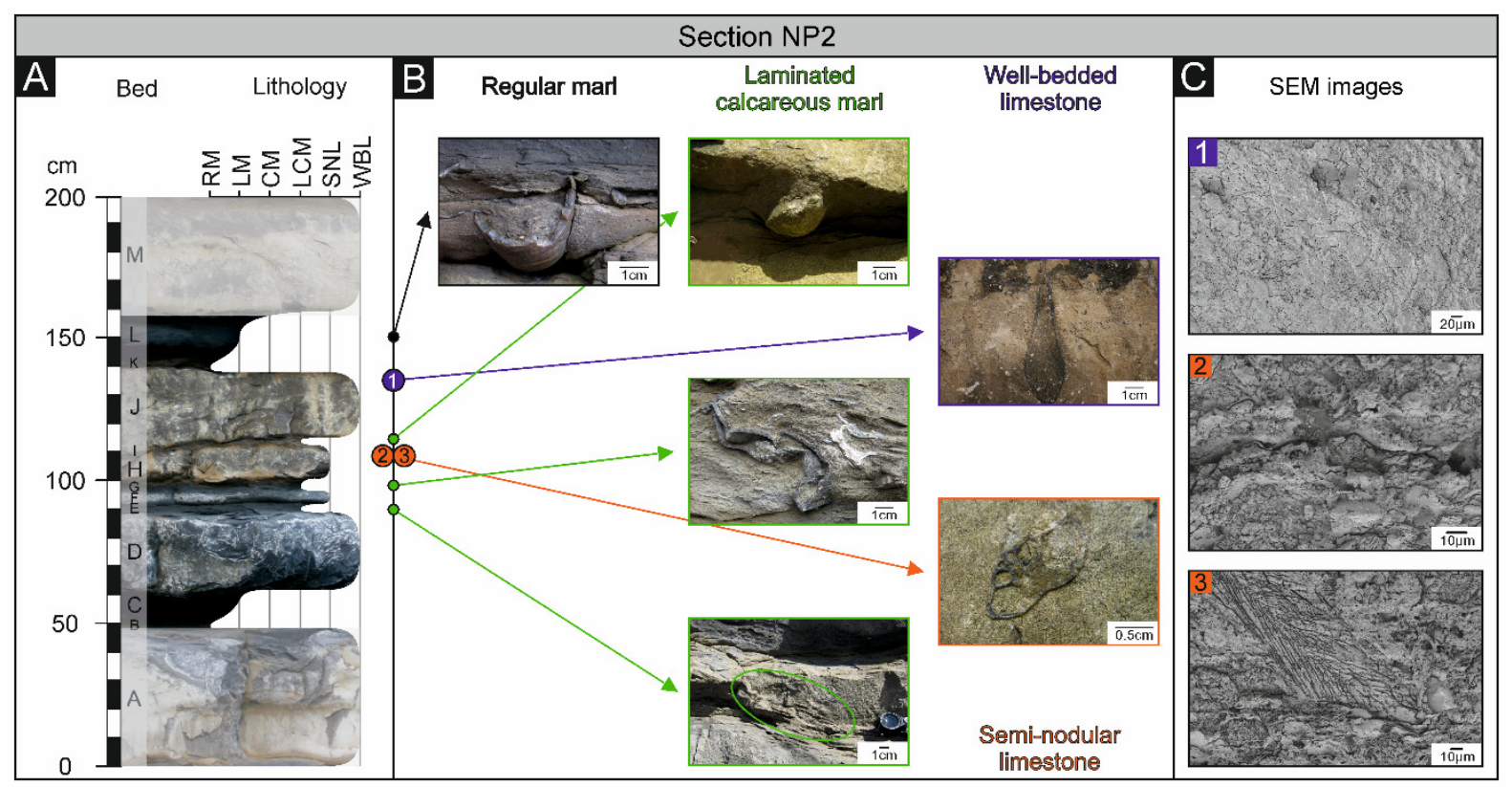

Figure 8.6: Diagenetic features in subsection NP2. A) Sedimentological subsection with six different lithologies $(\mathrm{WBL}=$ well-bedded limestones, $\mathrm{SNL}=$ semi-nodular limestones, $\mathrm{CM}=$ calcareous marls, $\mathrm{LCM}=$ laminated calcareous marls, $\mathrm{RM}=$ regular marls, $\mathrm{LM}=$ laminated marls); B) Field photos highlighting differential compacted microfossils; C) Selected SEM images from limestone bed $\mathrm{J}(1)$ and $\mathrm{H}$ (2 and 3)

laminated calcareous marl is gradual (Fig. 8.6A; Afşar et al., 2014; see chapter 2 for details). Bivalves (e.g. Pinna sp.) and gastropods in limestones are preserved in-situ and are not secondarily deformed (beds $\mathrm{H}$ and J; Fig. 8.6B), the same applies to bivalves in the thicker marl interbed (e.g. Gryphaea sp. in interbed L; Fig. 8.6B). In contrast, bivalves in laminated calcareous marls (e.g. Gryphaea sp. in interbeds E and G; Fig. 8.6B) are strongly deformed. Scanning electron microscopy exhibited that clay minerals were slightly oriented around components such as fossil fragments (transition from bed $\mathrm{H}$ to interbed I; Fig. 8.6C). The observed differential compaction in limestones (beds $\mathrm{H}$ and J; Fig. 8.6B) and laminated calcareous marls (interbeds E and G; Fig. 8.6B) may be explained for this metre scaled succession by dissolution- and cementation-processes during early diagenesis (cf. Ricken, 1986; Westphal et al., 2000; Munnecke and Westphal, 2005). The lack of aragonitic fossils in the marls and the contemporaneous preservation of gastropods (initially aragonitic shell mineralogy) with recrystallised shells in the limestone beds could indicate a very early dissolution of aragonite immediately after deposition and a subsequent rapid void-filling precipitation of calcite in the limestone beds. However, these observations could not be confirmed by means of SEM analyses (for example etched aragonite components in the marls). 
Subsection NP3 is characterised by semi-nodular limestones (Fig. 8.7A). The limestone beds and marl interbeds in subsection NP3 are well-differentiated as the ones in the NP2 subsection. One further important feature is the presence of elliptical limestone nodules isolated within regular marl interbeds (Fig. 8.7B). These nodules are assumed to be diagenetic in origin (cf. Wobber, 1965) and show signs of sliding around these nodules, indicating physical compaction (Fig. 8.7B; Afşar et al., 2014; see chapter 6 for details). However, no evidences for differential compaction were observed in both marl interbeds and limestone beds by means of scanning electron microscopy (Fig. 8.7C). The observed signs of sliding would nonetheless be associated with a rapid burial due to high sedimentation rates, subjecting the semi-lithified sediments to a high overburden pressure during the early postdepositional stage.

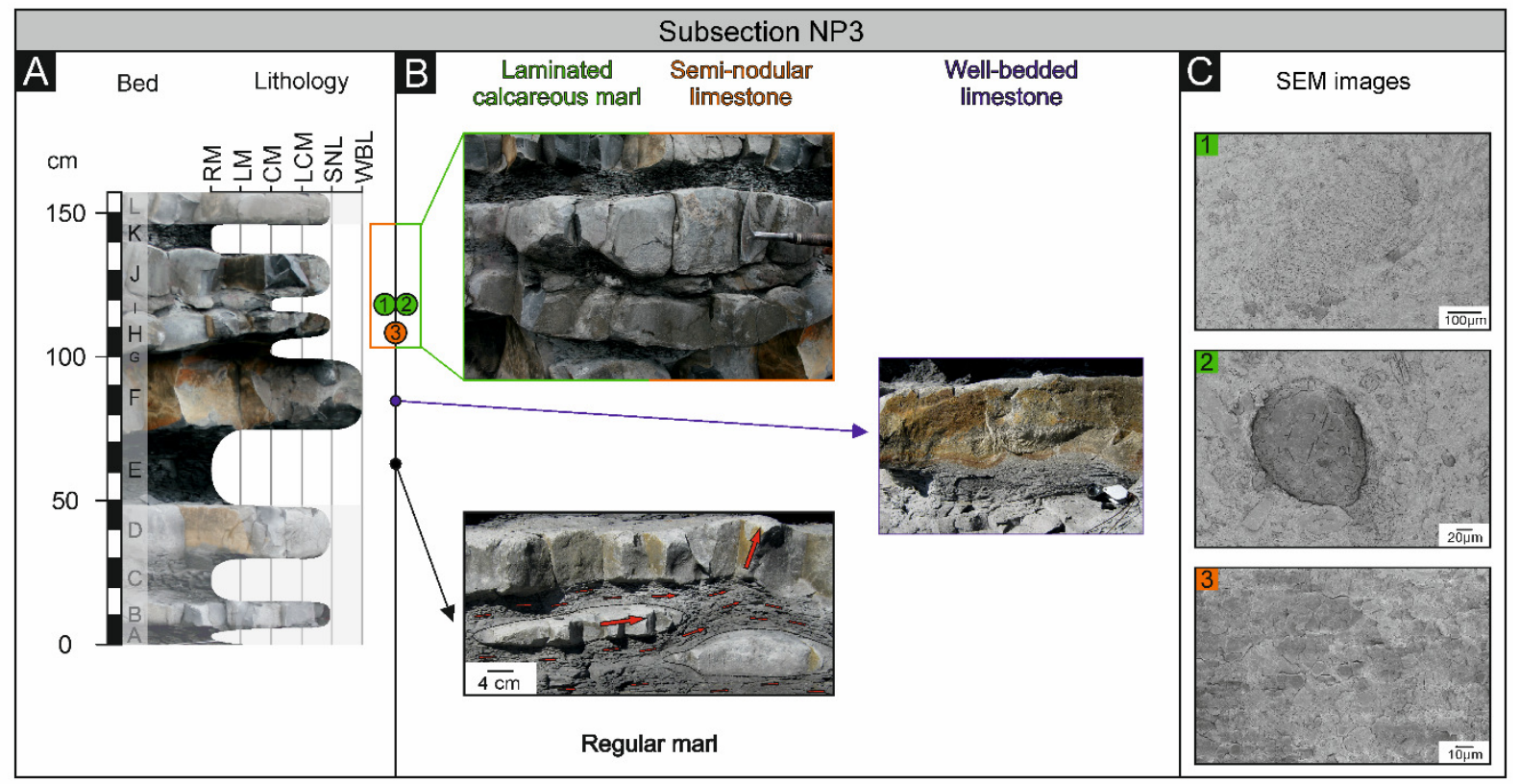

Figure 8.7: Diagenetic features in subsection NP3. A) Sedimentological subsection with six different lithologies $(\mathrm{WBL}=$ well-bedded limestones, $\mathrm{SNL}=$ semi-nodular limestones, $\mathrm{CM}=$ calcareous marls, $\mathrm{LCM}=$ laminated calcareous marls, $\mathrm{RM}=$ regular marls, $\mathrm{LM}=$ laminated marls); B) Field photos highlighting signs of physical compaction through overburden pressure; C) Selected SEM images from limestone bed I (1 and 2) and H (3).

\subsubsection{Impact of diagenesis on fracture-associated permeability in limestone-marl alternation}


The connectivity of fracture networks and hence the fracture-associated permeability in layered sedimentary rocks, vary considerably between distinct layers (Philipp et al., 2013; see chapter 9 for details). However, not only the mechanical layering (i.e. change of mechanical properties between different layers) but also the cohesive bond of lithological contacts, is crucial for preventing the vertical fracture extension (e.g. Price, 1966; Hobbs, 1967; Philipp et al., 2013 Afşar et al., subm.; see chapter 7 and 9 for details).

Major faults between the three subsections belong to a series of conjugated strike-slip faults striking in N-S-direction (Fig. 8.8A,D,E,F). Fractures in NP1 and 2 strike in E-W-direction and are perpendicular oriented to the next faults (Fig. 8.8B). In contrast, fractures in NP3 strike in N-S-direction and thus are parallel to the adjacent fault (Fig. 8.8B). Since the throws of all faults range only between 1.9 and $2.6 \mathrm{~m}$, the stratigraphic offset between the three subsections appears to be negligible (Fig. 8.8C).

Subsection NP1 with more well-bedded limestones reveals, compared to subsection NP2, lower percentages of non-stratabound fractures and higher percentages of fracture terminations at lithological contacts (Fig. 8.9). Subsection NP2 comprises well-bedded and semi-nodular limestones and is characterised by high percentages of non-stratabound fractures and low percentages of fracture terminations at semi-nodular limestone/calcareous marlcontacts (e.g. between $\mathrm{G}$ and H; Fig. 8.9) as well as by high percentages of fracture terminations at well-bedded limestone/regular marl-contacts (e.g. between $\mathrm{C}$ and $\mathrm{D} ; \mathrm{J}$ and $\mathrm{K}$; Fig. 8.9). Subsection NP3 comprises more semi-nodular limestones and is characterised by higher percentages of non-stratabound fractures and lower percentages of fractures terminating comparable with NP1 (Fig. 8.9). Based on the number of fracture terminations at the lithological contacts the bond of semi-nodular limestone/calcareous marl-contacts in subsection NP2 appears stronger compared to the well-bedded limestone/regular marl contacts and thus these contacts are more welded (Fig. 8.9). A possible explanation for welded contacts (e.g. between G and H in NP2) could be the proceeding differentiation of an almost homogenous mud sediment. After deposition, $\mathrm{CaCO}_{3}$ is potentially dissolved in carbonate-poor interlayers and subsequently re-precipitated in layers initially enriched in carbonates ('differential diagenesis'; Ricken, 1986). Thus, lithological contacts in diagenetic influenced successions tend to be more gradual and are consequently no mechanical interfaces, if additionally the contrast of $\mathrm{CaCO}_{3}$ contents between limestones and marls is low, the succession can be defined as a mechanical unit which promotes the fracture propagation. 

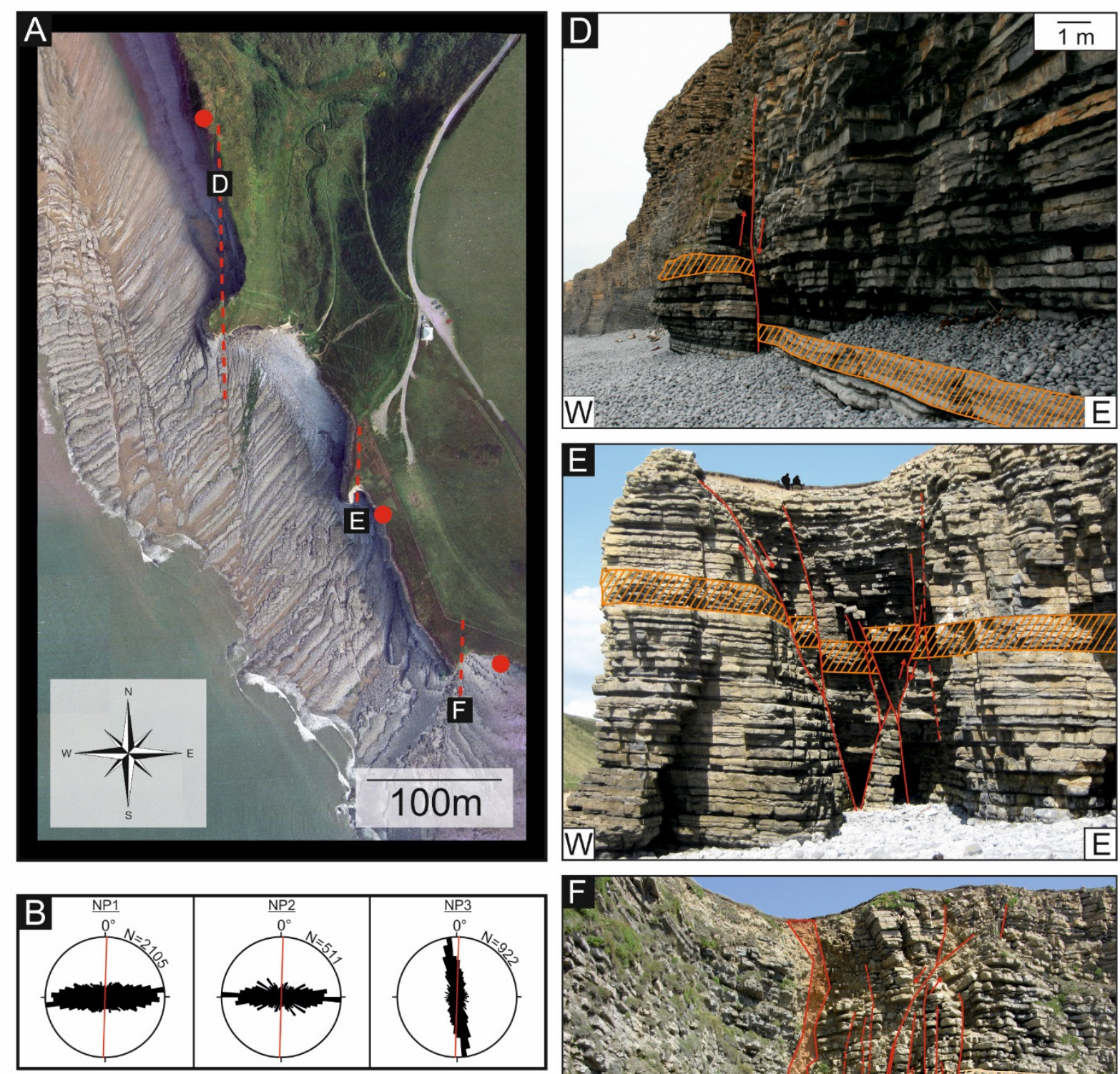

\begin{tabular}{|c|c|c|c|c|c|}
\hline & Section & $\begin{array}{c}\text { Distance to } \\
\text { next } \\
\text { fault }[\mathrm{m}]\end{array}$ & $\begin{array}{c}\text { Fault throw } \\
{[\mathrm{m}]}\end{array}$ & $\begin{array}{l}\text { Fault } \\
\text { strike }\end{array}$ & $\begin{array}{c}\text { Strike of main } \\
\text { fracture set }\end{array}$ \\
\hline D & NP1 & 4 & 2.6 & $\mathrm{~N}-\mathrm{S}$ & E-W \\
\hline$E$ & NP2 & 15 & 1.9 & $\mathrm{~N}-\mathrm{S}$ & E-W \\
\hline$F$ & NP3 & 13 & 2 & N-S & $\mathrm{N}-\mathrm{S}$ \\
\hline
\end{tabular}

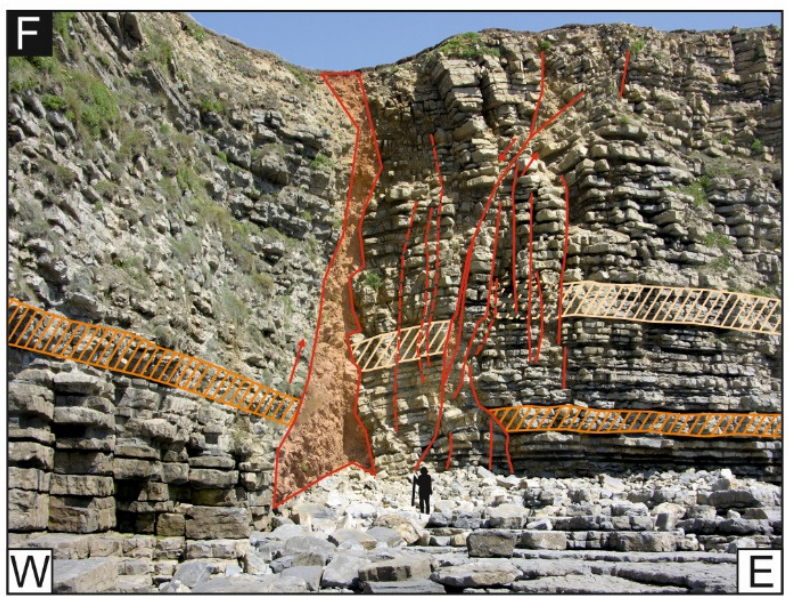

Figure 8.8: Documentation of major faults between the investigated subsections. A) Location of all three subsections (red dots) and intersecting faults (dotted red lines); B) Symmetrical rose diagrams of fracture strikes including the number of measured fracture segments $(\mathrm{N})$ and the strike of the closest major fault (red line) (Afşar et al., 2014; see chapter 6 for details); C) Summary of fault- and fracture-related data (Afşar et al., 2014; see chapter 6 for details); D-F) Field photos of the intersecting faults (see A for exact positions). Relative fault throws were measured by reference horizons, here it is a distinct nodular bed unit (hatched area in orange) from subsection NP1 (D), subsection NP2 (E) and subsection NP3 (F). 

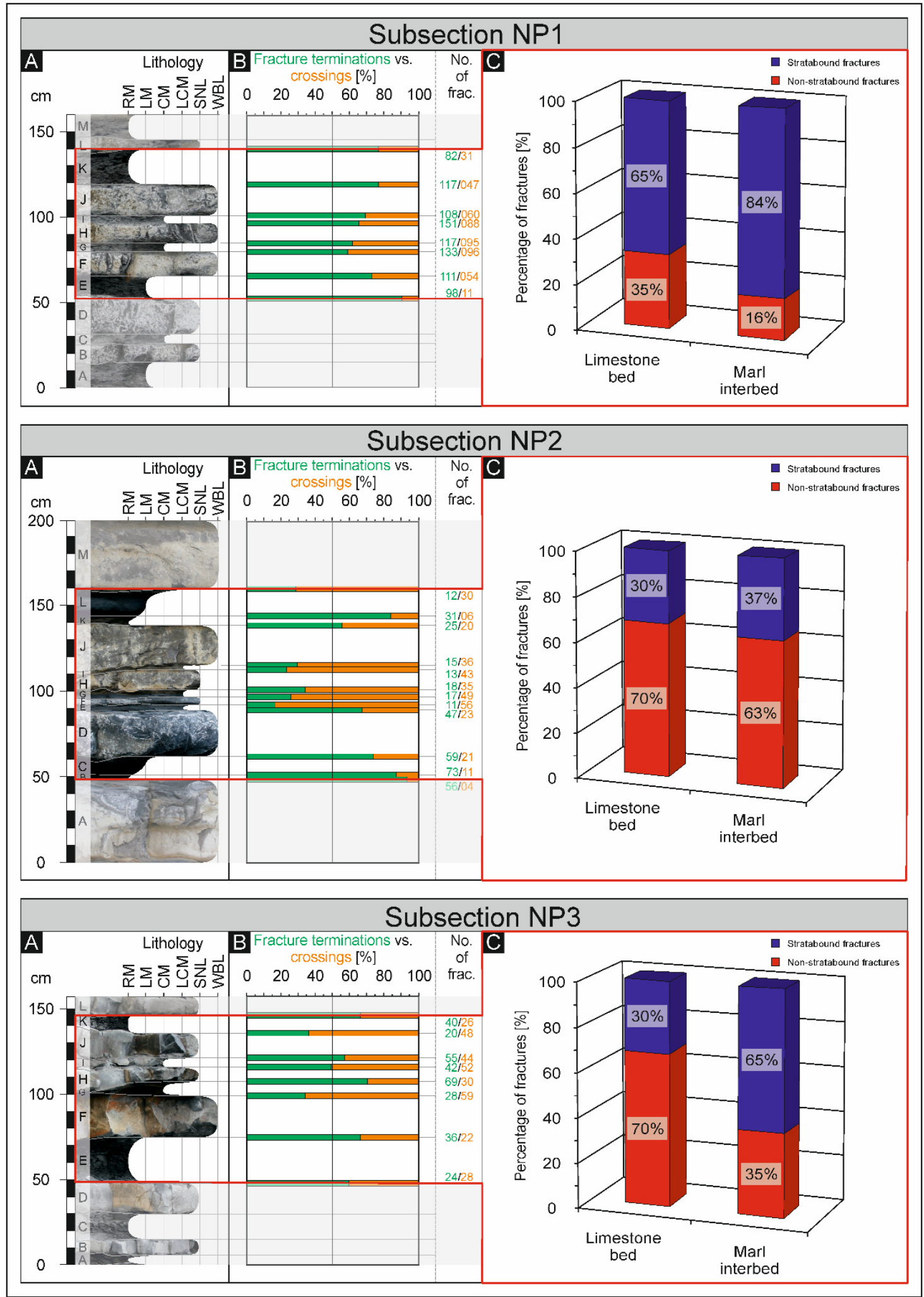

Figure 8.9: Quantification of vertical fracture extension from subsection NP1,NP2 and NP3. A) Sedimentological sections; the break-off illustrates differences in lithology and is not scaled $(\mathrm{WBL}=$ well-bedded limestones, $\mathrm{SNL}=$ semi-nodular limestones, $\mathrm{CM}=$ calcareous marls, $\mathrm{LCM}=$ laminated calcareous marls, $\mathrm{RM}=$ regular marls, $\mathrm{LM}=$ laminated marls); $\mathrm{B}$ ) Percentages of fracture terminations at lithological contacts; C) Percentages of nonstratabound fractures in limestone beds and marl interbeds. 


\subsection{Conclusions}

The stratigraphic offset between three several meters thick subsections (NP1-NP3) of LMA of the Blue Lias Formation (Hettangian-Sinemurian; Wales, UK) is probably negligible given the close vicinity of the localities ( $<500 \mathrm{~m}$ linear distance) and the minor throws (ca. 1.9 to $2.6 \mathrm{~m}$ ) of intersecting major faults. Despite this close vicinity and relative contemporaneous time of deposition, all of the three subsections are characterised by different main sedimentological and diagenetic features. The diagenetic features observed from metre to micrometre scale evidence early lithification in subsection NP1, and physical compaction in subsection NP2 (due to differential compaction processes) and subsection NP3 (due to overburden pressure). However, in case of all subsections no evidences for (differential) compaction were observed on the micrometre scale (SEM analyses). At the same time, all three subsections are characterised by dissimilar patterns of vertical fracture extension, implying that diagenetic features have a strong impact on vertical fracture propagation. Diagenetic influenced successions such as subsection NP2 can be defined as a mechanical unit which promotes the fracture propagation.

\section{Acknowledgments}

We thank the Deutsche Forschungsgemeinschaft (DFG, grant PH 189/2-1) and the International Association of Sedimentologists (IAS, postgraduate grant scheme, $2^{\text {nd }}$ session) for financial support. We are indebted to Prof. Joachim Reitner (Department of Geobiology, Georg-August University of Göttingen) and Dr Axel Munnecke (Palaeontology Group at the GeoZentrum Nordbayern, Friedrich-Alexander-University of Erlangen-Nürnberg) for providing facilities and constructive discussions. Sebastian Flotow (Leibniz Centre for Tropical Marine Ecology), Dr Sebastian Teichert (Palaeontology Group at the GeoZentrum Nordbayern, Friedrich-Alexander-University of Erlangen-Nürnberg) and Dorothea HauseReitner (Department of Geobiology, Georg-August University of Göttingen) are thanked for technical support. We acknowledged Dr Jan-Peter Duda for constructive discussions and Annika Steichert for proof reading.

\section{References}

Afşar F., Westphal H., Philipp S.L. (2014) How facies and diagenesis affect fracturing of limestone beds and reservoir permeability in limestone-marl alternations. Marine and Petroleum Geology, 57, 418-432.

Afşar F., Westphal H., Philipp S.L. (submitted) Effects of stress barriers on reservoir permeability in layered rocks: A case study of Blue Lias rhythms (Bristol Channel Basin, UK). American Association of Petroleum Geologists Bulletin.

Bloos G., Page K.N. (2002) Global stratotype section and point for base of the Sinemurian Stage (Lower Jurassic). Episodes, 25, 22-28. 
Flügel E. (2010) Microfacies of Carbonate Rocks Analysis, Interpretation and Application. Second ed., with a contribution by Axel Munnecke. Springer, Heidelberg.

Hallam A. (1960) A sedimentary and faunal study of the Blue Lias of Dorset and Glamorgan. Philosophical Transactions of the Royal Society B, 243, 1-44.

Hobbs D.W. (1967) The formation of tension joints in sedimentary rocks: An Explanation. Geological Magazine, 104, 550-556.

Munnecke A., Westphal H. (2005) Variations in primary aragonite, calcite, and clay in finegrained calcareous rhythmites of Cambrian to Jurassic age - an environmental archive? Facies, 51, 592-607.

Odling N.E., Gillespie P., Bourgine B., Castaing C., Chilés J.-P., Christensen N.P., Fillion E., Genter A., Olsen C., Thrane L., Trice R., Aarseth E., Walsh J.J., Watterson J. (1999) Variations in fracture system geometry and their implications for fluid flow in fractured hydrocarbon reservoirs. Petroleum Geoscience, 5, 373-384

Philipp S.L., Afşar F., Gudmundsson A. (2013) Effects of mechanical layering on hydrofracture emplacement and fluid transport in reservoirs. Frontiers of Earth Science, 1, 1-19.

Price N.J. (1966) Fault and Joint Development in Brittle and Semi-Brittle Rock. Pergamon Press, London.

Rawnsley K.D., Peacock D.C.P., Rives T., Petit J.-P. (1998) Joints in the Mesozoic sediments around the Bristol Channel Basin. Journal of Structural Geology, 20, 1641-1661.

Ricken W. (1986) Diagenetic bedding: A model for marl-limestone alternations. In: Bhattacharji S., Friedman G.M., Neugebauer H.J., Seilacher A. (Eds.) Lecture Notes in Earth Sciences. Springer-Verlag, Berlin Heidelberg, pp.1-210.

Sheppard T.H., Houghton R.D., Swan A.R.H. (2006) Bedding and pseudo-bedding in the early Jurassic of Glamorgan: deposition and diagenesis of the Blue Lias in South Wales. Proceedings of the Geologists' Association, 117, 249-264.

Weedon G.P. (1986) Hemipelagic shelf sedimentation and climatic cycles: The basal Jurassic (Blue Lias) of South Britain. Earth and Planetary Science Letters, 76, 321-335.

Westphal H., Head M.J., Munnecke A. (2000) Differential diagenesis of rhythmic limestone alternations supported by palynological evidence. Journal of Sedimentary Research, 70, 715-725.

Westphal H., Munnecke A., Böhm F., Bornholdt S. (2008) Limestone-marl alternations in epeiric sea settings - witnesses of environmental changes, or of rhythmic diagenesis? In: Holmden C., Pratt B.R. (Eds.) Dynamics of Epeiric Seas: Sedimentological, Paleontological and Geochemical Perspectives. Geological Association of Canada Special Paper, pp. 1-20.

Wobber F.J. (1965) Sedimentology of the Lias (Lower Jurassic) of South Wales, Journal of Sedimentary Petrology, 35, 683-703. 


\title{
-Chapter 9-
}

\section{Effects of mechanical layering on hydrofracture emplacement and fluid transport in reservoirs}

\author{
Sonja L. Philipp ${ }^{\text {a, }}$, Filiz Afşar ${ }^{\text {a }}$, Agust Gudmundsson ${ }^{\mathrm{b}}$ \\ ${ }^{a}$ University of Göttingen, Geoscience Centre (GZG), Structural Geology and Geodynamics, Goldschmidtstraße \\ 3, D-37077 Göttingen, Germany. \\ ${ }^{b}$ Royal Holloway, University of London, Department of Earth Sciences, Egham, Surrey, TW20 OEX, United \\ Kingdom.
}

*Correspondence: sonja.philipp@geo.uni-goettingen.de

Frontiers in Earth Science (2013) 1, 1-19

\begin{abstract}
Fractures generated by internal fluid pressure, for example, dykes, mineral veins, many joints and man-made hydraulic fractures, are referred to as hydrofractures. Together with shear fractures, they contribute significantly to the permeability of fluid reservoirs such as those of petroleum, geothermal water, and groundwater. Analytical and numerical models show that in homogeneous host rocks - any significant overpressure in hydrofractures theoretically generates very high crack tip tensile stresses. Consequently, overpressured hydrofractures should propagate and help to form interconnected fracture systems that would then contribute to the permeability of fluid reservoirs. Field observations, however, show that in heterogeneous and anisotropic, e.g. layered, rocks many hydrofractures become arrested or offset at layer contacts and do not form vertically interconnected networks. The most important factors that contribute to hydrofracture arrest are discontinuities (including contacts), stiffness changes between layers, and stress barriers, where the local stress field is unfavorable to hydrofracture propagation. A necessary condition for a hydrofracture to propagate to the surface is that the stress field along its potential path is everywhere favorable to extension-fracture formation so that the probability of hydrofracture arrest is minimised. Mechanical layering and the resulting heterogeneous stress field largely control whether evolving hydrofractures become confined to single layers (stratabound fractures) or not (nonstratabound fractures) and, therefore, if a vertically interconnected fracture system forms. Non-stratabound hydrofractures may propagate through many layers and generate interconnected fracture systems. Such systems commonly reach the percolation threshold and largely control the overall permeability of the fluid reservoirs within which they develop.
\end{abstract}




\subsection{Introduction}

A hydrofracture is a fracture partly or wholly generated by internal fluid pressure. The term 'hydrofracture' is well established for fluid-driven rock fractures, including mineral veins and (igneous and clastic) dykes, as well as many joints (e.g. Davis, 1983; Rummel, 1987; Sleep and Fujita, 1997; Rijsdijk et al., 1999; Bons, 2001; Gudmundsson, 2011a; Gundersen et al., 2011; Bons et al., 2012). Hydraulic fractures, that is, man-made fractures generated by fluid overpressure and injected into reservoir rocks to increase their permeabilities (e.g. Hubbert and Willis, 1957; Charlez, 1997; Yew, 1997; Mahrer, 1999; Economides and Nolte, 2000), are also considered hydrofractures.

Even if the fluid properties of oil, water and magma (particularly their densities and viscosities) are quite different, the basic physical principles are the same for all kinds of hydrofractures (cf. Mandl, 2005). In many hydrofractures, for example those generated by gas, oil, or groundwater pressure or man-made hydraulic fractures, the fluid may disappear (diffuse or flow out) after the fracture has formed. This is presumed to be the case for the formation of many joints, as initially suggested by Secor (1965). Other hydrofractures, including dykes and mineral veins are driven open by fluids that solidify or precipitate in the fracture once it has formed. In the latter case the fracture tips, and the mechanisms of fracture emplacement, can be more easily studied. Studies of their cross-cutting relationships (where the relative displacements of fractures cut by later fractures are considered) indicate that most paleohydrofractures are extension fractures (e.g. Gudmundsson et al., 2002). Since outcropscale absolute tension cannot occur at depths greater than a few hundred meters (Twiss and Moores, 2006), most extension fractures, in turn, could only be formed as hydrofractures.

Hydrofracture paths are major conduits for fluid transport in the crust. Therefore, the conditions of hydrofracture emplacement are of vital importance in fields such as gas, petroleum and geothermal exploration, waste studies, seismology, volcanology, hydrogeology and $\mathrm{CO}_{2}$-sequestration (e.g. Bonafede and Danesi, 1997; Ingebritsen and Sanford, 1998; Hardebeck and Hauksson, 1999; Dahm, 2000; Economides and Nolte, 2000; Cobbing and O'Dochartaigh, 2007; Chiaramonte et al., 2008). In fact, the formation of hydrofractures is one of the main mechanisms for the generation and maintenance of permeability, particularly in fluid-filled heterogeneous reservoirs such as those associated with petroleum, groundwater, volcanic and geothermal fields. Although the dynamics of fluid accumulation and transport in fractured reservoirs are topics of great current interest (e.g. Coward et al., 1998; Rossmanith, 1998; Faybishenko et al., 2000; Kümpel, 2003; Lonergan et al., 2007; van Golf-Racht, 2009; 
Bourbiaux, 2010; Spence et al., 2013), the formation of hydrofractures and their potential effects on permeability have received less attention than they deserve.

When a reservoir consists of numerous layers, stratabound hydrofractures contribute little if anything to its overall vertical permeability. For such a reservoir, the permeability is necessarily dominated by fractures that propagate through many layers, that is, nonstratabound fractures. In volcanic hazard studies the propagation of magma-driven fractures (dykes) outside, rather than inside, the reservoirs is of importance. Composite volcanoes are layered, and the layers often have contrasting mechanical properties (Gudmundsson, 2006). Some of these layers develop local stresses which are unfavorable to dyke propagation. Consequently, most dykes become arrested and never reach the surface to feed volcanic eruptions (Gudmundsson, 2006; Stewart et al., 2003; Gudmundsson and Brenner, 2005; Martí and Geyer, 2009).

Growth of a hydrofracture depends on its fluid pressure as well as on the mechanical properties of the host rock. Many models of hydrofracture propagation assume the mechanical properties of the host rock to be homogeneous and isotropic (Spence and Turcotte, 1985; Lister and Kerr, 1991; Rubin, 1995; Flekkoy et al., 2002; Al-Busaidi et al., 2005). These assumptions make the problem mathematically tractable, and the resulting analytical models highlight the basic physics involved in hydrofracture development. These models are, however, of limited applicability to fluid reservoirs composed of heterogeneous and anisotropic rocks. In reservoirs, heterogeneities range in sizes from grains to entire basins. But for the propagation of hydrofractures perhaps the most important heterogeneity in reservoirs is mechanical layering (Economides and Nolte, 2000).

\subsection{Reservoir fractures and fluid transport}

\subsubsection{Models of reservoir fractures}

Fractures control the permeability of many reservoirs and the relation between fracturing and fluid flow is currently a topic of extensive research (e.g. Vigneresse, 2001; Berkowitz, 2002; Labaume et al., 2002; Neuzil, 2003; Dietrich et al., 2005; Dresen et al., 2006; Sahimi, 2011; Adler et al., 2012). Fractures are very efficient paths for the migration of hydrocarbons in reservoirs (Mandl and Harkness, 1987; Aydin, 2000; Nunn and Meulbroek, 2002). A rock body with fractures that have significant effect on its fluid transport is a 'fractured reservoir' (Nelson, 1985; 2001; Aguilera, 1995). 
Rock fractures may be classified in various ways (e.g. Stearns and Friedman, 1972; Nelson, 1985; Price and Cosgrove, 1990; Priest, 1992; Davis and Reynolds, 1996; van der Pluijm and Marshak, 2003; Twiss and Moores, 2006; Gudmundsson, 2011a). Depending on the relative displacement across the fracture plane, however, all reservoir fractures are either extension fractures or shear fractures. Extension fractures include tension fractures (formed in absolute tension) and hydrofractures. For extension fractures, the relative displacement is perpendicular to, and away from, the fracture plane. For shear fractures the relative displacement is parallel to the fracture plane. Shear fractures with significant or large displacements are commonly referred to as faults.

For modeling rock fractures in reservoirs, three crack modes are used (Fig. 9.1; e.g. Broberg, 1999). Extension fractures are modeled as mode I cracks (Fig. 9.1). Shear fractures are modeled as either mode II or mode III cracks depending on whether the crack-tip displacement is perpendicular or parallel to the leading edge (tip) of the crack (Fig. 9.1).

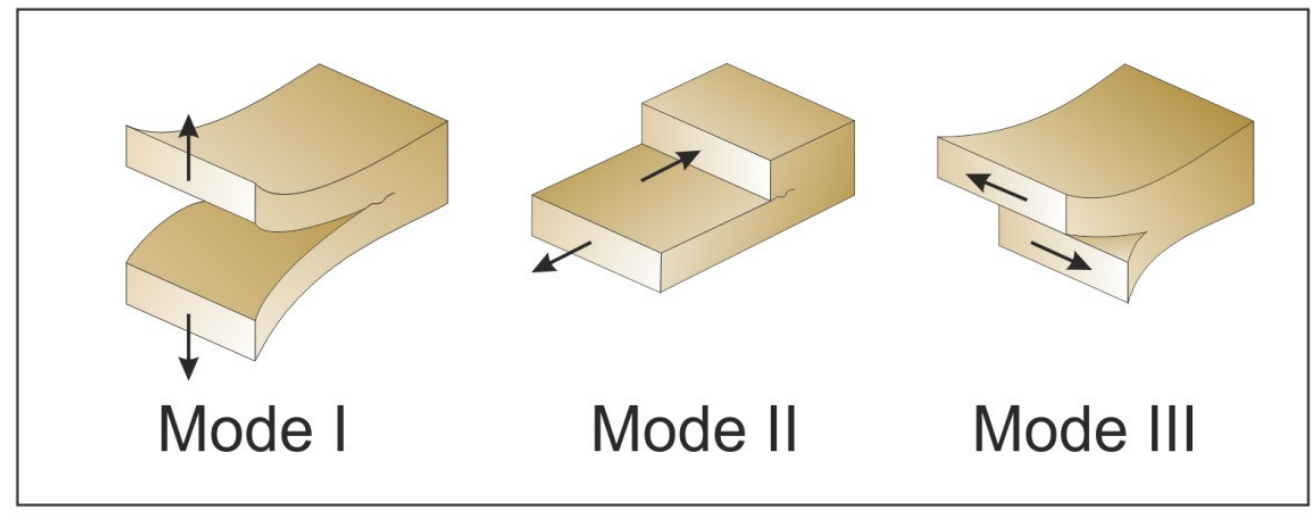

Figure 9.1: Crack modes used in modeling rock fractures in a reservoir: In a mode I crack, the relative displacement is perpendicular to, and away from, the fracture plane (extension fractures). In mode II and III crack-tip displacement is parallel to the fracture plane: in mode II perpendicular, in III parallel to the leading edge (tip) of the crack. There are various combinations of these basic types (modified from Hudson and Harrison, 1997).

The various combinations of these basic types include mixed-mode cracks ('hybrid cracks') where, commonly, mode I displacement is mixed with either mode II or mode III displacement (Hudson and Harrison, 1997). The displacement on a crack is largely determined by its controlling dimension (Gudmundsson, 2000b). The controlling dimension is the smaller of the strike and dip dimension. The horizontal (strike) dimension of a fracture, measured as linear distance between its ends in a lateral outcrop, is referred to as its length, the vertical (dip) dimension as its height (Fig. 9.2). The maximum thickness or fracture 
dimension measured perpendicular to the fracture walls is the aperture or opening of the fracture (Fig. 9.2).
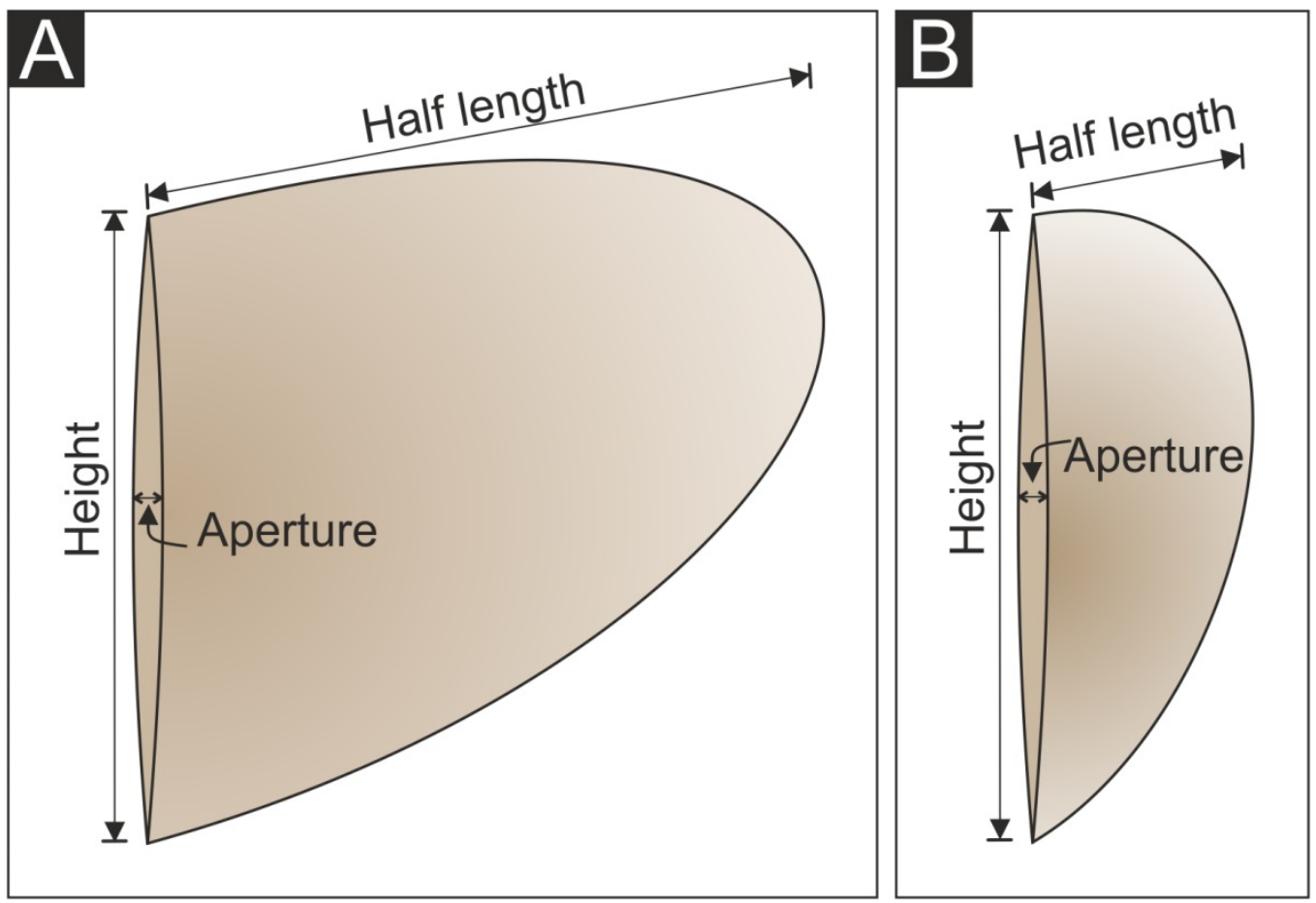

Figure 9.2: The length of a fracture is its horizontal (strike) dimension, its height is the vertical (dip) dimension, and its aperture is the maximum thickness measured perpendicular to the fracture walls; A) If the height is smaller than the length, the fracture aperture is correlated to the fracture height;. B) If the height is larger than the length, the fracture aperture correlates with the fracture length. The smaller of the strike and dip dimension is therefore referred to as the controlling dimension of the fracture (Gudmundsson, 2000b).

That is, if the height is smaller than the length (Fig. 9.2A), the fracture aperture is correlated with the fracture height. If, however, the height is larger than the length (Fig. 9.2B), the fracture aperture correlates with the fracture length.

As regards shape, any simple two-dimensional fracture (when the aperture and its variation are neglected) can be modeled as one of three basic ideal elastic crack types (Fig. 9.3; Atkins and Mai, 1985): (i) through crack (a through-the-thickness crack) that extends through the whole layer containing the crack, from one free rock surface to another; (ii) part-through crack (a thumbnail crack) that extends from a free surface of the rock body and partly into it; and (iii) interior crack is elliptical and located in the interior of the rock body hosting the crack, the body being regarded as infinite. The penny-shaped crack is the special case of a circular interior crack. Before stress/pressure causes displacement of the crack surfaces, the cracks are regarded as mathematical, that is, the aperture is effectively zero. 


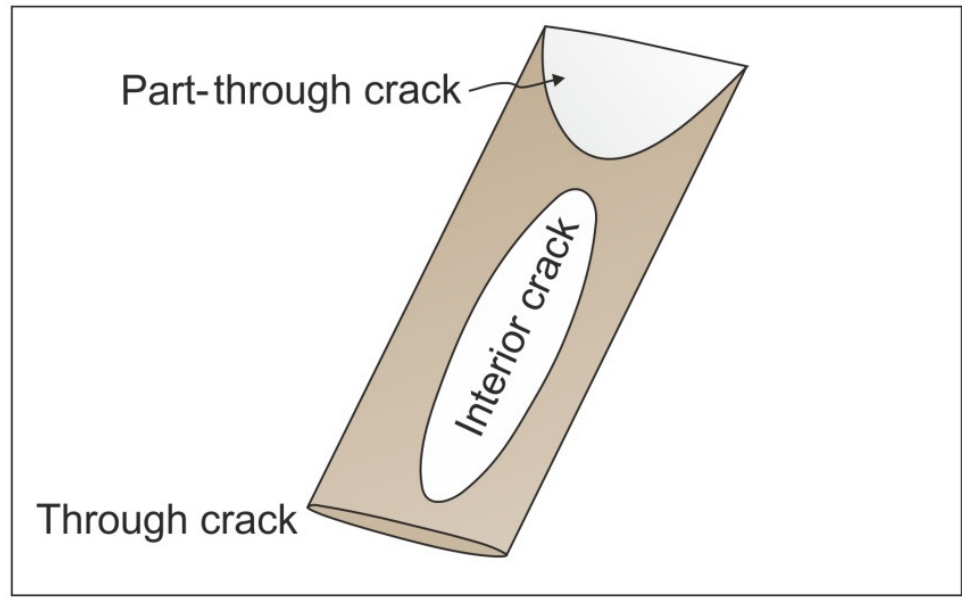

Figure 9.3: Crack shapes of idealised two-dimensional fractures (when the aperture is neglected) used in modeling rock fractures in a reservoir: A through crack extends through the whole layer containing the crack, from one free rock surface to another. A part-through crack extends from a free surface of the rock body and partly into it. An interior crack is elliptical and located in the interior of the rock body hosting the crack, the body being regarded as infinite (modified from Gudmundsson 2000b).

\subsubsection{Fluid flow in fractured rocks}

In most solid low-porosity rocks, fluid flow occurs primarily through the fractures that form later than the host rocks themselves and constitute a secondary porosity (Nelson, 1985; Singhal and Gupta, 1999). Despite its importance, fluid flow in fractured rocks is still not well understood (e.g. Singhal and Gupta, 1999; Faybishenko et al., 2000; Berkowitz, 2002).

When modeling fluid flow in a single, isolated fracture, the fracture is often idealised as having smooth, parallel walls (Fig. 9.4).

For such a fracture, a special solution of the Navier-Stokes equations for the flow of a viscous fluid is commonly used. This solution predicts that the volumetric flow rate is proportional to the cube of the aperture of the fracture through which the fluid flows. Particularly in hydrogeology, this solution is referred to as the 'cubic law' (de Marsily, 1986). The host-rock is normally assumed to respond to fluid flow in a fracture in one of two basic ways: rigidly or elastically (Fig. 9.5). In many models of fluid flow in rock fractures in the uppermost part of the crust, the host rock is assumed to be perfectly rigid, so that it does not deform due to changes in stress or fluid pressure (e.g. Bear, 1993; Taylor et al., 1999).

The fracture and its fluid source then behave as self-supporting. This means that when fluid is added to, or withdrawn from, an aquifer or reservoir, so that its pressure changes, the aquifer/reservoir volume remains the same. In other words, the aquifer/reservoir does not feel the weight of the overburden. Buoyancy, which derives from the weight of the overburden in 
relation to the weight of a vertical column of a fluid (or, more specifically, the density difference between the host rock and the fluid) has therefore no effects on the pressure gradient of the fluid.

The volumetric flow rate $Q_{D}^{s}$, with the superscript $s$ denoting self-supporting fracture and source and the subscript $D$ the length of the dip-dimension of the fracture along which the flow takes place, is given by (Gudmundsson et al., 2002; Gudmundsson, 2011a):

$Q_{D}^{s}=\frac{b^{3} W}{12 \mu}\left(\rho_{f} g \sin \alpha-\frac{\partial p_{e}}{\partial D}\right)$

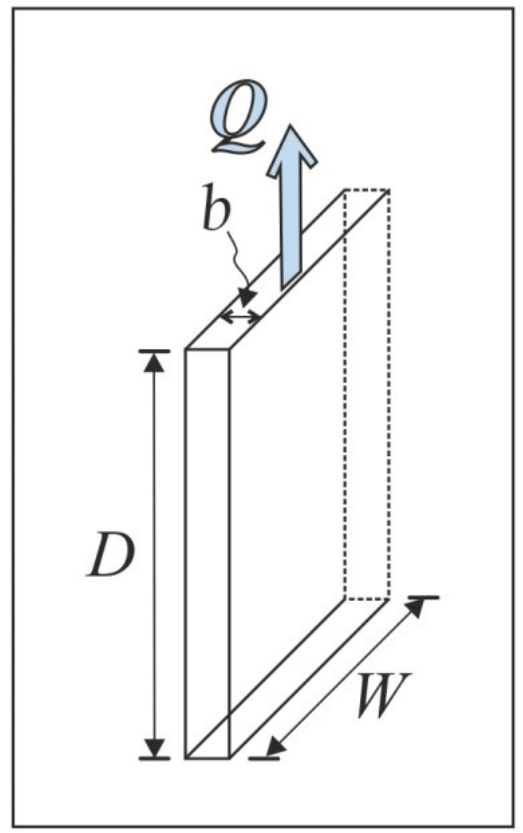

where $b$ is the fracture aperture, $W$ the fracture width perpendicular to the flow direction (Figs. $9.3 \& 9.4$ ), $\mu$ the dynamic (absolute) fluid viscosity, $\rho_{f}$ the fluid density, $g$ the acceleration due to gravity, $\alpha$ the fracture dip, and $\partial p_{e} / \partial D$ the excess pressure gradient (where the excess fluid pressure $p_{e}$ is the pressure in excess of the minimum principal compressive stress $\sigma_{3}$ in the roof of the source; see section below). For a

Figure 9.4: Parallel-plate model for modeling fluid flow in a single, isolated fracture. The fracture is idealised as having smooth, parallel walls. Here $Q$ is the volumetric flow rate, $W$ the fracture width perpendicular to the flow direction, $D$ the length of the dip-dimension of the fracture along which the flow takes place (cf. Fig. 9.5), and $b$ is the fracture aperture. vertical fracture, the $\operatorname{dip} \alpha=90^{\circ}$, the term $(\sin \alpha)$ becomes 1 and can thus be omitted. More realistically, the host rock, the fracture, and the fluid source may deform during the fluid transport. For the upper crust, this means that they behave as elastic and the weight of the rock above the source is supported by the fluid pressure in the source. Because the density of the host rock, $\rho_{r}$, is different from that of the fluid, $\rho_{f}$, buoyancy must then be taken into account in Eq. (1). The volumetric rate of fluid flow in an elastic fracture (denoted by the superscript $e$ ) is then (Gudmundsson et al., 2002; Gudmundsson, 2011a):

$$
Q_{D}^{e}=\frac{b^{3} W}{12 \mu}\left(\left(\rho_{r}-\rho_{f}\right) g \sin \alpha-\frac{\partial p_{e}}{\partial D}\right)
$$


The cubic law for single fractures can be extended to fracture sets, as has been done for fracture sets in rigid host rocks (Bear, 1993; Singhal and Gupta, 1999).

The use of Eqs. (1) and (2) can be illustrated with an example of the calculation of the volumetric flow rate through a typical fracture transporting water. We assume smooth parallel fracture walls, so that there is no flow channeling. The fracture occurs at a crustal depth of 3 $\mathrm{km}$, is vertical $\left(\alpha=90^{\circ}\right)$ with a width $W$ (perpendicular to the flow direction) of $500 \mathrm{~mm}$ and an aperture $b$ of $1 \mathrm{~mm}$ (Fig. 9.4). For water at $90^{\circ} \mathrm{C}$ the dynamic viscosity $\mu$ is $3.15 \times 10^{-4} \mathrm{~kg} \mathrm{~m}^{-1} \mathrm{~s}^{-1}$, and the density $\rho_{f}$ is $965 \mathrm{~kg} \mathrm{~m}^{-3}$ (Smits, 2000). The acceleration due to gravity $g$ is $9.81 \mathrm{~m} \mathrm{~s}^{-2}$. The excess fluid pressure $p_{e}$ is assumed equal to the average in-situ tensile strength, $T_{0}=3 \mathrm{MPa}$ (Gudmundsson, 2011a), and to have the potential to drive the water up to the basin surface so that the pressure gradient is $\partial p_{e} / \partial D=-1000 \mathrm{~Pa} \mathrm{~m}^{-1}$. Substituting these values into Eq. (1), the volumetric flow rate $Q_{D}^{s}$ in a rigid host rock is $1.4 \mathrm{x}$ $10^{-3} \mathrm{~m}^{3} \mathrm{~s}^{-1}$. Eq. (2) for the volumetric flow rate $Q_{D}^{e}$ in an elastic host rock, however, with the host rock density $\rho_{r}$ taken as $2400 \mathrm{~kg} \mathrm{~m}^{-3}$, yields $2.0 \times 10^{-3} \mathrm{~m}^{3} \mathrm{~s}^{-1}$. Buoyancy thus increases the total volumetric flow rate through the fracture by a factor of more than 1.4.

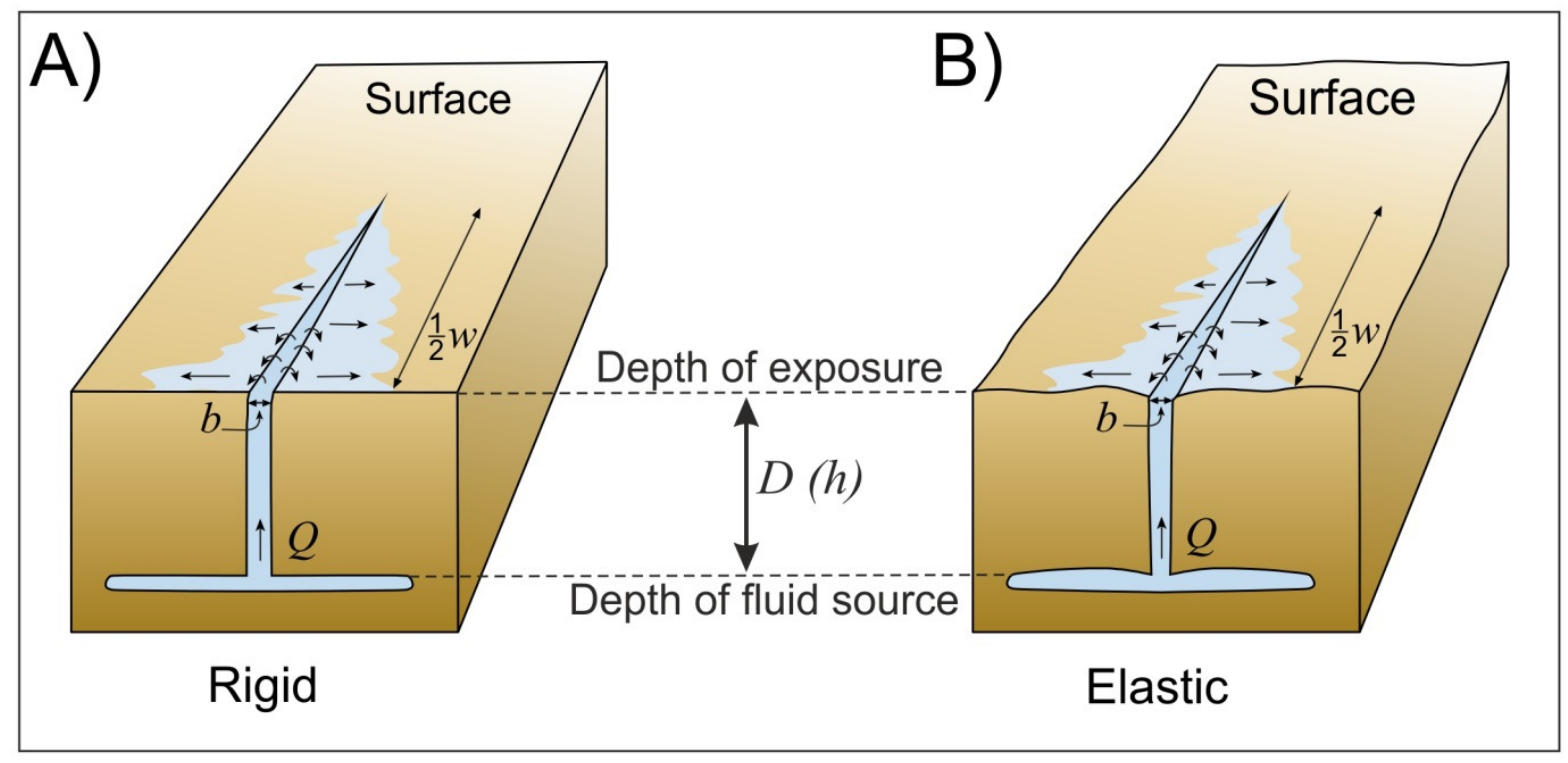

Figure 9.5: Schematic model of a vertical hydrofracture initiated from a horizontal sill below the present exposure at a depth $h$ below the present exposure. $h$ is the height of a fracture, which for a vertical fracture is equal to its dip dimension $D$ along which fluid flow $Q$ takes place. $W$ is the width of the fracture perpendicular to the flow direction. For a vertical through-going fracture $W$ is equal to its outcrop length $L . b$ is the fracture aperture in an outcrop; A) In a rigid host rock, the fracture and the sill are self-supporting and the shape of a hydrofracture does not depend on its fluid pressure; B) In an elastic host rock, the shape of a hydrofracture depends on its fluid overpressure, the fracture and the sill deform during fluid transport, and buoyancy has to be taken into account. 
The most critical parameter in these calculations, however, is the fracture aperture $b$, since its cube enters Eqs. (1) and (2).

For a fracture with an aperture $b$ of only $0.1 \mathrm{~mm}$ (one tenth of the previous example), and all other parameters as given above, $Q_{D}^{s}$ is $1.4 \times 10^{-6} \mathrm{~m}^{3} \mathrm{~s}^{-1}-$ one thousandth of that of the first example. This indicates that even few fractures with large apertures in a set consisting of tens or hundreds of fractures may completely control the fluid flow through that set.

Fluid flow in a fractured reservoir is largely, and may be almost entirely, controlled by the permeability of its fracture network (Figs 9.6, 9.7). As an extreme case, if a reservoir consists of a completely impermeable rock except for a fracture network, fluid flow could occur only along the fractures irrespective of the hydraulic gradient. No large-scale flow, however, takes place along a particular fracture network unless the fractures are interconnected.

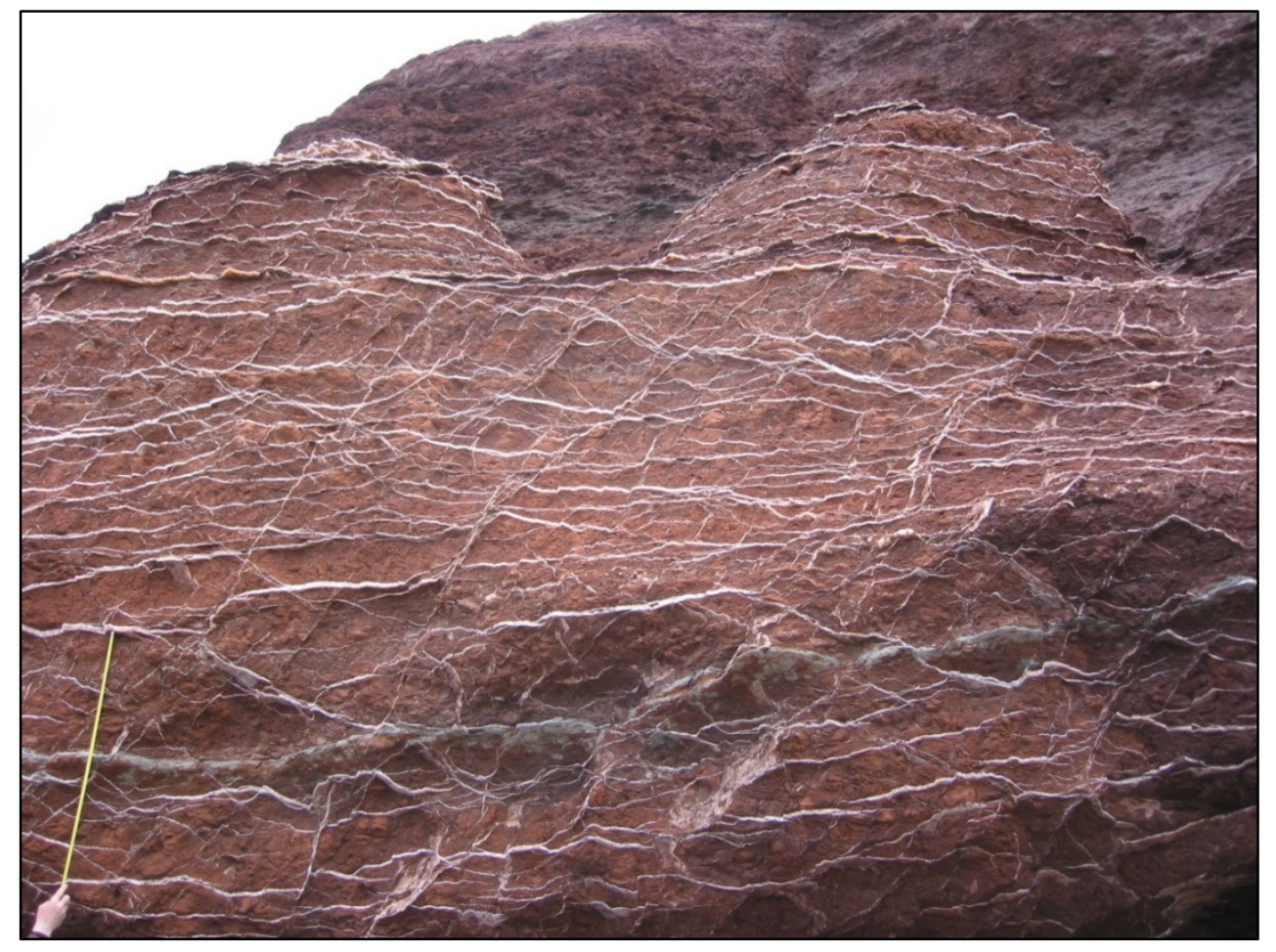

Figure 9.6: In comparatively homogeneous rocks, such as these thick mudstones at Watchet, Somerset coast, Southwest England (cf. Philipp, 2008), there may develop interconnected networks of mineral veins (here of gypsum) or other hydrofractures mudstones commonly have a very low permeability, but such well-interconnected networks of hydrofractures may generate a high temporary permeability. View east; the measuring steel tape is $1 \mathrm{~m}$ long.

For fluid flow to occur from one site to another there must be at least one interconnected cluster of fractures that links these sites (Fig. 9.6). The condition that such a cluster exists is commonly referred to as the percolation threshold (Stauffer and Aharônî, 1994). Fractures 
that are restricted to single layers (Fig. 9.7) normally have a lower probability of being interconnected with other fractures than fractures that dissect many layers (e.g. Priest, 1992) and thus often do not contribute significantly to permeability in reservoirs. Fractures restricted to single layers are referred to as stratabound or layerbound, whereas for non-stratabound fractures, layering does not affect fracture growth (Odling et al., 1999; Gillespie et al., 2001).

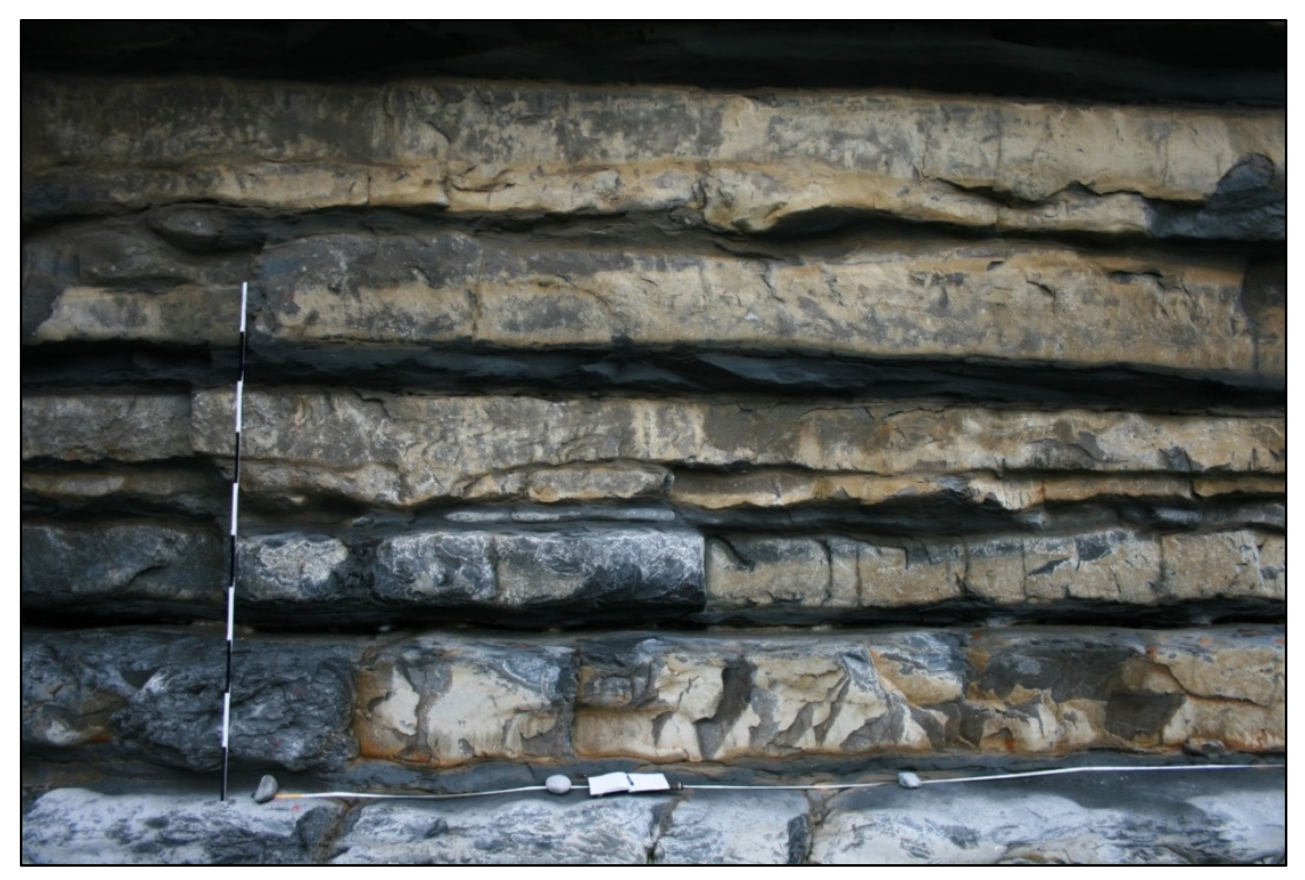

Figure 9.7: In mechanically layered rocks, such as this succession of limestone and shale at Nash Point, Glamorgan coast, South Wales, many fractures, such as these joints, become restricted to certain layers. The joints presumably became arrested when their tips tried to propagate from the stiffer limestone layers into the much softer shale layers. Arrested fractures contribute significantly less to the overall permeability of a fluid reservoir than do fractures that propagate through many layers, since they are less likely to develop interconnected fracture systems that reach the percolation threshold. View east; the measuring steel tape is $2 \mathrm{~m}$ long.

\subsubsection{Fluid transport in faults}

'Deformed fractures' in the definition of Nelson (1985) are primarily shear fractures, that is, faults. Faults have strong effects on permeability (Barton et al., 1995; Finkbeiner et al., 1997; Gudmundsson, 2000a). They can be sealing (Jones et al., 2008), but they are commonly major water conduits (Bruhn et al., 1994; Caine et al., 1996; Evans et al., 1997; Haneberg et al., 1999; Faybishenko et al., 2000). Fault zones normally consist of two major hydrogeological units (Chester and Logan, 1986; Faulkner et al., 2010): a fault core and a fault damage zone. 
The core consists primarily of breccia, gouge and other cataclastic rocks; the damage zone is characterised by fractures of various sizes (Bruhn et al., 1994; Caine et al., 1996; Sibson, 1996; Evans et al., 1997).

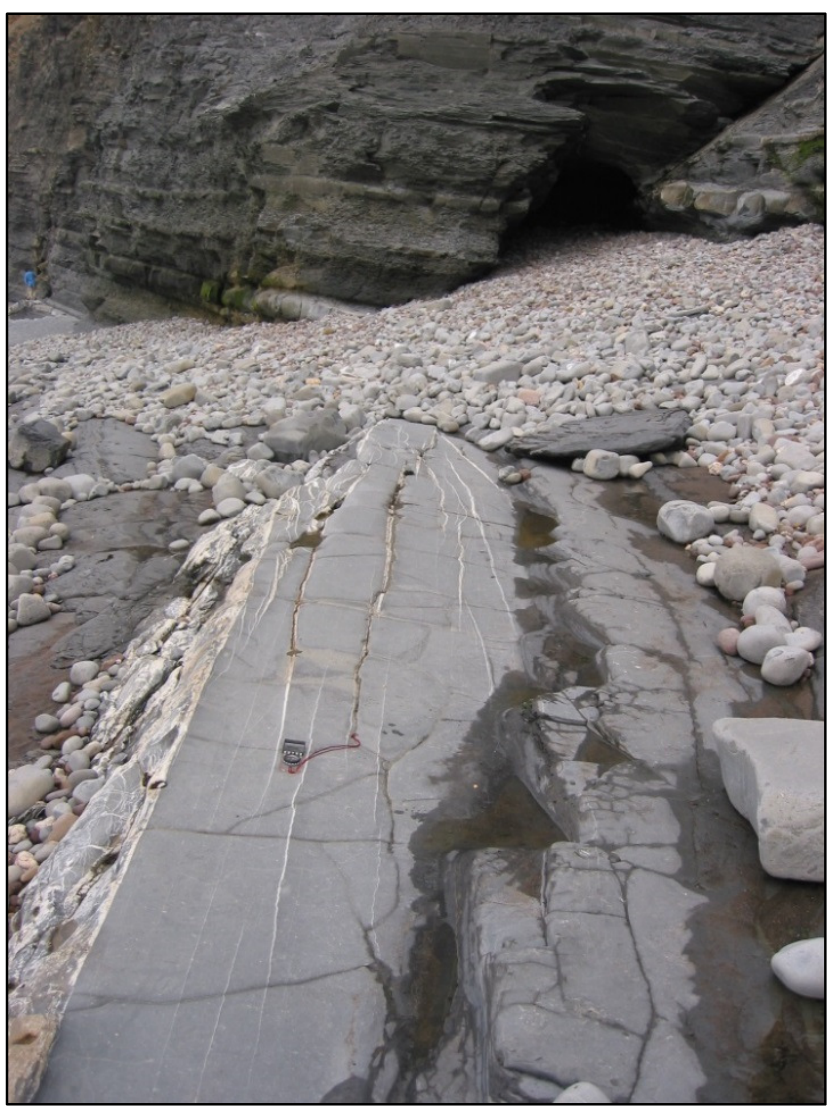

Figure 9.8: View along strike of a normal fault at Kilve, Somerset coast, Southwest England (cf. Philipp, 2012). There is a dense network of calcite veins running subparallel to the fault plane. The veins extend for a distance of only a few meters away from the fault plane into the damage zone. For the veins in the foreground that are continuous non-restrictive, and undeformed extension fractures and for which both ends are visible in the outcrop, the outcrop length/aperture (thickness) ratios can be measured, so that the fluid overpressure at the time of hydrofracture formation (cf. Fig. 9.9) can be estimated using Eq. (5). View east; see the compass for scale.

For example, in a Liassic limestone-shale succession in England, calcite veins occur almost exclusively in the damage zones and the cores of normal faults, indicating that the fault planes transported the fluids that formed the veins (Fig. 9.8). Some veins were clearly injected into the limestone layers of the damage zone directly from the fault plane (Brenner, 2003; Brenner
Active faults commonly have great effects on the transport of crustal fluids (Gudmundsson, 2000a). For groundwater, for example, the effects of fault slip during earthquakes include changes in yield of springs, water table and stream flow (Roeloffs, 1988; Muirwood and King, 1993; Rojstaczer et al., 1995; King et al., 1999; Grecksch et al., 1999). Similar effects occur in hydrothermal systems. During fault slip all the pores and small fractures that meet with the slip plane become interconnected so that the fault develops temporarily a high hydraulic conductivity (Gudmundsson, 2000a). When active, a fault plane with an aperture of less than $1 \mathrm{~mm}$ is able to transport more water than a $100 \mathrm{~m}$ thick porous layer of average hydraulic conductivity of $10^{7} \mathrm{~ms}^{-1}$ (Lee and Farmer, 1993; Gudmundsson, 2000a).

The best evidence of former fluid transport paths, particularly in deeply eroded, inactive fault zones, are networks of mineral veins (McCaffrey et al., 1999; Gudmundsson et al., 2002). 
and Gudmundsson, 2004a; Gudmundsson et al., 2010). Many inactive faults are of low permeability and even act as seals for fluids, particularly if they develop clay smear along their planes. Fault planes in sedimentary basins, however, tend to be planes of weakness. Overpressured fluids that flow into such planes are likely to follow the fault planes to higher stratigraphic levels as hydrofractures. These hydrofractures may then be injected into the rocks in the damage zone of the fault zone and build interconnected fracture networks.

The current stress field also controls fluid flow in, and therefore the permeability of, fractured reservoirs (Heffer et al., 1997; Faybishenko et al., 2000; Gudmundsson, 2000b; Smart et al., 2001). One reason for this is that fractures are sensitive to changes in the stress field and deform much more easily than circular pores. In a fault zone where most fractures in the damage zone are subparallel to the main fault plane the effect of the current stress field on permeability can be strong. In a stress field where the maximum principal compressive stress is perpendicular to the trend of the fractures, many fractures will be closed and fluid flow inhibited. In a stress field where the maximum principal compressive is parallel with the fracture trend, however, fractures tend to be opened up and fluid transport is enhanced (e.g. Finkbeiner et al., 1997; Twiss and Moores, 2006). Another reason for the control of the current stress field on fluid transport is that faults may be more permeable when they are critically stressed, that is, close to slip in an earthquake (Barton et al., 1995). A third reason is that the stress field contributes to the fluid overpressure of hydrofractures.

\subsection{Hydrofracture emplacement}

\subsubsection{Hydrofracture initiation}

For a hydrofracture to be able to transport fluids, the fracture must be initiated at its source and then propagate for the eventual distance of fluid transport. Fracture initiation depends on the stress conditions at the source (see below; Eq. 3), whereas fracture propagation depends on the stress conditions at the fracture tip (see subchapter 9.3.2 for details). For dykes and sheets, the sources are magma chambers; for subvertical mineral veins and joints likely sources include subhorizontal water sills (Sun, 1969; Fyfe et al., 1978). Such a fluid sill does not necessarily consist only of fluids but is rather a zone of accumulation of fluids which may mainly occupy the pores, as is common in sedimentary rocks. Fluid source is here used in the sense of a fluid accumulation zone with high fluid pressure (e.g. Osborne and Swarbrick, 1997) where a hydrofracture originates. 
Hydrofractures normally initiate when the total fluid pressure $p_{f}$ becomes equal to the sum of the minimum principal stress $\sigma_{3}$ in the roof of the source and in-situ tensile strength $T_{0}$ of the rock in the roof so that the roof ruptures in extension, namely (Gudmundsson et al., 2002):

$$
p_{f}=p_{l}+p_{e}=\sigma_{3}+T_{0}
$$

where $p_{l}$ is the lithostatic stress at the depth of the fluid source. This is equivalent to that the internal fluid excess pressure $p_{e}$ (the pressure in excess of the minimum principal compressive stress; Fig. 9.9) reaches the local in-situ tensile strength. Excess pressure can be generated by several mechanisms. For example, artesian aquifers and petroleum reservoirs may be highly pressured due to impermeable seals and the buoyancy of the fluids (de Marsily, 1986; Chilingar et al., 2002; Deming, 2002). Alternatively, tectonic stresses, such as horizontal tension parallel to the fluid reservoir, or stresses related to active faulting, may reduce one of the horizontal principal stresses leading to the rupture of the reservoir roof (cf. Gudmundsson, 2006). Also, in low-permeability rocks fluid excess pressure may build up locally during mineral transitions (Philipp, 2008).

\subsubsection{Hydrofracture propagation}

Hydrofractures propagate by advancing their tips when the associated tensile stresses exceed the tensile strength of the host rock (this criterion can also be formulated using fracture toughness rather than tensile strength) (e.g. Valko and Economides, 1995). Propagating hydrofractures form their paths by gradually linking up discontinuities in the host rock ahead of their tips into which the fluids subsequently flow. A discontinuity is any significant mechanical break or fracture of low or zero tensile strength in the rock (Priest, 1992). Thus, the stress fields in combination with the discontinuities ahead of a hydrofracture tip largely determine the fracture-propagation path. Favorably oriented discontinuities ahead of the tip open up when they are subject to tensile stresses that exceed their tensile strengths.

Numerical models (e.g. Gudmundsson, 2006; Gudmundsson and Brenner, 2001; 2005; Brenner, 2003; Gudmundsson and Philipp, 2006) show that the maximum concentration of the maximum principal tensile stress (minimum principal compressive stress), $\sigma_{3}$, occurs at the margins of fluid reservoirs and decreases rapidly with distance from the reservoir (cf. Savin, 1961). This indicates that, commonly, the conditions of hydrofracture initiation and 
propagation are satisfied at the margin, and in the vicinity of, the reservoir, whereas at greater distances from the reservoir the stress conditions favor hydrofracture arrest. Consequently, the intensity of hydrofractures injected from a fluid reservoir should normally decrease away from the reservoir, the propagation direction being radially away from the reservoir, in agreement with observations of sheet and dyke swarms (Gudmundsson, 2006).

\subsubsection{Fluid overpressure of hydrofractures}

The term excess pressure refers to the pressure in excess of the minimum principal compressive stress $\sigma_{3}$ or, for a lithostatic state of stress, the overburden pressure in the reservoir roof. Outside the reservoir, in a propagating hydrofracture (Fig. 9.9A), the fluid pressure in excess of the normal stress on the fracture plane, which for extension fractures is the minimum principal compressive stress, $\sigma_{3}$, is referred to as overpressure $p_{o}$. Thus, $p_{o}$ is the pressure available to drive the fracture walls open at a particular point. The term 'overpressure' in the sense used here is well established in the technical literature (Heimpel and Olson, 1994; Bonafede and Rivalta, 1999a; b). However, $p_{o}$ is also referred to as driving pressure or driving stress (Pollard and Segall, 1987; Vermilye and Scholz, 1995; Dahm et al., 2010), or as net pressure (Valko and Economides, 1995). Fluid overpressure, as defined here, is not to be confused with an abnormal pore formation pressure. Such confusion may occur because in part of the literature the hydrostatic pressure is regarded as normal, a lower formation pressure is referred to as subnormal, and a higher formation pressure as supernormal (Selley, 1998) or overpressure (Hubbert and Rubey, 1959; Chapman, 1981; Dahlberg, 1994; Chilingar et al., 2002).

In higher stratigraphic levels hydrofractures commonly develop a fluid overpressure $p_{o}$ due to the buoyancy effect if host rock and fluid have different densities (Fig. 9.9B; Spence et al., 1987; Rubin, 1995; Ray et al., 2007; Geshi et al., 2010; Gudmundsson et al., 2012). This overpressure $p_{o}$ depends on the excess pressure $p_{e}$ in the source, the buoyancy term $\left(\rho_{r}-\rho_{f}\right)$, and the differential stress $\sigma_{d}$ (the difference between the principal stresses $\sigma_{1}-\sigma_{3}$ ) in the host rock at the depth under consideration (for example, an exposure of a mineral vein), thus:

$$
p_{o}=p_{e}+\left(\rho_{r}-\rho_{f}\right) g h+\sigma_{d}
$$

where $h$ is the height of the hydrofracture above the fluid source (Fig. 9.5) and the other parameters are as defined in Eqs. (1) to (3). For water in a sedimentary basin, the buoyancy 
term $\left(\rho_{r}-\rho_{f}\right)$ is always positive and $h$ is zero in the roof of the fluid source and increases upwards, that is, on approaching the Earth's surface.

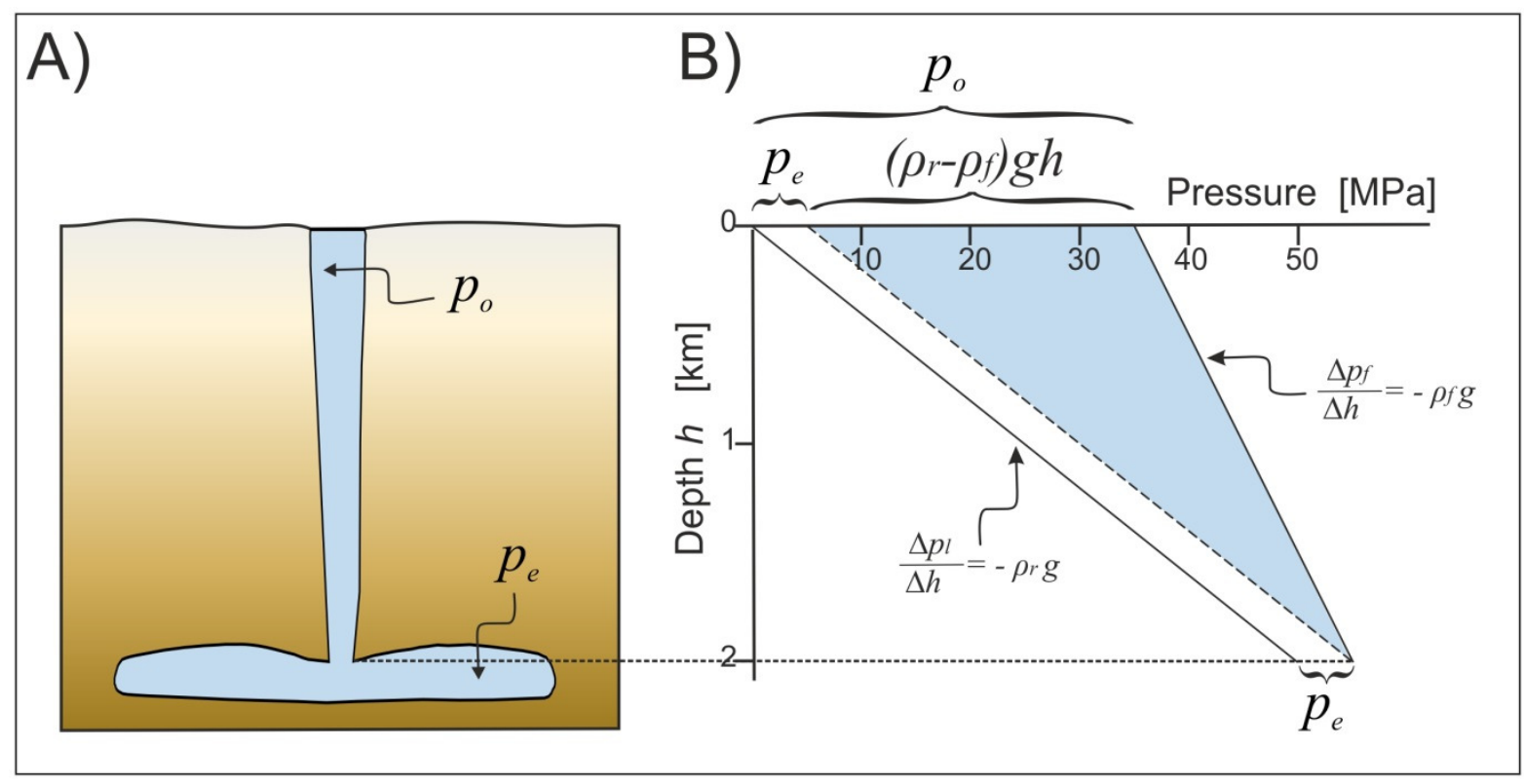

Figure 9.9: A) In an elastic crust (cf. Fig. 9.5), the weight of the rock above the source is supported by the fluid pressure in the source. In the roof of the source, a lithostatic state of stress is assumed, that is, $p_{l}=\sigma_{1}=\sigma_{2}=\sigma_{3}$. In the fluid source an internal fluid excess pressure $p_{e}$ may occur (in excess of the lithostatic stress), and if $p_{e}$ reaches the local in-situ tensile strength $T_{0}$ of the rock in the roof, the fluid source ruptures and a hydrofracture is initiated (Eq. 3). In the propagating hydrofracture, the fluid pressure in excess of the normal stress on the fracture plane, which for extension fractures is the minimum principal compressive stress, $\sigma_{3}$, is referred to as overpressure $p_{o}$; B) Illustration of the buoyancy effect that leads to the fluid overpressure $p_{o}$ in the hydrofracture being different from the excess pressure $p_{e}$ because the density of the host rock, $\rho_{r}$, is different from that of the fluid, $\rho_{f}$. In the roof of the fluid source the total fluid pressure $p_{f}$ at the time of rupture is equal to the sum of the lithostatic stress $p_{l}$ and the excess pressure $p_{e}$ (Eq. 3). Assuming a fluid density $p_{f}$ of $1000 \mathrm{~kg} \mathrm{~m}^{-3}$ (water), according to the weight gradient

$$
\frac{\Delta p_{f}}{\Delta h}=-\rho_{f} g
$$

the fluid pressure inside the hydrofracture decreases upwards with roughly $10 \mathrm{MPa} \mathrm{km}^{-1}$. The lithostatic stress $p_{l}$ in the host rock, however, decreases according to the equation

$$
\frac{\Delta p_{l}}{\Delta h}=-\rho_{r} g
$$

and must be zero at the Earth's surface. Assuming a host rock density $\rho$ r of $2500 \mathrm{~kg} \mathrm{~m}^{-3}$ (average sedimentary rock), the gradient is roughly $25 \mathrm{MPa} \mathrm{km}{ }^{-1}$. If the fluid reservoir is located at $2 \mathrm{~km}$ depth, the lithostatic stress in the roof of the fluid source is $50 \mathrm{MPa}$, and the fluid overpressure $p_{o}$ at the surface is therefore $35 \mathrm{MPa}$. This overpressure $p_{o}$ depends on the excess pressure $p_{e}$ in the source (here assumed to be $5 \mathrm{MPa}$ ), and the buoyancy term $\left(\rho_{r}-\rho_{f}\right) \mathrm{g} \mathrm{h}$. The differential stress $\sigma_{d}$ (Eq. 4) is not illustrated here. The size of the shaded area in the diagram indicates that the buoyancy effect increases upwards, so that the hydrofracture aperture also increases upwards, as is indicated in A). 
It follows, since both $\left(\rho_{r}-p_{f}\right)$ and $h$ are positive, that the buoyancy increases upwards, that is towards the Earth's surface. Consequently, the overpressure $p_{o}$ in a hydrofracture increases upwards away from the reservoir and reaches its maximum value at the surface (Fig. 9.9B). For magma in a dyke, the buoyancy term may become negative when the dyke propagated through low-density rocks, so that the overpressure may approach zero, but for water the buoyancy effect and the overpressure always increase right up to the surface.

The fluid overpressure at the time of formation of paleohydrofractures, such as mineral veins and dykes, can be estimated using physical principles that relate fluid pressures to the fracture aspect (length/aperture) ratios. A subvertical hydrofracture extending from a fluid reservoir to an open contact between layers (or to the surface) can be modeled as a through crack (Fig. 9.3). The fracture height can then be considered infinite and thus the outcrop length is the shorter, controlling, dimension. For a fluid-filled extension fracture modeled as a through crack with outcrop length $L$ and maximum aperture $b_{\max }$, the static overpressure $p_{o}$ is given by (Sneddon and Lowengrub, 1969; Gudmundsson, 2000b):

$$
p_{o}=\frac{b_{\max } E}{2 L\left(1-v^{2}\right)}
$$

where $E$ is Young's modulus and $v$ Poisson's ratio of the host rock.

Rearranging Eq. (4), the fluid overpressure calculated from Eq. (5) can be used to estimate the height of the hydrofracture, that is, the depth $h$ to the fluid source below the present outcrop (Fig. 9.9; Gudmundsson, 1999):

$$
h=\frac{p_{o}-\left(p_{e}+\sigma_{d}\right)}{\left(\rho_{r}-\rho_{f}\right) g}
$$

where all the parameters are as defined above (cf. Becerril et al., 2013).

As an example, we use these analytical models to estimate the fluid overpressure at the time of vein formation for 239 calcite veins in Liassic limestone layers associated with normal faults in England (Fig. 9.8). The outcrop length $L$ and aperture $b$ of these veins have a reasonable linear correlation with an aspect (length/aperture) ratio of 451 (Philipp, 2012). First, however, the mechanical properties of limestone at the time (presumably Cretaceous) and depth $(\sim 1-2 \mathrm{~km})$ of vein formation have to be estimated. Because the limestones were 
young at the time of vein formation and in-situ values are normally lower than laboratory values, Young's modulus is likely to have been in the lower range of typical laboratory values for limestone (10-80 GPa; Bell, 2000); $\mathrm{E}=15 \mathrm{GPa}$ is a reasonable value. Using 0.25 for Poisson's ratio, a common value for limestones (Jumikis, 1979; Bell, 2000; Gudmundsson, 2011a), Eq. (5) gives the average fluid overpressure $p_{o}$ as $18 \mathrm{MPa}$ (cf. Philipp, 2012).

In Eq. (6) we use the limestone density of $2400 \mathrm{~kg} \mathrm{~m}^{-3}$ (Bell, 2000) for $\rho_{r}$ and the water density (for water at $90^{\circ} \mathrm{C}$ ) of $965 \mathrm{~kg} \mathrm{~m}^{-3}$ (Smits, 2000) for $\rho_{f .} p_{e}$ is equal to local in-situ tensile strength $T_{0}$ (Eq. 3) and $\sigma_{d}$ normally cannot be greater than $4 T_{0}$ (Gudmundsson et al., 2002). Common in-situ tensile strengths $T_{0}$ of solid rocks are 0.5-6 $\mathrm{MPa}$, most frequently 2-3 MPa (Haimson and Rummel, 1982; Schultz, 1995; Amadei and Stephansson, 1997). Using these values, Eq. (6) gives the depth of the water source from 213 to $568 \mathrm{~m}$. Using extreme variations of all the included parameters yields a maximum depth of $1200 \mathrm{~m}$ (cf. Philipp, 2012) which is in agreement with oxygen and carbon isotope data indicating fluid sources of the veins $20-30^{\circ} \mathrm{C}$ hotter than the host rocks (Davison, 1995). For 384 quartz veins in basalt in a fault zone in North Iceland, the average aspect ratio is 400; the average overpressure is then estimated at $20 \mathrm{MPa}$ and the depth calculated as being in a similar range as for the example from England (Gudmundsson et al., 2002). This indicates that in both cases, the geothermal water that formed these veins accumulated in sources at shallow depths and was thus of a rather local origin.

\subsubsection{Hydrofracture tip stresses}

To calculate the tip stresses of a rock fracture in general, and a hydrofracture in particular, two approaches have normally been used (Jaeger and Cook, 1979). One is to use a mathematical crack of zero thickness, an approach frequently used in fracture mechanics (Fig. 9.10A; Sneddon and Lowengrub, 1969; Maugis, 2000). The other principal approach in modeling rock fractures is to consider the crack as a flat elliptical hole (Fig. 9.10B; Savin, 1961; Maugis, 2000). This approach is more common in rock mechanics.

A mathematical crack (Fig. 9.10A) is an appropriate model for many hydrofractures, particularly those that initiate as narrow cracks with very thin, hair-like tips; for example many joints (cf. Kusumoto et al., 2013a; b). A hydrofracture located on the vertical $y$-axis is defined by $x=0,-a \leq y \leq a$. The internal fluid overpressure (also referred to as driving pressure or net pressure) of the hydrofracture is given by the even function $p(x)=p(-x)$, so that the pressure is the same on the walls to the left and to the right of the vertical y-axis. For 
a constant overpressure $p(x)=-p_{o}$, so that inside the fracture, for $0 \leq y \leq a, \sigma_{3}=p_{o}$. Beyond the fracture tips, for $y>a$, the crack-tip tensile stress $\sigma_{3}(\mathrm{y}, 0)$ is (Maugis, 2000):

$$
\sigma_{3}=-p_{0} y\left[\frac{1}{\left(y^{2}-a^{2}\right)^{1 / 2}}-\frac{1}{y}\right]
$$

This indicates that when the hydrofracture tip is approached from outside, $y \rightarrow a$, the principal stress $\sigma_{3}$ becomes infinite. Similar solutions are obtained if the overpressure is not constant but varies linearly or by another mathematical law. In nature, however, a crack-tip process or damage zone, plastic flow and, for hydrofractures, a near-tip underpressured zone make the tip stresses finite (Valko and Economides, 1995).

The elliptical hole with a major axis $2 a$ and a minor axis $2 c$ (so that $2 c=b$ is its aperture; Fig. 9.10B) is an appropriate model for many types of fractures. As regards fracture morphology, these include many open fractures, mineral veins and vuggy fractures. In addition, an elliptical hole is often a reasonable model for some tension fractures in rift zones, as well as for many hydrofractures such as dykes, sills and inclined sheets (e.g. Gudmundsson, 2000b). The minimum principal stress $\sigma_{3}$ at the tips of an elliptical hole subject to a fluid overpressure $p_{o}$ is (Peterson, 1974; Maugis, 2000):

$$
\sigma_{3}=-p_{o}\left[\frac{2 a}{c}-1\right]
$$

As an example, we calculate the tip tensile stresses for the calcite veins presented above (see subchapter 9.3.3 for details). With an aspect ratio $a / c=451$ and an estimated fluid overpressure of $p_{o}=18 \mathrm{MPa}$, Eq. (8) yields an average crack-tip tensile stress of $\sim 1.6 \times 10^{4}$ $\mathrm{MPa}$. Using common aspect ratios of regional dykes, measured in lateral sections in Iceland, as 900-1000, and their estimated overpressures as several tens of megapascals (Gudmundsson, 2006), we obtain $\sigma_{3}$ at a lateral dyke tip as $\sim 10^{4} \mathrm{MPa}$, the same order of magnitude as for the mineral veins.

To explore stress fields affecting hydrofracture propagation we have run many numerical models (cf. e.g. Brenner and Gudmundsson, 2002; 2004a; b; Gudmundsson and Brenner, 2001; 2005; Gudmundsson and Philipp, 2006). Here we present boundary-element models 
(Brebbia and Dominguez, 1992) using the program BEASY (www.beasy.com) that are similar to previously published models to illustrate and explain better the results presented here.

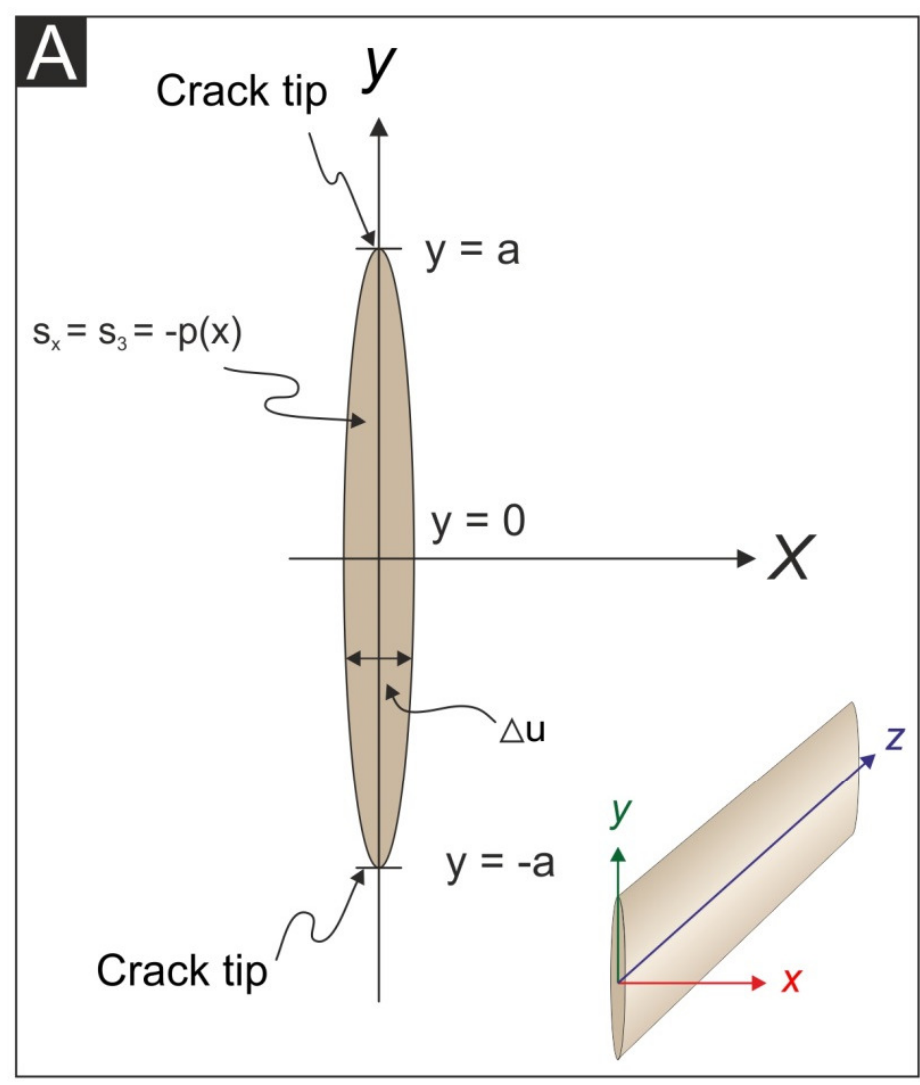

\section{$\mathrm{B}$}

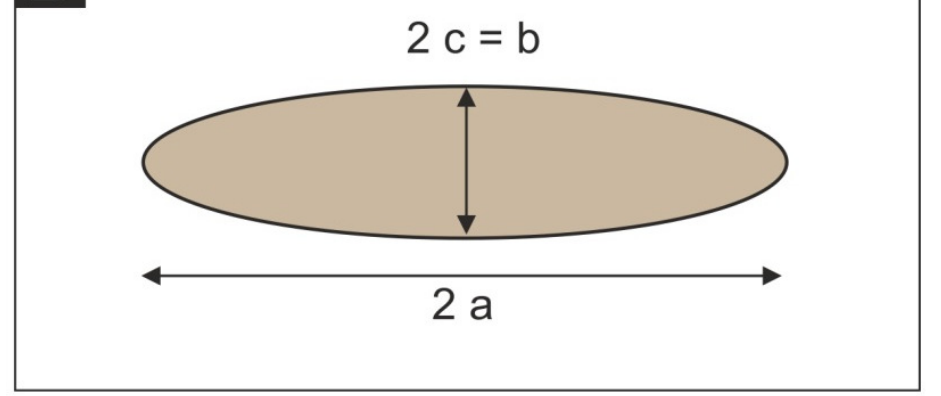

Figure 9.10: A) Schematic illustration of a mathematical crack as a fracture representation. The crack has a length $2 \mathrm{a}$ along the $\mathrm{y}$-axis and its opening displacement $\Delta u$ depends on the fluid overpressure inside the fracture. At the crack tips, the crack-tip tensile stresses become infinite (Eq. (7)); B) Schematic sketch of an elliptical hole with a minor axis $2 c=b$ and a major axis 2a. The crack-tip tensile stress is calculated with Eq. (8).
As for many three-dimensional problems, one dimension can be considered as effectively infinite so that the problem can be modeled in two dimensions, using specific equations for the condition referred to as plane strain (one principal strain is zero; Jaeger and Cook, 1979). All models are scale-independent so that the results can be used for any size of hydrofracture.

First we explore the tensile stress at a hydrofracture tip in a homogeneous, isotropic rock (Fig. 9.11), where a hydrofracture subject to a constant fluid overpressure of $10 \mathrm{MPa}$ is located in a crust with Young's modulus $100 \mathrm{GPa}$ and Poisson's ratio of 0.25. The model is three units high and six units wide. The units used here are arbitrary measures of distance and primarily to indicate the aspect (height/width) ratio of the model and the related size and depth of the hydrofracture. In the model, the hydrofracture tip is at 0.5 units below the surface so that the 
fracture half-length $a$ is 2.5 units; the initial (undeformed) thickness $b$ of the hydrofracture is 0.04 units. This fracture has the shape of a rhombus, not of an ellipse, so that Eq. (8) cannot be used to obtain its tip stress. In nature, the dip dimension (height) of such a hydrofracture could be in the order of tens or hundreds of meters. Since fluid overpressure is the total fluid pressure minus the stress normal to the fracture, remote tension or compression (e.g. due to gravity) is automatically included in the loading conditions for the layer hosting the fracture (Gudmundsson et al., 2012; Kusumoto et al., 2013a; b). To avoid rigid body translation and rotation, the model needs to be fastened (using the condition of no displacement). In order to allow the hydrofracture to deform freely, however, the model is fastened in the lower corners only.

The magnitude of the tensile stress around the hydrofracture tip is shown in Figure 9.11A as contours of the minimum principal compressive (maximum principal tensile) stress $\sigma_{3}$ in megapascals ( $\mathrm{MPa}$; truncated at $1 \mathrm{MPa}$ and $10 \mathrm{MPa}$ ). The maximum calculated tensile stress at the fracture tip is $149 \mathrm{MPa}$ (Fig. 9.11B), and there is a large area around the fracture tip where the tensile stress exceeds $10 \mathrm{MPa}$ (Fig. 9.11A). The tensile stress then falls off quickly with distance from the fracture tip (Fig. 9.11B). At the surface directly above the fracture tip, no tensile stresses occur, but the tensile stress concentration at the surface has two peaks (Fig. 9.11C). This is similar to analytical solutions for vertical extension fractures in a homogeneous, isotropic elastic half space subject to remote tensile stresses or internal fluid pressure (Isida, 1955). Since the in-situ tensile strength of common solid rocks varies from 0.5 to $6 \mathrm{MPa}$ (Haimson and Rummel, 1982; Schultz, 1995; Amadei and Stephansson, 1997), the above results from analytical and numerical models indicate that theoretical tip tensile stresses are from one hundred to ten thousand times greater than the tensile strength of the host rock through which these hydrofractures propagate. Similar results follow from other models of hydrofractures in homogeneous, isotropic rocks (Weertman, 1971; Secor and Pollard, 1975).

This indicates that, for a homogeneous and isotropic rock, any significant overpressure in a hydrofracture normally generates very high (and for a mathematical crack, infinite) crack-tip tensile stresses so that any continuous and buoyant hydrofracture should propagate to the earth's surface. Natural rocks, however, are normally heterogeneous and anisotropic and most hydrofractures become arrested at various crustal depths. In mechanically layered rocks, in particular, arrested hydrofractures are common.

This is evidenced by many field observations of dykes, veins and joints and field and laboratory experiments on man-made hydraulic fractures in petroleum engineering. 


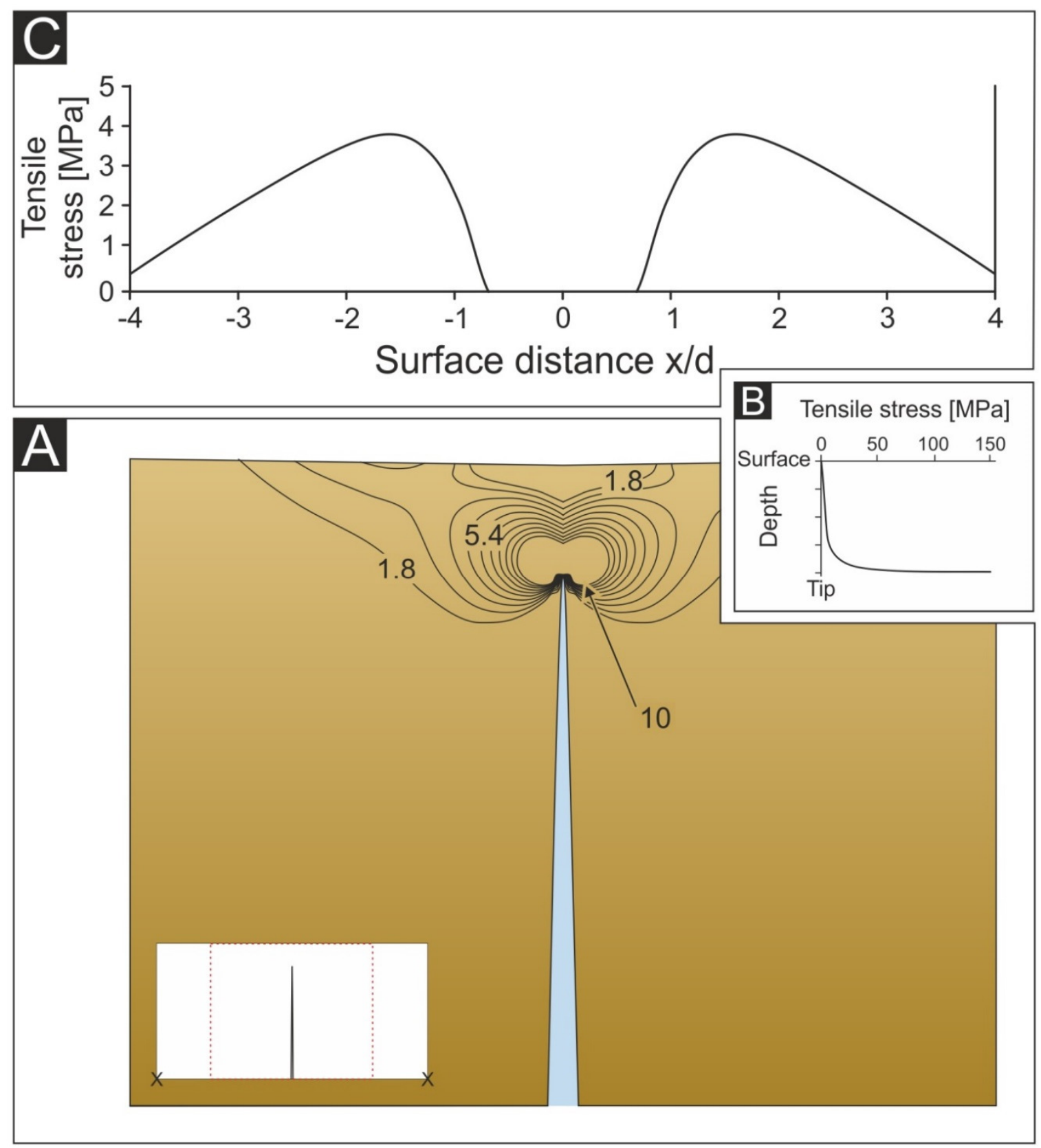

Figure 9.11: Boundary-element model of the tensile stress around a hydrofracture in a homogeneous isotropic crust with Young's modulus $100 \mathrm{GPa}$, Poisson's ratio 0.25. The inset in A) shows the set-up of the model: the model is 3 units high and 6 units wide. The dashed lines indicate the part of the model which is shown on the large results figure. The crosses indicate the boundary conditions of no displacement in the lower corners of the model. The hydrofracture tip is at 0.5 units below the surface; A) Concentration of the maximum tensile principal stress (minimum compressive stress) $\sigma_{3}$, in megapascals (truncated at $1 \mathrm{MPa}$ and $10 \mathrm{MPa}$ ). The aperture of the hydrofracture is shown 150 times exaggerated. In a large area around the fracture tip, tensile stresses exceed $10 \mathrm{MPa}$; B) Tensile stress distribution from the surface to the hydrofracture tip. The tensile stress is zero at the surface, but at the tip, it reaches $149 \mathrm{MPa}$; C) Maximum principal tensile stress at the surface. The tensile stress distribution has a peak of $4 \mathrm{MPa}$ on either side of the fracture tip at a horizontal distance 1.6 times the distance to the hydrofracture tip below the surface ('surface distance'). 
Layering in solid materials in general is known to have strong effects on fracture propagation (e.g. Daniel and Ishai, 1994; Broberg, 1999; Brooks and Choudhury, 2002; Nasseri et al., 2006; Zhang et al., 2007; Tvergaard and Hutchinson, 2008). In the following section we explore hydrofracture emplacement in mechanically layered rocks in detail.

\subsection{Hydrofracture emplacement in mechanically layered rocks}

\subsubsection{Mechanical layering of reservoir rocks}

Layering is a common feature of many heterogeneous rock masses. Layered reservoirs are well known in the field of petroleum engineering (Aguilera, 2000; Economides and Boney, 2000). In that field, a practical distinction is often made between laminated and layered reservoirs in that a reservoir is referred to as layered when the layers are thick enough to be targeted by a horizontal well, but as laminated when the layers are too thin for such a targeting to be possible (Economides and Boney, 2000). Generally, laminated reservoirs have a poor vertical permeability (Economides and Boney, 2000). In layered reservoirs, the permeability from layer to layer can vary considerably. Generally, ignoring the variation in permeability between layers in a reservoir can lead to an overestimate of its overall permeability (Aguilera, 2000).

One main reason why the permeability may vary considerably between rock layers is that some layers host more interconnected fractures than others. In turn, the fracture frequency in a single layer depends on the chances of fracture development in that layer. Since fracture development is mostly controlled by the state of stress in the host rock (Warpinski et al., 1982) which in turn correlates with rock mechanical properties (Hudson and Harrison, 1997), fracture development is largely controlled by the mechanical properties of the layers. In order to understand fracture development in layers that themselves are homogeneous and isotropic (even if the rock as a whole is heterogeneous and anisotropic), at least two elastic constants must be determined. The two constants most commonly used in rock mechanics are Young's modulus and Poisson's ratio (Hudson and Harrison, 1997).

At low temperatures and pressures and up to about $1 \%$ strain, most solid rocks behave approximately as linear elastic materials (Paterson, 1978; Farmer, 1983). This means that Hooke's law (strain varies linearly with stress) is approximately valid and Young's modulus $E$ of that rock can be defined as the ratio of stress to strain. Young's modulus is a measure of the stiffness of the rock and is often referred to as stiffness. Following the tradition in 
engineering rock mechanics, layers with high Young's moduli are referred to as stiff and those with low Young's moduli as soft. As measured in the laboratory, Young's moduli for common bedrocks range from less than $0.1 \mathrm{GPa}$ for some soft sediments and pyroclastic rocks to as much as $130 \mathrm{GPa}$ for some igneous and metamorphic rocks, with the most common values being 1-100 GPa (Hatheway and Kiersch, 1982; Afrouz, 1992; Bell, 2000; Schön, 2004; Gudmundsson, 2011a).

Because hydrofracture propagation is normally slow compared with the velocity of seismic waves (Valko and Economides, 1995), it is appropriate to use static Young's moduli, normally 2 to 10 times lower than the dynamic moduli (Goodman, 1989), for analyses of hydrofractures. Also, in-situ elastic properties are normally different from those measured in the laboratory. In particular, in-situ static Young's moduli tend to be as much as 1.5 to 5 times lower than that measured of the same rock type in the laboratory (Heuze, 1980). This is mainly because fractures in in-situ rock masses lower their stiffnesses whereas the rock samples measured in the laboratory are essentially free of fractures (Goodman, 1989; Priest, 1992; Hudson and Harrison, 1997). With increasing pressure and temperature, and thus with increasing depth in the crust, however, the differences between the laboratory and in-situ values decrease.

Poisson's ratio $v$ is a measure of the absolute ratio of strain in perpendicular directions. The range of Poisson's ratios for bedrocks is, as compared with Young's modulus, narrow. Typical values for solid rocks range from 0.2 to 0.35 with $v=0.25$ being most common (Jumikis, 1979; Jaeger and Cook, 1979; Bell, 2000).

Rock masses where the mechanical properties change between layers are commonly referred to as mechanically layered. Mechanical layering may coincide with changes in grain size, mineral content, or facies. For example, in layered sedimentary reservoirs, such are common in carbonates (limestone interlayered with marl) or siliciclastics (sandstone interlayered with shale or clay), some rock types forming individual layers (such as limestone or sandstone) may be considerably stiffer than other layers (such as marl or clay) (Bell, 2000; Schön, 2004; Gudmundsson 2011a). Also volcanic rocks are commonly mechanically layered, since they often consist of rather stiff lava flows (and sills) and softer volcanic tuffs or other pyroclastic rocks (Bell, 2000). In metamorphic rocks mechanical layering can be observed, for example, in many gneisses where leucosome and melanosome may have different mechanical properties (Hatheway and Kiersch, 1982). However, if a layered rock mass has essentially the same Young's modulus throughout, and if the layers are welded together so that there are no weak or open contacts, the layers may function mechanically as a single layer. 


\subsubsection{Field observations and numerical model on hydrofracture emplacement}

In mechanically layered rocks, the mechanical properties, particularly the Young's moduli, change between layers. In many layered rocks, predominantly in sedimentary and volcanic rocks at shallow depths, the contacts between individual layers are weak (non-welded, the tensile strength across the contact being negligible) or open (cf. Gudmundsson et al., 2002; Gudmundsson, 2006). Some fractures propagate through contacts as collinear fractures (Becker and Gross, 1996), but when a propagating hydrofracture meets with a weak or open contact, such as bedding, or a layer of contrasting mechanical properties, it commonly becomes either arrested (Fig. 9.12) or offset when it continues with a step-over upwards (Fig. 9.13). There are four main mechanisms by which hydrofractures become arrested, or offset: (i) material toughness, (ii) discontinuities, (iii) stress barriers and (iv) changes in rock stiffness (Young's modulus). Since the material toughness mechanism also involves changes in stiffness across a discontinuity (e.g. a contact), mechanisms (i) and (iv) are commonly discussed together and regarded as one. All these mechanisms related to rock layering and discontinuities and all may operate together in a single rock mass during fracture propagation. Material toughness is a well-known concept in materials science (He and Hutchinson, 1989; Kim et al., 2006; Lee et al., 2007). It is the critical strain energy release rate of a layer or the contact between layers. More specifically, material toughness, denoted by $G$ and with the units of $\mathrm{J} \mathrm{m}^{-2}$, is a measure of the energy absorbed in a material (here rock) per unit area of a frature in the material (e.g. Broberg, 1999; Gudmundsson, 2011a). The greater the material toughness of a layered rock mass then, other things being equal, the greater is the (elastic) energy needed to propagate a fracture through that mass. Analytical solutions indicate that the probability of fracture becoming deflected and/or arrested at an interface (e.g. a contact), rather than penetrating the interface, depend on the difference in Young's modulus between the layers on the opposite sides of an interface/discontinuity (e.g. a contact) and the difference in material toughness between the interface itself and the layer on the opposite side (the layer not hosting the fracture) in relation to the energy release rates associated with fracture deflection and penetration. More specifically, if there is no Young's modulus (stiffness) mismatch (no difference in Young's modulus) across the interface, then fracture deflection occurs only if contact toughness is about $25 \%$ of the toughness of the material (here the rock) on the other side of the contact (He and Hutchinson, 1989; Hutchinson and Suo, 1992; Kim et al., 2006; Lee et al., 2007; cf. Gudmundsson et al., 2010; Gudmundsson, 2011a; b). However, when the Young's modulus mismatch increases, deflection will still occur even if the material 
toughness of the interface/contact becomes equal to or higher than the bulk material toughness.

The term 'discontinuity' includes fractures as well as contacts. A 'stress barrier' for a vertical hydrofracture is a layer or discontinuity where the hydrofracture-normal compressive stress is higher than in the adjacent layers; in general, a stress barrier is any layer or contact with unfavorable stress conditions for the propagation of a particular type of a fracture. Stress barriers are particularly common in mechanically layered rocks (Haimson and Rummel, 1982; Amadei and Stephansson, 1997; Zang and Stephansson, 2010). Discontinuities, stress barriers, and changes in rock stiffness are related in that changes in stiffness and stress barriers are common at contacts (discontinuities) between different rock types (Gudmundsson and Brenner, 2001; Brenner, 2003).

An open or weak contact may open up as a fracture tip approaches it, in which case the hydrofracture normally propagates along part of the open contact or becomes arrested. A resulting deflected or $\mathrm{T}$-shaped fracture is commonly observed (or inferred) in fracture mechanics (Cook and Gordon, 1964; Atkins and Mai, 1985; He and Hutchinson, 1989), in petroleum engineering hydraulic fracture studies (Gulrajani and Nolte, 2000; Kim et al., 2006; Zhang et al., 2007), and in volcanic regions where dykes change into sills (Gudmundsson, 2011b). Some fractures are also arrested by slip at contacts (interfaces). There is some field evidence for slickensides along bedding planes in sedimentary rocks (Cooke and Underwood, 2001), and Renshaw and Pollard (1994) propose that when slip occurs, crack-tip tensile stresses cannot be transmitted across the interface so that the tip becomes arrested.

Dykes often end at layer contacts which show no evidence of slip (Gudmundsson, 2006; Gudmundsson and Philipp, 2006). Many dykes, for example in Tenerife (Canary Islands) and Iceland, are arrested at contacts between lava flows and pyroclastic layers (Fig. 9.12A, cf. Gudmundsson and Brenner, 2001; Gudmundsson and Philipp, 2006) or at bedding contacts in sedimentary rocks (Baer, 1991). Some dykes thin gradually towards the discontinuity; others end bluntly (Fig. 9.12A). When there are stress barriers, dykes may end vertically by tapering away in relatively homogeneous and isotropic rock layers (Gudmundsson and Brenner, 2001; Gudmundsson and Philipp, 2006).

Mineral veins may also become arrested at contacts in mechanically layered rocks. For example, in layered carbonate rocks (Gillespie et al., 2001; Gudmundsson and Brenner, 2001; Brenner and Gudmundsson, 2004a; b), most of the calcite veins are confined to limestone layers and end abruptly, some with blunt tips, at the contacts to shale layers (Fig. 9.12B). 

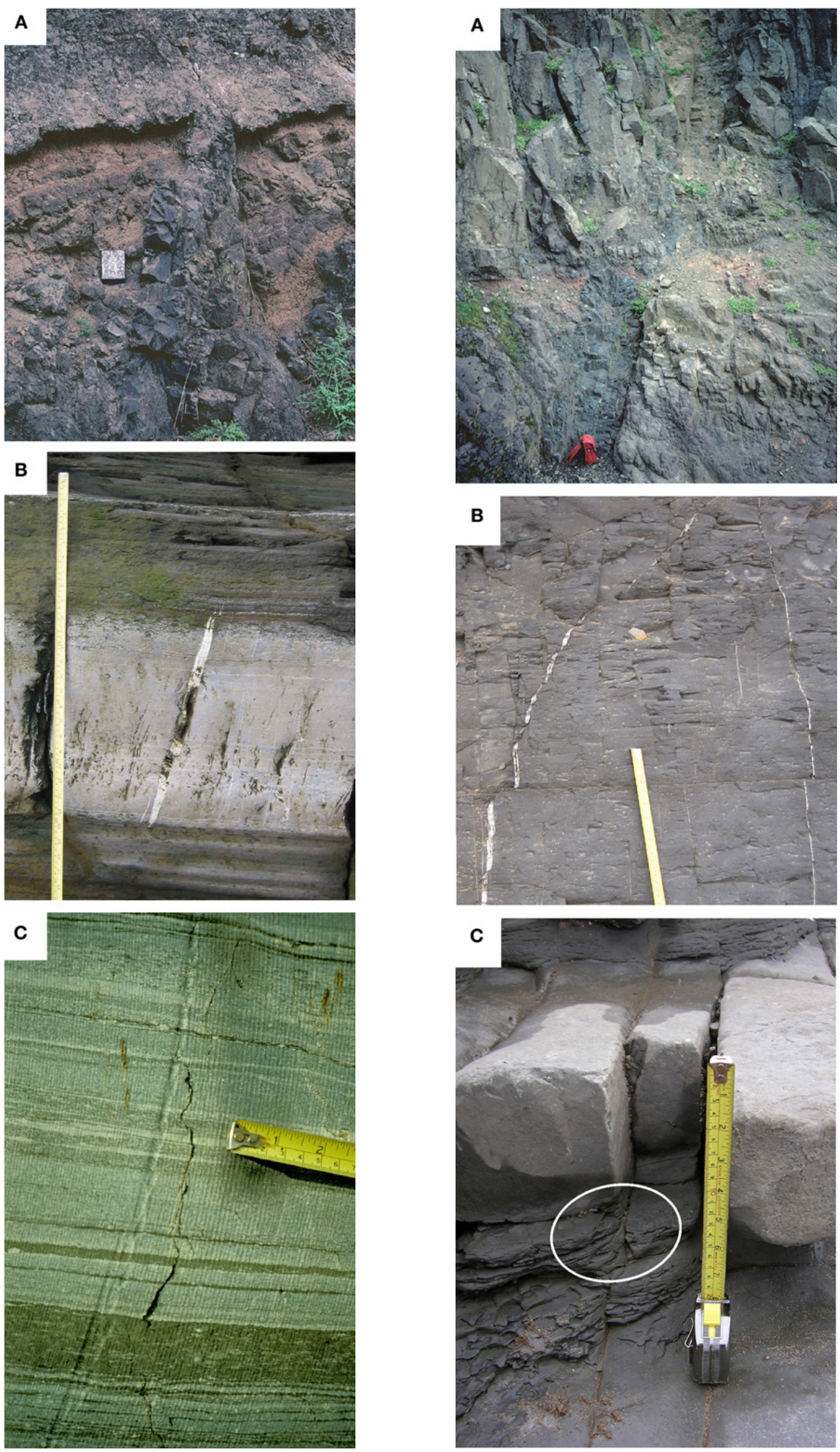
Figure 9.12: Arrested hydrofractures in Figure 9.13: Hydrofractures offset at layered rocks (cf. Brenner, 2003). A) Arrested, blunt dyke tip in a vertical section at a road cut in Tenerife, at the contact between a pyroclastic rock layer below and a basaltic lava flow above. View west; the notebook provides a scale; B) Arrested calcite vein at Kilve, Somerset coast, Southwest England. The vein is arrested at the contacts of a limestone layer to shale layers above and below. View east-southeast; the visible part of the measuring steel tape is $0.5 \mathrm{~m}$ long; C) Arrested open joint in gneiss at a road cut in the city of Bergen, West Norway. The joint is arrested at the contact of leucosome layers to an amphibolitic melanosome layer. View north-northeast; visible part of the measuring steel tape is $0.065 \mathrm{~m}$ long.

contacts (cf. Brenner, 2003). A) Dyke becomes offset on crossing a weak scoria contact between two basaltic lava flows in the paleorift zone of North Iceland. View north; the backpack at the lower dyke segment provides a scale; B) Calcite veins offset at a weak contact between shale layers at Kilve, Somerset coast, Southwest England. View south; the visible part of the measuring steel tape is $0.3 \mathrm{~m}$ long; C) Joint (encircled) becomes offset at a weak contact between shale layers at Nash Point, Glamorgan coast, South Wales. View south; the measuring steel tape is $0.2 \mathrm{~m}$ long.

Commonly joints, many of which are hydrofractures, terminate abruptly on meeting with contacts between layers with contrasting mechanical properties. For example, many joints in layered carbonate rocks are restricted to limestone layers (Gillespie et al., 2001; Brenner and Gudmundsson, 2004a; b; Larsen et al., 2008). Field observations show that there is often no slip at bedding contacts associated with the arrested veins and joints (Brenner and Gudmundsson, 2004a; b; Larsen et al., 2008). Also in gneiss, joints can become arrested at the contact of leucosome layers to melanosome layers (Fig. 9.12C; Brenner and Gudmundsson, 2002).

Hydraulic fractures in petroleum engineering become arrested when their vertical tips enter layers of high fracture-perpendicular compressive stresses or meet with sharp contacts between mechanically contrasting layers (e.g. Daneshy, 1978; Simonson et al., 1978; van Eekelen, 1982; Warpinski et al., 1982; 1987; Teufel and Clark, 1984; Naceur and Touboul, 1990; Valko and Economides, 1995; Charlez, 1997; Yew, 1997; Economides and Nolte, 2000; Zhang et al., 2007).

Offset of hydrofractures is also commonly observed in mechanically layered rocks, particularly when there are weak contacts. Lateral dyke offsets across contacts between layers of contrasting mechanical properties, such as lava flows and pyroclastic rocks (Fig. 9.13A), are very common. In some cases, the individual arrested segments of a dyke are connected by thin, igneous veins across the contacts or the dyke may even follow the contact as a sill before it continues propagating upwards (Gudmundsson and Brenner, 2005; Gudmundsson and 
Philipp, 2006). However, particularly in lateral sections, many dyke segments have no visible connections, that is, the individual segments may look like individual, non-connected fractures in a section, although all dyke segments must be fed by and be connected to a magma chamber (Fig. 9.13A). Also, mineral veins and joints may become offset along contacts. For example, some calcite veins in marly shale layers are offset (with very thin connections between the segments) at bedding contacts (Fig. 9.13B). Similar offsets can be observed for many joints (Fig. 9.13C; Helgeson and Aydin, 1991; Cooke and Underwood, 2001; Rijken and Cooke, 2001; Larsen et al., 2008).

These and other field observations indicate that the arrest or, more generally, offset of hydrofractures at contacts in mechanically layered rocks is very common. One reason why the mechanical properties of rock layers and contacts have such great effects on the propagation and emplacement of hydrofractures is that these mechanical conditions affect the local stress fields in rocks. From Hooke's law (strain varies linearly with stress) it follows that, for a given strain, the stress concentration in a stiff (high Young's modulus) material will be greater than in a soft (low Young's modulus) material. The local stress fields in a rock consisting of stiff and soft layers will thus be very different from the ones in homogenous, isotropic media. A weak contact (or other discontinuity) behaves as a fracture that concentrates and redistributes the local stresses and may contribute to fracture arrest (Warpinski and Teufel, 1987; Weertman, 1996; Gudmundsson and Brenner, 2001; Gudmundsson, 2011a).

Thus the local stress field associated with mechanically layered rocks largely controls whether a hydrofracture meeting a contact between rock layers of contrasting mechanical properties propagates through the contact (with or without an offset) or, alternatively, becomes arrested (Gudmundsson and Brenner, 2005; Zhang et al., 2007). The effects of discontinuities (e.g. Cook and Gordon, 1964; Daneshy, 1978; Cooke and Underwood, 2001) and stress barriers (e.g. Valko and Economides, 1995; Charlez, 1997; Yew, 1997; Smith and Shlyapobersky, 2000) on hydrofracture arrest have received more attention than have changes in rock stiffness.

With a numerical model we explore the stress field around a hydrofracture tip in a mechanically layered crust (Fig. 9.14). A small inset in the illustration indicates the initial, undeformed geometry of the model. The model is similar to the model in Figure 9.11 but the crust consists here of 17 layers. The lowermost layer $\mathrm{C}$ has a thickness of 1 unit and a moderate stiffness (Young's modulus E of $10 \mathrm{GPa}$ ). Layers A are 0.2 units thick $(\mathrm{E}=100$ 
$\mathrm{GPa})$, layers $\mathrm{B} 0.05(\mathrm{E}=1 \mathrm{GPa})$. The layer contacts are as welded together. The hydrofracture is confined to the lowermost layer $\mathrm{C}$ and subject to a constant overpressure of $10 \mathrm{MPa}$.
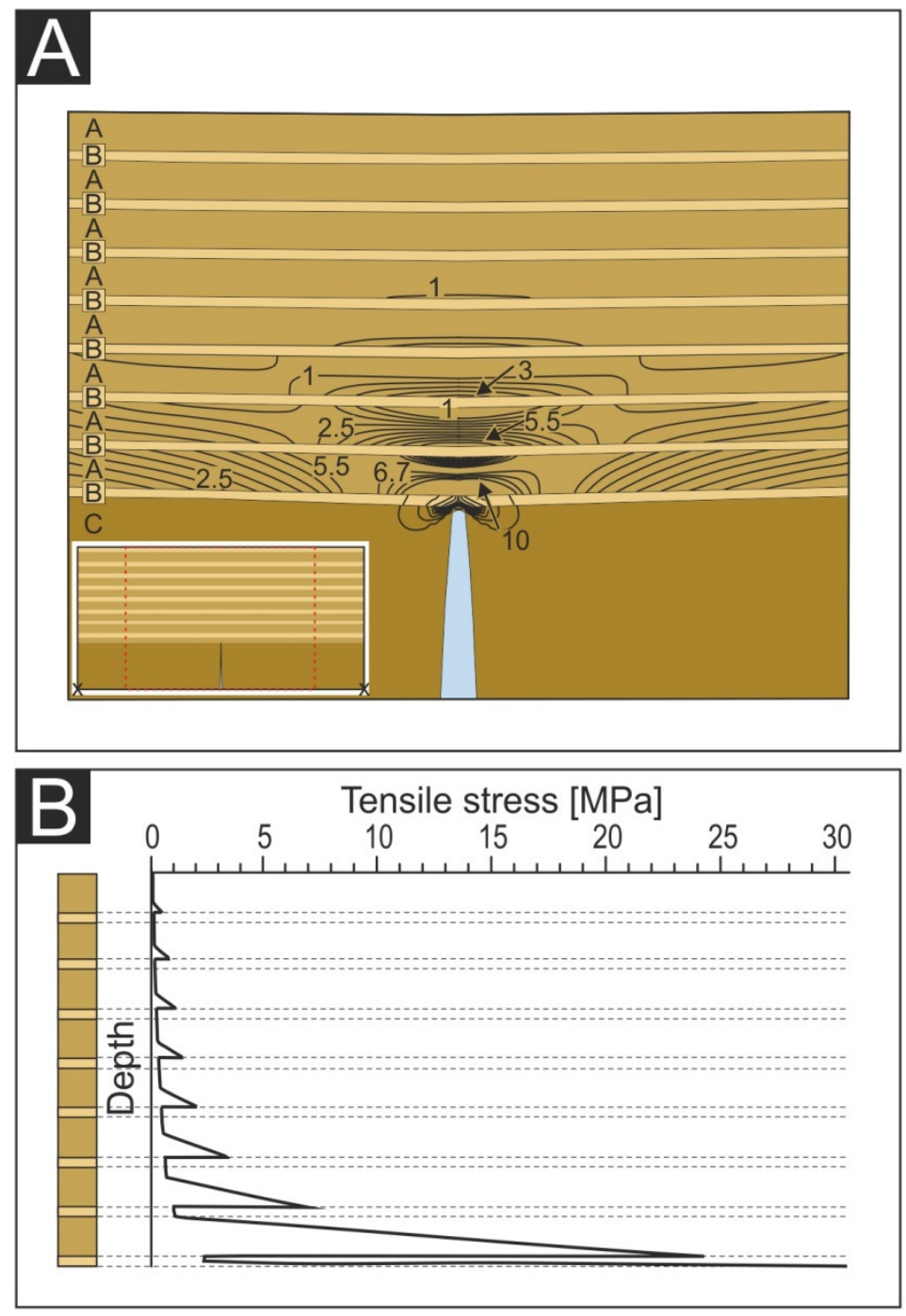

Figure 9.14: Boundary-element model of the tensile stress around a hydrofracture in a mechanically layered crust. The inset in A) shows the set-up of the model (cf. Fig. 9.12): the hydrofracture tip is at 2 units below the surface. In this model, the crossed layers A (thickness 0.2 units) are stiff, Young's modulus E $100 \mathrm{GPa}$, the dotted layers B (thickness 0.05 units) are very soft, $\mathrm{E}=1 \mathrm{GPa}$; in layer $\mathrm{C}$ Young's modulus is $40 \mathrm{GPa}$. Poisson's ratio is 0.25 in all the layers. A) Concentration of the maximum principal tensile stress $\sigma 3$, in megapascals (truncated at $1 \mathrm{MPa}$ and $10 \mathrm{MPa}$ ). The aperture of the hydrofracture is shown 150 times exaggerated and is largest in the soft layers. As the hydrofracture tip meets with the bottom of a soft layer, it becomes wide and blunt. There is high tensile stress concentration in the stiff layer above that could induce new fractures. However, only in a small area in the soft layer next to the hydrofracture, the tensile stress exceeds $10 \mathrm{MPa}$; B) Tensile stress distribution from the surface to the hydrofracture tip. Apart from the general increase of the tensile stress from zero at the surface to the tip, the tensile stress increases in the lower parts of all the stiff layers and is relatively lowest in all the soft layers with abrupt changes at the contacts between stiff and soft layers. The highest tensile stress, $30 \mathrm{MPa}$ occurs at the fracture tip, but this value is much lower than the tip stress for the homogeneous model (Fig. 9.12B). 
The hydrofracture tip at the contact with the lowermost soft layer B becomes rounded and relatively blunt (Fig. 9.14A). The stiff layers A take up much tensile stresses, particularly in their lower parts, so that new fractures could be induced in those parts. The soft layers B, however, suppress tensile stresses. The theoretical calculated tensile stress at the fracture tip in the soft layer is $30 \mathrm{MPa}$ (Fig. 9.14B), much lower than the tip stress of $149 \mathrm{MPa}$ for the homogeneous model above (Fig. 9.11B). In the soft layer next to the hydrofracture tip, tensile stresses exceed common in-situ tensile strengths of rocks (0.5-6 MPa; Haimson and Rummel, 1982; Schultz, 1995) only in a very small area. It is unlikely that the hydrofracture propagates through the soft layer unless the layer contains a suitable nearby subvertical discontinuity.

\subsection{Discussion}

In the numerical model above the contacts between layers of contrasting mechanical properties are as welded or bonded together (Fig. 9.14). Fracture propagation in bounded, layered materials, where the layers have different mechanical properties, has received much attention in the engineering literature (Daneshy, 1978; He and Hutchinson, 1989; Hutchinson and Suo, 1992; Valko and Economides, 1995). In the geological literature there has been considerable discussion of arrest by ductile or semi-ductile layers within stiff layers, but the effects of differences in stiffnesses (Young's moduli) between bounded stiff layers have received comparatively little attention (Bonafede and Rivalta, 1999a; b; Zhang et al., 2007). For the models (Figs. 9.11\& 9.14), constant fluid overpressure is applied to the hydrofracture along its entire length. However, in nature the tip of a hydrofracture commonly propagates ahead of its fluid front (Valko and Economides, 1995; Economides and Nolte, 2000). This is demonstrated by hydraulic fracture experiments and models which indicate that the fluid front normally lags behind the hydrofracture tip (Warpinski, 1985; Advani et al., 1997; Yew, 1997; Garagash and Detournay, 2000). We have run other numerical models where the part of the hydrofracture close to its tip is without any loading, whereas the hydrofracture was allowed to open along an internal spring of low stiffness (e.g. Brenner and Gudmundsson, 2002; 2004a; b; Gudmundsson et al., 2002). Such a loading represents zero overpressure, that is, a situation where the fluid pressure in the hydrofracture is in lithostatic equilibrium with the surrounding rocks.

A constant fluid overpressure, as applied in the numerical models here (Figs. $9.11 \& 9.14$ ) implies that, since the stress normal to the fracture normally increases downwards (as the lithostatic pressure does), the total fluid pressure must increase in the same way. Exceptions 
could occur in a strongly layered crust where the local stresses normal to the fracture would not increase gradually with depth (cf. Haimson and Rummel, 1982). In nature the fluid overpressure would normally increase upwards for fluids with a density $\rho_{f}$ less than the rock density $\rho_{r}$, such as water, due to the buoyancy effect (Eq. 4), but decrease upwards for fluids with a high density $\rho_{f}$, such as some mafic magmas. Consequently, in our numerical models we explore the average effect when $\rho_{f}=\rho_{r}$. Models of hydrofracture propagation with linearly varying overpressure distributions give similar solutions and essentially lead to the same conclusions (Gudmundsson and Brenner, 2001; Brenner and Gudmundsson, 2002; Gudmundsson et al., 2002).

Analytical models (Isida, 1955) and numerical models of hydrofractures in homogeneous, isotropic rocks (Fig. 9.11) show that the tensile stress concentration at the surface, or an interface, induced by a propagating fracture has two peaks (Pollard and Segall, 1987). Where the stress peaks are the most likely locations for induced offset fractures at weak interfaces. In the models, the location of the peak is given as a factor of the horizontal distance in comparison to the distance to the hydrofracture tip below the surface ('surface distance'). For the homogenous, isotropic model (Fig. 9.11C), the peak stress is $4 \mathrm{MPa}$ and occurs at a surface distance of 1.6. At a weak contact, such peak stresses, in the order of common in-situ tensile strengths, could be high enough to induce offset fractures. Mechanical layering, particularly horizontal discontinuities, may transfer the stress peaks at the surface, so that straightforward inversion of surface geodetic data may lead to unreliable inferred depths of hydrofracture tips (cf. Gudmundsson, 2006).

For fluid overpressure as the only loading, the soft layer would normally act as a stress barrier and thus favor hydrofracture arrest (Fig. 9.14, Brenner and Gudmundsson, 2002; 2004a; b; Larsen and Gudmundsson, 2010). In a reservoir subject to remote compression or tension, however, the results may be very different. When a layered reservoir is subject to horizontal tension, the tensile stresses that concentrate in the stiff layers are expected to be even higher, whereas soft layers still tend to be stress barriers (Gudmundsson and Brenner, 2001). When such a reservoir is subject to horizontal compression, however, the stiff layers are likely to take up most of the compressive stress and act as barriers to vertical hydrofracture propagation (Gudmundsson and Brenner, 2001). Thus, stiff layers are stress barriers in remote compression, whereas soft layers are stress barriers in remote tension or when fluid overpressure is the only loading. Extension of a sedimentary basin leads to relative tension, that is, reduction in compression. The relative tensile stresses concentrate in the stiff layers but not in the soft layers which, thereby, may have higher compressive stresses than the stiff 
layers and thus form stress barriers. This effect is well known in the petroleum industry (Economides and Nolte, 2000)

Because of possible flow channeling along the widest parts of a fracture (Wang, 1991; Tsang and Neretnieks, 1998), aperture variation is important for the permeability in fluid reservoirs. When fluid overpressure of the hydrofracture is the only loading, or the reservoir is subject to remote compression, the aperture of a vertical hydrofracture is greatest in the soft layers and least in the stiff layers (Brenner and Gudmundsson, 2002; Larsen and Gudmundsson, 2010; Gudmundsson et al., 2012). However, field observations in layered rocks indicate that in soft layers many hydrofractures are shear fractures. This has been observed, for example, for layered carbonate rocks in England (Fig. 9.15; Brenner and Gudmundsson, 2004a; b). There, calcite veins and joints mostly follow inclined shear fractures in the soft shale layers between limestone layers, where they are extension fractures. This indicates that, during hydrofracture formation, the shale had no tensile strength and failed in shear rather than in extension. Because inclined fractures are no longer perpendicular to the minimum principal compressive stress, $\sigma_{3}$, but normal to a higher stress $\sigma_{n}$, they normally are thinner than similar-sized extension fractures.

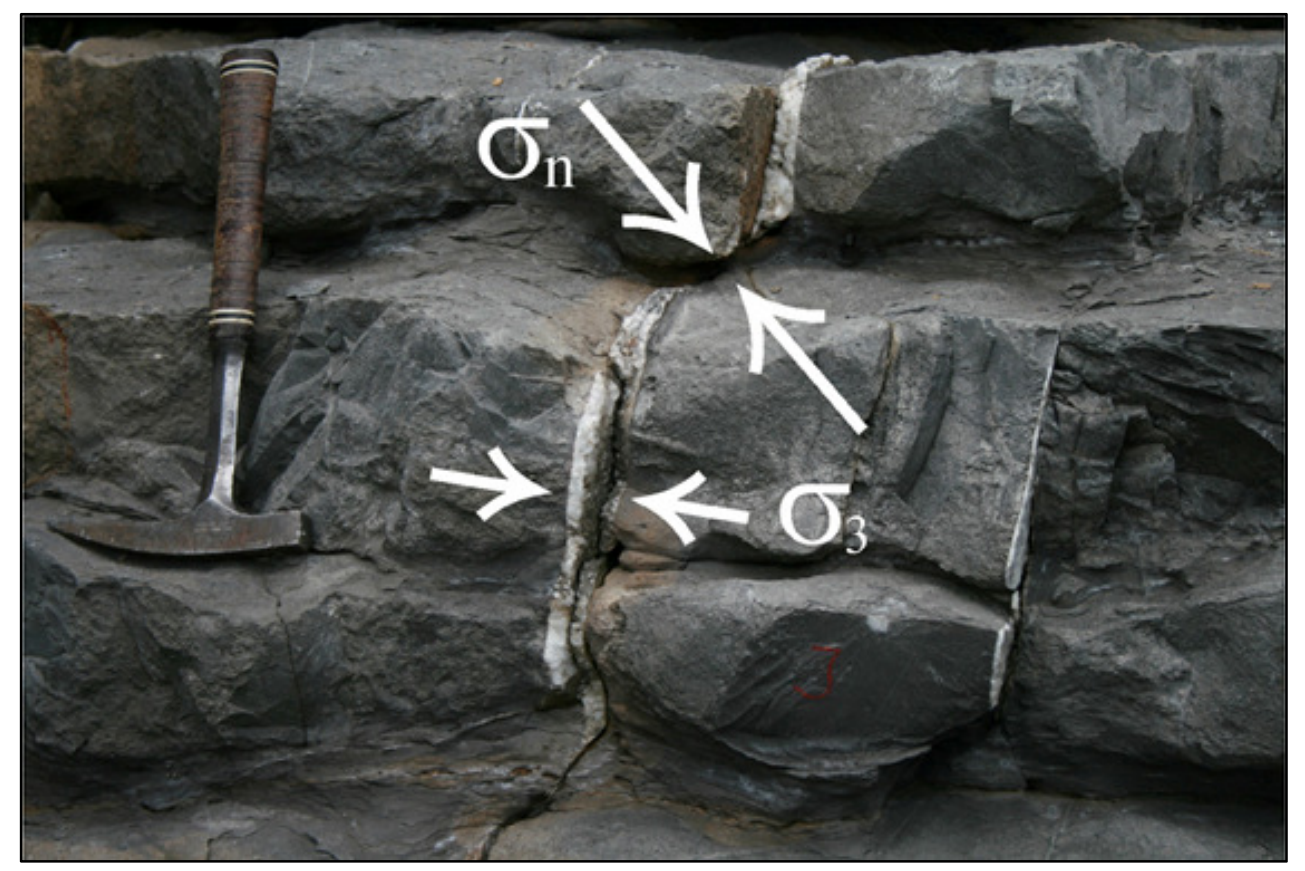

Figure 9.15: Aperture variation of a calcite vein at Kilve, Somerset Coast. In the grey limestone layer, the vein is a vertical extension fracture, with the minimum principal compressive stress $\sigma_{3}$ as its normal stress (as is indicated by arrows). In the marl layer, however, the vein is an inclined shear fracture, subject to a higher normal stress $\sigma_{n}$ and therefore thinner than the vertical part. View north; the hammer provides a scale (cf. Brenner and Gudmundsson, 2004a). 
The cubic law for fluid transport in rock fractures may not apply to fractures with rough walls, or where the aperture varies much along the fracture path. For elastic host rocks the aperture normally depends on the fluid pressure in the fracture, the state of stress in the rock, and the mechanical properties of the host rocks. For fractures with varying aperture, fluid flow may be channeled along their widest parts or greatest openings (Wang, 1991; Tsang and Neretnieks, 1998; Gudmundsson, 2011a). However, for such realistic fracture geometries, the Navier-Stokes equations have not yet been solved (cf. Zimmerman and Yeo, 2000).

Our field observations (Fig. 9.12) and numerical model (Fig. 9.14) indicate that, although shallow fractures may be more likely to be stratabound than fractures at deeper crustal levels (Odling et al., 1999; Gillespie et al., 2001), hydrofractures can become arrested at any crustal depth if there is a strong contrast in the mechanical properties of adjacent rock layers. This conclusion is supported by the observation that hydraulic fractures in petroleum engineering are commonly arrested at depths of several kilometers (Valko and Economides, 1995; Yew, 1997; Economides and Nolte, 2000). Very many fractures, such as joints and veins, tend to be restricted to single layers, particularly if the contacts between the layers are discontinuities or sites of abrupt changes in mechanical properties. Fracture restriction is also reflected in the commonly observed inverse correlation between joint frequency and layer thickness (Ladeira and Price, 1981; Nelson, 1985; Price and Cosgrove, 1990; Narr and Suppe, 1991; Wu and Pollard, 1995; Ji et al., 1998).

In a layered crust, individual layers with different mechanical properties become differently stressed as a result of remote tension or compression, fluid excess pressure in a reservoir, or the fracture-tip stresses of propagating hydrofractures (Amadei and Stephansson, 1997; Zang and Stephansson, 2010). For example, Haimson and Rummel (1982) measured large variations in the horizontal stresses in lava flows, and in petroleum reservoirs varying horizontal stresses are common (Engelder, 1993; Aguilera, 1995; Economides and Nolte, 2000). These heterogeneous local stress fields associated with mechanically layered rocks control hydrofracture propagation, or arrest, respectively. Through the injection of hydrofractures, as well as through faulting, however, the stress field may be gradually homogenised so that the probability of hydrofracture arrest decreases (Gudmundsson and Brenner, 2001). Also, host-rock alteration and diagenetic reactions such as mineral transitions, precipitation (cementation) and pressure solution and mechanical compaction may increase the stiffness of primarily soft layers, or soften primarily stiff layers, so that the stiffnesses of adjacent rock layers may gradually become more and more similar. Contacts may become sealed by similar processes so that the reservoir gradually becomes more homogeneous. Then, a multilayer that 
originally had contrasting properties may eventually behave mechanically as a single layer at the scale of propagating hydrofractures. The reservoir may still consist of different rock layers that can be clearly distinguished, but if the mechanical properties converge, propagating hydrofractures will no longer 'feel' these differences. It is only the mechanical layering that affects hydrofracture emplacement. It follows that the conditions for hydrofracture emplacement, and thus the permeability of a reservoir, may change significantly with time.

\section{Acknowledgments}

This work was funded by a PhD-Grant from Statoil through the University of Bergen, Norway, by the Dorothea-Erxleben Programme of the State of Lower Saxony, and the Deutsche Forschungsgemeinschaft.

\section{References}

Advani S.H., Lee T.S., Dean R.H., Pak C.K., Avasthi J.M. (1997) Consequences of fluid lag in threedimensional hydraulic fractures. International Journal for Numerical and Analytical Methods in Geomechanics, 21, 229-240.

Adler P.M., Thovert J.-F., Mourzenko V.V. (2012) Fractured Porous Media. Oxford University Press, Oxford.

Afrouz A.A. (1992) Practical Handbook of Rock Mass Classification Systems and Modes of Ground Failure. CRC Press, London.

Aguilera R. (1995) Naturally Fractured Reservoirs. PennWell Publishing Company, Tulsa, Oklahoma.

Aguilera R. (2000) Well test analysis of multi-layered naturally fractured reservoirs. Journal of Canadian Petroleum Technology, 39, 31-37.

Al-Busaidi A., Hazzard J.F., Young R.P. (2005) Distinct element modeling of hydraulically fractured Lac du Bonnet granite. Journal of Geophysical Research, 110, B06302, 1-14.

Amadei B., Stephansson O. (1997) Rock Stress and its Measurement. Chapman and Hall, London.

Atkins A.G., Mai Y.W. (1985) Elastic and Plastic Fracture. Horwood, Chichester, UK.

Aydin A. (2000) Fractures, faults, and hydrocarbon entrapment, migration and flow. Marine and Petroleum Geology, 17, 797-814.

Baer G. (1991) Mechanisms of dike propagation in layered rocks and in massive, porous sedimentary rocks. Journal of Geophysical Research, 96, 11911-11929.

Barton C.A., Zoback M.D., Moos D. (1995) Fluid flow along potentially active faults in crystalline rock. Geology, 23, 683-686.

Bear J. (1993) Modelling flow and contaminant transport in fractured rocks. In: Bear J., Tsang C.F., de Marsily G. (Eds.) Flow and Contaminant Transport in Fractured Rock. Academic Press, New York, pp. 1-37.

Becker A., Gross M.R. (1996) Mechanism for joint saturation in mechanically layered rocks: An example from southern Israel. Tectonophysics, 257, 223-237.

Bell F.G. (2000) Engineering Properties of Soils and Rocks. Fourth ed., Blackwell, Oxford.

Becerril L., Galindo I., Gudmundsson A., Morales J.M. (2013) Depth of origin of magma in eruptions. Scientific Reports, 3, 1-6.

Berkowitz B. (2002) Characterizing flow and transport in fractured geological media: A review. Advances in Water Resources, 25, 861-884.

Bonafede M., Danesi S. (1997) Near-field modifications of stress induced by dyke injection at shallow depth. Geophysical Journal International, 130, 435-448. 
Bonafede M., Rivalta E. (1999a) On tensile cracks close to and across the interface between two welded elastic half-spaces. Geophysical Journal International, 138, 410-434.

Bonafede M., Rivalta E. (1999b) The tensile dislocation problem in a layered elastic medium. Geophysical Journal International, 136, 341-356.

Bons P.D. (2001) The formation of large quartz veins by rapid ascent of fluids in mobile hydrofractures. Tectonophysics, 336, 1-17.

Bons P.D., Elburg M.A., Gomez-Rivas E. (2012) A review of the formation of tectonic veins and their microstructures. Journal of Structural Geology, 43, 33-62.

Bourbiaux B. (2010) Fractured reservoir simulation: a challenging and rewarding issue. Oil \& Gas Science and Technology-Rev. IFP., 65, 227-238.

Brebbia C.A., Dominguez J. (1992) Boundary Elements: an Introductory Course. Second ed., Computational Mechanics, Boston.

Brenner S.L. (2003) Field studies and models of hydrofractures in heterogeneous reservoirs. $\mathrm{PhD}$ thesis. University of Bergen, Bergen, Norway.

Brenner S.L., Gudmundsson A. (2002) Permeability development during hydrofracture propagation in layered reservoirs. Norges Geologiske Unders $\phi$ kelse Bulletin, 439, 71-77.

Brenner S.L., Gudmundsson A. (2004a) Permeability in layered reservoirs: field examples and models on the effects of hydrofracture propagation. In: Stephansson O., Hudson J.A., Jing L. (Eds.) Coupled Thermo-Hydro-Mechanical-Chemical Processes in Geo-Systems. Geo-Engineering Book Series, Elsevier, 2, pp. 643-648.

Brenner S.L., Gudmundsson A. (2004b) Arrest and aperture variation of hydrofractures in layered reservoirs. In: Cosgrove J.W., Engelder T. (Eds.) The Initiation, Propagation, and Arrest of Joints and Other Fractures. Geological Society of London, Special Publications, 231, pp. 117128.

Broberg K.B. (1999) Cracks and Fracture. Academic Press, London.

Brooks C.R., Choudhury A. (2002) Failure Analysis of Engineering Materials. McGraw-Hill, New York.

Bruhn R.L., Parry W.T., Yonkee W.A., Thompson T. (1994) Fracturing and hydrothermal alteration in normal fault zones. Pure and Applied Geophysics, 142, 609-644.

Caine J.S., Evans J.P., Forster C.B. (1996) Fault zone architecture and permeability structure. Geology, 24, 1025-1028.

Chapman R.E. (1981) Geology and Water: An Introduction to Fluid Mechanics for Geologists. Nijhoff, London.

Charlez P.A. (1997) Rock Mechanics, Volume 2: Petroleum Applications. Editions Technip, Paris.

Chester F.M., Logan J.M. (1986) Implications for mechanical properties of brittle faults from observations of the Punchbowl fault zone, California. Pure and Applied Geophysics, 124, 79106.

Chiaramonte L., Zoback M.D., Friedmann J., Stamp V. (2008) Seal integrity and feasibility of CO2 sequestration in the Teapot Dome EOR pilot: geomechanical site characterization. Environmental Geology, 54, 1667-1675.

Chilingar G.V., Serebryakov V.A., Robertson J.O. (2002) Origin and Prediction of Abnormal Formation Pressures. Elsevier, London.

Cobbing J., O'Dochartaigh B.E. (2007) Hydrofracturing water boreholes in hard rock aquifers in Scotland. Quarterly Journal of Engineering Geology and Hydrogeology, 40, 181-186.

Cook J., Gordon J.E. (1964) A mechanism for the control of crack growth in all-brittle systems. Proceedings of the Royal Society London A, 282, 508-520.

Cooke M.L., Underwood C.A. (2001) Fracture termination and step-over at bedding interfaces due to frictional slip and interface opening. Journal of Structural Geology, 23, 223-238.

Coward M.P., Daltaban T.S., Johnson H. (1998) Structural Geology in Reservoir Characterization. Geological Society of London, Special Publications, 127, pp. 1-272.

Dahlberg E.C. (1994) Applied Hydrodynamics in Petroleum Exploration. Springer, New York.

Dahm T. (2000) Numerical simulations of the propagation path and the arrest of fluid-filled fractures in the Earth. Geophysical Journal International, 141, 623-638. 
Dahm T., Hainzl S., Fischer T. (2010) Bidirectional and unidirectional fracture growth during hydrofracturing: Role of driving stress gradients. Journal of Geophysical Research, 115, B12322, 1-18.

Daneshy A.A. (1978) Hydraulic fracture propagation in layered formations. Society of Petroleum Engineers Journal, 18, 33-41.

Daniel I.M., Ishai O. (1994) Engineering Mechanics of Composite Materials. Oxford University Press, Oxford.

Davis P.M. (1983) Surface deformation associated with a dipping hydrofracture. Journal of Geophysical Research, 88, 5826-5834.

Davis G.H., Reynolds S.J. (1996) Structural Geology of Rocks and Regions. Wiley, New York.

Davison I. (1995) Fault slip evolution determined from crack-seal veins in pull-aparts and their implications for general slip models. Journal of Structural Geology, 17, 1025-1034.

de Marsily G. (1986) Quantitative Hydrogeology. Academic Press, New York.

Deming D. (2002) Introduction to Hydrogeology. McGraw-Hill, Boston.

Dietrich P., Helmig R., Sauter M., Hötzl H., Köngeter J., Teutsch G. (2005) Flow and Transport in Fractured Porous Media. Springer, Berlin.

Dresen G., Stephansson O., Zang A. (2006) Rock damage and fluid transport, part I. Pure and Applied Geophysics, 163, 1-278.

Economides M.J., Boney C. (2000) Reservoir stimulation in petroleum production. In: Economides M.J., Nolte K.G. (Eds.) Reservoir Stimulation. Wiley, New York, pp. 1-30.

Economides M.J., Nolte K.G. (2000) Reservoir Stimulation. Wiley, New York.

Engelder T. (1993) Stress Regimes in the Lithosphere. Princeton University Press, Princeton, USA.

Evans J.P., Forster C.B., Goddard J.V. (1997) Permeability of fault-related rocks, and implications for hydraulic structure of fault zones. Journal of Structural Geology, 19, 1393-1404.

Farmer I. (1983) Engineering Behaviour of Rocks. Chapman and Hall, London.

Faulkner D.R., Jackson C.A.L., Lunn R.J., Schlische R.W., Shipton Z.K., Wibberley C.A.J., Withjack M.O. (2010) A review of recent developments concerning the structure, mechanics and fluid flow properties of fault zones. Journal of Structural Geology, 32, 1557-1575.

Faybishenko B., Witherspoon P.A., Benson S.M. (2000) Dynamics of Fluids in Fractured Rocks. Wiley, New York.

Finkbeiner T., Barton C.A., Zoback M.D. (1997) Relationships among in-situ stress, fractures and faults, and fluid flow: Monterey formation, Santa Maria basin, California. American Association of Petroleum Geologists Bulletin, 81, 1975-1999.

Flekkoy E.G., Malthe-Sorenssen A., Jamtveit B. (2002) Modeling hydrofracture. Journal of Geophysical Research, 107, B8, 1-11.

Fyfe W.S., Price N.J., Thompson A.B. (1978) Fluids in the Earth's Crust. Elsevier, London.

Garagash D., Detournay E. (2000) The tip region of a fluid-driven fracture in an elastic medium. Journal of Applied Mechanics, 67, 183-192.

Geshi N., Kusumoto S., Gudmundsson A. (2010) The geometric difference between feeder and nonfeeder dikes. Geology, 38, 195-198.

Gillespie P.A., Walsh J.J., Watterson J., Bonson C.G., Manzocchi T. (2001) Scaling relationships of joint and vein arrays from The Burren, Co Clare, Ireland. Journal of Structural Geology, 23, 183-201.

Goodman R.E. (1989) Introduction to Rock Mechanics. Wiley, New York.

Grecksch G., Roth F., Kümpel H.J. (1999) Coseismic well-level changes due to the 1992 Roermond earthquake compared to static deformation of half-space solutions. Geophysical Journal International, 138, 470-478.

Gudmundsson A. (1999) Fluid overpressure and stress drop in fault zones. Geophysical Research Letters, 26, 115-118.

Gudmundsson A. (2000a) Active fault zones and groundwater flow. Geophysical Research Letters, 27, 2993-2996.

Gudmundsson A. (2000b) Fracture dimensions, displacements and fluid transport. Journal of Structural Geology, 22, 1221-1231.

Gudmundsson A. (2006) How local stresses control magma-chamber ruptures, dyke injections, and eruptions in composite volcanoes. Earth-Science Reviews, 79, 1-31. 
Gudmundsson A. (2011a) Rock Fractures in Geological Processes. Cambridge University Press, Cambridge, UK.

Gudmundsson A. (2011b) Deflection of dykes into sills at discontinuities and magma-chamber formation. Tectonophysics, 500, 50-64.

Gudmundsson A., Brenner S.L. (2001) How hydrofractures become arrested. Terra Nova, 13, 456462.

Gudmundsson A., Brenner S.L. (2005) On the conditions of sheet injections and eruptions in stratovolcanoes. Bulletin of Volcanology, 67, 768-782.

Gudmundsson A., Philipp S.L. (2006) How local stresses prevent volcanic eruptions. Journal of Volcanology and Geothermal Research, 158, 257-268.

Gudmundsson A., Fjeldskaar I., Brenner S.L. (2002) Propagation pathways and fluid transport of hydrofractures in jointed and layered rocks in geothermal fields. Journal of Volcanology and Geothermal Research, 116, 257-278.

Gudmundsson A., Simmenes T.H., Larsen B., Philipp S.L. (2010) Effects of internal structure and local stresses on fracture propagation, deflection, and arrest in fault zones. Journal of Structural Geology, 32, 1643-1655.

Gudmundsson A., Kusumoto S., Simmenes T.H., Philipp S.L., Larsen B., Lotveit I.F. (2012) Effects of overpressure variations on fracture apertures and fluid transport. Tectonophysics, 581, 220230.

Gulrajani S.N., Nolte K.G. (2000) Fracture evaluation using pressure diagnostics. In: Economides M.J., Nolte K.G. (Eds.) Reservoir Stimulation. Wiley, New York, pp. 1-9.

Gundersen E., Flekkoy E.G., Bjorlykke K., Feder J., Jamtveit B. (2011) Fracture spacing during hydro-fracturing of cap-rocks. Geofluids, 11, 280-293.

Haimson B.C., Rummel F. (1982) Hydrofracturing stress measurements in the Iceland research drilling project drill hole at Reydarfjordur, Iceland. Journal of Geophysical Research, 87, 6631-6649.

Haneberg W.C., Mozley P.S., Moore J.C., Goodwin L.B. (1999) Faults and Subsurface Fluid Flow in the Shallow Crust. American Geophysical Union, Washington DC.

Hardebeck J.L., Hauksson E. (1999) Role of fluids in faulting inferred from stress field signatures. Science, 285, 236-239.

Hatheway A.W., Kiersch G.A. (1982) Engineering properties of rocks. In: Carmichael R.S. (Eds.) Handbook of physical properties of rocks. CRC Press, Boca Raton, Fla., USA, pp. 289-331.

He M.Y., Hutchinson J.W. (1989) Crack deflection at an interface between dissimilar elastic materials. International Journal of Solids and Structures, 25, 1053-1067.

Heffer K.J., Fox R.J., McGill C.A., Koutsabeloulis N.C. (1997) Novel techniques show links between reservoir flow directionality, earth stress, fault structure and geomechanical changes in mature waterfloods. Society of Petroleum Engineers, 2, 91-98.

Heimpel M., Olson P. (1994) Buoyancy-driven fracture and magma transport through the lithosphere: models and experiments. In: Ryan M.P. (Eds.) Magmatic Systems. Academic Press, London, pp. 223-240.

Helgeson D.E., Aydin A. (1991) Characteristics of joint propagation across layer interfaces in sedimentary rocks. Journal of Structural Geology, 13, 897-911.

Heuze F.E. (1980) Scale effects in the determination of rock mass strength and deformability. Rock mechanics, 12, 167-192.

Hubbert, M.K., Rubey, W.W. (1959) Role of fluid pressure in mechanics of overthrust faulting Part I. Geological Society of America Bulletin, 70, 115-166.

Hubbert M.K., Willis D.G. (1957) Mechanics of hydraulic fracturing. Transactions of the American Institute of Mining and Metallurgical Engineers, 210, 153-168.

Hudson J.A., Harrison J.P. (1997) Engineering Rock Mechanics: an Introduction to the Principles. Pergamon, Oxford, UK.

Hutchinson J.W., Suo Z. (1992) Mixed-mode cracking in layered materials. Advances in applied mechanics, 29, 63-191.

Ingebritsen S.E., Sanford W.E. (1998) Groundwater in Geologic Processes. Cambridge University Press, Cambridge. 
Isida M. (1955) On the tension of a semi-infinite plate with an elliptic hole. Technical Report of the Faculty of Engineering, Tokushina University, 5, 75-95.

Jaeger J.C., Cook N.G.W. (1979) Fundamentals of Rock Mechanics. Chapman and Hall, London.

Ji S.C., Zhu Z.M., Wang Z.C. (1998) Relationship between joint spacing and bed thickness in sedimentary rocks: effects of interbed slip. Geological Magazine, 135, 637-655.

Jones G., Fisher Q.J., Knipe R.J. (2008) Faulting and Fault Sealing in Hydrocarbon Reservoirs. Geological Society, London, Special Publications, 147, 1-352.

Jumikis A.R. (1979) Rock Mechanics. Trans Tech Publications, Clausthal, Germany.

Kim J.W., Bhowmick S., Hermann I., Lawn B.R. (2006) Transverse fracture in brittle bilayers: relevance for failure of all-ceramic dental crowns. Journal of Biomedical Materials Research Part B: Applied Biomaterials, 79B, 58-65.

King C.Y., Azuma S., Igarashi G., Ohno M., Saito H., Wakita H. (1999) Earthquake-related waterlevel changes at 16 closely clustered wells in Tono, central Japan. Journal of Geophysical Research, 104, 13073-13082.

Kusumoto S., Geshi N., Gudmundsson A. (2013a) Aspect ratios and magma overpressures of nonfeeder dikes observed in the Miyake-jima volcano (Japan), and fracture toughness of its upper part. Geophysical Research Letters, 40, 1065-1068.

Kusumoto S., Gudmundsson A., Simmenes T.H., Geshi N., Philipp S.L. (2013b) Inverse modeling for estimating fluid-overpressure distributions and stress intensity factors from an arbitrary openfracture geometry. Journal of Structural Geology, 46, 92-98.

Kümpel H.J. (2003) Thermo-Hydro-Mechanical Coupling in Fractured Rock. Birkhäuser, Berlin.

Labaume P., Craw D., Lespinasse M., Muchez P. (2002) Tectonic processes and the flow of mineralising fluids. Tectonophysics, 348, 1-185.

Ladeira F.L., Price N.J. (1981) Relationship between fracture spacing and bed thickness. Journal of Structural Geology, 3, 179-183.

Larsen B., Grunnaleite I., Gudmundsson A. (2008) How fracture systems affect permeability development in shallow-water carbonate rocks: an example from the Gargano Peninsula, Italy. Journal of Structural Geology, 32, 1212-1230.

Larsen B., Gudmundsson A. (2010) Linking of fractures in layered rocks: Implications for permeability. Tectonophysics, 492, 108-120.

Lee C.H., Farmer I. (1993) Fluid Flow in Discontinuous Rocks. Chapman and Hall, London.

Lee J. J-W., Lloyd I.K., Chai H., Jung Y.-G., Lawn B.R. (2007) Arrest, deflection, penetration and reinitiation of cracks in brittle layers across adhesive interlayers. Acta Materialia, 55, 58595866.

Lister J.R., Kerr R.C. (1991) Fluid-mechanical models of crack propagation and their application to magma transport in dykes. Journal of Geophysical Research: Solid Earth, 96, 10049-10077.

Lonergan L., Jolly R.J.H., Rawnsley K., Sanderson D.J. (2007) Fractured Reservoirs. Geological Society of London, Special Publications, 270, pp. 1-296.

Mahrer K.D. (1999) A review and perspective on far-field hydraulic fracture geometry studies. Journal of Petroleum Science and Engineering, 24, 13-28.

Mandl G. (2005) Rock Joints: The Mechanical Genesis. Springer, Berlin.

Mandl G., Harkness R.M. (1987) Hydrocarbon migration by hydraulic fracturing. In: Jones M.E., Preston R.M.E. (Eds.) Deformation of Sediments and Sedimentary Rocks. Geological Society of London, Special Publication, 29, pp. 39-53.

Martí J., Geyer A. (2009) Central vs flank eruptions at Teide-Pico Viejo twin stratovolcanoes (Tenerife, Canary Islands). Journal of Volcanology and Geothermal Research, 181, 47-60.

Maugis D. (2000) Contact, Adhesion and Rupture of Elastic Solids. Springer, Berlin.

McCaffrey K.J.W., Lonergan, L., Wilkinson, J.J. (1999) Fractures, Fluid Flow and Mineralization. Geological Society of London, Special Publication, 155, pp. 1-338.

Muirwood R., King G.C.P. (1993) Hydrological signatures of earthquake strain. Journal of Geophysical Research, 98, 22035-22068.

Naceur K.B., Touboul E. (1990) Mechanisms controlling fracture-height growth in layered media. Society of Petroleum Engineers Production Engineering, 5, 142-150.

Narr W., Suppe J. (1991) Joint spacing in sedimentary rocks. Journal of Structural Geology, 13, 10371048 . 
Nasseri M.H.B., Mohanty B., Young R.P. (2006) Fracture toughness measurements and acoustic emission activity in brittle rocks. Pure and Applied Geophysics, 163, 917-945.

Nelson R.A. (1985) Geologic Analysis of Naturally Fractured Reservoirs. First ed., Gulf Publishing Company, Houston, Texas.

Nelson R.A. (2001) Geologic Analysis of Naturally Fractured Reservoirs. Second ed., ButterworthHeinemann, London.

Neuzil C.E. (2003) Hydromechanical coupling in geologic processes. Hydrogeology Journal, 11, 41 83.

Nunn J.A., Meulbroek P. (2002) Kilometer-scale upward migration of hydrocarbons in geopressured sediments by buoyancy-driven propagation of methane filled fractures. American Association of Petroleum Geologists Bulletin, 86, 907-918.

Odling N.E., Gillespie P., Bourgine B., Castaing C., Chilés J.-P., Christensen N.P., Fillion E., Genter A., Olsen C., Thrane L., Trice R., Aarseth E., Walsh J.J., Watterson J. (1999) Variations in fracture system geometry and their implications for fluid flow in fractured hydrocarbon reservoirs. Petroleum Geoscience, 5, 373-384.

Osborne M.J., Swarbrick R.E. (1997) Mechanisms for generating overpressure in sedimentary basins: A reevaluation. American Association of Petroleum Geologists Bulletin, 81, 1023-1041.

Paterson M.S. (1978) Experimental Rock Deformation: The Brittle Field. Springer, Berlin.

Peterson R.E. (1974) Stress Concentration Factors. Wiley, New York.

Philipp S.L. (2008) Geometry and formation of gypsum veins in mudstones at Watchet, Somerset, SW-England. Geological Magazine, 145, 831-844.

Philipp S.L. (2012) Fluid overpressure of mineral veins at Kilve, Somerset, SW England. Tectonophysics, 581, 35-47.

Pollard D.D., Segall P. (1987) Theoretical displacement and stresses near fractures in rocks: with application to faults, points, veins, dikes, and solution surfaces. In: Atkinson B. (Eds.) Fracture Mechanics of Rocks. Academic Press, London, pp. 277-349.

Price N.J., Cosgrove, J. (1990) Analysis of Geological Structures. Cambridge University Press, Cambridge, UK.

Priest S.D. (1992) Discontinuity Analysis for Rock Engineering. Chapman and Hall, London.

Ray R., Sheth H.C., Mallik J. (2007) Structure and emplacement of the Nandurbar-Dhule mafic dyke swarm, Deccan Traps, and the tectonomagmatic evolution of flood basalts. Bulletin of Volcanology, 69, 537-531.

Renshaw C.E., Pollard D.D. (1994) Numerical simulation of fracture set formation - A fracturemechanics model consistent with experimental observations. Journal of Geophysical Research, 99, 9359-9372.

Rijken P., Cooke M.L. (2001) Role of shale thickness on vertical connectivity of fractures: application of crack-bridging theory to the Austin Chalk, Texas. Tectonophysics, 337, 117-133.

Rijsdijk K.F., Owen G., Warren W.P., McCarroll D., van der Meer J.J.M. (1999) Clastic dykes in over-consolidated tills: evidence for subglacial hydrofracturing at Killiney Bay, eastern Ireland. Sedimentary Geology, 129, 111-126.

Roeloffs E.A. (1988) Hydrologic precursors to earthquakes - a review. Pure and Applied Geophysics, 126, 177-209.

Rojstaczer S., Wolf S., Michel R. (1995) Permeability enhancement in the shallow crust as a cause of earthquake-induced hydrological changes. Nature, 373, 237-239.

Rossmanith H.P. (Ed.) (1998) Mechanics of Jointed and Faulted Rock. Balkema, Rotterdam, The Netherlands.

Rubin A.M. (1995) Propagation of magma-filled cracks. Annual Review of Earth and Planetary Sciences, 23, 287-336.

Rummel F. (1987) Fracture mechanics approach to hydraulic fracturing stress measurements. In: Atkinson B. (Eds.) Fracture Mechanics of Rock. Academic Press, London, pp. 217-239.

Sahimi M. (2011) Flow and Transport in Porous Media and Fractured Rock: From Classical Methods to Modern Approaches. Wiley, New York.

Savin G.N. (1961) Stress Concentrations around Holes. Pergamon, London.

Schön J.H. (2004) Physical Properties of Rocks: Fundamentals and Principles of Petrophysics. Second ed., Elsevier, London. 
Schultz R.A. (1995) Limits on strength and deformation properties of jointed basaltic rock masses. Rock Mechanics and Rock Engineering, 28, 1-15.

Secor D.T. (1965) Role of fluid pressure in jointing. American Journal of Science, 263, 633-646.

Secor D.T., Pollard D.D. (1975) On the stability of open hydraulic fractures in the earth's crust. Geophysical Research Letters, 2, 510-513.

Selley R.C. (1998) Elements of Petroleum Geology. Academic Press, London.

Sibson R.H. (1996) Structural permeability of fluid-driven fault-fracture meshes. Journal of Structural Geology, 18, 1031-1042.

Simonson E.R., Abou-Sayed A.S., Clifton R.J. (1978) Containment of massive hydraulic fractures. Society of Petroleum Engineers, 18, 27-32.

Singhal B.B.S., Gupta R.P. (1999) Applied Hydrogeology of Fractured Rocks. Kluwer, London.

Sleep N.H., Fujita K. (1997) Principles of Geophysics. Blackwell, Oxford, UK.

Smart B.G.D., Somerville J.M., Edlman K., Jones C. (2001) Stress sensitivity of fractured reservoirs. Journal of Petroleum Science and Engineering, 29, 29-37.

Smith M.B., Shlyapobersky J.W. (2000) Basics of hydraulic fracturing. In: Economides M.J., Nolte K.G. (Eds.) Reservoir Stimulation. Wiley, New York, pp. 1-5.

Smits A.J. (2000) A Physical Introduction to Fluid Mechanics. Wiley, New York.

Sneddon I.N., Lowengrub M. (1969) Crack Problems in the Classical Theory of Elasticity. Wiley, New York.

Spence D.A., Turcotte D.L. (1985) Magma-driven propagation of cracks. Journal of Geophysical Research, 90, 575-580.

Spence D.A., Sharp P.W., Turcotte D.L. (1987) Buoyancy-Driven Crack-Propagation - a Mechanism for Magma Migration. Journal of Fluid Mechanics, 174, 135-153.

Spence G.H., Redfern J., Aguilera R., Bevan T.G., Cosgrove J.W., Couples G.D., Daniel J.-M. (2013) Advances in the Study of Fractured Reservoirs. Geological Society of London, Special Publications, 374, pp. 1- 425.

Stauffer D., Aharônî A. (1994) Introduction to percolation theory. Rev. second ed., Taylor \& Francis Ltd, London.

Stearns D.W., Friedman M. (1972) Reservoirs in fractured rocks. American Association of Petroleum Geologists Memoir, 16, 82-106.

Stewart M.A., Klein E.M., Karson J.A., Brophy J.G. (2003) Geochemical relationships between dikes and lavas at the Hess Deep Rift: Implications for magma eruptibility. Journal of Geophysical Research, 108, B4, 1-15.

Sun R.J. (1969) Theoretical size of hydraulically induced horizontal fractures and corresponding surface uplift in an idealized medium. Journal of Geophysical Research, 74, 5995-6011.

Taylor W.L., Pollard D.D., Aydin A. (1999) Fluid flow in discrete joint sets: Field observations and numerical simulations. Journal of Geophysical Research, 104, 28983-29006.

Teufel L.W., Clark J.A. (1984) Hydraulic fracture propagation in layered rock: Experimental studies of fracture containment. Society of Petroleum Engineers, 24, 19-32.

Tsang C.F., Neretnieks I. (1998) Flow channeling in heterogeneous fractured rocks. Reviews of Geophysics, 36, 275-298.

Tvergaard V., Hutchinson J.W. (2008) Mode III effects on interface delamination. Journal of the Mechanics and Physics of Solid, 65, 215-229.

Twiss R.J., Moores E.M. (2006) Structural Geology. Second ed., W.H. Freeman, New York.

Valko P., Economides M.J. (1995) Hydraulic Fracture Mechanics. Wiley, New York.

van der Pluijm B.A., Marshak S. (2003) Earth Structure. Second ed., McGraw Hill, New York.

van Eekelen H.E.M. (1982) Hydraulic fracture geometry: fracture containment in layered formations. Society of Petroleum Engineers, 22, 341-349.

van Golf-Racht T.D. (2009) Fundamentals of Fractured Reservoir Engineering. Elsevier, London.

Vermilye J.M., Scholz C.H. (1995) Relation between vein length and aperture. Journal of Structural Geology, 17, 423-434.

Vigneresse J.L. (2001) Fluids and fractures in the lithosphere. Tectonophysics, 336, 1-244.

Wang J.S.Y. (1991) Flow and transport in fractured rocks. Reviews of Geophysics, 29, 254-262.

Warpinski N.R. (1985) Measurement of width and pressure in a propagating hydraulic fracture. Society of Petroleum Engineers Journal, 25, 46-54. 
Warpinski N.R., Schmidt R.A., Northrop D.A. (1982) In-situ stress: The predominant influence on hydraulic fracture containment. Journal of Petroleum Technology, 34, 653-664.

Warpinski N.R., Teufel L.W. (1987) Influence of geologic discontinuities on hydraulic fracture propagation. Journal of Petroleum Technology, 39, 209-220.

Weertman J. (1971) Theory of water-filled crevasses in glaciers applied to vertical magma transport beneath oceanic ridges. Journal of Geophysical Research, 76, 1171-1183.

Weertman J. (1996) Dislocation Based Fracture Mechanics. World Scientific, London.

Wu H.Q., Pollard D.D. (1995) An experimental study of the relationship between joint spacing and layer thickness. Journal of Structural Geology, 17, 887-905.

Yew C.H. (1997) Mechanics of Hydraulic Fracturing. Gulf Publishing, Houston, USA.

Zang A., Stephansson O. (2010) Stress Field of the Earth's Crust. Springer, Berlin.

Zhang X., Jeffrey R.G., Thiercelin M. (2007) Deflection and propagation of fluid-driven fractures at frictional bedding interfaces: a numerical investigation. Journal of Structural Geology, 29, 396-410.

Zimmerman R.W., Yeo I.-W. (2000) Fluid Flow in Rock Fractures: From the Navier-Stokes Equations to the Cubic Law. In: Faybishenko B., Witherspoon P.A., Benson S.M. (Eds.) Dynamics of Fluids in Fractured Rock. Geophysical Monograph 122, American Geophysical Union, Washington, pp. 213-224. 


\title{
-Chapter 10-
}

\section{Fracture arrest at limestone-marl contacts depending on marl thickness, stiffness and contact properties-Insights from BEM modelling}

\author{
Filiz Afşar ${ }^{a}$ \\ ${ }^{a}$ University of Göttingen, Geoscience Centre (GZG), Structural Geology and Geodynamics, Goldschmidtstraße \\ 3, D-37077 Göttingen, Germany
}

Manuscript in preparation

\begin{abstract}
The change of mechanical properties between layers ('mechanical layering') and stress barriers such as lithological contacts, layer thicknesses and heterogeneities within layers influence fracture propagation in limestone-marl alternations. The nature of different lithological contacts are important since, at weak contacts, fractures tend to become arrested. However, welded contacts are strongly cohesive and fractures tend to propagate collinearly through these contacts. Numerical two-layered models using the boundary-element method (BEM) which allows investigating the stress losses between lithological contacts and model surfaces were used. Based on these models different stress barriers were evaluated in order to investigate the impact of different lithological contacts (welded or weak contact), layer thicknesses and contrast of Young's moduli ( $\mathrm{E}=40 \mathrm{GPa}$ for the lower and $\mathrm{E}$ from 2 to 30 $\mathrm{GPa}$ for the upper layer) on fracture propagation.

The results show that more tensile stress reaches the surface of the welded-contact model when the layer ahead of a hydrofracture is thin and stiff compared to thin and soft. The weakcontact models show that different Young's moduli in moderately thick upper layers do not affect the maximum tensile stress or the decrease of tensile stress between contacts and model surfaces. These models, however, show a changing effect of Young's moduli below the thickness threshold on the concentration of the maximum tensile stress between lithological contact and model surface. We determined a minimum critical thickness unit in which fewer fractures can propagate through this thickness threshold under different loading conditions (hydrofractures and tensile fractures). The quantification of critical marl thicknesses for the arrest of fractures makes predictions of fracture networks in layered rocks applicable for better fluid flow models.
\end{abstract}




\subsection{Introduction}

Layered reservoirs are characterised by the change of mechanical properties between layers ('mechanical layering'; cf. Aguilera, 2000; Philipp et al., 2013; see chapter 9 for details). Fractures in such reservoirs control the migration of fluids and depending on the fracture network the permeability of many reservoirs (Mandl and Harkness, 1987; Aydin, 2000; Nunn and Meulbroek, 2002; Philipp et al., 2013; see chapter 9 for details). However, as a result of mechanical layering, fractures tend to be more confined to individual layers than in massive rocks (Odling et al., 1999). Fracture arrest or propagation in such heterogeneous rocks is primarily controlled by local variations in the stress field, mainly due to discontinuities, such as lithological contacts, or the change of mechanical properties, in particular of Young's modulus (Gudmundsson \& Brenner, 2001). However, not all lithological contacts prevent fracture arrest, as this mainly depends on the cohesive bond of these contacts (cf. Price, 1966; cf. Hobbs, 1967). In the case of weak or open contacts, fractures become either arrested or offset (Philipp et al., 2013; see chapter 9 for details). In contrast, when the contact is strongly cohesive, fractures tend to propagate collinear through the contacts ('welded-layered model'; Hobbs, 1967).

In this study the boundary-element method (BEM) was used for numerical models, allowing accurate solutions of stresses at model surfaces. Two-layer models were generated to evaluate the impact of different lithological contacts (weak or welded contact) with increasing marl thicknesses and varying Young's moduli on fracture propagation by simulating the termination of hydro- and tensile fractures at these different contacts. Our goal was to quantify a minimum critical thickness unit in which fewer fractures can propagate through this thickness threshold (Philipp et al., 2013; see chapter 9 for details).

\subsection{Numerical model geometries}

The commercial software BEASY was used to create a two-dimensional numerical model, applying the boundary-element method (BEM). The simple two-layer model geometry comprises a lower layer A representing limestone with a constant thickness (100 units) for all model runs and an upper layer B representing marls with varying thicknesses $(1,2,5,10,20$, 30, 40, 50 units) for each model run (Fig. 10.1). The wedge-shaped fracture has a maximum width of 1 unit and a half-length of 95 units and is hosted in layer A with the centre at the middle of the lower model boundary (Fig. 10.1). At the fracture front, an internal spring with 
stiffness $0 \mathrm{MPa} / \mathrm{m}$ was defined, representing a fluid lag at the hydrofracture tip and an open vertical discontinuity at the tensile fracture tip (cf. Brenner, 2003; Fig.10.1). This internal spring allows the propagation ahead of the fluid and fracture front (cf. Brenner, 2003).

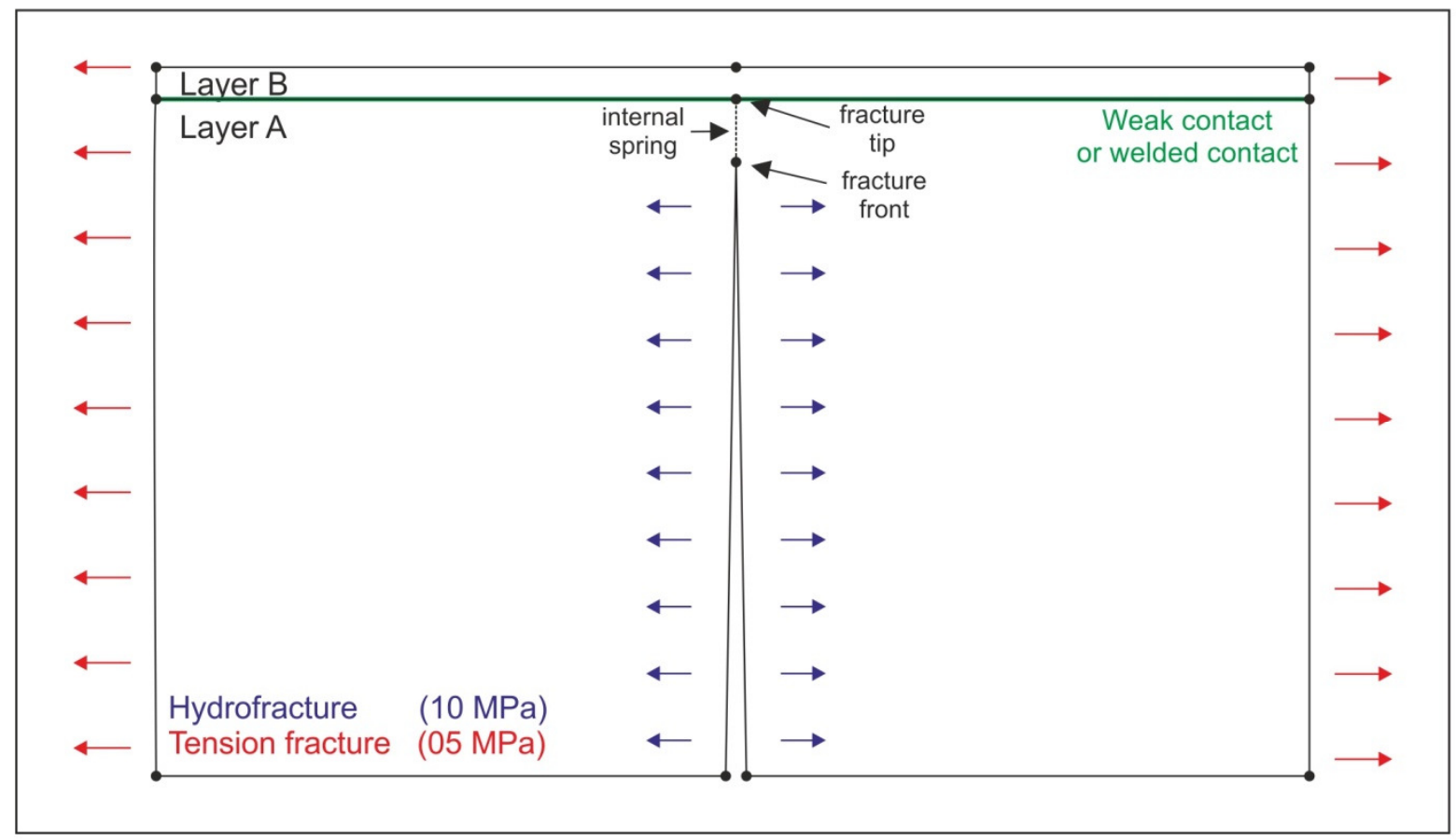

Figure 10.1: Geometry of the basic two-layer model. Four main model series with (1) weak or (2) welded contact, respectively, (in green) were run. For both model series loading conditions were defined for a (3) hydrofracture (in blue) and for a (4) tension fracture (in red).

Four model series were generated to distinguish variations in the stress field of a two-layered model with a weak or a welded limestone-marl contact, respectively. For each contact property model series of different loading conditions (hydrofracture and tensile fracture) were simulated (Fig. 10.1).

The mechanical properties such as the Young's modulus $(\mathrm{E}=40 \mathrm{GPa})$ and Poisson's ratio $(v=0.34)$ of layer A are uniform. Layer A represents a limestone bed in both model series. According to laboratory measurements, the average value of two representative limestone samples were taken for the Young's modulus of layer A (Afşar et al., 2014, see chapter 6 for details). The value of Poisson's ratio was chosen based on literature sources measured on fine-grained argillaceous limestones of the Blue Lias Formation at the Dorset coast (Hobbs et al., 2012). Here we have to consider that in situ static Young's moduli tend to be as much as 1.5 to 5 times lower than those measured in the laboratory of the same rock type (Heuze 1980; Philipp et al. 2013; see chapter 9 for details). Layer B represents the marl layer with changing thicknesses and Young's moduli for each model run. The Young's modulus presents values of 2, 5, 10, 20, and $30 \mathrm{GPa}$. Hence, these Young's moduli values were chosen based on 
measured values in marls (10 to $35 \mathrm{GPa}$ ) from the Lias mudstone (Reeves et al., 2006). Since the Poisson's ratio of different marls varies only within a small range between 0.3 and 0.33 (Dvorkin, 2001), the same Poisson's ratio $(v=0.34)$ was chosen for both layers A and B.

The weak contacts were modelled as internal springs of $6 \mathrm{MPa} / \mathrm{m}$ stiffness, whereas in the case of welded contacts the properties were not defined. Perpendicular to the fracture, a constant traction of $10 \mathrm{MPa}$ was applied to simulate fluid overpressure for hydrofractures and $5 \mathrm{MPa}$ external tension was applied to simulate tensile fractures (Fig. 10.1). A total of 160 model runs were generated.

\subsection{Results and interpretation}

\subsubsection{Maximum principle tensile stress at boundaries (lithological contact and model surfaces)}

The maximum tensile stress at both boundaries (contact and model surface) decreases with increasing thickness on all four model series (Figs. $10.2 \&$ 10.3). The maximum tensile stress

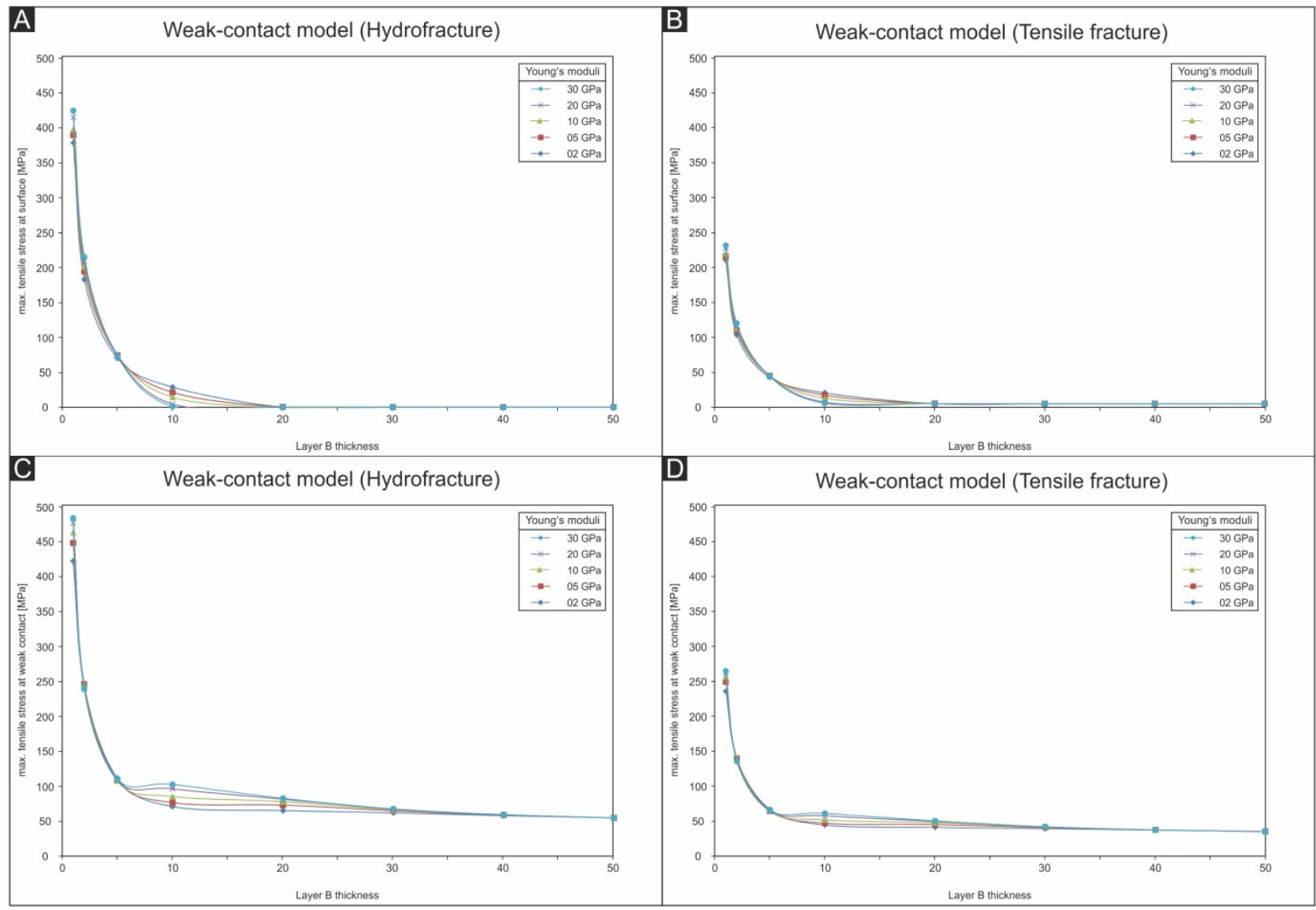

Figure 10.3: Weak-contact models show that with decreasing layer B thickness the maximum principle tensile stress with given Young's moduli increase. Graphs show the concentration of tensile stress at the model surface of a generated hydrofracture (A) and tensile fracture (B) and at the weak contact of a generated hydrofracture (C) and tensile fracture (D). 
for hydrofractures is generally higher than for the tensile fracture in welded- and weak-contact models (Figs. 10.2 \& 10.3).
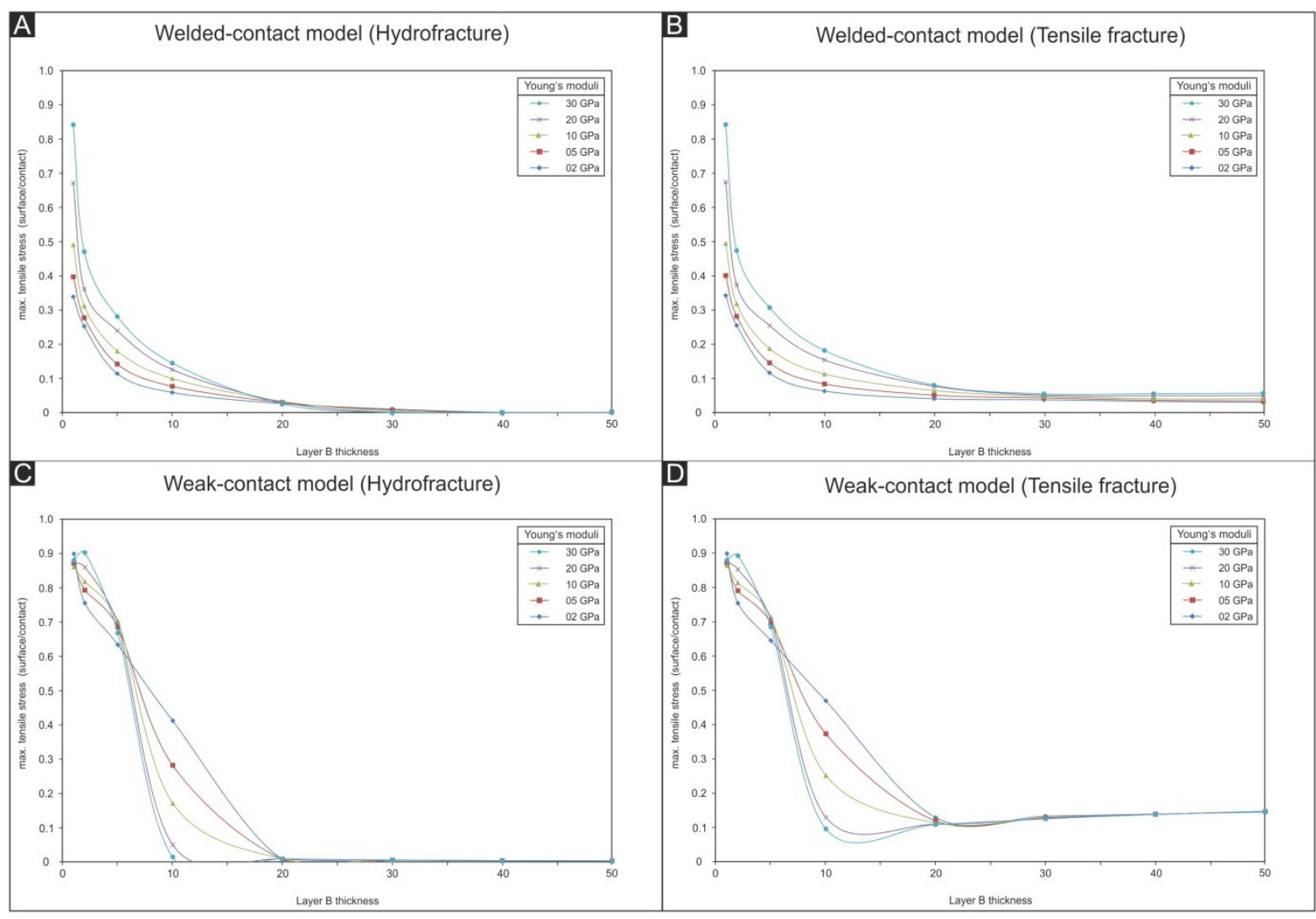

Figure 10.4: Ratio of maximum tensile stress between model surface and lithological contact with given layer B thicknesses for welded-contact models with hydrofractures (A) and tensile fractures (B) and weak-contact models with hydrofractures (C) and tensile fractures (D).

The results show that the maximum tensile stress at welded contacts with changing Young's modulus decrease more gradually with increasing thickness (Figs. 10.2C,D), compared with the model with weak contacts in which the effects of different Young's moduli in some layer B thickness units (e.g. 2,5,30,40,50) are less profound (Fig. 10.3C,D). In contrast, at the surfaces of both welded- and weak-contact model the effects of different Young's moduli on the maximum tensile stress changes depending on different thickness units (Figs. 10.2A,B \& 10.3A,B). Additionally, for the weak-contact models the concentration of maximum tensile stress at the surface shows an inversion at thickness units 2 and 10 (Fig. 10.3A,B). For instance, the contrast of Young's moduli between layer A $(E=40 \mathrm{GPa})$ and $\mathrm{B}(\mathrm{E}=2 \mathrm{GPa})$ is high, the maximum tensile stress is low for a thin B layer (thickness unit 2), but high for moderately thick B layer (thickness unit 10) at the same contrast of Young's moduli (Fig. 10.3A,B). This inversion effect controlled by the layer B thickness cannot be observed within the welded-contact model (Fig. 10.2A,B). 
The results show that the decrease of tensile stress between lithological contacts and the model surfaces in welded-contact models with hydrofractures and tensile fractures is more gradual than in the weak-contact models (Fig. 10.4). For hydrofracture propagation more tensile stress reaches the surface of the welded-contact model when layer B is thin $(<10$ thickness units) and stiff (e.g. $\mathrm{E}=30 \mathrm{GPa})$ compared with thin and soft (e.g. $\mathrm{E}=2 \mathrm{GPa})$ (Fig. 10.4A). Additionally, this model shows that different Young's moduli effects on the maximum tensile stress or the decrease of tensile stress between contacts and model surfaces vanish for very moderately thick B layers (>20 thickness units) (Fig. 10.4A). Consequently, the thickness unit of 20 is the minimum critical thickness unit for which less fractures can propagate through this thickness threshold (Fig. 10.4A). In the welded-contact-tension fracture models, however, the equivalent thickness threshold lies at 30 thickness units (Fig. 10.4B). Both thickness thresholds are comparable with weak-contact models (Fig. 10.4C,D). Additionally, the weak-contact models show the inversion effect of Young's moduli on the concentration of the maximum tensile stress between lithological contact and model surface below the discussed thickness thresholds (Fig. 10.4C,D).
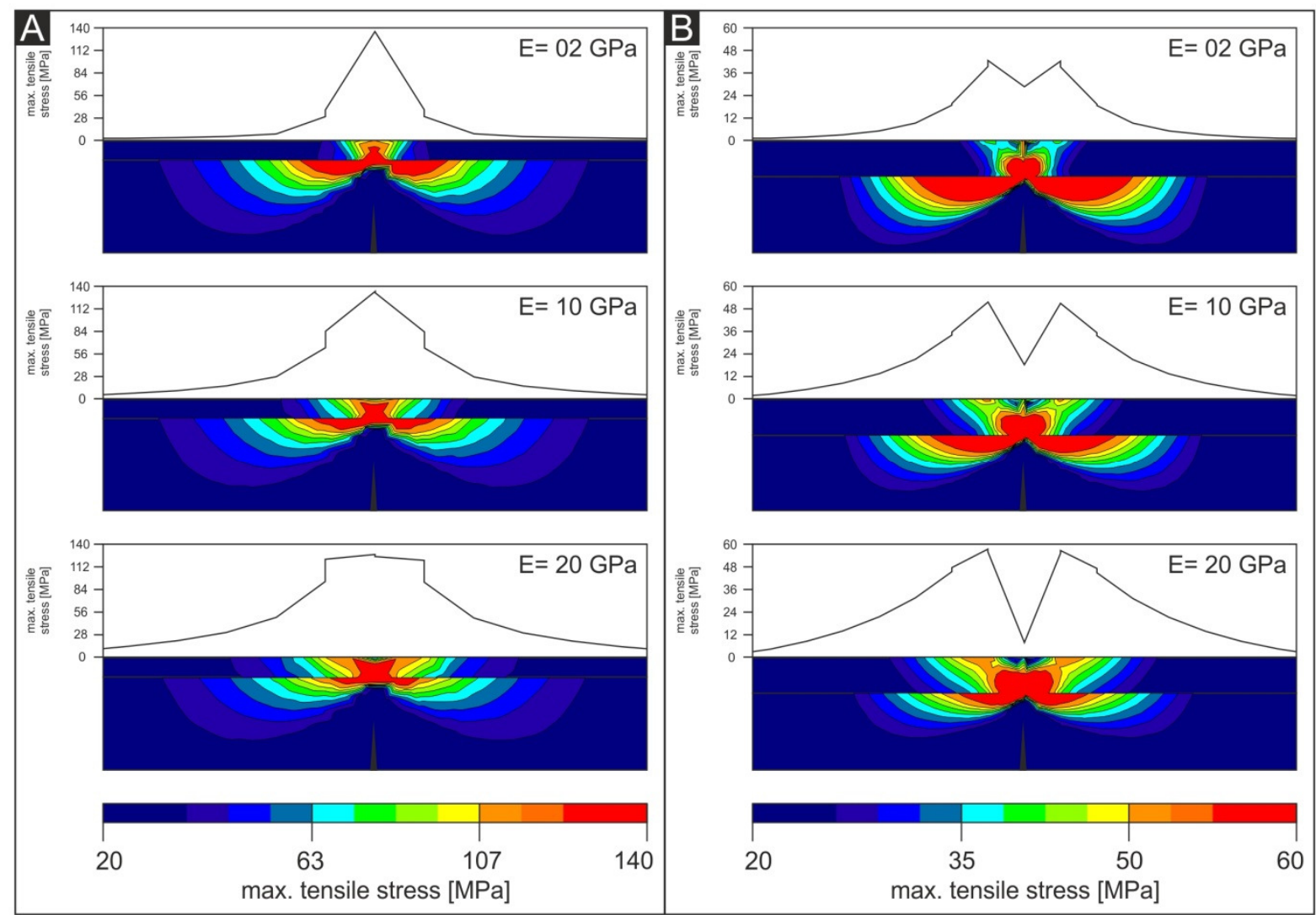

Figure 10.5: Selected welded-contact models show the resulting maximum principle tensile stress at the model surface plotted as graph and the distribution of tensile stress around a hydrofracture in layer $\mathrm{A}(\mathrm{E}=40 \mathrm{GPa})$ and layer $\mathrm{B}(\mathrm{E}=02,10,20 \mathrm{GPa})$ plotted as contour diagrams in thickness unit 2 (A) and thickness unit $5(\mathrm{~B})$. 


\subsubsection{Distribution of tensile stress in layer $A$ and $B$}

The distribution of maximum principle tensile stress in layer A and B is shown as diagrams in figures 10.A-10.D (see appendix). The welded-contact models show for hydrofractures and tensile fractures in layer B similar distribution of tensile stress with some wider spread with increasing Young's moduli (Figs. 10.A \& 10.B; see appendix).

Model runs with low thickness (thickness unit 2, Fig. 10.6A) show that the maximum tensile stress at the surface forms one peak, whereas the maximum tensile stress at the surface in model runs with higher thickness (thickness unit 5, Fig 10.6B) forms two peaks. In case of one peak, the fracture is able to propagate through the contact, whereas in cases of two peaks the fracture becomes rather offset along these welded contacts (Figs. $10.5 \& 10.6$ ). Note that the single peak can only be resolved to a spatial resolution of 5 units; higher resolution model runs may resolve variations of maximum tensile stress within these peaks. Nonetheless,
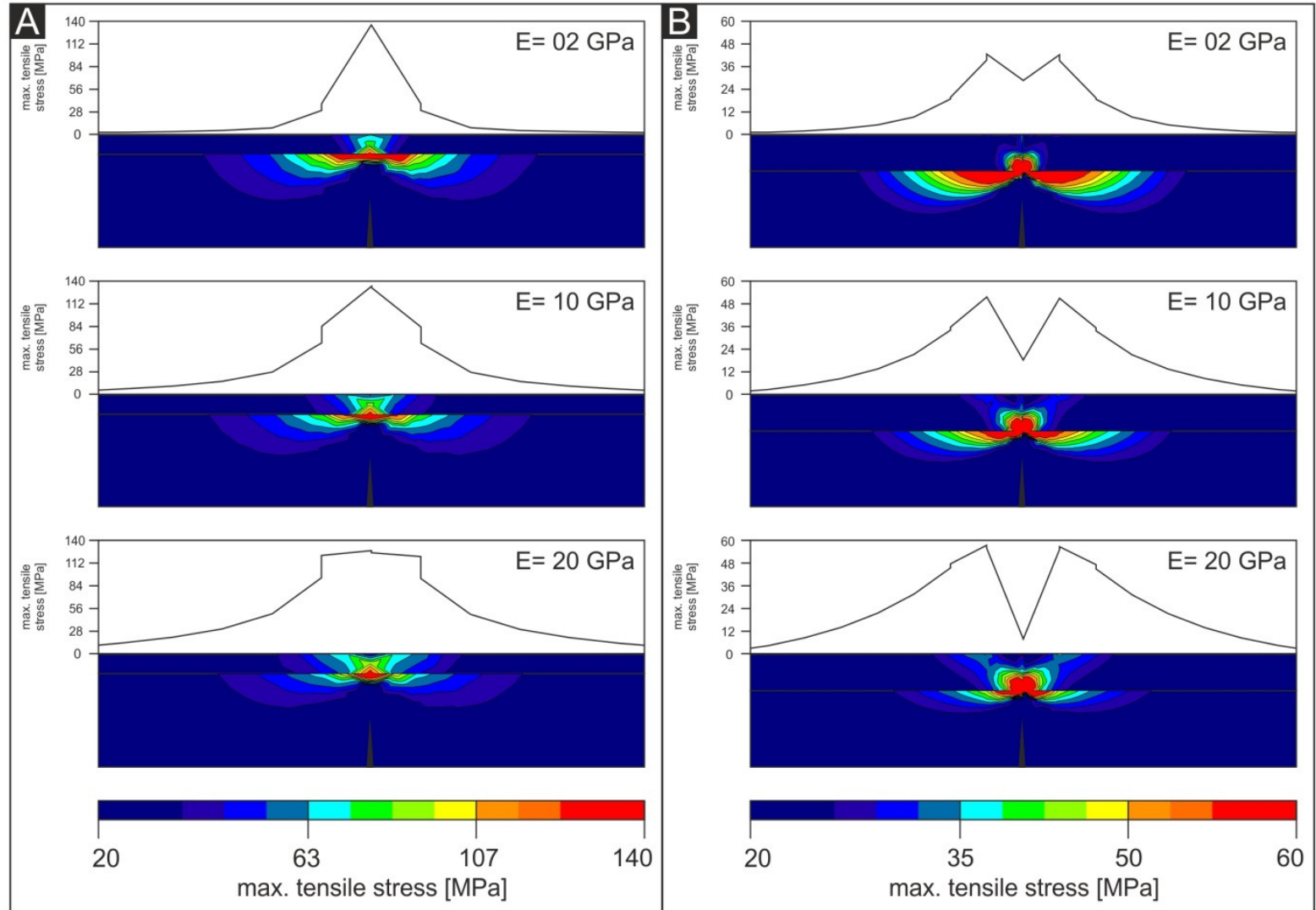

Figure 10.6: Selected welded-contact models show the resulting maximum principle tensile stress at the model surface plotted as graph and the distribution of tensile stress around a tensile fracture in layer $\mathrm{A}(\mathrm{E}=40 \mathrm{GPa})$ and layer $\mathrm{B}(\mathrm{E}=02,10,20 \mathrm{GPa})$ plotted as contour diagrams in thickness unit 2 (A) and thickness unit 5 (B). 

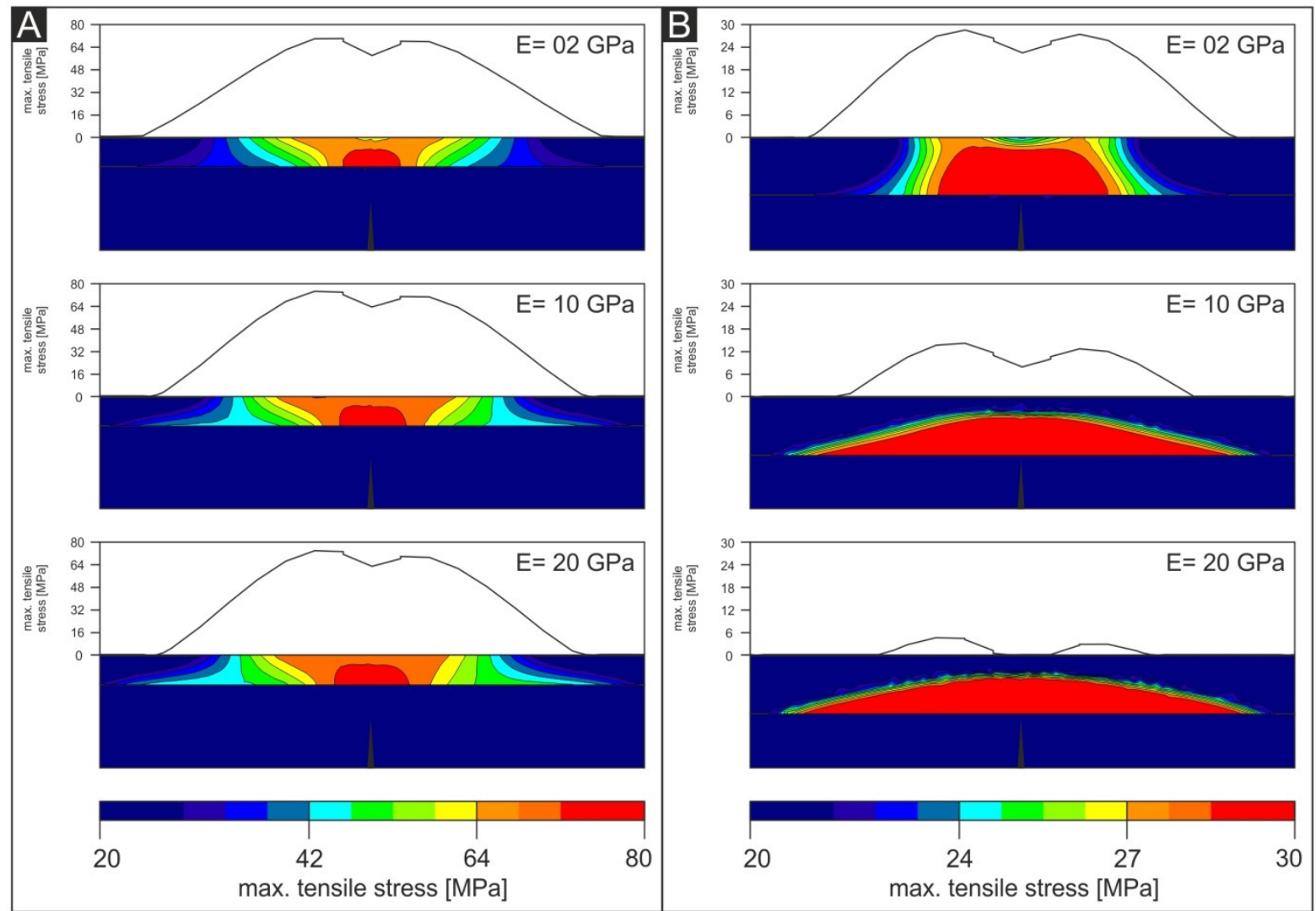

Figure 10.7: Selected weak-contact models show the resulting maximum principle tensile stress at the model surface plotted as graph and the distribution of tensile stress around a hydrofracture in layer $\mathrm{A}(\mathrm{E}=40 \mathrm{GPa})$ and layer $\mathrm{B}(\mathrm{E}=2,10,20 \mathrm{GPa})$ plotted as contour diagrams in thickness unit $5(\mathrm{~A})$ and thickness unit $10(\mathrm{~B})$.

the concentration of maximum tensile stress in a narrow part of the layer surface promotes fracture propagation. In contrast, models with weak contacts show two peaks at the model surface in all thickness units (Figs. $10.7 \& 10.8$ ). 


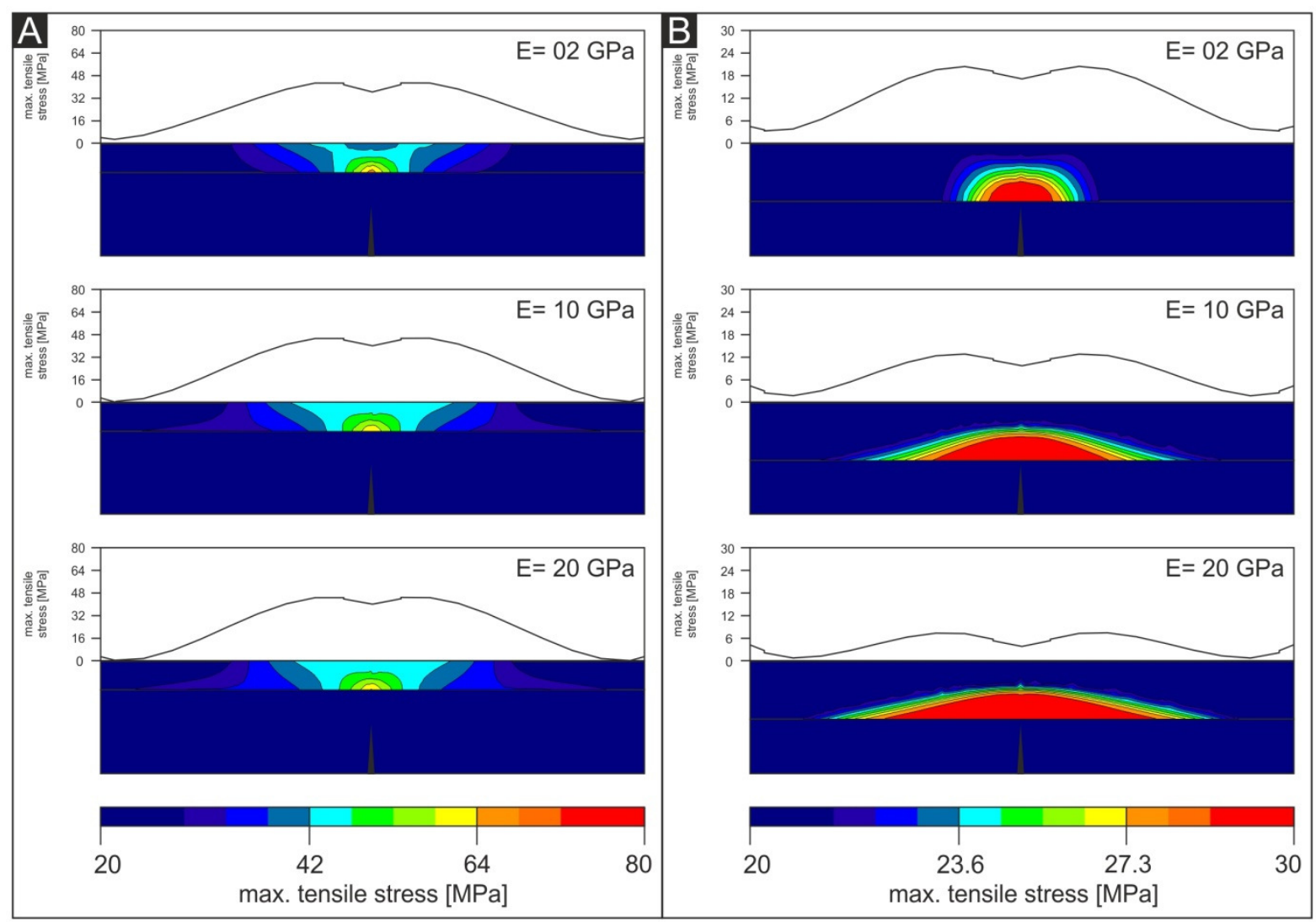

Figure 10.8: Selected weak-contact models show the resulting maximum principle tensile stress at the model surface plotted as graph and the distribution of tensile stress around a tensile fracture in layer $\mathrm{A}(\mathrm{E}=40 \mathrm{GPa})$ and layer $\mathrm{B}(\mathrm{E}=02,10,20 \mathrm{GPa})$ plotted as contour diagrams in thickness unit 5 (A) and thickness unit 10 (B).

\subsection{Conclusions}

The aim of this study was to evaluate the impact of terminating hydro- and tensile fractures at different lithological contacts (welded or weak contact) under changing layer thicknesses and Young's moduli of soft layer ahead of the fracture on the fracture propagation by numerical (boundary-element method) modelling of two-layer geometries/systems. The final goal was to quantify a minimum critical thickness unit in which fewer fractures can propagate through this thickness threshold.

Results show that the decrease of tensile stress in welded-contact models with hydrofractures and tensile fractures is more regular than in weak-contact models. Additionally, more tensile stress reaches the surface of the welded-contact model when the layer ahead of a hydrofracture is thin and stiff compared to thin and soft. 
The weak-contact models show that different Young's moduli in moderately thick B layers do not affect the maximum tensile stress or the decrease of tensile stress between contacts and model surfaces. We determined a minimum critical thickness unit in which fewer fractures can propagate through this thickness threshold under different loading conditions (hydrofractures and tensile fractures). In the welded-contact model with hydrofracture conditions, layer B thickness of 20 units prevents the fracture propagation, whereas in models with tensile fractures the thickness threshold lies at 30 thickness units due to different traction values hydrofracture (10 $\mathrm{MPa})$ and tensile fracture (5 $\mathrm{MPa})$. Both thickness thresholds (thickness unit 20 for hydrofractures and 30 for tensile fractures) are comparable with the weak-contact models. Weak-contact models show additionally the changing effect of Young's moduli below the thickness threshold on the concentration of the maximum tensile stress between lithological contact and model surface.

The characterisation and quantification of fracture networks in layered rock is still a not completely solved problem because of heterogeneities. This quantification of critical marl thicknesses and other stress barriers can be used to improve predictions of fracture networks in layered rocks. 


\subsection{Appendix}

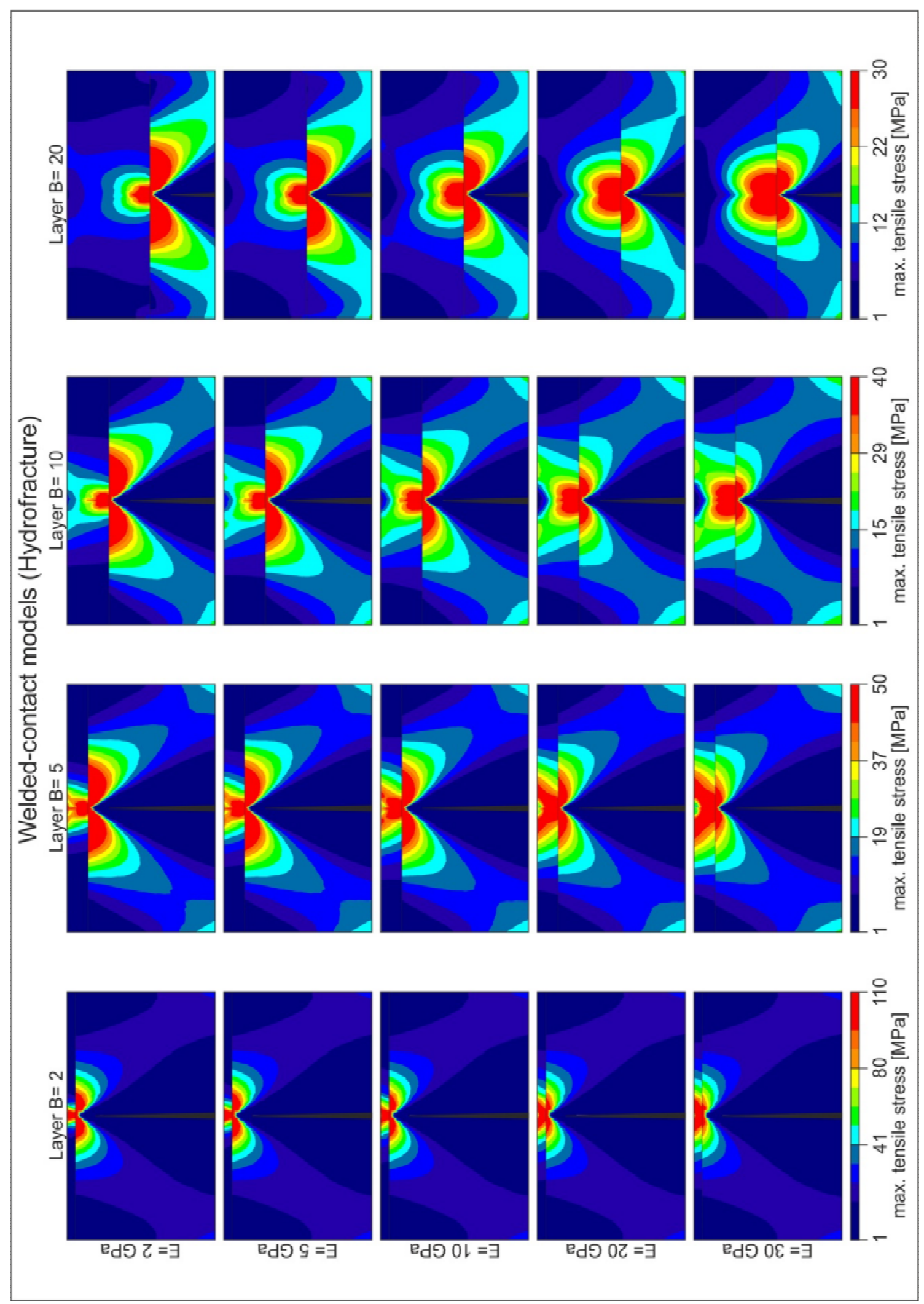

Figure 10.A: Selected diagrams showing the welded-contact models (thickness units 02, 05, $10,20)$ with tensile stress concentrations around hydrofractures in layer $\mathrm{A}(\mathrm{E}=40 \mathrm{GPa})$ and layer $\mathrm{B}(\mathrm{E}=02,05,10,20,30 \mathrm{GPa})$. Please observe that the colour scale is differently chosen for different layer $\mathrm{B}$ thicknesses. 


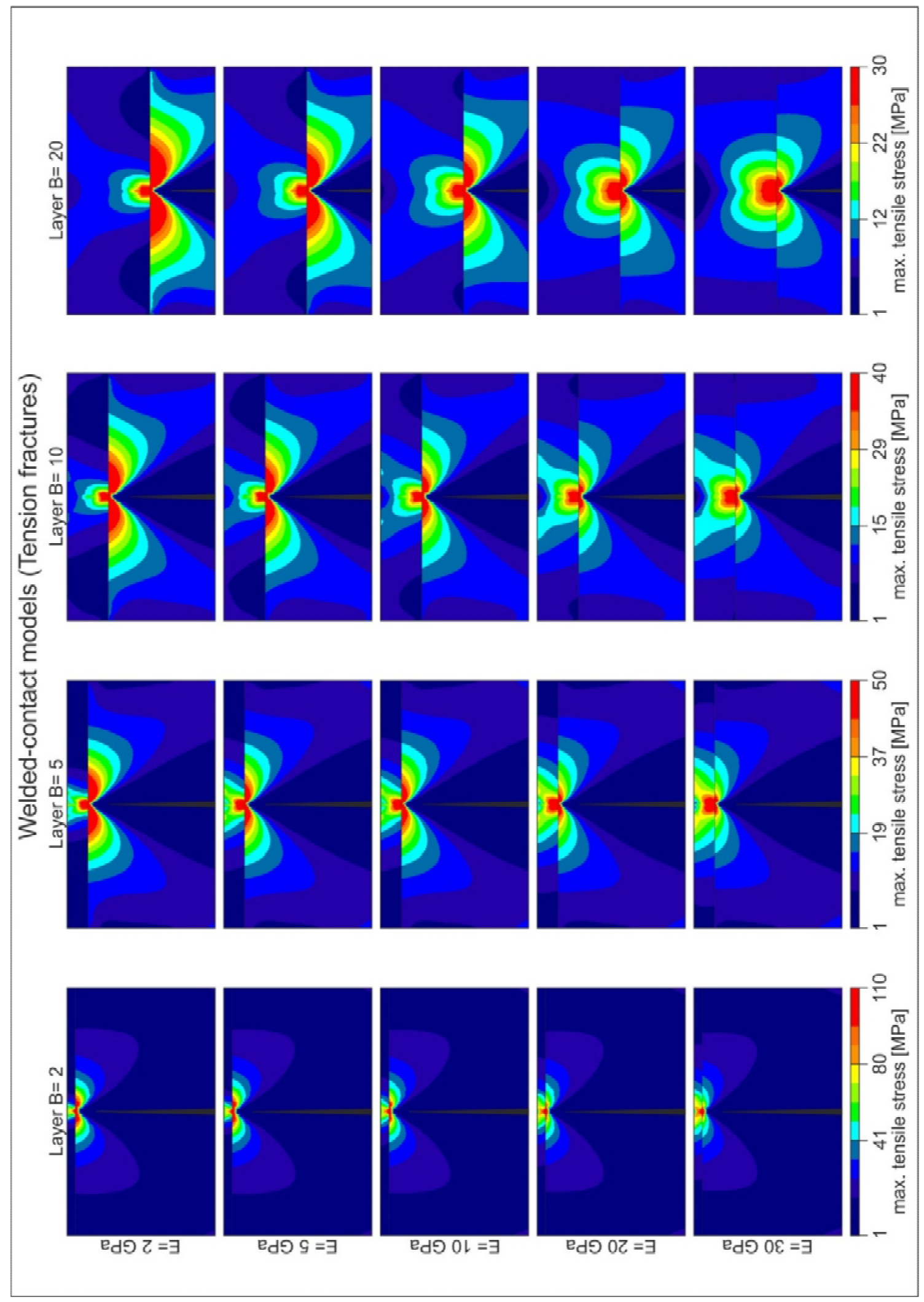

Figure 10.B: Selected diagrams showing the welded-contact models (thickness units 02, 05, $10,20)$ with tensile stress concentrations around tensile fractures in layer A (E = 40 GPa) and layer $\mathrm{B}(\mathrm{E}=02,05,10,20,30 \mathrm{GPa})$. Please observe that the colour scale is differently chosen for different layer B thicknesses. 


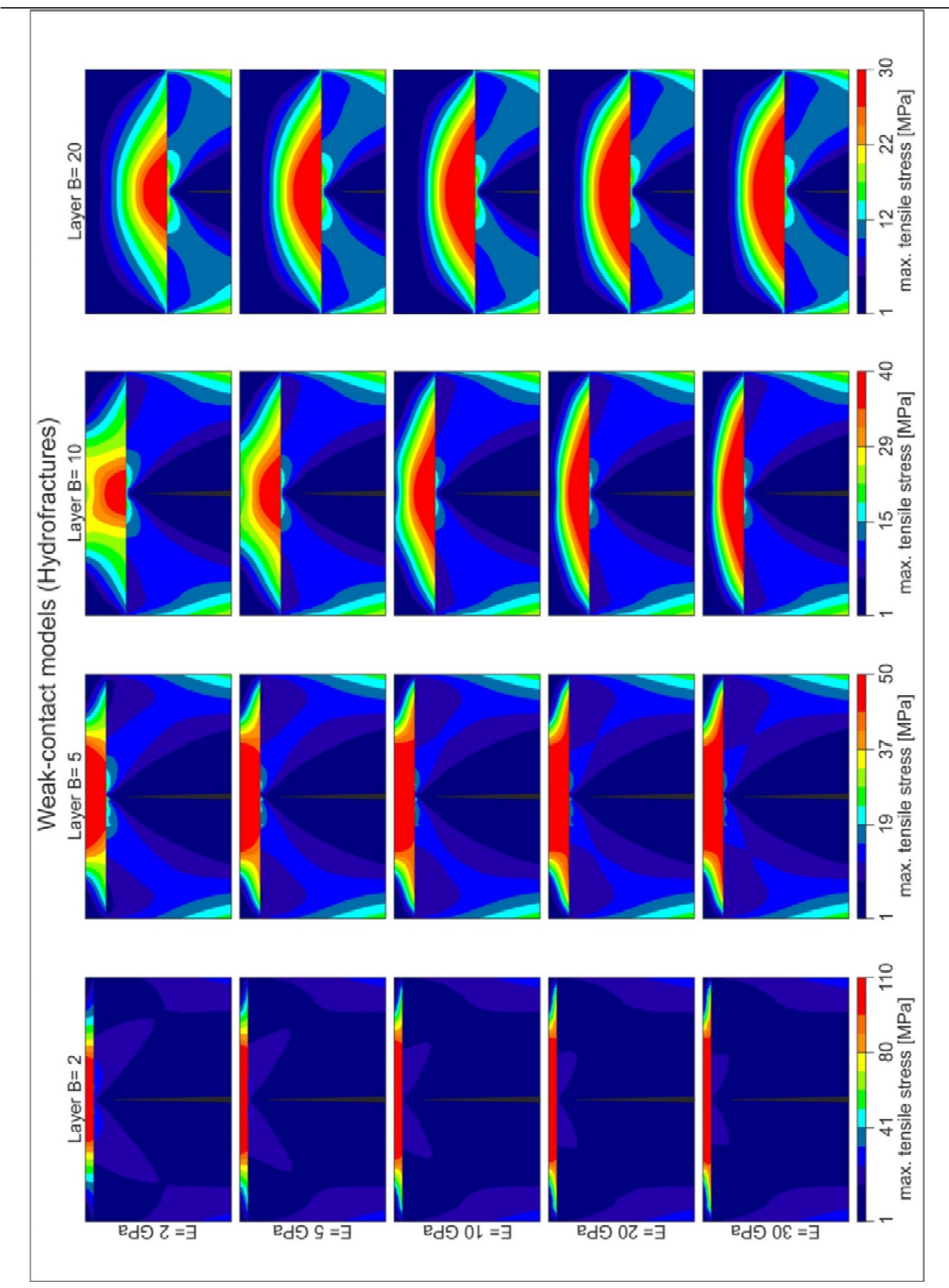

Figure 10.C: Selected diagrams showing the weak-contact models (thickness units 02, 05, 10, 20) with tensile stress concentrations around hydrofractures in layer $A(E=40 \mathrm{GPa})$ and layer $\mathrm{B}(\mathrm{E}=02,05,10,20,30 \mathrm{GPa})$. Please observe that the colour scale is differently chosen for different layer B thicknesses. 


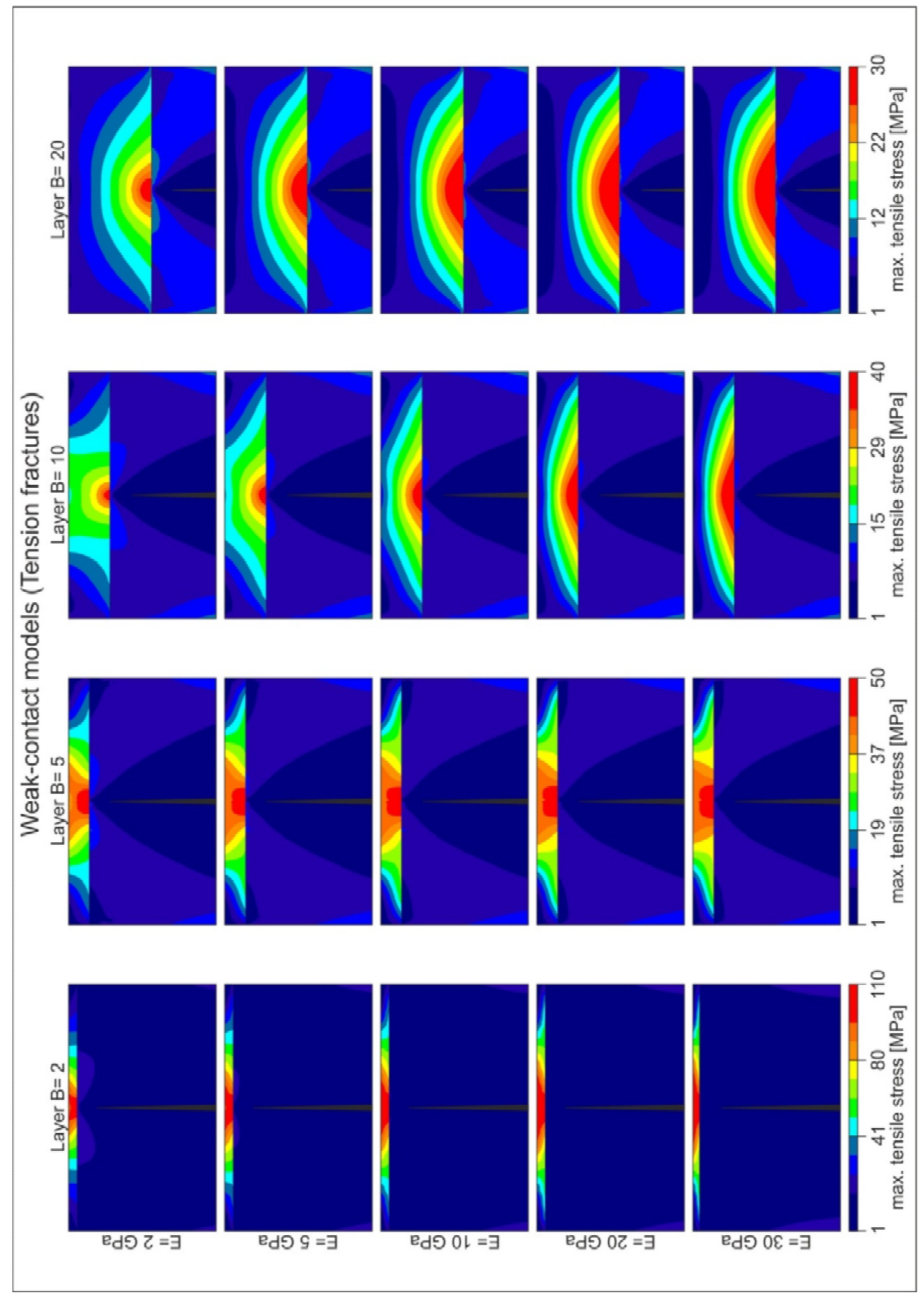

Figure 10.D: Selected diagrams showing the weak-contact models (thickness units 02, 05, 10, $20)$ with tensile stress concentrations around tensile fractures in layer $A(E=40 \mathrm{GPa})$ and layer $\mathrm{B}(\mathrm{E}=02,05,10,20,30 \mathrm{GPa})$. Please observe that the colour scale is differently chosen for different layer B thicknesses. 


\section{References}

Afşar F., Westphal H., Philipp S.L. (2014) How facies and diagenesis affect fracturing of limestone beds and reservoir permeability in limestone-marl alternations. Marine and Petroleum Geology, 57, 418-432.

Aguilera R. (2000) Well test analysis of multi-layered naturally fractured reservoirs. Journal of Canadian Petroleum Technology, 39, 31-37.

Aydin A. (2000) Fractures, faults, and hydrocarbon entrapment, migration and flow. Marine and Petroleum Geology, 17, 797-814.

Brenner S.L. (2003) Field studies and models of hydrofractures in heterogeneous reservoirs. $\mathrm{PhD}$ thesis. University of Bergen, Bergen, Norway.

Dvorkin J., Walls J.D., Mavko G. (2001) Rock Physics of Marls. Society of Exploration Geophysicists. SEG Expanded Abstracts, 1784-1787.

Gudmundsson A., Brenner S.L. (2001) How hydrofractures become arrested. Terra Nova, 13, 456-462.

Heuze F.E. (1980) Scale effects in the determination of rock mass strength and deformability. Rock mechanics, 12, 167-192.

Hobbs D.W. (1967) The formation of tension joints in sedimentary rocks: An Explanation. Geological Magazine, 104, 550-556.

Hobbs P. R. N., Entwisle D. C., Northmore K. J., Sumbler M. G., Jones L. D., Kemp S., Self S., Barron M., Meakin J. L. (2012) Engineering geology of British rocks and soils: Lias Group, British Geological Survey.

Mandl G., Harkness R.M. (1987) Hydrocarbon migration by hydraulic fracturing. In: Jones M.E., Preston R.M.E. (Eds.) Deformation of Sediments and Sedimentary Rocks. Geological Society of London, Special Publication 29, pp. 39-53.

Nunn J.A., Meulbroek P. (2002) Kilometer-scale upward migration of hydrocarbons in geopressured sediments by buoyancy-driven propagation of methane filled fractures. American Association of Petroleum Geologists Bulletin, 86, 907-918.

Odling N.E., Gillespie P., Bourgine B., Castaing C., Chilés J.-P., Christensen N.P., Fillion E., Genter A., Olsen C., Thrane L., Trice R., Aarseth E., Walsh J.J., Watterson J. (1999) Variations in fracture system geometry and their implications for fluid flow in fractured hydrocarbon reservoirs. Petroleum Geoscience, 5, 373-384.

Philipp S.L., Afşar F., Gudmundsson A. (2013) Effects of mechanical layering on hydrofracture emplacement and fluid transport in reservoirs. Frontiers in Earth Science, 1, 1-19.

Price N.J. (1966) Fault and Joint Development in Brittle and Semi-Brittle Rock. Pergamon Press, London.

Reeves G.M., Sims I., Cripps J.C. (2006) Clay Materials used in Construction. The geological Society of London. 


\section{-Chapter 11-}

\section{Conclusions and perspectives}

Many reservoirs for petroleum, natural gas, ground or geothermal water are layered naturally fractured reservoirs. Provided that fractures are well interconnected and the fracture network reaches the percolation threshold (cf. Stauffer and Aharônî, 1994), the networks are very efficient paths for the migration of fluids in such reservoirs (cf. Nelson, 1985; Mandl and Harkness, 1987; Aydin, 2000; Nunn and Meulbroek, 2002). However, in particular in layered rocks such as limestone-marl alternations the fracture distribution and fracture-associated permeability varies considerably between distinct layers due to the change of mechanical properties between these layers ('mechanical layering'; Gudmundsson and Brenner, 2001; Brenner, 2003). For instance, most fractures in layered rocks tend to be more confined to individual layers (Odling et al., 1999), but several layers (i.e. meter scale) can mainly comprise non-stratabound fractures (i.e. fractures are vertically persistent over several layers; Odling et al., 1999) and thus act mechanically as one single unit ('mechanical unit'; Gudmundsson, 2011). Therefore, for better prediction of fracture-associated permeability in such heterogeneous rocks, the characterisation and quantification of fracture networks are crucial, in order to generate better fluid flow models of layered reservoirs.

The main aim of the doctoral thesis is to assess the impact of sedimentological and diagenetic features and petrophysical properties on the fracture distribution (fracture orientation, density, spacing and height) and vertical fracture propagation in layered rocks. And consequently, to define mechanical units, therefore limestone-marl alternations of the Jurassic Blue Lias Formation (Bristol Channel Basin, United Kingdom) were used. For this study six sections of limestone-marl alternations showing strong morphological variations (e.g. from limestonedominated to marl-dominated) on very regional scale were investigated. Quantitative fracture data with sedimentological (thin section, SEM and CNS analyses) and petrophysical data (tensile and compressive strength-, hardness- and porosity-measurements) were combined. More than 4000 fractures were traced over several layers using a modified scan-line method (i.e. a combination of scan-line and window sampling). In addition to the fracture persistence (i.e. fracture height), determining the vertical extension through several layers (stratabound vs. non-stratabound fractures), further geometric fracture parameters such as the fracture 
orientation (strike and dip), fracture spacing in individual layers, commonly defined as the horizontal distance between two adjacent fractures (e.g. Narr and Suppe, 1991), and fracture density (number of fractures per metre) were acquired.

The presence of oil in shale beds (in Kilve, Somerset, Harvey and Gray, 2011) and the strong morphological variations of these alternations make the Blue Lias Formation an interesting outcrop analogue for studying fracture networks. Since the characterisation and quantification of fracture networks in such heterogeneous rocks is still a critical and not completely solved problem for outcrop analogue studies, following research questions could be answered:

1. How does the fracture distribution vary depending on the planarity of bedding planes and lateral variations in bed thicknesses of limestone beds?

It is well established that the spacing of tension fracture increases and the fracture density decreases with increasing bed thicknesses. This study revealed, however, that in the respective beds of these alternations this relationship is only limitedly applicable and only applies for beds with laterally planar surfaces (i.e. well-bedded limestones). Even in beds with the same thickness the fracture spacing varies significantly in beds with irregular surfaces (i.e. semi-nodular limestones). That means fractures measured over $15 \mathrm{~m}$ long beds are unregularly spaced in semi-nodular limestones and regularly spaced in wellbedded limestones. Fracture density varies significantly despite similar bed thicknesses. That is, well-bedded limestones with thicknesses between 5 to $20 \mathrm{~cm}$ show higher fracture densities than semi-nodular limestones, indicating that both lithologies must be distinguished. Furthermore, well-bedded limestones in the successions are generally characterised by higher percentages of stratabound fractures (57\%), while semi-nodular limestones show higher percentages of non-stratabound fractures $(67 \%)$. The planarity of bedding planes is directly related to the facies (trace fossils) and diagenesis of limestone-marl alternations (nodularity) and has consequences on the connectivity of fracture networks in layered rocks.

Further investigations concerning the quantification of bedding plane irregularities should focus on calculation of the sinuosity of bedding planes which is commonly used in describing the sinuosity of meandering rivers. This approach can be applied to define a threshold of bedding plane's sinuosity in which fractures are more regularly spaced. In the course of this, numerical three-layer models (BEASY Software) were run, in which a wellbedded limestone bed intercalated in marls was generated. After each model run the 
limestone bed was getting thinner at a certain area until two limestone nodules were left. Changes of the stress field in this progressively thinning limestone need to be analysed and evaluated.

2. How do different stress barriers affect vertical fracture propagation and reservoir permeability in limestone-marl alternations?

The aim of this study is to evaluate the impact of different stress barriers, such as lithological contact, layer thickness and heterogeneity, based on vertical fracture terminations, to quantify mechanical interfaces (some lithological contacts prevent the fracture propagation and some not), mechanical buffers (depending on the thickness and heterogeneities of marls).

The results show that stress barriers are not only related to (1) the contrasts in mechanical rock properties but also to (2) lithological contacts, (3) marl thicknesses and (4) heterogeneities in marls. Since not all lithological contacts prevent fracture propagation in layered rocks, the term 'stress barrier' was only used in this doctoral project for contacts at which $50 \%$ of the fractures terminate ( 'mechanical interfaces'). Most lithological contacts promote fracture terminations $(70 \%)$ and are thus mechanical interfaces. In addition thick marl layers $(>0.20 \mathrm{~m})$ bounded by mechanical interfaces and less than $50 \%$ nonstratabound fractures are defined as 'mechanical buffers'. Heterogeneities in marls, such as deformed bioturbation tubes (diagenetic pseudolamination), are common within these 'mechanical buffers' which additionally inhibit vertical fracture propagation. The findings demonstrate that layer characteristics (e.g. lithological contacts, thickness and heterogeneities) are highly variable in different variations of limestone-marl alternations and consequently crucially affect vertical fracture propagation.

Numerical models (BEASY Software) were run and evaluated (see chapter 10 for details), in which the termination of hydrofractures and tensile fractures at weak or welded limestone-marl contacts (mechanical interfaces vs. lithological contacts only) were simulated. For a better definition of mechanical units in such heterogeneous rocks, units of several layers (e.g. three limestone beds interbedded in marl layers) with changing marl thicknesses could be modelled.

3. Do diagenetic features from metre to micrometre scale affect the vertical fracture propagation in limestone-marl alternations? 
Additional petrographic analyses on the micrometre scale using scanning electron microscopy were conducted on three sections in close vicinity $(<500 \mathrm{~m}$ linear distance; NP1-3 in Wales). Despite the close proximity of these subsections and relative contemporaneous time of deposition, all three subsections reveal different sedimentological and diagenetic features on metre to micrometre scales (from early lithified to physically compacted) and are characterised by dissimilar patterns of fracture extension (e.g. percentages of stratabound vs non-stratabound fractures) within limestones and marls. The quantity of fractures terminating at or crossings through lithological contacts is different as well. Through differentiation of an almost homogenous mud sediment after deposition, through dissolution of $\mathrm{CaCO}_{3}$ in carbonate-poor interlayers and subsequent re-precipitation in layers initially enriched in carbonates ('differential diagenesis'; Ricken, 1986), the lithological contacts in such successions are more gradual due to the migration of $\mathrm{CaCO}_{3}$. If in addition the contrast of $\mathrm{CaCO}_{3}$-contents between limestones and marls is low and the lithological contact is welded, the diagenetically influenced successions can be defined as mechanical units which promote fracture propagation.

Nevertheless, based on the resulting scanning electron microscopic observations further questions arise. For example, observations of diagenetic features were made at metre scale, while at micrometre scale characteristics are absent. This contradictory observation is questionable and can be attributed to the limitation of sampling in these successions, due to the fragility of some marls sampling, however, was biased towards limestones. A further example for an incomprehensible observation is that neither faecal pellets nor coccolithophorids or other primary producers (e.g. dinoflagellates, diatoms) which commonly are assumed sources of the carbonate mud (Weedon, 1986) were observed under SEM. This observation raises further questions about the origin of these alternations. Future sampling of each limestone and marl layer could breakdown the questions.

4. How does mechanical layering affect hydrofracture emplacement and fluid transport in $\underline{\text { layered reservoirs? }}$

A hydrofracture is a fracture partly or wholly generated by internal fluid pressure. In this study the effects of mechanical layering in fluid reservoirs on the emplacement of hydrofractures and thus their ability to transport fluids were explored. In particular, models 
on fluid overpressures of hydrofractures, and crack-tip tensile stresses were presented and mechanical layering in reservoirs and its effects on hydrofracture emplacement were discussed. Additionally, field examples of hydrofractures affected by mechanical layering were compared with numerical models.

Hydrofractures indicate past fluid flow and the density increases on approaching the fault core and lead to an enhanced permeability (Caine et al., 1996; Sibson, 1996; Caine and Forster, 1999; Sibson, 2000; Faulkner et al., 2010; Gudmundsson et al., 2010; Agosta et al., 2012; Philipp, 2012; Reyer et al., 2012). Therefore, parameters of mineralised fractures (orientation, density, aperture, connectivity, vertical extension) within the two units (fault core, damage zone) of a fault zone were measured in detail and could be analysed further.

\section{How do lithological contacts and layer thicknesses prevent fracture propagation?}

Aim of this study is to evaluate the impact of different lithological contacts (welded or weak contact), layer thicknesses and contrast of Young's moduli on the fracture propagation by numerical modelling with on the boundary-element method (BEM) the termination of hydro- and tensile fractures at weak and welded lithological contacts. For the model parameters field and laboratory data published in Afşar et al. 2014 (see chapter 6 for details) were used.

A minimum critical thickness unit in which less fractures propagate through the layer under different loading conditions (hydrofractures and tensile fractures) was determined. E.g., layer thicknesses of 20 prevent the fracture propagation in welded-contact models under hydrofracture conditions. However, in models with tensile fractures the thickness threshold lies at 30 thickness units. Both thickness thresholds (thickness unit 20 for hydrofractures and 30 for tensile fractures) are comparable with those in weak-contact models. These models, however, show a changing effect of Young's moduli below the thickness thresholds on the maximum tensile stress ratio between lithological contacts and model surfaces.

\section{$\underline{\text { Relation between sedimentology, diagenesis and fracturing in field data and models }}$}

The overall characteristics of beds, being the product of sedimentary and diagenetic processes, especially the planarity of bedding planes, which is directly related to the facies (trace fossils) and diagenesis of limestone-marl alternations (nodularity), affect predominantly the fracture distribution in layered rocks. Concerning the fracture distribution and propagation 
in layered rocks, this study shows that the fracture distribution varies considerably and thus planar bedding planes (well-bedded limestones) and beds with bedding plane irregularities (semi-nodular limestones) must be distinguished. Semi-nodular limestones show higher percentages of non-stratabound fractures, especially these limestones promote the connectivity of fracture networks. The study demonstrates also that layer characteristics (e.g. marl heterogeneities, lithological contacts and marl thicknesses) are highly variable in different variations of limestone-marl alternations and may act as stress barriers (i.e. stress barriers prevent the vertical fracture propagation). Through differential compaction during early diagenesis, for example, marls often contains strong deformed bioturbation tubes (diagenetic pseudolamination) which mechanically have the same effect on the vertical fracture propagation as 'true' lamination. Limestone beds also contain undeformed bioturbation tubes in the centre part, whereas the bottom and top of the bed contain deformed bioturbation tubes, continuing into the adjacent marls. Since the complete compacted area below and above the limestone-marl contact prevent the fracture propagation through these contacts, this compacted area may act as a stress barrier zone with the result that many fractures are confined to the undeformed centres of the limestone beds. Field data show that less than 10 fractures propagate through $>0.2 \mathrm{~m}$ thick marl layers. This is in accordance with in this study generated numerical models, in which minimum critical thickness units of 20 , in which under hydrofracture conditions less fractures propagate through the layer were determined.

The characterisation and quantification of fracture networks in layered rock is still a critical and not completely solved problem for outcrop analogue studies due to lithological heterogeneities. Especially the knowledge about the effects of small scaled lithological heterogeneities (e.g. deformed bioturbation tubes) or the effects of bedding plane irregularities on fracture distribution and propagation is limiting. Therefore the findings of the effects of bedding plane irregularities on the fracture distribution are not only important for a better prediction of fracture distributions in single beds but also the classification of different layer characteristics and the identification of mechanical unit are crucial to improve the prediction of fracture networks in the entire layered rock. This thesis exemplifies how high resolution data (fracture measurements from millimetre to metre scale) from outcrop analogues can through be used to make predictions of fracture networks in limestone-marl alternations applicable for better fluid flow models 


\section{-References-}

Please note that this list refers to Chapters 1-5 and 11. References which are solely cited in the articles (Chapters 6-10) are displayed at the end of the respective chapter.

Afşar F., Westphal H., Philipp S.L. (2014) How facies and diagenesis affect fracturing of limestone beds and reservoir permeability in limestone-marl alternations. Marine and Petroleum Geology, 57, 418-432.

Adler P.M., Thovert J.-F., Mourzenko V.V. (2012) Fractured Porous Media. Oxford University Press, Oxford.

Ager D.V. (1974) The Jurassic Period in Wales. In: Owen T.R. (Eds.) The Upper Palaeozoic and PostPalaeozoic Rocks of Wales. University of Wales Press, Cardiff, pp. 232-339.

Agosta F., Ruano P., Rustichelli A., Tondi E., Galindo-Zaldívar J., Sanz de Galdeano C. (2012) Inner structure and deformation mechanisms of normal faults in conglomerates and carbonate grainstones (Granada Basin, Betic Cordillera, Spain): Inferences on fault permeability. Journal of Structural Geology, 45, 4-20.

Aguilera R. (1995) Naturally Fractured Reservoirs. Second ed., PennWell Publishing Company, Tulsa, Oklahoma.

Aydin A. (2000) Fractures, faults, and hydrocarbon entrapment, migration and flow. Marine and Petroleum Geology, 17, 797-814.

Bai T., Pollard D.D., Gao H. (2000) Explanation for fracture spacing in layered materials. Nature, 403, 753-756.

Bathurst R.G.C. (1971) Carbonate Sediments and Their Diagenesis. Elsevier Amsterdam, Developments in Sedimentology 12, pp. 1-620.

Becker, A., Gross, M.R. (1996) Mechanism for joint saturation in mechanically layered rocks: an example from southern Israel. Tectonophysics, 257, 223-237.

Belayneh M., Cosgrove J.W. (2010) Hybrid veins from the southern margin of the Bristol Channel Basin, UK. Journal of Structural Geology, 32, 192-201.

Bell F.G. (2000) Engineering properties of soils and rocks. Fourth ed., Blackwell, Oxford.

Berkowitz B. (2002) Characterizing flow and transport in fractured geological media: A review. Advances in Water Resources, 25, 861-884.

Biot M.A., Medlin W.L., Masse L. (1983) Fracture penetration through an interface. Society of Petroleum Engineers Journal, 23, 857-869.

Bloos G., Page K.N. (2002) Global statotype section and point for base of the Sinemurian Stage (Lower Jurassic). Episodes, 25, 22-28.

Bogdanov A.A. (1947) The intensity of cleavage as related to the thickness of beds. Soviet Geology, 16, 102-104 (cited by Ortega et al., 2006).

Bons P.D. (2001) The formation of large quartz veins by rapid ascent of fluids in mobile hydrofractures. Tectonophysics, 336, 1-17.

Bons P.D., Elburg M.A., Gomez-Rivas E. (2012) A review of the formation of tectonic veins and their microstructures. Journal of Structural Geology, 43, 33-62.

Boro H., Bertotti G., Hardebol N.J. (2013) Distributed fracturing affecting isolated carbonate platforms, the Latemar platform natural laboratory (Dolomites, North Italy). Marine and Petroleum Geology, 40, 69-84.

Brenchley P.J., Rawson P.F. (2006) The Geology of England and Wales. Second ed. Journal of the Geological Society, London.

Brenner S.L. (2003) Field studies and models of hydrofractures in heterogeneous reservoirs. Ph.D. thesis. University of Bergen, Bergen, Norway.

Brenner S.L., Gudmundsson A. (2004) Arrest and aperture variation of hydrofractures in layered reservoirs. In: Cosgrove J.W., Engelder T. (Eds.) The Initiation, Propagation, and Arrest of Joints and Other Fractures. Geological Society London, Special Publications, 231, pp. 117128. 
Brooks M., Trayner P.M., Trimble T.J. (1988) Mesozoic reactivation of Variscan thrusting in the Bristol Channel area, UK. Journal of the Geological Society, 145, 439-444.

Caine J.S., Evans J.P., Forster C.B. (1996) Fault zone architecture and permeability structure. Geology, 24, 1025-1028.

Caine J.S., Forster C.B. (1999) Fault zone architecture and fluid flow: insights from field data and numerical modeling. In: Haneberg W.C., Mozley P.S., Moore J.C., Goodwin L.B. (Eds.) Faults and Sub-surface Fluid Flow in the Shallow Crust. AGU Geophysical Monograph, 113, 101-127.

Cope J.C.W. (2006) Jurassic: the returning seas. In: Brenchley P.J., Rawson P.F. (Eds.) The Geology of England and Wales. Second ed., Journal of the Geological Society London, pp. 325-363.

Cox B.M., Sumbler M.G., Ivimey-Cook H.C. (1999) A Formational Framework for the Lower Jurassic of England and Wales (Onshore Area). British Geological Survey Research Report, $\mathrm{RR} / 99 / 01$.

Dart C.J., McClay K., Hollings P.N. (1995) 3D analysis of inverted extensional fault systems, southern Bristol Channel Basin, UK. In: Buchanan J.G., Buchanan P.G. (Eds.) Basin Inversion. Geological Society London, Special Publications, 88, pp. 393-413.

Davis P.M. (1983) Surface deformation associated with a dipping hydrofracture. Journal of Geophysical Research, 88, 5826-5834.

Dietrich P., Helmig R., Sauter M., Hötzl H., Köngeter J., Teutsch G. (2005) Flow and Transport in Fractured Porous Media. Springer, Berlin.

Dresen G., Stephansson O., Zang A. (2006) Rock damage and fluid transport, part I. Pure and Applied Geophysics, 163, 1-278.

Dunham R.J. (1962) Classification of carbonate rocks according to depositional texture. In: Ham W. E. (Eds.) Classification of Carbonate Rocks. American Association of Petroleum Geologists Memoir, pp. 108-121.

Economides M.J., Nolte K.G. (2000) Reservoir Stimulation $3^{\text {rd }}$ ed. Wiley and Sons Ltd., United Kingdom.

Einsele G. (1982) Limestone-marl cycles (periodites): Diagnosis, significance, causes- a review. In: Einsele G., Seilacher A. (Eds.) Cyclic and Event Stratification. Springer, Berlin Heidelberg New York, pp 8-53.

Einsele G., Ricken W., Seilacher A. (1991) Cycles and Events in Stratigraphy. Springer-Verlag, Berlin Heidelberg New York.

Erdogan F. (1972) Fracture problems in composite materials. Engineering Fracture Mechanics, 4, 811-840.

Engelder T., Peacock D.C.P. (2001) Joint development normal to regional compression during flexural-flow folding: the Lilstock buttress anticline, Somerset, England. Journal of Structural Geology, 23, 259-277.

Faulkner D.R., Jackson C.A.L., Lunn R.J., Schlische R.W., Shipton Z.K., Wibberley C.A.J., Withjack M.O., (2010) A review of recent developments concerning the structure, mechanics and fluid flow properties of fault zones. Journal of Structural Geology, 32, 1557-1575.

Fletcher C.J.N. (1988) Tidal erosion, solution cavities and exhalative mineralization associated with the Jurassic unconformity at Ogmore, South Glamorgan. Proceedings of the Geologists' Association, 99, 1-4.

Flügel E. (2010) Microfacies of Carbonate Rocks Analysis, Interpretation and Application. Second ed., with a contribution by Axel Munnecke. Springer, Heidelberg.

Fossen H. (2010) Structural Geology. Cambridge University Press, Cambridge.

Gassiat C., Gleeson T., Lefebvre R., McKenzie J. (2013) Hydraulic fracturing in faulted sedimentary basins: Numerical simulation of potential contamination of shallow aquifers over long time scales. Water Resources Research, 49, 8310-8327.

George N.T. (1970) British Regional Geology. South Wales. Rev. third ed., Stationery Office Books.

Glen R.A., Hancock P.L., Whittaker A. (2005) Basin inversion by distributed deformation: the southern margin of the Bristol Channel Basin, England. Journal of Structural Geology, 27, 2113-2134.

Gross M.R. (1993) The origin and spacing of cross joints: Examples from the Monterey Formation, Santa-Barbara Coastline, California. Journal of Structural Geology, 15, 737-751. 
Gudmundsson A. (2006) How local stresses control magma-chamber ruptures, dyke injections, and eruptions in composite volcanoes. Earth-Science Reviews, 79, 1-31.

Gudmundsson A. (2011) Rock Fractures in Geological Processes. Cambridge University Press, Cambridge.

Gudmundsson A., Brenner S.L. (2001) How hydrofractures become arrested. Terra Nova, 13, 456462.

Gudmundsson A., Fjeldskaar I., Brenner S.L. (2002) Propagation pathways and fluid transport of hydrofractures in jointed and layered rocks in geothermal fields. Journal of Volcanology and Geothermal Research, 116, 257-278.

Gudmundsson A., Simmenes T.H., Larsen B., Philipp S.L. (2010) Effects of internal structure and local stresses on fracture propagation, deflection, and arrest in fault zones. Journal of Structural Geology, 32, 1643-1655.

Gudmundsson A., Kusumoto S., Simmenes T.H., Philipp S.L., Larsen B., Lotveit I.F. (2012) Effects of overpressure variations on fracture apertures and fluid transport. Tectonophysics, 581, 220230.

Gundersen E., Flekkoy E.G., Bjorlykke K., Feder J., Jamtveit B. (2011) Fracture spacing during hydro-fracturing of cap-rocks. Geofluids, 11, 280-293.

Hallam A. (1960) A sedimentary and faunal study of the Blue Lias of Dorset and Glamorgan. Philosophical Transactions of the Royal Society B, 243, 1-44.

Hallam A. (1986) Origin of Minor Limestone-Shale Cycles-Climatically Induced or Diagenetic. Geology, 14, 609-612.

Hancock P.L., Engelder T. (1989) Neotectonic Joints. Geological Society of American Bulletin, 101, 1197-1208.

Haq B.U., Hardenbol J., Vail,P.R. (1987) Chronology of fluctuating sea levels since the Triassic. Science, 235, 1156-1167.

Harvey T., Gray J. (2011) The Unconventional Hydrocarbon Resources of Britain's Onshore BasinsShale Gas. London, UK: Department of Energy and Climate Change.

Helgeson D.E., Aydin A. (1991) Characteristics of joint propagation across layer interfaces in sedimentary rocks. Journal of Structural Geology, 13, 897-911.

Hesselbo S.P., Robinson S.A., Surlyk F. (2004) Sea-level change and facies development across potential Triassic-Jurassic boundary horizons, SW Britain. Journal of the Geological Society of London, 161, 365-379.

Hobbs D.W. (1967) The formation of tension joints in sedimentary rocks: An Explanation. Geological Magazine, 104, 550-556.

Hoffmann S. (2006) Naturwerksteine Thailands: Lagerstättenerkundung und Bewertung, Ph.D. Thesis, Georg-August-Universität Göttingen, Göttingen.

Hudson J.A., Harrison J.P. (2000) Engineering Rock Mechanics. An introduction to the Principles. Pergamon Press, London.

ISRM (2007) The complete ISRM suggested methods for rock characterization, testing and monitoring: 1974-2006. Suggested methods prepared by the ISRM commission on testing methods. In: Ulusay R., Hudson J.A (Eds.) Compilation arranged by the ISRM Turkish National Group, International Society for Rock Mechanics, Ankara, Turkey.

Kamerling P. (1979) The geology and hydrocarbon habitat of the Bristol Channel Basin. Journal of Petroleum Geology, 2, 75-93.

Labaume P., Craw D., Lespinasse M., Muchez P. (2002) Tectonic processes and the flow of mineralising fluids. Tectonophysics, 348, 1-185.

Lachenbruch A. H. (1961) Depth and Spacing of Tension Cracks. Journal of Geophysical Research, 66, 4273-4292.

Ladeira F.L., Price N.J. (1981) Relationship between fracture spacing and bed thickness. Journal of Structural Geology, 3, 179-183.

Laubach S.E., Olson J.E., Gross M.R. (2009) Mechanical and fracture stratigraphy. American Association of Petroleum Geologists Bulletin, 93, 1413-1426.

Mandal N., Deb S.K., Khan D. (1994) Evidence for a non-linear relationship between fracture spacing and layer thickness. Journal of Structural Geology, 16, 1275-1281.

Mandl G. (2005) Rock joints: The mechanical genesis. Springer, Berlin. 
Mandl G., Harkness R.M. (1987) Hydrocarbon migration by hydraulic fracturing. In: Jones M.E., Preston R.M.E. (Eds.) Deformation of Sediments and Sedimentary Rocks. Geological Society of London, Special Publication 29, pp. 39-53.

Mastella L. (1972) Interdependence of joint density and thickness of layers in the Podhale Flysch. Bulletin de l'Académie Polonaise des Sciences, 20, 187-196.

Melim L.A., Westphal H., Swart P.K., Eberli G.P., Munnecke A. (2002) Questioning carbonate diagenetic paradigms: evidence from the Neogene of the Bahamas. Marine Geology, 185, $27-$ 53.

Meulenkamp F., Alvarez Grima M. (1999) Application of neural networks for the prediction of the unconfined compressive strength (UCS) from equotip hardness. International Journal of Rock Mechanics and Mining Science, 36, 29-39.

Moeck I., Kwiatek G., Zimmermann G. (2009) Slip tendency analysis, fault reactivation potential and induced seismicity in a deep geothermal reservoir, Journal of Structural Geology, 31, 11741182.

Munnecke A., Samtleben C. (1996) The formation of micritic limestones and the development of limestone-marl alternations in the Silurian of Gotland, Sweden. Facies, 34, 159-176.

Munnecke A., Westphal H. (2005) Variations in primary aragonite, calcite, and clay in fine-grained calcareous rhythmites of Cambrian to Jurassic age-an environmental archive? Facies, 51, 611626.

Munnecke A., Westphal H., Elrick M., Reijmer J.J.G. (2001) The mineralogical composition of precursor sediments of calcareous rhythmites: a new approach. International Journal of Earth Sciences, 90, 795-812.

Narr W., Suppe J. (1991) Joint spacing in sedimentary rocks. Journal of Structural Geology, 13, 10371048.

Nelson R.A. (1985) Geologic Analysis of Naturally Fractured Reservoirs. First ed., Gulf Publishing Company, Houston, Texas.

Nemčok M., Gayer R., Miliorizos M. (1995) Structural analysis of the inverted Bristol Channel Basin: Implications for the geometry and timing of fracture porosity. In: Buchanan J.G., Buchanan P.G. (Eds.) Basin Inversion. Geological Society London, Special Publications, 88, pp. 355392.

Neuzil C.E. (2003) Hydromechanical coupling in geologic processes. Hydrogeology Journal, 11, 41 83.

Norris D.K. (1966) The about mesoscopic fabric of rock masses about some Canadian coal mines. First ISRM Congress, International Society for Rock Mechanics, 1, 191-198.

Nunn J.A., Meulbroek P. (2002) Kilometer-scale upward migration of hydrocarbons in geopressured sediments by buoyancy-driven propagation of methane filled fractures. American Association of Petroleum Geologists Bulletin, 86, 907-918.

Odling N.E., Gillespie P., Bourgine B., Castaing C., Chilés J.-P., Christensen N.P., Fillion E., Genter A., Olsen C., Thrane L., Trice R., Aarseth E., Walsh J.J., Watterson J. (1999) Variations in fracture system geometry and their implications for fluid flow in fractured hydrocarbon reservoirs. Petroleum Geoscience, 5, 373-384.

Parrish J.T. (1993) Climate of the Supercontinent Pangea. Journal of Geology, 101, 251-233.

Pascal C., Angelier J., Cacas M.-C., Hancock P.L. (1997) Distribution of joints: Probabilistic modelling and case study near Cardiff (Wales, UK). Journal of Structural Geology, 19, 12731284.

Petit J.-P., Auzias V., Rawnsley K., Rives T. (1999) Development of joint sets in the vicinity of faults. In: Lehner F.K., Urai J.L. (Eds.) Aspects of Tectonic Faulting. Springer-Verlag, Berlin Heidelberg, pp. 167-183.

Philipp S.L. (2012) Fluid overpressure estimates from aspect ratios of mineral veins. Tectonophysics, 581, 35-47.

Philipp S.L., Afşar F., Gudmundsson A. (2013) Effects of mechanical layering on hydrofracture emplacement and fluid transport in reservoirs. Frontiers of Earth Science, 1, 1-19.

Priest S.D. (1992) Discontinuity Analysis for Rock Engineering. Chapman and Hall, London.

Priest, S.D. (2004) Determination of Discontinuity Size Distributions from Scanline Data. Rock Mechanics and Rock Engineering, 37, 347-368. 
Price N.J. (1966) Fault and Joint Development in Brittle and Semi-Brittle Rock. Pergamon Press, London.

Rawnsley K.D., Peacock D.C.P., Rives T., Petit J.-P. (1998) Joints in the Mesozoic sediments around the Bristol Channel Basin. Journal of Structural Geology, 20, 1641-1661.

Reinhardt E.G., Cavazza W., Patterson R.T., Blenkinsop J. (2000) Differential diagenesis of sedimentary components and the implication for strontium isotope analysis of carbonate rocks. Chemical Geology, 164, 331-343.

Reyer D., Bauer J.F., Philipp S.L. (2012) Fracture systems in normal fault zones crosscutting sedimentary rocks, Northwest German Basin. Journal of Structural Geology, 45, 38-51.

Ricken W. (1985) Diagenetische Bankung: Zementbilanz, Geochemie und Fazies von Kalk-MergelWechselfolgen. Dissertation.

Ricken W. (1986) Diagenetic Bedding. Lecture Notes in Earth Sciences, Springer-Verlag, Berlin, Heidelberg, New York, 6, 1-219.

Ricken W. (1987) The carbonate compaction law: a new tool. Sedimentology, 34, 571-584.

Rummel F. (1987) Fracture mechanics approach to hydraulic fracturing stress measurements. In: Atkinson B. (Eds.) Fracture Mechanics of Rock. Academic Press, London, pp. 217-239.

Sahimi M. (2011) Flow and Transport in Porous Media and Fractured Rock: From Classical Methods to Modern Approaches. Wiley, New York.

Sandberg P. A. (1983) An oscillating trend in Phanerozoic non-skeletal carbonate mineralogy. Nature, 305, 19-22.

Sandberg P. (1985) Nonskeletal aragonite and $\mathrm{pCO}_{2}$ in Phanerozoic and Proterozoic. In: Sundquist E., Broecker W. (Eds.) The Carbon Cycle and Atmospheric $\mathrm{CO}_{2}$ : Natural Variations, Archean to Present. American Geophysical Union Monograph, pp. 585-594.

Schön J.H. (2004) Physical Properties of Rocks: Fundamentals and Principles of Petrophysics. Second ed., Elsevier, London.

Schöpfer M.P.J., Arslan A., Walsh J.J., Childs C. (2011) Reconciliation of contrasting theories for fracture spacing in layered rocks. Journal of Structural Geology, 33, 551-565.

Schwarzacher W. (1975) Sedimentation models and quantitative stratigraphy. Developments in Sedimentology, 19, Elsevier.

Schwarzacher W. (1993) Cyclostratigraphy and the Milankovitch Theory. Elsevier, Amsterdam.

Seibold E. (1952) Chemische Untersuchungen zur Bankung im unteren Malm Schwabens. Neues Jahrbuch für Geologie und Paläontologie-Abhandlungen, 95, 337-370.

Sheppard T.H., Houghton R.D., Swan A.R.H. (2006) Bedding and pseudo-bedding in the early Jurassic of Glamorgan: deposition and diagenesis of the Blue Lias in South Wales. Proceedings of the Geologists' Association, 117, 249-264.

Sheppard T.H. (2006) Sequence architecture of ancient rocky shorelines and their response to sea-level change: an Early Jurassic example from South Wales, UK. Journal of the Geological Society London, 163, 595-606.

Sibson R.H. (1996) Structural permeability of fluid-driven fault-fracture meshes. Journal of Structural Geology, 18, 1031-1042.

Sibson R.H. (2000) Fluid involvement in normal faulting. Journal of Geodynamics, 29, 469-499.

Smith A.G., Smith D.G., Funnell B.M. (1994) Atlas of Mesozoic and Cenozoic Coastline. Cambridge University Press, Cambridge.

Sowers G. M. (1972) Theory of spacing of extension fracture. Engineering Geology Case Histories, 9 , 27-52

Stanley S.M., Hardie L.A. (1999) Hypercalcification: Paleontology links plate tectonics and geochemistry to sedimentology. Geological Society of America Today, 9, 1-7.

Stauffer D., Aharônî A. (1994) Introduction to Percolation Theory. Rev. second ed., Taylor \& Francis Ltd, London.

Stewart S.A., Ruffell A.H., Harvey M.J. (1997) Relationship between basement-linked and gravitydriven fault systems in the UKCS salt basins. Marine and Petroleum Geology, 14, 581-604.

Truemann A.E. (1922) The Liassic Rocks of Glamorgan. Proceedings of the Geologists' Association, 33, 245-284. 
Tappin D.R., Chadwick R.A., Jackson A.A., Wingfield R.T.R., Smith N.J.P. (1994) The Geology of Cardigan Bay and the Bristol Channel, United Kingdom Offshore Regional Report. British Geological Survey, London.

Vail P.R., Mitchum R.M., Thompson S. (1977) Seismic stratigraphy and global changes of sea level: Part 4. Global cycles of relative changes of sea level. Section 2. Application of seismic reflection configuration to stratigraphic interpretation. American Association of Petroleum Geologists Memoir, pp. 83-97.

Van Hoorn B. (1987) The South Celtic Sea/Bristol Channel Basin: Origin, deformation and inversion history. Tectonophysics, 137, 309-334.

Vigneresse J.L. (2001) Fluids and fractures in the lithosphere. Tectonophysics, 336, 1-244.

Warpinski N.R., Schmidt R.A., Northrop D.A. (1982) In-situ stress: The predominant influence on hydraulic fracture containment. Journal of Petroleum Technology, 34, 653-664.

Weedon G.P. (1986) Hemipelagic shelf sedimentation and climatic cycles: The basal Jurassic (Blue Lias) of South Britain. Earth and Planetary Science Letters, 76, 321-335.

Westphal H., Head M.J., Munnecke A. (2000) Differential diagenesis of rhythmic limestone alternations supported by palynological evidence. Journal of Sedimentary Research, 70, 715725 .

Westphal H., Munnecke A. (2003) Limestone-marl alternations: A warm-water phenomenon? Geology, 31, 263-266.

Westphal H., Munnecke A., Böhm F., Bornholdt S. (2008) Limestone-marl alternations in epeiric sea settings - witnesses of environmental changes, or of rhythmic diagenesis? In: Holmden C., Pratt B.R. (Eds.) Dynamics of Epeiric Seas: Sedimentological, Paleontological and Geochemical Perspectives. Geological Association of Canada Special Paper, pp. 1-20.

Whittaker A., Green G.W. (1983) Geology of the Country around Weston-super-Mare. Geological Survey of Great Britain, Institute of Geological Sciences, Her Majesty's Stationary Office, London.

Wignall P.B., Hallam A. (1991) Biofacies, stratigraphic distribution and depositional models of British onshore Jurassic Black shales. In: Tyson, R.V., Pearson, T.H. (Eds.) Modern and Ancient Continental Shelf Anoxia, Geological Society London, Special Publications, 58, pp. 291-309.

Wilson D., Davies J.R., Fletcher C.J.N., Smith M. (1990) Geology of the South Wales Coalfield, Part VI, the Country Around Bridgend. Second ed., British Geological Survey, London.

Woodcock N., Strachan R. (2002) Geological History of Britain and Ireland. Blackwell Publishing.

Wu H.Q., Pollard D.D. (1995) An experimental-study of the relationship between joint spacing and layer thickness. Journal of Structural Geology, 17, 887-905. 


\section{-Curriculum Vitae Filiz Afşar-}

\section{$\underline{\text { Personal data }}$}

Date of birth: 02.03.1984

Place of birth: Vorwerk (Germany)

\section{$\underline{\text { Academic education }}$}

07/2010-present Graduate student (PhD), Georg-August-University Göttingen, Germany.

PhD thesis: 'Fracture propagation and reservoir permeability in limestone-marl alternations of the Jurassic Blue Lias Formation (Bristol Channel Basin, UK)'.

Supervisors: Prof. Dr Sonja L. Philipp, Prof. Dr Hildegard Westphal.

$10 / 2007-05 / 2010$

MSc Geosciences, University of Bremen, Germany.

Master's thesis: 'Acoustic behaviour of mixed carbonate-siliciclastic rocks (Picún Leufú-Formation, Upper Jurassic/Lower Cretaceous, Neuquén basin, Argentina)' (written in German).

Supervisors: Prof. Dr Hildegard Westphal, Prof. Dr Gregor P. Eberli, Dr Klaas Verwer.

10/2004-10/2007 BSc Geosciences, University of Bremen, Germany.

Bachelor's thesis: 'Interaction between the generation and depth of magma chamber with morphology of volcanic cones; simulated with the discrete element method' (written in German).

Supervisors: Prof. Dr Katrin Huhn, PD Dr Andreas Klügel.

\section{Grants}

2013

Postgraduate grant, International Association of Sedimentologists (IAS), Postgraduate grant scheme ( $2^{\text {nd }}$ session).

Travel grants, Göttingen International (Georg-August-University Göttingen) and International Association of Sedimentologists (IAS).

\section{Publications}

$\underline{\text { Peer-review journals (corresponding author underlined) }}$

Afșar F., Westphal H., Philipp S.L. (under review) Effects of stress barriers on reservoir permeability in layered rocks: A case study of Blue Lias rhythms (Bristol Channel Basin, UK). American Association of Petroleum Geologists Bulletin.

Zeller M., Weger R.J., Verwer K., Afşar F., Giunta D.L., Eberli G.P., Massaferro J.L. (under review) Seismic expressions of Picún-Leufú - Vaca Muerta outcrops - Implications for seismic interpretation of mixed carbonate - siliciclastic systems. American Association of Petroleum Geologists Bulletin.

Afșar F., Westphal H., Philipp S.L. (2014) How facies and diagenesis affect fracturing of limestone beds and reservoir permeability in limestone-marl alternations. Marine and Petroleum Geology, 57, 418-432. 
Afșar F., Duda J.-P., Zeller M., Verwer K., Westphal H., Eberli G.P. (2014) First report of sponge rhaxes in the Picún Leufú Formation (Tithonian-Berriasian), Neuquén Basin, Argentina. In: Wiese F., Reich M., Arp G. (eds.): "Spongy, slimy, cosy \& more...". Commemorative volume in celebration of the 60th birthday of Professor Joachim Reitner. Göttingen Contributions to Geosciences, 77, 49-56.

Philipp S.L., Afşar F., Gudmundsson A. (2013) Effects of mechanical layering on hydrofracture emplacement and fluid transport in reservoirs. Frontiers in Earth Science, 1, 1-19.

\section{Extended abstracts and other publications}

Afşar F. (subm.) Scanning electron microscope analysis of a limestone-marl alternation: further insights into the effects of diagenesis on fracture propagation in layered rocks. IAS Postgraduate Grant Scheme Report, $2^{\text {nd }}$ Session 2013: 1-5.

Afşar F., Westphal H., Philipp S.L. (2013) Effects of facies and diagenesis on fracture propagation and reservoir permeability in limestone-marl alternations. In: Philipp, S.L., Acocella, V. (eds.): Rock fractures in Geological Processes, Abstracts of the Presentations of the Symposium, London, 26-27 November 2013: 27-31.

Verwer K., Eberli G.P., Afşar F. (2009) Petrophysical properties of mixed carbonatesiliciclastic rocks. Research program prospectus of Comparative Sedimentology Laboratory: 63-65.

\section{$\underline{\text { Relevant conference contributions (own presentations only) }}$}

Afşar F., Philipp S.L. (2014) Biased versus random samples of fracture measurements in limestone marl alternations. EGU General Assembly, Vienna, 27-02 May, Geophysical Research Abstracts 15, EGU2014-1192 [poster].

Afşar F., Westphal H., Philipp S.L. (2013) How bedding plane irregularities, facies and diagenesis influence fracture propagation and reservoir permeability in limestone-marl alternations. 30 ${ }^{\text {th }}$ IAS Meeting of Sedimentology, Manchester, 2-5 September 2013 [poster].

Afşar F., Westphal H., Philipp S.L. (2011) Influence of sedimentary facies and diagenesis on mechanical rock properties and the resulting fracture propagation in limestone-marl alternations (Jurassic Blue Lias Formation, Bristol Channel Basin, UK). 14th Bathurst Meeting of Carbonate Sedimentologists, Bristol [talk].

Afşar F., Verwer K., Zeller M., Eberli G.P., Westphal H. (2011) Influence of sedimentary facies and mineral composition on acoustic velocities of mixed carbonate-siliciclastic rocks (Picún Leufú-Formation, Neuquén Basin, Argentina). 14th Bathurst Meeting of Carbonate Sedimentologists, Bristol [poster].

Afşar F., Philipp S.L., Westphal H. (2011) Fracture propagation and reservoir permeability in limestone-marl alternations of the Jurassic Blue Lias Fm (Bristol Channel Basin, UK)a multidisciplinary approach. EGU General Assembly, Vienna, Geophysical Research Abstracts 13. EGU-2011-5672 [talk].

Afşar F., Westphal H., Philipp S.L. (2011) Influence of sedimentary facies on rock hardness in limestone-marl alternations of the Jurassic Blue Lias Formation (Bristol Channel Basin, UK). EGU General Assembly, Vienna, Geophysical Research Abstracts 13, EGU2011-5605 [poster]. 